\title{
Narrow Representation? The Impact of Implicitly and Explicitly Racial Issues on Opinion and Representation
}

\author{
Franchesca V. Nestor
}

Follow this and additional works at: https://researchrepository.wvu.edu/etd

\section{Recommended Citation}

Nestor, Franchesca V., "Narrow Representation? The Impact of Implicitly and Explicitly Racial Issues on Opinion and Representation" (2017). Graduate Theses, Dissertations, and Problem Reports. 6307. https://researchrepository.wvu.edu/etd/6307

This Dissertation is protected by copyright and/or related rights. It has been brought to you by the The Research Repository @ WVU with permission from the rights-holder(s). You are free to use this Dissertation in any way that is permitted by the copyright and related rights legislation that applies to your use. For other uses you must obtain permission from the rights-holder(s) directly, unless additional rights are indicated by a Creative Commons license in the record and/ or on the work itself. This Dissertation has been accepted for inclusion in WVU Graduate Theses, Dissertations, and Problem Reports collection by an authorized administrator of The Research Repository @ WVU. For more information, please contact researchrepository@mail.wvu.edu. 
Narrow Representation?

The Impact of Implicitly and Explicitly Racial Issues on Opinion and

Representation

\author{
Franchesca V. Nestor \\ Dissertation submitted \\ to the Eberly College of Arts and Sciences \\ at West Virginia University \\ in partial fulfillment of the requirements for the degree of \\ Doctor of Philosophy in \\ Political Science \\ Jason MacDonald, Ph.D., Chair \\ Jeffrey Worsham, Ph.D. \\ Matthew Jacobsmeier, Ph.D. \\ Rachael A. Woldoff, Ph.D. \\ Department of Political Science
}

\title{
Morgantown, West Virginia \\ 2017
}

Keywords: racialization, racial salience, implicitly racial, explicitly racial, racial and ethnic politics, Black opinion, Latino opinion, income and opinion, intersectionality

Copyright 2017 Franchesca V. Nestor 


\section{Abstract \\ Narrow Representation? The Impact of Implicitly and Explicitly Racial Issues on Opinion and Representation}

\section{Franchesca V. Nestor}

My dissertation combines knowledge from the opinion, racial and ethnic politics, and representation literatures to examine Black and Latino opinion and representation on racially salient issues. I theorize that representation of Blacks and Latinos is a "narrow" representation, much more in line with Black and Latino opinion on issues that are explicitly, rather than implicitly, racial. To test this theory, I build upon the literature by considering intersectional identity and multiple methods of representation. In Chapter 2, I examine two questions: when do income and racial group differences occur on racially salient issues, and if splits occur between respondents of higher and lower incomes according to the racialized nature of the issues, on which type of issues do government outputs respond better to either group? My approach extends Gilens's (2012) method for imputing opinion by income to racial groups. I find income can be an important driver of opinion for not only whites but also Blacks and Latinos. Government outputs on racially salient issues, however, do not seem to follow either Gilens's (2012) findings that high income opinion drives government, or Griffin and Newman's (2008) findings that African Americans experience better government representation on racially salient issues. Rather, Blacks' and Latinos' desire for change does not seem to drive government outputs on implicitly racial issues, and whites' desire for change does not seem to drive government outputs on explicitly racial issues. In Chapter 3, I move to consider descriptive representation and the effects of racially salient issues upon individual legislator responsiveness. Do African American and Latino legislators do a better job of representing low-income African Americans and low-income Latinos on two implicitly racial issues where their opinions are unique? I find that this is largely not the case, although Latino Republicans show some promise. In addition, a sponsorship analysis on both implicitly and explicitly racial issues shows that African American and Latino legislators are more active than other legislators in sponsoring legislation that supports low-income Black and Latino interests on immigration (an explicitly racial issue), but not different from other legislators in their sponsorship behavior for Iraq withdrawal (an implicitly racial issue). Moreover, chapter 3 reveals that large numbers of low-income Blacks and Latinos in districts have no bearing on the behavior of legislators in these analyses, including Black and Latino legislators. Finally, chapter 4 considers committee oversight, examining the influence of Black and Latino committee members, and of early 1990s redistricting, upon explicitly and implicitly racial oversight. Chapter 4 reveals a distinct difference after redistricting for implicitly racial issues, with the number of African American members heavily affecting such oversight after the $103^{\text {rd }}$ Congress. This project builds understanding of racial disadvantage, and how it occurs in government. 
For Dad 


\section{Acknowledgements}

\section{Chair:}

Dr. Jason MacDonald - thank you for believing in me, pushing me, and putting up with me at my most challenging and lowest moments. At times my lack of confidence can be crippling, but you always guided me through phases of mental and psychological paralysis. If not for you, I would not have had the courage to apply for the job I ultimately got. I had actually decided to give up on academic jobs, period, until our lunch and conversation at the end of the fall semester. Thank goodness I listened, and didn't give up on wanting more. That's because of you. Look for Quotidian, the Limitation Rider Lizard on a bookshelf near you soon.

\section{Committee:}

Dr. Woldoff--meeting you was so much fun. You're so smart and easy to talk to. I really appreciated your perspective as part of my committee.

Dr. Jacobsmeier--without you, I would not have fallen in love with the racial and ethnic politics field and found my eventual path. Thanks for being a great graduate director, all the help leading up to the interview and job talk, and for wisely reminding me, "Skype is really weird," when I worried that the Skype interview hadn't gone well. Clearly, it went fine.

Dr. Worsham--you've been in my corner since day 1. To this day, no one else has written on my work, "Now you're just showing off," or "A real tour de force." (Of course, more recently you wrote "ugh cubed" so things have gotten a little worse since.) Thank you for the unwavering support and many opportunities over all these years, including the conference that got me outside the US for the first time.

\section{Others in the political science department:}

Dr. Crichlow - thank you for leading the department and creating so many opportunities for graduate students. Top 100!

Dr. Phillips--thank you for supporting me through the Dissertation Success Program and always lending guidance and advice.

Dr. Cassese--you're the first person who helped me see what the back and forth nature of the research process is like. I really appreciated your including me (and Lauren and Brian) in the summer research feedback group that included faculty a few years ago--an excellent learning experience. More specifically, thanks for the idea of using the word "narrow" in my theory. 
Dr. DiClerico--You've been a mentor and guide for thirteen years now, and I cannot imagine my life without your influence. You are the best teacher and person anyone could try to emulate.

\section{Student colleagues:}

Lauren and Brian--thank you for reading my youngest, ugliest drafts and encouraging me every step of the way. So many times you boosted me back up when I felt like throwing in the towel.

\section{Furries:}

Cats--thanks for not putting all of my pens under the furniture and for keeping my laptop warm.

Opie--my fuzzy wonder-dog, thanks for seeing mommy through two (technically three) graduate degrees and still loving her anyway.

\section{Family:}

Elisha and Cole--thanks for marrying my siblings and keeping them out of my hair while I am working.

Daisy, Lucy, Wes, Levi, New Baby--The five-ish of you have never known me as anything but a graduate student. I am glad soon you'll know me as a professor, with a salary to spend on all things Fisher Price. You all make me so happy.

Jeanna--thanks for being my sister and friend, and for introducing me to Moana. The influence of Moana in the final months of my dissertation CANNOT be overstated. Your efforts to be your best self and live life fully inspire me to do the same for myself.

R.J.--thanks for reading drafts, making PDFs and never complaining, caring about creation, inspiring me with your work, and sending me GIFs. If you hadn't helped out when I went to interview at OWU, I would not have been nearly as focused.

Mom-We've had a difficult five years, haven't we? But we never gave up. You are so brave to go through all you have and keep fighting. Watching you work through your health challenges, in particular, showed me there can always be new beginnings--you've proved that over and over.

Dad-I'm so glad you knew I was going to pursue the Ph.D. For all the times I wished you were here during this process, I wish you were here for this last bit the most. If we meet again, no need to call me Professor Nestor. Being your "Little Sweetheart" was always enough. 
Table of Contents

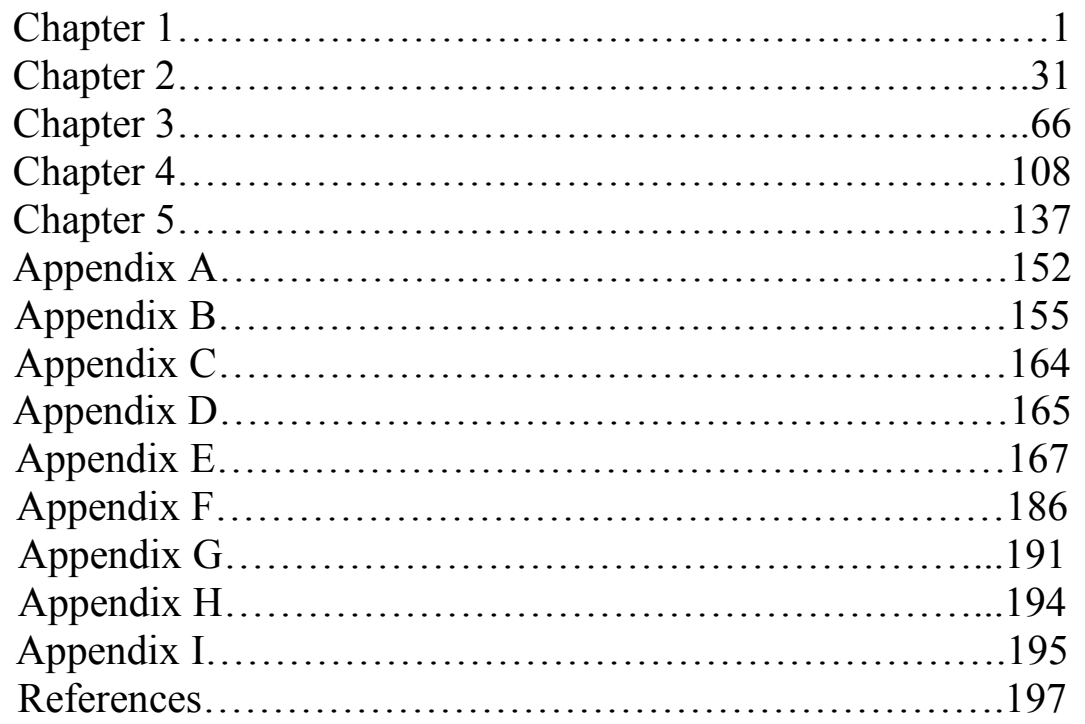




\section{List of Tables}

\section{Chapter 1}

Table 1: Explicitly and Implicitly Racial Issues and Frames in the Literature

\section{Chapter 2}

Table 1: Racialization of Opinion

Table 2: Differences in Mean Opinion Between Groups by Income Level

Table 3: African American Opinion by Lowest and Highest Income Percentiles

Table 4: Latino Opinion by Lowest and Highest Income Percentiles

Table 5: Responsiveness and Income

Table 6: Responsiveness and Race

\section{Chapter 3}

Table 1: American Taxpayer Relief Act Vote

Table 2: TARP Vote

Table 3: Comparing Parties on Explicitly and Implicitly Racial Issues

Table 4: Comparing Legislators by Race

Table 5: Comparing Legislators at the Intersection of Race and Party: Democrats of Difference Races

Table 6: Comparing Legislators at the Intersection of Race and Party: Democrats and Republicans

Table 7: District Racial Population and Median Income and Bill Sponsorship

\section{Chapter 4}

Table 1: List of Committee Names Included in the Analysis

Table 1a: Oversight on Explicitly Racial Issues-Logit Analysis

Table 1b: Oversight on Explicitly Racial Issues-Negative Binomial Analysis

Table 2a: Oversight on Implicitly Racial Issues_-Logit Analysis

Table 2b: Oversight on Implicitly Racial Issues - Negative Binomial Analysis

Table 3a: Democratic Majorities Only: Oversight on Explicitly Racial Issues-Logit Analysis

Table 3b: Democratic Majorities Only: Oversight on Implicitly Racial Issues-Negative Binomial Analysis

Appendix C: Differences in Median Opinion between Groups by Income Level

Appendix D: White Opinion by Income

Appendix F: Bill Sponsors

Appendix H: Impact of at Least One African American or Latino Member on Committees for Explicitly Racial Oversight, Logit Analysis

Appendix I: Racially Salient Oversight and Ideology, Negative Binomial Analysis; Racially Salient Oversight and Ideology, Logit Analysis 


\section{List of Figures}

\section{Chapter 1}

Figure 1: Issue Racialization Continuum

\section{Chapter 2}

Figure 1: The Continuum of Racialized Issues-African American and White Opinion

Figure 2: The Continuum of Racialized Issues-Latino and White Opinion

Figure 3: African American Opinion: Magnitude of Significant Differences

Figure 4: Latino Opinion: Magnitude of Significant Differences

\section{Chapter 3}

Figure 1: Latinos and TARP Vote

Figure 2: Simulated Votes on TARP; Democrats

Figure 3: Simulated Votes on TARP; Republicans

Figure 4: Simulated Votes on TARP; Democrats with Large Latino Populations

Figure 5: Simulated Votes on TARP; Republicans with Large Latino Populations

Figure 6: White Median Income and TARP Vote

Figure 7: Simulated Probability of Voting "Yes" on TARP, Among Conservatives

Figure 8: Simulated Probability of Voting "Yes" on TARP, Among Conservatives (DWNOM 1 Only)

Figure 9: Simulated Probability of Voting "Yes" on TARP, Among Conservatives (DWNOM 2 Only)

Figure 10: Simulated Probability of Voting "Yes" on TARP, Among Conservatives with Large Latino Populations in Their Districts

Figure 11: Simulated Probability of Voting "Yes" on TARP, Among Conservatives with Large Latino Populations in Their Districts (DW-NOM 1 Only)

\section{Chapter 4}

Figure 1: Percentage of Committees with African American Members, by Congress

Figure 2: Percentage of Committees with Latino Members, by Congress

Figure 3: Model Comparison, Explicit Logit Models

Figure 4: Model Comparison, Implicit Negative Binomial Models

Figure 5: African American Committee Members and Implicit Oversight

Appendix G: Map: Racially Salient Bill Sponsorship by State 


\section{CHAPTER ONE}

\section{$\underline{\text { INTRODUCTION }}$}

Whites and nonwhites tend to view government policy differently, with Blacks and Latinos especially tending to be much more liberal and much less aligned with the direction of government outcomes (e.g., Bowler and Segura 2011). We cannot understand or solve this potential problem of lacking government responsiveness without an understanding of the complexities of opinion across and within racial groups, and across policies. Unfortunately, data limitations and persistently small sample sizes of nonwhite respondents in surveys have hampered our ability to assess Black and Latino opinion, and as a result government responsiveness to that opinion, in a comprehensive way.

This does not mean the effort is not underway; it is simply incomplete. Scholars studying the role of racial group consciousness in public opinion find that the impact of racial group membership varies with the nature of the issue (e.g., Kinder and Winter 2001; Sanchez 2006; White 2007). Opinion differences between racial groups occur on many issues, but especially on racialized issues, which can be envisioned as falling along a continuum from more explicitly to more implicitly racial. The differences are especially pronounced on racialized issues that are explicit, which are obviously racial and include such issues as affirmative action and immigration. Differences are more nuanced on racialized issues that are implicit, which affect higher proportions of Blacks and Latinos than whites but are nevertheless not explicitly racial, such as poverty, welfare, and crime. While racialized issues are often nuanced in their degree of 
racialization, research shows that degree matters (Kinder and Winter 2001; Sanchez 2006; White 2007).

Gilens (2012), meanwhile, points out the influence of income on opinion. Lowincome and high-income survey respondents, as one might expect, tend to see issues related to economic policy and social programs differently. The interaction of these two sources of opinion splits, income and race, is not as well understood. Black and Latino opinion is not "monolithic" (Orey, Craemer, and Price 2013); thus, we should aim to explore not just racially-driven opinion splits but other sources of dispute, including income. When does racial group consciousness matter more? When does income matter more? Generally, samples of nonwhite respondents are too small to permit examination of both variables at once. This dissertation uses a dataset with large samples of Blacks and Latinos - the Cooperation Congressional Election Studies (CCES) — and examines the influence of both race and income upon opinion.

Even less understood is the impact of these potential opinion differences on representation. What effect do these potential differences have upon meaningful representation of disadvantaged groups, such as Blacks, Latinos, low-income individuals, and those who are doubly disadvantaged - those who are both racially and economically disadvantaged? Gilens (2012) has shown that when low-income and high-income respondents disagree, the high-income minority wins out. Government is more likely to respond to the changes desired by the high-income individuals, despite what low- and middle- income individuals desire. We know Blacks and Latinos are disadvantaged when it comes to representation in government, but does that hold when government policy responsiveness is examined? Are low-income members of these groups 
particularly disadvantaged when it comes to government responsiveness? Can Blacks and Latinos ever "win" the representation game, even when their opinions differ from white opinion? Is there a difference in representation when one examines explicitly and implicitly racial issues separately?

These are the questions I explore. I theorize that representation of Blacks and Latinos is a narrowly constructed representation, focusing more on issues that are explicitly racial rather than implicitly racial, even if the implicit issues are substantively important for nonwhite groups. This project yields important insights about the nature of public opinion and representation in a variety of venues, and their combined effect upon the policies that aid the most disadvantaged members of our society. Answering these questions is crucial to uncovering the possible ways our democracy systematically favors certain groups over others.

\section{THE LITERATURE, AND ITS UNANSWERED QUESTIONS}

\section{Group Consciousness}

Persistent opinion divides between Blacks, Latinos, and whites, especially Blacks and whites, are a common theme in racial and ethnic politics literature (e.g., Kinder and Winter 2001; Sanchez 2006; White 2007). Why do Blacks, Latinos, and whites tend to see political issues differently? Some authors focus primarily on group consciousness (Dawson 1995), some add other personal factors to group consciousness such as income and political principles (e.g., Kinder and Winter 2001; Sanchez 2006), and others focus on how the impact of group consciousness versus other predictors varies depending on the nature of the issue (e.g., Kinder and Winter 2001; Sanchez 2006; Tate 1993; White 
2007). In addition, other scholars remind us not to assume group opinion is uniform (e.g., Orey, Craemer, and Price 2013; Strolovitch 2007).

What is group consciousness? Scholars tend to measure it and define it in different ways, from feelings of closeness with one's in-group (Leighley and Vedlitz 1999), to "linked fate" (Dawson 1995), to "social identity" (Kinder and Winter 2001). In fact, McClain et al (2009) argue that scholars need to be more careful about how the concept of group consciousness is defined and measured. According to McClain et al (2009), group consciousness is distinct from both group membership and group identity. Group membership is self-placement within a group based on certain characteristics specific to that group, and group identification requires awareness of belonging to a group and a sense of shared interests with other members of that group. Group consciousness is a third concept, which is group identification with politicization of that group identification added in. Group consciousness can be demonstrated by beliefs about the group's social rank relative to other groups.

\section{Group Consciousness and Opinion}

Regardless of the exact terminology or measurement used, the idea of group consciousness as it relates to opinion is that group membership may bind individuals in a group in their opinions across a wide variety of issue areas, even after considering possible differences between group members, such as income level. For example, Dawson (1995) argues that socioeconomic differences among Blacks are of little to no importance in their policy preferences and choices. Rather, what matters is linked fate, Dawson's form of group consciousness, whereby Blacks make policy choices based on what they believe will be best for their racial group as a whole. 
Some posit that work on group consciousness assumes opinions among nonwhite groups are "monolithic" (Orey, Craemer, and Price 2013). For example, Dawson's (1995) findings suggest little to no difference in opinion on issues among Blacks of different income levels. Other scholars state that other individual characteristics matter beyond the influence of group consciousness on opinion. Tate (2003) argues that middle and higher income Blacks are less likely to support social welfare policy than low income Blacks. Sanchez (2006) explores a complicated finding for Latinos: group consciousness matters, but so do differences among Latinos, such as their English proficiency, citizenship status, and nativity. Kinder and Winter (2001) discover that group consciousness matters, but so do income differences and differences in political principles.

Related to the idea that group opinion is not as monolithic as the group consciousness literature sometimes suggests is work on intersectionality. The intersectionality literature (e.g., Bowleg 2008; Cole 2009; Hawkesworth 2006; Hancock 2007; Weldon 2006; Strolovitch 2007; Wadsworth 2011) posits that identities and opinions are created at the intersection of differences such as race, ethnicity, class, and gender, and that scientists tend to do a poor job evaluating these overlapping distinctions, which can result in different experiences and perspectives.

Finally, some authors point out the role of issue type. Group consciousness matters more for some issues than for others. According to Kinder and Winter (2001), the opinion divide between whites and African Americans on issues like federal spending on affirmative action do not disappear when income differences between the groups are removed. However, group differences in opinion between Blacks and whites do lessen 
once income differences are removed on social welfare issues such as welfare and health insurance. For Sanchez (2006), too, group consciousness among Latinos mattered most on Latino-salient issues and less on general issues. Group consciousness and interest among working class whites mattered only for race-targeted, not income-targeted, policies for Bobo and Kluegel (1993) as well (such as scholarships for African American children versus scholarships for poor children). It seems, as Valentino, Hutchings, and White (2002) explain, that group consciousness is not as consistent or reliable on nonracial or less clearly racial issues.

What kinds of issue areas are clearly, or explicitly, racial, and which are perhaps more salient for Blacks and Latinos than they are for whites but nonetheless not explicitly racial? Using an experiment, White (2007) shows how issues framed differently can lead to different opinions among whites and Blacks. Explicit frames explicitly mention or reference Blacks. Implicit frames, on the other hand, only implicate Blacks, rather than outright naming them, by linking an issue to problems, such as poverty, that affect Blacks at higher proportions than members of the white racial grouping. White's experiment and findings focus on the role of language less than policy, and on how language can explicitly or implicitly racialize nearly any issue to greater or lesser degrees, but it is still the case that some issues in themselves are more explicit in their racial context than others. Other scholars are more direct in the application of these racialized frames to public policy opinions. For Sanchez (2006), Latino-salient issues include immigration and bilingual education, which unavoidably include a racial context. He also includes the death penalty, however, which is only implicitly racial — it may be of salience to Latinos because of the higher rates of members of these groups in prison and on death row, but it 
is not an explicitly racial policy like immigration. Similarly, Bobo and Kluegel (1993) distinguish between race-targeted and income-targeted policies and the differential effects these have on white and Black opinion. Whites are less supportive of explicitly race-targeted policies than of income-targeted policies, but Blacks were supportive of both.

What's missing in these studies is an attempt to examine opinion differences along race and income lines simultaneously, despite the importance of intersectional identity (Strolovitch 2007). Many authors examine Black opinion or Latino opinion versus white opinion (e.g., Bobo and Kluegel 1993; Dawson 1995; Kinder and Winter 2001; Sanchez 2006; White 2007). Some study, or at least briefly examine, high income versus low income opinion (Dawson 1995; Gilens 2012; Kinder and Winter 2001; Tate 2003). The intersection is often ignored. The reason for this is likely less a lack of interest and more a lack of data. Finding surveys with representative samples of any racial group other than whites is very difficult; finding surveys with representative samples of racial groups large enough to break up racial categories further by income is even more of a challenge. As a result, these questions about the role of income and race in racialized issue opinion go unanswered.

\section{A Word About Self-Interest and Symbolic Politics}

Uncovering the source of opinion differences is important. Relatedly, when studying the opinions of groups of individuals, it's crucial to be careful about the way we conceive of "self-interest." It is problematic to assume what opinions should be in the disadvantaged individuals' self-interest, and it is equally problematic to assume that 
opinions at any income level, or any racial category, are driven entirely by these individuals' conceptions of their categorical self-interest.

The "symbolic politics" strand of research differentiates between short-term, rational, cost-benefit analysis-driven self-interest as an explanation for public opinion, and the "symbolic politics" explanation. That is, such research posits that "people acquire stable preferences through conditioning in their preadult years, with little calculation of the future costs and benefits of these attitudes. The most important of these are presumably some rather general predispositions, such as party identification, liberal or conservative ideology, nationalism, or racial prejudice" (Sears et al 1980, 671).

Sears et al (1980) used measures of self-interest and symbolic politics measures in four issue areas: unemployment, national health insurance, busing, and crime. They were unable to find evidence to support self-interest as the driver for opinion in these areas. For example, whether or not an individual had health insurance, or had a child likely to be affected by busing, did not have a relationship with individuals' opinions on these issues. Instead, party identification, ideology, and racial prejudice explained opinions better. The impact of racial prejudice on white opposition to busing was especially pronounced (Sears et al 1979). The same was true for voting in Los Angeles mayoral elections. Symbolic racism, rather than perceived racial threat from Blacks (such as Blacks' proximity to white voters' neighborhoods, schools, and jobs), determined the likelihood of voting against the Black candidate (Kinder and Sears 1981).

Sears, Lau, Tyler and Allen (1980) also found no evidence that the interaction of local conditions, such as living in a state with a high number of uninsured individuals, with self-interest motivates individual opinion. Sears and Funk wrote, "The effects of 
self-interest usually extend neither to other related policy issues nor to more general policy or ideological questions. The general public seems to think about most political issues, most of the time, in a disinterested frame of mind" $(1991,77)$. Lau and Heldman (2009) extended the examination into the 2000s, with the same results.

This is not to say self-interest never matters. Wolpert and Gimpel (1998) uncover ample evidence for the self-interest hypothesis in the area of gun control: those who own guns are more sensitive to gun control. They link this seemingly unlikely result to Sears and Funk's (1980) own suspicion that self-interest may be activated when individuals "attribute their personal well being to government action in question" (Wolpert and Gimpel 1998, 255). In addition, Wolpert and Gimpel believe the NRA assists as a selfinterest "trigger" with the argument that gun laws will only restrict "good guys," leaving those responsible with guns and respectful of the law less safe (255). Crano (1997), meanwhile, tries to bridge the two camps by suggesting that vested self-interest does moderate opinion; respondents' self-interest does seem to matter for their responses if they perceive that self-interest and perceive it as important. That perception of importance is what determines how "vested" a self-interest is, and, moreover, its connectedness to opinion. This provides a caution that we, as researchers, ought to be careful in dictating what is, or is not, of differential interest to respondents.

Most relevant to this work, Bobo and Kluegel (1993) agree that individual selfinterest matters little, but state that the role for group self-interest in racialized policy areas depends upon the activation of "race-targeting" versus "income-targeting" in a policy, and whether or not the policy aims to equalize opportunity or outcome. Even though the symbolic politics attitude of racial tolerance remained important in 
determining support for race-targeted equal outcomes policies among whites, group selfinterest mattered too: those who perceived themselves as members of the working class were particularly opposed to race-targeted policies. This, despite the fact that Kinder and Kiewit (1979) were unable to discover any relationship between individual economic circumstances and congressional voting, even when looking for differences among subgroups such as union members, or those who perceived themselves as being in the working class. Context may be key in determining the role of group- or self-interest, which certainly relates to this effort to differentiate between explicitly and implicitly racial issues. Ideally, then, examinations of opinion differences based in hypotheses about supposed self-interest, including income, ought to include the possibility of competing explanations rooted in long-term political beliefs such as party identification, ideology, and racial tolerance.

\section{Opinion Splits and Government Responsiveness}

Why do differences in opinion between and among groups and individuals matter, though? They matter because, in a representative democracy, we expect that individuals' desires are represented by their government. As Griffin and Newman (2008) write, "If a citizen's preferred course of action for the government is consistent with what the government subsequently does, we can conclude that the citizen is well-represented" (157). If group preferences diverge, and one group is consistently more likely to be thwarted in its desires for the direction of government, this creates undemocratic outcomes. How do opinion differences on racial issues matter for representation?

Gilens (2012) provides an example of a one-dimensional look at opinion differences and their correspondence with representation losses or wins. Gilens 
demonstrates that when preferences between low-income and high-income citizens diverge, policy tends to follow the preferences of higher income citizens, rather than lower income citizens. Critically, for the purposes of my dissertation, Gilens does not focus on racial differences, though, in either opinion or issue area, only income. Gilens believes that surprising representation wins for low-income groups-such as the continued lack of privatization on Social Security that higher income individuals support — are due to significant advocacy group support and activity on this issue. This implies that disadvantaged individuals can have their opinions represented better when advocacy groups are fighting for their side.

Griffin and Newman (2008), meanwhile, focus on the role of issue salience. Like Gilens, they recognize the role of advocacy and opinion intensity in representation, beyond the impact of opinion itself. Unlike Gilens, Griffin and Newman incorporate the role of race and racialization - both in opinion and in issue type--and argue it matters beyond income. They argue surprising representational wins on racial issues, counter to what the majority of whites would desire, means issues that are especially salient to Blacks and Latinos can win regardless of majority rule.

Which Blacks and Latinos are having their opinions heard, though? Can we depend on issue salience to provide the voice for the disadvantaged? Again, the literature on intersectionality cautions us to recognize differences within groups and the impact they have on opinion and representation. This continues to be a missing piece.

Strolovitch (2007) might argue that Gilens is right that advocacy means unexpected wins can occur, though she would point out it certainly does not ensure wins for everybody who desires representation. Further, though Griffin and Newman (2008) 
might argue salience can win the day for the disadvantaged, Strolovitch might add that salience only leads to strong representation for the comparatively advantaged of the disadvantaged. This further privileges the comparatively advantaged and perpetuates the lack of representation for those citizens with overlapping disadvantaged identities.

Though Strolovitch's examination of advocacy groups gives us some hints about what may happen to government responsiveness at the intersection of income and race, so far, these questions remain unanswered. After imputing opinion by income and race, I examine three ways government does or does not respond: as a body on roll call votes (Chapter 2), as individual legislators on roll call votes and sponsorship (Chapter 3), and as congressional committees on oversight (Chapter 4).

Substantive versus Descriptive Representation and Individual Legislators So far, I have focused on "government" as a body. How much do differently racialized issues and opinion differences based on income and race matter for individual legislators? What determines representative responsiveness at the individual level?

Mayhew (1974) argues the desire to be reelected does, in which case constituency makeup would determine whether group interests are represented. Miller and Stokes (1963) point out that representatives act differently, as either trustees or delegates, depending on the nature of the issue. Racial and ethnic politics scholars recognize that constituency makeup is a possible determinant of representation for African American interests (Grose 2011). Districts or states with higher numbers of Blacks and Latinos might determine group representation, because their votes are potentially important for reelection. Thus, the size of a group population in a given district may be crucial in determining responsiveness. 
In racial and ethnic politics, any discussion of representative responsiveness must include a look at representative race as well. Descriptive representation, often bolstered by majority-minority districts, aims to improve substantive representation. Again, an assumption of shared racial group consciousness is the driving force behind such notions: an African American legislator is more likely to better represent African American interests than a white legislator because the African American legislator identifies more clearly with those of his or her own race. The same thinking underlies the creation of Latino majority-minority districts.

Does descriptive representation fulfill its promise, however? The answer to this is far from clear, especially at the aggregate level (e.g., Grose 2011; Lublin 1999; Lublin and Voss 2003; Shickler et al 2010; Swain 1995). At the individual behavior level, too, there are conflicting findings. Griffin and Flavin (2007) find that African Americans tend to be less politically knowledgeable and less accurate than whites at identifying the ideological position — and thus substantive policy direction--of their representatives, and, correspondingly, less likely to punish their representatives at the polls for diverting from citizen preferences. Further, Griffin and Newman (2007) say that Lublin's (1999) suggestion for African American influence districts might not work for Latinos-in what they call Latino "threat districts" with between $40-50$ percent Latinos, there was a huge proximity gap between the preferences of Latino citizens and their white representatives. Griffin and Newman argue that descriptive representation might matter most in such districts, but in other districts with lower or higher percentages of Latinos, Latino citizens were sufficiently close to their Democratic representatives, white or Latino, to make the substantive representation argument more about ensuring similar partisan identification 
rather than descriptive representation in those districts. Finally, Gay (2001), without examining individuals' voting calculus, finds that majority-minority districts rarely increase black turnout much over non-majority-minority districts, and decrease white turnout.

Still, Gay (2001) says that in the rare cases majority-minority districts improve black voter turnout, it can do so to the tune of six to 26 percentage points. Other scholars discover similar positive signs for majority-minority districts at the individual behavior level. Banducci et al (2004) find that in the US and New Zealand, descriptive representation can improve evaluations of and contact with representatives, and turnout and evaluations of the system, respectively. Bobo and Gilliam (1990) argue that blacks living in districts with black mayors are more empowered and politically engaged, because they are also more knowledgeable about their local governments - a fact that would also improve government responsiveness. Barreto et al (2004) believe that majority-minority districts consistently improve Latino turnout in California, across types of elections, and do so additively when voters live in more majority-minority districts (though they do decrease white turnout). Better Black and Latino turnout can lead to a government that is more substantively responsive to Blacks and Latinos. Grose (2011) explains how this can work and relates it to substantive representation: black legislators rely on black voters more than white legislators, so they take care to cultivate those votes through not just roll call voting but project delivery and constituency service. At the district level, there are positive signs as well. Gay (2007) uses votes on referenda in California to measure citizen desires, and says that majority-minority districts are just as responsive as majority-white districts. 
Where does income factor into all of this, though? When opinions of highincome African Americans or Latinos diverge from low-income African Americans or Latinos, what happens? Swain (1995) argues that the wealthy African American representatives who get elected are no more like their African American constituents than are wealthy white representatives. Tate (2003) disagrees with Swain (1995) that African American representatives are just as different from their African American constituents as white representatives. In her mind, the black experience is a similarity that crosses wealth differences. Who's right? More specifically for my purposes, does the theme of narrow representation exist regardless of representative race? In Chapter 3, I examine the voting and sponsorship behavior of individual members of Congress on implicitly and explicitly racial issues, considering their party, ideology, district, and race.

\section{Oversight and Racial Representation}

Finally, these unanswered questions about race, income, opinion, and representation extend to the oversight arena as well. As stated previously, Grose (2011), Minta (2011), Minta and Sinclair-Chapman (2013), and Tate (2003) emphasize the importance of moving beyond roll call voting to find the influence of legislator race upon legislator behavior. Minta (2011) takes this approach to the oversight arena, discovering that nonwhite members of Congress contribute more lines of text (that is, say more) at oversight hearings than white members of Congress on both racial and social welfare issues. But to what end? Are there more hearings relating to racialized policy overall on committees with greater numbers of Black and Latino members?

FILLING IN THE GAPS: A THEORY OF RACIALIZED REPRESENTATION 
My dissertation combines knowledge from opinion and representation literatures to examine Black and Latino representation on racially salient issues. I theorize that representation of Blacks and Latinos is a narrowly constructed representation, more likely on issues that are explicitly, rather than implicitly, racial. My exploration involves national opinion data of whites, Blacks, and Latinos at different income levels, and extends into congressional representation, individual legislator responsiveness, and congressional oversight. If I am correct, this theory suggests representation systematically does not meet the needs of the most economically disadvantaged Blacks and Latinos when it comes to issues that are not explicitly racial.

To bring the opinion and representation literatures together and examine public opinion and government responsiveness more precisely, I adapt Gilens's (2012) approach, while incorporating race, not just income, and while incorporating explicitly and implicitly racial issues. That is, I use survey data to impute preferences by income, race and race and income together.

\section{Explicit and Implicit: What does it mean?}

Explicitly racial issues are clearly related to race or ethnicity. These would include questions pertaining to affirmative action, racial integration, immigration, and bilingual education. Implicitly racial issues are issues that affect Blacks and Latinos at higher rates because of the higher proportions of these populations, relative to whites, affected by the issue — often due to poverty—but not automatically due to race. They do not refer explicitly to race. These might include welfare, the minimum wage, healthcare, troop withdrawal, or even pollution and climate change (large number of Blacks and 
Latinos are affected by allergies and asthma, a problem many scientists believe is exacerbated by pollution and/or climate change) ${ }^{1}$.

Though there is certainly some subjectivity inherent in such classifications, this approach is not dissimilar from Mendelberg's (2001). Mendelberg is interested in the use of racially-charged appeals, explicit versus implicit, by candidates in parties in political campaigns, and how these appeals vary based on changing societal norms with persistent racial biases underneath. In addition, in her experiments, Mendelberg uses visual cues, not just words, to create implicit appeals. That is not my purpose here. However, in coding speeches from the past, Mendelberg uses an explicit versus implicit framework. Explicit appeals explicitly mention race, words like "whites," "race," "racial," "Negroes," "Martin Luther King," "SCLC." However, "a word belongs in the implicit category if it does not directly refer to African Americans or whites but had a racial association at the time (e.g., 'activist' can mean a person active on behalf of any cause, but in the context of the civil rights bill and the highly salient activities of the civil rights movement, its primary association is likely to have been a person active on behalf of civil rights)" (77). Implicit words for Mendelberg are wide-ranging, and include "sit-ins," "protest," “demand," and "constitutional rights." Though our approaches and questions are different, we both rely upon context to define the implicitly racial nature of an issue (me) or an appeal (Mendelberg). I am particularly interested in the extent to which the substance of an issue and whom it affects racializes it.

\footnotetext{
${ }^{1}$ http://www.ncbi.nlm.nih.gov/pmc/articles/PMC3920741/ http://www.niehs.nih.gov/research/programs/geh/climatechange/health_impacts/asthma/i $\underline{\text { ndex.cfm }}$
} 
Particularly since framing can lead to racialization of just about any issue (White 2007), it is also important to note that I am not attempting to create an artificial distinction between all those issues for which racialization is important. Rather, I am noting that these issues fall on a continuum, being more or less explicit in their racialization, and hypothesizing that this may have some impact on opinion and resulting representation. I see the continuum as potentially constructed as seen in Figure 1.

$\underline{\text { Figure 1: Issue Racialization Continuum }}$

Explicitly Racial

Affirmative Action

Immigration
Implicitly Racial

Welfare

Abortion

Health care

Social programs

Housing assistance

This idea is not out of sync with how other authors beyond Mendelberg have operationalized these concerns. Table 1 provides some examples:

Table 1: Explicitly and Implicitly Racial Issues and Frames in the Literature

\begin{tabular}{|c|c|c|c|c|}
\hline Author(s) & $\begin{array}{c}\text { Name for } \\
\text { explicitly racial } \\
\text { issues }\end{array}$ & $\begin{array}{l}\text { Explicitly racial } \\
\text { issues examined }\end{array}$ & $\begin{array}{l}\text { Name for } \\
\text { implicitly } \\
\text { racial issues }\end{array}$ & $\begin{array}{l}\text { Implicitly racial } \\
\text { issues examined }\end{array}$ \\
\hline $\begin{array}{l}\text { Bobo and Kluegel } \\
1993\end{array}$ & $\begin{array}{l}\text { Race-targeted } \\
\text { policies }\end{array}$ & $\begin{array}{l}\text { Opportunity- } \\
\text { enhancing } \\
\text {-enterprise zones for } \\
\text { black areas } \\
\text {-special school funds } \\
\text { for black } \\
\text { neighborhoods } \\
\text {-college scholarships } \\
\text { for black children } \\
\\
\text { Outcome-enhancing } \\
\text {-Should government }\end{array}$ & $\begin{array}{l}\text { Income- } \\
\text { targeted } \\
\text { policies }\end{array}$ & $\begin{array}{l}\text { Opportunity- } \\
\text { enhancing } \\
\text {-enterprise zones } \\
\text { for poor areas } \\
\text {-special school } \\
\text { funds for poor } \\
\text { neighborhoods } \\
\text {-college } \\
\text { scholarships for } \\
\text { economically } \\
\text { disadvantaged } \\
\text { children } \\
\text { Outcome- } \\
\text { enhancing }\end{array}$ \\
\hline
\end{tabular}




\begin{tabular}{|c|c|c|c|c|}
\hline & & $\begin{array}{l}\text { increase the standard } \\
\text { of living for blacks? } \\
\text {-Should government } \\
\text { increase assistance to } \\
\text { blacks? }\end{array}$ & & $\begin{array}{l}\text {-Should } \\
\text { government } \\
\text { increase the } \\
\text { standard of living } \\
\text { for the poor? } \\
\text {-Should } \\
\text { government } \\
\text { increase assistance } \\
\text { to the poor? }\end{array}$ \\
\hline Mendelberg 2001 & Explicit appeals & $\begin{array}{l}\text { Campaign appeals } \\
\text { that use explicitly } \\
\text { racial words, like } \\
\text { "whites," "race," } \\
\text { "racial" }\end{array}$ & $\begin{array}{l}\text { Implicit } \\
\text { appeals }\end{array}$ & $\begin{array}{l}\text { Words do "not } \\
\text { directly refer to } \\
\text { African Americans } \\
\text { or whites but had a } \\
\text { racial association at } \\
\text { the time;", e.g., "sit- } \\
\text { ins," "protest," } \\
\text { "boycott,", } \\
\text { "march," "civil } \\
\text { disobedience," } \\
\text { "constitutional } \\
\text { rights," "quota" }\end{array}$ \\
\hline Sanchez 2006 & $\begin{array}{l}\text { "Issues salient to } \\
\text { the Latino } \\
\text { community" }\end{array}$ & $\begin{array}{l}\text {-Immigration } \\
\text {-Bilingual education } \\
\text { in public schools }\end{array}$ & $\begin{array}{l}\text { Issues "not } \\
\text { directly tied } \\
\text { to Latinos" }\end{array}$ & $\begin{array}{l}\text {-Abortion } \\
\text {-Death penalty }\end{array}$ \\
\hline White 2007 & Explicitly racial & $\begin{array}{l}\text {-Explicit frame for } \\
\text { Iraq war opinion: } \\
\text { noting that many } \\
\text { causalities may be } \\
\text { members of minority } \\
\text { groups } \\
\text {-Explicit frame for } \\
\text { opinion on food } \\
\text { stamps: noting that } \\
\text { cutting spending for } \\
\text { the program will } \\
\text { disproportionately } \\
\text { hurt African } \\
\text { Americans and } \\
\text { Hispanics }\end{array}$ & $\begin{array}{l}\text { Implicitly } \\
\text { racial }\end{array}$ & $\begin{array}{l}\text {-Implicit frame for } \\
\text { Iraq war opinion: } \\
\text { noting that the real } \\
\text { war is the one on } \\
\text { poverty, inadequate } \\
\text { health care, and } \\
\text { lack of affordable } \\
\text { housing } \\
\text {-Implicit frames for } \\
\text { opinion on food } \\
\text { stamps: noting that } \\
\text { cutting } \\
\text { programming will } \\
\text { hurt inner city } \\
\text { families; plunge } \\
\text { poor families } \\
\text { deeper into poverty }\end{array}$ \\
\hline $\begin{array}{l}\text { Kinder and } \\
\text { Winter } 2001\end{array}$ & Race & $\begin{array}{l}\text {-Should the federal } \\
\text { government ensure } \\
\text { equal opportunity? } \\
\text {-Should the federal } \\
\text { government see to }\end{array}$ & $\begin{array}{l}\text { Social } \\
\text { Welfare } \\
\text { Policy }\end{array}$ & $\begin{array}{l}\text {-Should we cut } \\
\text { spending or expand } \\
\text { services? } \\
\text {-Should we } \\
\text { increase spending }\end{array}$ \\
\hline
\end{tabular}




\begin{tabular}{|l|l|l|l|l|}
\hline & & $\begin{array}{l}\text { School desegregation? } \\
\text {-Should the federal } \\
\text { government spend } \\
\text { money to assist } \\
\text { blacks? } \\
\text {-Preferential Hiring } \\
\text {-College Quotas }\end{array}$ & $\begin{array}{l}\text { on... } \\
\text { education/programs } \\
\text { that help the } \\
\text { poor/college } \\
\text { aid/the } \\
\text { unemployed/ the } \\
\text { homeless/health } \\
\text { insurance/the } \\
\text { provision of jobs? }\end{array}$ \\
\hline $\begin{array}{l}\text { Rabinowitz et al } \\
2009\end{array}$ & $\begin{array}{l}\text { Policies } \\
\text { "designed to help } \\
\text { blacks" }\end{array}$ & $\begin{array}{l}\text {-Preferential hiring } \\
\text {-Requiring } \\
\text { affirmative action of } \\
\text { companies with a } \\
\text { history of } \\
\text { discrimination }\end{array}$ & $\begin{array}{l}\text { Social } \\
\text { programs } \\
\text { with "racially } \\
\text { ambiguous" } \\
\text { beneficiaries }\end{array}$ & $\begin{array}{l}\text { Spending on: } \\
\text {-Welfare } \\
\text {-Food stamps } \\
\text {-Aid to the poor } \\
\text {-Social Security } \\
\text {-The homeless }\end{array}$ \\
\hline
\end{tabular}

The work of Gilens (1999) and Hancock (2004) suggest that welfare may occupy a strange space, seemingly nonracial but, in fact, heavily racialized due to the conflation of race, poverty, and welfare in the media. Gilens (1999) writes that following the northern migration and the change in the demographics of individuals on the Aid to Families with Dependent Children rolls, along with civil rights movements and clashes at that time, the media consistently overrepresented the level of black welfare dependency. This image of African Americans as the lazy and undeserving poor stuck, and continues to drive white Americans' opposition to welfare, according to Gilens (1999). Hancock (2004) adds that there is particular "disgust" for poor, black women; the "welfare queen" identity created by the media and politicians is associated with laziness, hyperfertility, drug abuse, and inner city residence, and tends to lead to policy choices that appear to place blame on individuals instead of their situations, such as workfare over free childcare. These findings urge scholars to proceed with caution in how they classify racialized issues. 
Nevertheless, though Rabinowitz et al (2009) find support for symbolic racism driving opposition to welfare, the relationship is not as strong as the relationship between symbolic racism and more explicitly racial issues such as affirmative action. Thus, the seeds for a meaningful continuum of racialization exist and might lead us to important findings. As Rabinowitz et al write,

SR's [symbolic racism's] predictive properties became attenuated when the policy strayed from specifically targeting African Americans. When attitudes such as ideology and the role of government were controlled, symbolic racism did not predict attitudes toward assistance to the homeless, assistance to the poor, or food stamps and predicted attitudes toward welfare as powerfully as it predicted attitudes toward affirmative action for Black Americans. This is despite the possibility that the homeless, the poor, and recipients of food stamps and welfare may be viewed by many Whites as being disproportionately Black (Gilens 1999)...these studies illustrate the continued importance and meaningfulness of parsing opinions about racial policies (824-825).

Certainly, implicitly racial issues are not nonracial. But it appears there may be important differences between explicitly and implicitly racial issues we should investigate, and I attempt to model these issues in ways supported by the literature.

\section{What effect does issue racialization have on opinion?}

Based on the literature, I predict that low-income citizens, regardless of their race, will be more likely to share opinions with one another, and correspondingly more likely to diverge from higher-income Americans of any race, on implicitly racial issues. These issues may affect Blacks and Latinos at higher rates than they affect those who identify as white, but they are nonetheless not explicitly racial. However, I predict that income differences will matter less than racial differences on explicitly racial issues. Here, racial group identification will matter more than income or principle differences. Explicitly racial issues explicitly pinpoint Blacks and Latinos and will lead these individuals' 
opinions to be more likely to bind together and more likely to diverge from opinions of whites on these issues, regardless of intergroup differences, such as income.

\section{What effect does this have on representation?}

Linking the opinion literature to the representation literature, I further hypothesize that government outputs are actually closer to Black and Latino respondents' opinions on explicitly, rather than implicitly, racial issues. With implicitly racial issues, which tend to correspond more with low-income opinion, the benefit is less clearly racial. As a result of this simplification, so my hypothesis goes, representation of low-income Blacks and Latinos tends to be lacking.

The direction of this hypothesis might seem surprising in light of work such as William Julius Wilson's (2012), who in the past encouraged a focus on class rather than race in public policy, and President Barack Obama's deliberate avoidance of highlighting race in political efforts, especially early in his administration (Shapiro 2013). Meanwhile, President Donald Trump has a history of injecting race into political conversations, and not in a way that emphasizes support for explicitly racial issues (O’Connor and Marans 2016). Finally, experiments such as White's (2007) also show how racializing statements can decrease support for those statements among whites. Given this, why would a better match on explicit issues be anticipated?

However, I still believe the status quo on explicitly racial policy better matches Black and Latino opinion than the status quo on implicitly racial policy. Many explicitly racial policies remain in place despite significant ire among whites. For example, seventy-five percent of whites are against affirmative action (Jones 2013) and it remains government policy (“Affirmative Action” 2015; Fisher v. University of Texas). 
Immigrants, so far, retain birthright citizenship and access to public services (Gusmano 2012; Olivas 2010; Peralta 2015; Plyler v. Doe 1982). This, despite a very white government (Krogstad 2015) and as much as half to sixty-five percent of the public, according to polls, against birthright citizenship (Kaplan 2015), and states and localities taking steps to avoid granting benefits to undocumented immigrants (Olivas 2010). In addition, though in the days of Trump this may no longer seem to be the case, since the civil rights era parties and public officials have generally attempted to avoid appearing racist, particularly on highly racialized issues (Mendelberg 2001).

Therefore, there is an argument to be made that government outputs may match Black and Latino opinion better on either implicitly or explicitly racial issues. In any case, the approach taken here will investigate the government's responsiveness to Black and Latino opinion on both explicitly and implicitly racial issues. This perspective represents an effort to expand Griffin and Newman's (2008) approach. While they incorporate the role of racialization in part of their book, they study explicit and implicit issues together, which I believe masks important distinctions. What Griffin and Newman (2008) see as potential Black and Latino group representation wins on any and all racially salient issues I believe are a result of explicitly racial issue wins grouped in with and carrying the weight for implicitly racial issues. Lumping in citizen opinion on racial job discrimination (an explicitly racial issue) and the view that poverty is a serious problem (an implicitly racial issue) and calling the result a respondent's racial issue ideology is a risky business based on what we know about the differences of white and black opinion on such distinct issues (White 2007). As a result, I believe Griffin and Newman are right that unexpected wins occur for Blacks and Latinos on racially salient issues, but I think 
they miss the importance of which type of salience we are witnessing. Narrowly racial representation is not meeting deeper needs of the most disadvantaged Blacks and Latinos.

Why would a focus on explicitly racial issues occur? Jones (1995; 2001) and Baumgartner and Jones (2010) emphasize the imperfect nature of government institutions. Just like the human brain, human organizations emphasize some dimensions of issues over others. It is simpler to serve Blacks and Latinos by focusing on explicitly racial issues. Delving into more implicitly racial issues that combine overlapping disadvantage is more complicated. Mansbridge (1999) points out the importance of "crystallization" of issues as a determinant for whether descriptive representation is necessary for a disadvantaged group. Some group interests may be better crystallized, or more clear, apparent, and/or obvious, to outsiders than others. Increased liberal ideology among Blacks and Latinos relative whites (Bowler and Segura 2011) may indicate racialized issues are crystallized completely along the continuum from explicitly to implicitly racial for Blacks and Latinos. Changes in white opinion when implicit language such as "urban" is used may indicate implicitly racial issues are at least partially crystallized for whites as well. However, condemnation for lack of support among white office holders on explicitly racial issues is much more swift (Mendelberg 2011).

Explicitly racial issues are thus still seemingly more crystallized and clear to outsiders in their benefit to Blacks and Latinos than are implicitly racial issues. Ignoring intersectional identities and overlapping disadvantage is easier than focusing on issues that are clearly racial. Thus, representation becomes narrow. I predict, then, we will be more likely to see evidence of unexpected wins for Blacks and Latinos on explicitly racial issues, rather than on implicitly racial issues. 
On explicitly racial issues, where I believe low-income and high-income Black opinion and Latino opinion will be linked, government outcomes will follow Black and Latino opinion over white opinion. On implicitly racial issues, where I believe lowincome and high-income Black and Latino opinion will diverge, government outcomes will follow higher-income citizen opinion. Racial and ethnic representation, then, will depend in part on comparative disadvantage but upon how explicit racial issues are to nonmembers.

Evaluating the Theory: Opinion Divides and Government Responsiveness (Chapter 2)

To bring the opinion and representation literatures together and examine public opinion and government responsiveness more precisely, I adapt Gilens's approach, while incorporating race, and while incorporating explicitly and implicitly racial issues. Though it is true that the questions I use cannot include the entire universe of implicitly and explicitly racial issues, they represent an improvement over the existing literature. They represent a considerable improvement over Griffin and Newman (2008), who do examine both race and income, but examine only spending preferences, and without differentiating at all between explicitly and implicitly racial issues. The potential importance of race and income in respondent opinion is recognized here, and the potential differential impact of these differences across different types of racial issues is included.

Opinion predictions: Based on the literature, I predict that low-income opinions will be more likely to be united on implicitly racial issues, regardless of respondent race. However, race, not income, will be more likely to be the binding force on issues of an explicitly racial nature. 
Representation predictions: Next, following Gilens's (2012) lead, I will ascertain whether the policy changes referred to in the questions occurred. I believe that government response to both African American and Latino opinion will be more likely on explicitly racial issues than on implicitly racial issues. This exploration moves beyond the racial and ethnic politics literature on opinion differences to include responsiveness, and moves beyond the responsiveness literature to include race and, if I am right, narrowly construed racial group representation.

There is a potential, and crucial, critique of this approach in my case. Why would responsiveness to the minority be found or desirable in a government built on majority rule? Gilens found that, perhaps paradoxically in a government based upon majority rule, the high-income individuals in the minority were responded to more so than the rest of the individuals in the country, when opinions diverged by income level. Similarly, I am predicting and arguing that united Black opinion and Latino opinion will be more likely to win out, defying majority rule, on explicitly racial issues only. On implicitly racial issues, where I believe income level's role will reassert itself, I am predicting low-income individuals of all races will be more likely to lose the representation game. In essence, then, I believe majority rule breaks down in both cases, but in different ways on issues that are explicitly and implicitly racial.

From a measurement standpoint, however, this is an important criticism. A lack of responsiveness at the national level may miss crucial responsiveness at the individual representative level. I handle this valid criticism in the next chapter, by examining responsiveness to low-income Black and Latino opinion at the level of individual representatives. 
Evaluating the Theory: Racialization and Substantive Versus Descriptive Representation (Chapter 3)

In my second research chapter, Chapter 3 of the dissertation, I reevaluate opinion divides on racialized issues at the district level, examining individual behavior, rather than Congressional institutional responsiveness. When population demographics and representative race are considered, does the theory of narrowness in racial policy representation hold? Do we witness increased activism on behalf of Blacks and Latinos by Black and Latino members of Congress on both explicitly and implicitly racial issues?

Further, where does income come into all of this? When opinions of high-income African Americans or Latinos diverge from low-income African Americans or Latinos, what happens? Swain (1995) argues that the wealthy African American representatives who get elected are no more like their African American constituents than are wealthy white representatives. Tate (2003) disagrees with Swain (1995) that African American representatives are just as different from their African American constituents as white representatives. In her mind, the Black experience is a similarity that crosses wealth differences.

Extending my theoretical lens to this debate, based on Gilens's (2012) findings about the power of income level, I largely side with Swain. To make sure I heed warnings of Grose (2011), Minta (2011), Minta and Sinclair-Chapman (2013), and Tate (2003), who argue against using only roll call data in measuring the influence of descriptive representation, which ignores other important forms of legislative responsiveness, I examine sponsorship behavior to explore this question. In both voting behavior and sponsorship behavior, I believe representatives, including Black and Latino 
representatives, exhibit narrow racial representation that does not account for the most economically disadvantaged citizens of their states.

\section{Evaluating the Theory: Oversight Behavior (Chapter 4)}

I approach oversight behavior differently. Specifically, I investigate whether the presence of African American and Latino members on congressional committees increases committee oversight of explicitly and implicitly racial issues. Kastellec (2013) has shown that the presence of African American justices on appellate courts affects those court's rulings on affirmative action - an explicitly racial issue. Does the same hold for congressional committee oversight? What about on implicitly racial issues?

\section{$\underline{\text { PREVIEW OF FINDINGS AND CONCLUSION }}$}

My findings in Chapter 2 show white opinion varies more dramatically by income than Black and Latino opinion, but income is still a meaningful driver of difference among Blacks and Latinos, on both implicitly and explicitly racial issues. In addition, the findings indicate neither explicitly or implicitly racial government outputs occur as they do because of racial group opinion, at any income level. However, Blacks and Latinosparticularly low-income Blacks and Latinos-were more desirous of change on implicitly racial issues relative explicitly racial issues in the dataset, and their opinions had no relationships with government responding or not responding to the desire for change. Whites, meanwhile, were more desirous of change on explicitly racial issues versus implicitly racial issues in the dataset, and their opinions did not seem to drive government activity or lack of it, either. The lack of activity in Congress over the years covered in the dataset (2006-2012) means further examination of this finding is necessary, but it is important to remember that big changes did happen during that time, and that low-income 
Black and/or Latino opinion did not seem to be the reason why, even when change occurred and was positive for low-income Blacks and Latinos (e.g., health care).

I investigated what did drive a low-income Latino "win" in Congress in Chapter 3. My findings indicated that for individual members voting in Congress, party matters more than the demographic composition of their district, suggesting that party, rather than constituent opinion, may drive responsiveness to low-income Black and Latino desires on implicitly racial issues. This continued to be true for sponsorship behavior; their race impacted sponsorship behavior for African Americans and Latinos in Congress on an explicitly racial issue (immigration), but not on the implicitly racial issue (Iraq withdrawal), support for which was even higher among Blacks and LAtinos. Though Chapter 3 utilized a small sample, it lends cautious credence to the idea that drivers of responsiveness are not opinions of low-income Blacks and Latinos or legislator race on implicitly racial issues, even when policies ultimately serve what low-income Blacks and Latinos desire, and even when one looks beyond voting.

Chapter 4 shows that African American and Latino membership on committees influenced the occurrence of explicitly racial hearings held before the $103^{\text {rd }}$ Congress, and the volume of implicitly racial hearings held during and after the $103^{\text {rd }}$ Congress. The size of the African American and Latino coalition in Congress mattered only after the inauguration of the $103^{\text {rd }}$ Congress, and only for the occurrence of explicit, rather than implicit, oversight. This finding supports the notion that descriptive representation matters when one looks at service beyond roll call voting (Grose 2011), but suggests it may not matter uniformly across issue types and congressional governance structures. 
Data challenges have limited our ability to understand the ways in which government fails, or does not fail, disadvantaged Blacks and Latinos. My dissertation explores racial and ethnic representation and its depth or superficiality from a variety of different angles, including opinion, collective government responsiveness, individual legislator responsiveness, and oversight, engaging multiple literatures. It suggests representation of and responsiveness to low-income Blacks and Latinos may be more null than narrow, and that the ability to solve that problem by simply adding more African American and Latino members to Congress may be limited. In total, this project shows that racialization of issues is important for opinion, for legislator voting and sponsorship, and for oversight, and represents the beginning of a better understanding of the dynamics of representation for our most disadvantaged citizens. 


\section{INTRODUCTION}

\section{CHAPTER TWO}

Racial group consciousness, and group interests, affect opinion (e.g., Dawson 1995), and affect opinion differently depending upon the nature of issue. This occurs not only due to language and framing, but also due to issues' substantive relevance for individuals (e.g. Kinder and Winter 2001; Sanchez 2006; White 2007). For example, though many issues are or can be "racialized" through language and framing (White 2007), issues that are substantively and explicitly related to race, such as affirmative action, tend to elicit stronger responses from members of racial groups than do issues that are substantively but only implicitly related to race, such as social welfare policy (Bobo and Kluegel 1993; Kinder and Winter 2001; Sanchez 2006; Valentino, Hutchings, and White 2002).

Income level also has a strong effect on a variety of policy opinions. As Gilens (2012) demonstrates, higher income and lower income individuals tend to see policy options differently. This is true not only in policy areas that would seem obvious, such as economic and social welfare policy, but also in areas that might be unexpected, such as religious issues.

Most datasets used to study opinion and opinion differences have very low sample sizes of Black and Latino respondents, meaning it is difficult to know how much the role of income matters for opinion within these groups, and when group consciousness is a stronger driver of opinion. Still, we know Black and Latino opinion is not "monolithic" (Orey, Craemer, and Price 2013). Intersectional identities, such as identities that exist at the intersection of racial categorization and income level, affect which policies are most important to studied groups and individuals (Strolovitch 2007). 
Finally, again largely due to sample size issues, we do not know how the intersection of race and income might (or might not) affect government responsiveness specifically on racially-salient issues, though Griffin and Newman (2008) have argued that government is more responsive to Blacks and Latinos (regardless of income) on racially-salient issues, despite what majority opinion desires.

In this chapter, I assess racial and intersectional opinion differences on raciallysalient issues, across a continuum from implicitly to explicitly racial. Though the findings on opinion conform to the expectations in many ways, there are some surprises. Opinion differences by race are pervasive, but not a given, sometimes not even for explicitly racial issues. African American opinion is rarely split along income lines, but Latinos exhibit important differences along income lines, even for explicitly racial issues. These findings serve as reminder of the importance of better sampling of all racial groups, and avoiding the assumption that findings about mostly white respondent opinion apply to all racial groups' opinions in the same way.

In addition, I examine how policy preferences by income, race, and race and income affect representation on implicitly and explicitly racial issues. Counter to my “narrow representation" theory, and also counter to Gilens's (2012) findings and Griffin and Newman's (2008) findings, government responsiveness on racially-salient issues of all types does not seem to vary due to income-driven, racially-driven, or income- and racially-driven opinion differences.

\section{$\underline{\text { RACIAL GROUP CONSCIOUSNESS AND OPINION }}$}

Opinion splits between Blacks, Latinos, and whites are pervasive. Explanations

for these differences range from group consciousness (Dawson 1995) to income, political 
principles, or immigrant status (e.g., Kinder and Winter 2001; Sanchez 2006). Others note how the role of these predictors varies with the nature of the issue (e.g., Kinder and Winter 2001; Sanchez 2006; Tate 1993; White 2007). The differences between Black, Latino, and white attitudes are especially pronounced on explicitly racial issues, which are obviously racial and include such issues as affirmative action and immigration. Differences are more nuanced on implicitly racial issues, which affect higher proportions of Blacks and Latinos than whites but are nevertheless not explicitly racial, such as poverty, welfare, and crime (e.g., Bobo and Kluegel 1993; Kinder and Winter 2001; Mendelberg 2001; Rabinovitz 2009; Sanchez 2006; White 2007). Gilens (2012), meanwhile, points out the strong role of income in opinion.

Though intersectional identities affect opinion (Strolovitch 2007); that is, identities formed at the intersection of race, gender, and income, due to sample size problems, the differing role of income and race is not fully understood. Neither is the role of income for Blacks and Latinos understood for issues of varying racialization, implicit and explicit.

\section{REPRESENTATION AND GROUP OPINION}

Gilens (2012) studies opinion splits between individuals of high and low income using different datasets looking for public opinion questions that offer "support" or "oppose" response options. Gilens compares income groups across their support or opposition, and looks to see where the government acts or doesn't act within four years. Where high-income and low-income respondents disagree on policy options, Gilen finds government responds more to the desires of high-income respondents. Gilens does not separate issues along any racial category, though, or group issues into explicitly or 
implicitly racial categories. Moreover, he does not divide respondents by race. I will take his approach to assessing opinion and representation wins, but will do so while making these differentiations.

Griffin and Newman (2008) try to rectify this problem, and they examine both respondent income and race. Their analysis yields a surprising finding: Black and Latino respondents "win" representation on racially salient issues of all kinds, perhaps because, as Griffin and Newman suspect, they are more interested in and focused on such issues than are others whose opinions may diverge from theirs. Griffin and Newman rely on respondents' spending preferences, rather than examining their opinions on specific policy issues as Gilens does. This makes measuring true opinion and requisite responsiveness or lack of it difficult. Many people, for example, might say they approve of an increase in education spending (Murphy 2014; Scott 2012). One could say the government is responsive to those people if the next year's budget increases education spending. But is someone who desires a fifty percent increase in education spending well-served by a ten percent increase in education spending? Furthermore, most people are in favor of generalities like "more money for education." Differences of opinion are more likely when topics like racial integration, standardized testing, or curricula are examined—even if those same topics lead to requisite increases in education spending. Equally problematic is that Griffin and Newman do not distinguish between implicitly and explicitly racial issues.

Does the power of income in representation success which Gilens uncovers continue to assert itself in racially salient issues, explicit and implicit? Measuring Black and Latino preferences more precisely, and taking care to differentiate between different 
types of racial salience, do Griffin and Newman's findings about the relationships between opinion and representation on racially salient issues hold?

\section{HYPOTHESES}

Extending the literature to my own examination, I make the following predictions.

The literature shows Blacks and Latinos tend to exhibit differences in opinion from whites on a variety of issue areas, particularly racialized issues (e.g., Bobo and Kluegel 1993; Dawson 1995; Kinder and Winter 2001; Rabinovitz 2009; Sanchez 2006; Tate 1993; White 2007). Therefore:

Opinion hypothesis 1: Racial group opinions, without consideration for group income levels, will exhibit significant differences on substantively racial issues, both implicit and explicit.

Studies and experiments demonstrate the importance of framing racially substantive issues in how whites and nonwhites view the issues. Issues with explicitly racial frames tend to elicit substantially less support from whites (Bobo and Kluegel 1993; Kinder and Winter 2001; White 2007). Therefore, I hypothesize:

Opinion hypothesis 2: Racial group opinions, without consideration for group income levels, will be farther apart on explicitly racial issues than they are on implicitly racial issues.

Dawson (1995) believes that income does not matter for linked fate: high-income African Americans tend to be just as supportive of racially-salient issues as low-income African Americans. Meanwhile, Gilens (2012), without focusing on race, finds a major impact of income-level upon opinion on issues related to social welfare. Low-income respondents are much more supportive of social welfare measures than high-income 
respondents. Social welfare issues are often implicitly racial issues because higher proportions of Blacks and Latinos, compared to whites, tend to be low-income (e.g., Bobo and Kluegel 1993; Kinder and Winter 2001; White 2007). I believe the power of income versus race on implicitly racial issues may be dynamic. To test the interacting role of income and race on implicitly and explicitly racial issues, I predict the following:

Opinion hypothesis 3: Opinions of low-income respondents, whether Black, Latino, or white, will be more likely to be closer together on implicitly than explicitly racial issues. This means the opinions of low-income Blacks, whites, and Latinos will be closer to one another on implicitly racial issues than they are for explicitly racial issues. Thus, I predict that for low-income individuals, income overcomes race on implicitly racial issues only.

Opinion hypothesis 4: Opinions of low-income respondents, whether Black, Latino, or white, will be more likely to be closer to one another on implicitly racial issues than are opinions of high-income respondents, across racial categories, on implicitly racial issues. This means the opinions of low-income African Americans, whites, and Latinos will be closer together on implicitly racial issues than the opinions of highincome African Americans, whites, and Latinos on implicitly racial issues. Therefore, I am testing whether racial considerations reassert their strength when differentiating between high-income individuals of different racial categories, on implicitly racial issues.

Opinion hypothesis 5: Race, not income, will be more likely to be the binding force for respondents on issues of an explicitly racial nature. That is, respondents across 
all income levels within racial categories will exhibit more unified opinions on explicitly racial issues than they do on implicitly racial issues. ${ }^{2}$

Gilens (2012) demonstrates unexpected cases where low-income and high-income opinion differs, yet the low-income respondent view wins on policy. This tends to occur where interest group activity is high, making policies highly salient, such as in the area of Social Security and the failed proposal to privatize it. Griffin and Newman (2008) argue that Blacks and Latinos achieve similar levels of responsiveness on policy areas that are racially salient, without differentiating implicitly and explicitly racial policies. Applying these findings to more specific racially salient policies, I predict the following:

Representation hypothesis 1: The relationships between Black and Latino imputed preferences and government responsiveness will be significant for explicitly racial but not implicitly racial issues. I believe racial salience will matter for responsiveness only where policies are explicitly racial, because such racial salience is clearer.

Representation hypothesis 2: The relationships between Black and Latino group preferences differentiated by income group and government responsiveness will be significant for explicitly racial but not implicitly racial issues. I believe that the significance between responsiveness and explicitly racial policies only will continue into any differences by income exhibited by Black and Latino respondents.

\section{DATA AND METHOD}

\section{Gathering Questions}

\footnotetext{
2 None of these hypotheses should be read as suggesting variation of opinion among respondents across issue areas is unexpected. After all, I aim to avoid "monolithic" assumptions about opinions among minority respondents when research shows this is not the case (e.g., Orey, Craemer, and Price 2013). Rather, I am simply testing when opinions might be closer, or farther apart, though still varied, within racial and income categories.
} 
Harvard's Cooperative Congressional Election Study (CCES) (Ansolabehere 2006-2012) is one of the few studies with a sample size that provides large numbers of Black and Latino respondents. Large numbers of each racial group were a necessity to enable an examination of opinion difference by income level, within those racial groups. I used the 2006, 2008, 2010, and 2012 CCES datasets.

As Gilens (2012) does, I gathered questions which aim to measure opinion based on favor/oppose responses to policy questions. These questions had to provide dichotomous choices, be specific enough to enable a reasonable assessment of whether change occurred, and be within the permissible range of federal government action (Gilens 1374-1375). For example, a dichotomous question about whether voter ID should be required at the polls was perfect in its policy substance, but so far, this is a state-level issue, so the question was excluded. Like Gilens, I permitted multiple questions on the same issue area. I agree with Gilens that including multiple looks at the same issue provides a better measure of long-term preferences, and offers a chance to avoid or capture framing issues. In addition, some issues remain relevant or even become higher on the policy agenda as the years pass (Gilens 1403-1404). Issues like climate change, immigration, and healthcare reform remained important throughout the period of time under study. Beyond Gilens's arguments for including multiple questions on the same issue, I add that the time period I am studying represents a change from a white Republican president to an African American Democratic president, and President Obama took up many of the issues included here. Tesler (2010) shows us that racial resentment became conflated with opinions on many issues once President Obama—and Democrats associated with him—-took them up. Therefore, measuring opinions on these 
issues that straddle both presidencies should aim to examine opinion stability for that reason alone.

Unlike Gilens, for each dataset, I included only those favor/oppose questions on issues that the literature tells us may be implicitly or explicitly racial. Explicitly racial questions were easy to select from the dataset, and I used news articles to confirm whether an issue might plausibly be considered implicitly racial, within the range set by the literature. This yielded a dataset of 48 questions. With such a small set of questions, this must be considered an early and cursory examination, but as small sample sizes currently do not permit a fuller examination, it is a step in the right direction. A full list of questions, question wording, and the reasoning for why they are arguably and potentially substantively important to Blacks and Latinos is available in Appendix A.

\section{Imputing Preferences}

I followed Gilens's approach for imputing group preferences, but added in race instead of just using income variations. Gilens's approach begins with assigning all respondents "an income score equal to the percentile midpoint for their income group based on the income distribution from their survey" (Gilens 2012,1455). That is, using different income categories on provided surveys, one calculates the percentage of respondents that fall within each income category. Then, each group is assigned income group midpoint scores based on the top and bottom percentiles for each group. For example, take African American respondents in the lowest income category for African Americans in 2006. They comprise 14 percent of all African American respondents, or those falling between the first and fourteenth percentile for income, so the income midpoint score for the lowest-income African Americans in 2006 is 0.075. This 
procedure was followed to create income midpoints for African Americans, Latinos, and whites.

After rescoring incomes based on relative percentages, these income midpoint variables were used as predictors of policy preference to obtain imputed preferences for each racial-income grouping. Estimating imputed preferences is done with a quadratic function, using income midpoint values and income midpoint values squared ${ }^{3}$ as predictors for logistic regressions for each of the 48 two-option (favor or oppose) survey questions. In my case, unlike Gilens's, this is done within racial groups: imputed preferences by income for African Americans, Latinos, and whites. This approach imputes preferences by income within racial groups for each of the 48 policy areas. For example, the income midpoints for African American income groupings in 2006 are $0.075,0.34,0.68$, and 0.91 . These values were used to create an ordered income midpoint variable for African Americans. Next came a logit analysis for each policy. As an illustration, I took minimum wage, where the dependent variable is support or opposition for an increase in the minimum wage, and the income midpoint variables and income midpoint variables squared as predictors. Predicted probabilities gathered following this exercise indicates levels of support for increasing the minimum wage among African Americans at each income level. This procedure was followed for every one of the 48 policy areas, and every income midpoint within each racial category.

In addition, I created imputed preferences by race regardless of income by using basic racial group dummies as predictors instead of income midpoint variables. The

\footnotetext{
${ }^{3}$ Gilens (2005) includes the squared income variable to "smooth out some of the noise inherent in estimating preferences for population subgroups with limited numbers of responses" (783).
} 
imputed preferences obtained from this exercise provide a measure of policy preference for respondents at different income percentiles and within different racial groups.

\section{Coding Government Outcomes}

Gilens's government responsiveness measure is also used here, with small changes. Gilens codes responsiveness rather than inaction as the outcome if activity on the issue, defined as Congress passing a law in that issue area and the president signing it, occurs within four years of the survey question (Gilens 2012 1433). In most cases, I use the four-year responsiveness method, but in a few cases, survey questions specified a tighter timeline. For example, in 2006 and 2008 respondents were asked if they favored withdrawing troops from Iraq within a year (2006) or within 180 days (2008). True responsiveness to such questions seems to demand action within the specified timeframe, so I respected that when it occurred. ${ }^{4}$

In addition, I did not use Congress passing a bill and the president signing it as the only mode of national government responsiveness, as Gilens does. The cry for the Affordable Care Act to grant religious exemptions from covering birth control in employee insurance policies was heard. However, it received its response not through legislation, but through the Courts (Wheaton College v. Burwell, Burwell v. Hobby Lobby Stores Inc.) and rule changes (U.S. Department of Health and Human Services), exempting some religious employers from covering contraception in their health insurance plans (Denniston 2015; Sobel et al 2015). Similarly, though ending affirmative action would likely require a constitutional amendment, when seventy-five percent of whites and sixty-seven percent of the entire public is against affirmative action in certain

\footnotetext{
4 This may raise concerns; however, there is no "time" variable in the analysis itself, only whether government responded or not $(0,1)$.
} 
surveys (Jones 2013), an amendment does not seem to be an overwhelming hurdle to cross. In addition, the Supreme Court has sent very mixed signals over the years on this issue. In the 1990s, the Court tightened affirmative action in set-aside programs (City of Richmond v. Croson), federal affirmative action programs (Adarand Constructors v. Pena), and education (Hopwood v. Texas ) (“Affirmative Action"), but some programs are upheld, as recently as this year (Fisher v. University of Texas). It is not implausible that Congress might attempt change. Therefore, for the purposes of this study, the lack of change on this issue constitutes nonresponsiveness to those who would like to see change.

Keeping these adapted parameters in mind, for each issue, as Gilens does, I used Congressional Quarterly reports and news articles to determine whether or not responsiveness to desired changes occurred. A full account of this research and coding is included in Appendix B.

\section{Measuring Government Responsiveness}

Finally, I looked for relationships between income level imputed opinion, racial group imputed opinion, and income level/racial group intersectional imputed opinion and government outcomes. Again, following Gilens (2012), this is done with logit regressions, using the government outcome variable for each policy area as the dependent variable (where 0 is no change and 1 is change), and with the imputed preference variables by income and race and by race alone as the predictors. To avoid collinearity problems, these were run separately by predictor: logit regressions using the government 
outcome variable as the dependent variable and imputed preferences at each income level and each racial grouping were done individually, as recommended by Gilens. ${ }^{5}$

To ensure this question was examined from every angle, I ran these analyses on the entire dataset of questions together, without differentiating by level of racialization; separately with just implicit questions and just explicit questions; and separately for questions that the imputed opinion analyses revealed to be significantly racialized. I defined "significantly racialized" as those questions that exhibited at least a two-unit difference in opinion between racial groups using Gilens's coding scheme.

\section{$\underline{\text { RESULTS }}$}

\section{Racialization of opinion}

Table 1 displays imputed preferences by race, and the size of the difference, using Gilens's coding scheme. Table 1 displays the differences between opinions, and figures 1 and 2 use the absolute values of these differences. The values in the table and the continuum are derived from the imputed preference percentage coding scheme Gilens (2012) uses:
Between $45 \%$ and $55 \%=0$
Over $55 \%$ or under $45 \%=+1 /-1$
Over $60 \%$ or under $40 \%=+/-2$
Over $65 \%$ or under $35 \%=+/-3$
Over $75 \%$ or under $25 \%=+/-4$
Over $85 \%$ or under $15 \%=+/-5$

For example, 14 percent of African Americans favored ending public school and emergency room access for immigrants in the country illegally. Using Gilens's coding scheme, this percentage of support is coded as -5 (as it is under 15 percent). 37 percent whites favored this policy proposal; this percentage is coded as -2 (as it is below 40

\footnotetext{
${ }^{5}$ I discussed this via email with Gilens himself.
} 
percent support but above 35 percent support). Therefore, the difference between African Americans' opinions on this issue minus whites' opinions on this issue is - 3 (recorded in Table 1), and the absolute value of the difference between these groups' opinions is 3 (recorded in Figure 1). The use of this coding permits easier comparisons and helps quickly demonstrate not only significant differences but the magnitude of that significance. This procedure is followed to compare across racial groups, across income groups, and across racial and income groups.

As seen in Table 1, there is racialization in opinion by racial group throughout this dataset. The opinions on questions in this dataset indeed display a continuum quality. Most issues I included as potentially racial are racialized in actuality, but to differing degrees. Figures 1 and 2 below summarize the findings in Table 1, displaying results on a continuum to demonstrate the varying sizes of opinion difference.

Opinion hypothesis 1 predicted that racial group opinions, without consideration for group income levels, would exhibit significant differences on substantively racial issues, both implicit and explicit. This is largely the case, although for both African Americans and Latinos there are a few issues where opinions do not differ dramatically. For African Americans, this includes only CAFTA. Overall, Latino and white opinion exhibits more nonracialized issues, including bailing out the banks, TARP, the Ryan budget bill, and the Tax Hike Prevention Act.

These surprises, and the results that went as expected, confirm the idea of a continuum of racialization, the diversity of opinion, and the fact that substantively important policies are perceived as substantively important at varying rates. 


\section{Table 1: Racialization of Opinion}

\begin{tabular}{|c|c|c|c|c|c|}
\hline \multirow[b]{2}{*}{ Policy } & \multicolumn{3}{|c|}{ Racial Category } & \multicolumn{2}{|c|}{ Difference } \\
\hline & African American & Latino & White & $\begin{array}{l}\text { African American- } \\
\text { White }\end{array}$ & $\begin{array}{l}\text { Latino- } \\
\text { White }\end{array}$ \\
\hline \multicolumn{6}{|l|}{ Implicit Issues } \\
\hline Partial Birth Abortion Ban & 0 & 0 & 1 & $-1 * * *$ & $-1 * * *$ \\
\hline CAFTA & -3 & 0 & -3 & 0 & $3 * * *$ \\
\hline Housing & 4 & 2 & 0 & $4 * * *$ & $2 * * *$ \\
\hline Bank Bailout & -2 & -3 & -3 & $1 * * *$ & $0 * * *$ \\
\hline Carbon Tax & -3 & -3 & -4 & $1 * * *$ & $1 * * *$ \\
\hline TARP & -1 & -3 & -3 & $2 * * *$ & $0 * * *$ \\
\hline Financial Reform & 5 & 4 & 2 & $3 * * *$ & $2 * * *$ \\
\hline $\begin{array}{l}\text { American Recovery and } \\
\text { Reinvestment Act }\end{array}$ & 4 & 2 & -1 & $5^{* * * *}$ & $3 * * *$ \\
\hline $\begin{array}{l}\text { American Clean Energy } \\
\text { and Security Act }\end{array}$ & 4 & 3 & 0 & $4 * * *$ & $3 * * *$ \\
\hline $\begin{array}{l}\text { Exemption for birth } \\
\text { control }\end{array}$ & -4 & -3 & -1 & $-3 * * *$ & $-2 * * *$ \\
\hline Affordable Care Act & 5 & 3 & 0 & $5 * * *$ & $3 * * *$ \\
\hline $\begin{array}{l}\text { Affordable Care Act } \\
\text { Repeal }\end{array}$ & -3 & -2 & 0 & $-3 * * *$ & $-2 * * *$ \\
\hline Ryan Bill & -5 & -4 & -4 & $-1 * * *$ & $0 * *$ \\
\hline Simpson Bowles & 0 & 0 & 0 & $0^{* * * *}$ & 0 \\
\hline Middle Class Tax Cut Act & 1 & 1 & 2 & $-1 * * *$ & $-1 * * *$ \\
\hline Tax Hike Prevention Act & -4 & -3 & -3 & $-1 * * *$ & $0 * * *$ \\
\hline Climate Change & 3 & 3 & 0 & $3 * * *$ & $3 * * *$ \\
\hline Gun Control & 3 & 1 & -1 & $4 * * *$ & $2 * * *$ \\
\hline CHIP & 5 & 4 & 3 & $2 * * *$ & $1 * * *$ \\
\hline $\begin{array}{l}\text { Comprehensive Health } \\
\text { Care }\end{array}$ & 5 & 2 & 0 & $5 * * *$ & $2 * * *$ \\
\hline Minimum Wage & 5 & 5 & 3 & $2 * * *$ & $2 * * *$ \\
\hline $\begin{array}{l}\text { Social Security } \\
\text { Privatization }\end{array}$ & -1 & 0 & 1 & $-2 * * *$ & $-1 * *$ \\
\hline Iraq Withdrawal & 5 & 3 & 0 & $5 * * *$ & $3 * * *$ \\
\hline Explicit Issues & & & & & \\
\hline
\end{tabular}




\begin{tabular}{|c|c|c|c|c|c|}
\hline $\begin{array}{l}\text { Ending automatic } \\
\text { birthright citizenship }\end{array}$ & -5 & -4 & -1 & $-4 * * *$ & $-3 * * *$ \\
\hline $\begin{array}{l}\text { Banning illegal } \\
\text { immigrants from using } \\
\text { ER }\end{array}$ & -5 & -4 & -2 & $-3 * * *$ & $-2 * * *$ \\
\hline Affirmative Action & 5 & 1 & -3 & $8 * * *$ & $4 * * *$ \\
\hline $\begin{array}{l}\text { Grant legal status to } \\
\text { illegal immigrants }\end{array}$ & 1 & 2 & -2 & $3 * * *$ & $4 * * *$ \\
\hline $\begin{array}{l}\text { Fine businesses who hire } \\
\text { illegal immigrants }\end{array}$ & 0 & -2 & 3 & $-3 * * *$ & $-5 * * *$ \\
\hline Increase border patrols & 0 & -2 & 2 & $-2 * * *$ & $-4 * * *$ \\
\hline $\begin{array}{l}\text { Allow police to question } \\
\text { suspected "illegals" }\end{array}$ & -4 & -4 & 0 & $-4 * * *$ & $-4 * * *$ \\
\hline
\end{tabular}

Note:

Table shows imputed level of support for policies by race.

Coding values for imputed preferences:

Between $45 \%$ and $55 \%=0$

Over $55 \%$ or under $45 \%=+1 /-1$

Over $60 \%$ or under $40 \%=+/-2$

Over $65 \%$ or under $35 \%=+/-3$

Over $75 \%$ or under $25 \%=+/-4$

Over $85 \%$ or under $15 \%=+/-5$

*=indicates significance in two-sample tests of proportion; African American vs. White, and Latino vs.

White

$* * *=$ proportion differed significantly by race, $\mathrm{p}<0.001$

$* *=$ proportion differed significantly by race, $\mathrm{p}<0.01$

$*=$ proportion differed significantly by race, $\mathrm{p}<0.05$ 
Figure 1: The Continuum of Racialized Issues--African American and White Opinion

\begin{tabular}{|c|c|c|c|c|c|c|c|c|}
\hline \multirow[b]{2}{*}{$\begin{array}{l}0 \\
\text { Nonracial }\end{array}$} & \multicolumn{8}{|c|}{$\begin{array}{l}\text { African American - White Opinion: Racialization Continuum } \\
\text { (Absolute Value of Imputed Preference Difference) }\end{array}$} \\
\hline & 1 & 2 & 3 & 4 & 5 & 6 & 7 & 8 \\
\hline -CAFTA & $\begin{array}{l}\text {-Partial Birth } \\
\text {-Bank bailout } \\
\text {-Carbon tax } \\
\text {-Ryan budget } \\
\text {-Tax cut } \\
\text {-Tax prevention }\end{array}$ & $\begin{array}{l}\text {-TARP } \\
\text {-CHIP } \\
\text {-Min. wage } \\
\text {-Social Sec. } \\
\text {-Borders }\end{array}$ & $\begin{array}{l}\text {-Fin. Reform } \\
\text {-Birth control } \\
\text {-ACA repeal } \\
\text {-Immigrant-ER } \\
\text {-Climate change } \\
\text {-Amnesty } \\
\text {-Fine hiring illegals }\end{array}$ & $\begin{array}{l}\text {-Housing assistance } \\
\text {-ACESA } \\
\text {-Birthright citizenship } \\
\text {-Gun control } \\
\text { - Police question }\end{array}$ & $\begin{array}{l}\text {-ARRA } \\
\text {-ACA } \\
\text {-Healthcare } \\
\text {-Iraq Withdrawal }\end{array}$ & & & -Affirmative Action \\
\hline
\end{tabular}

Figure 2: The Continuum of Racialized Issues: Latino and White Opinion

Latino - White Opinion: Racialization Continuum

(Absolute Value of Imputed Preference Difference)

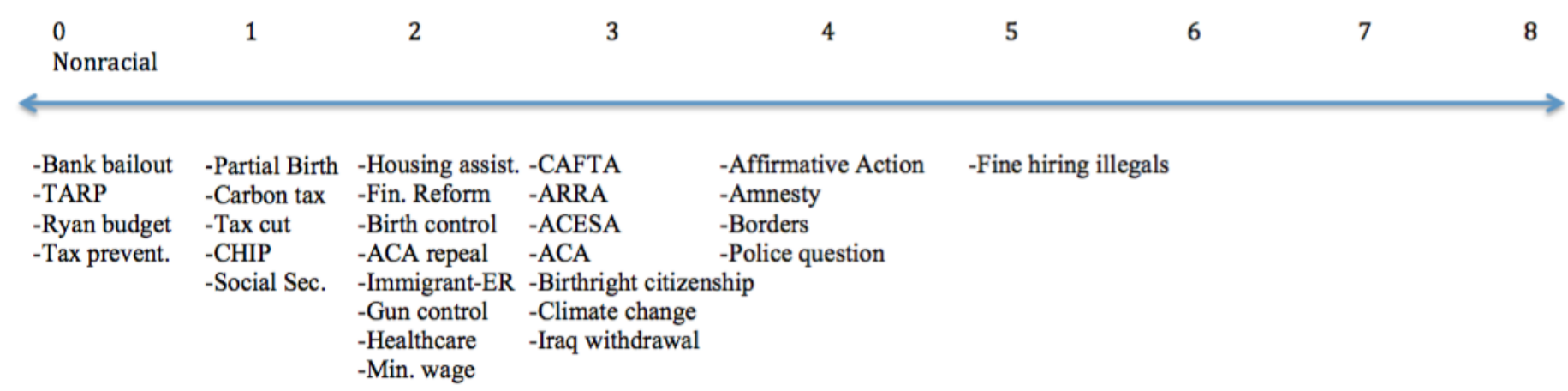

Note: The figures display where issues fall on a number line displaying the size of the difference in imputed preferences, AA-White and Latino-White. 
Opinion hypothesis 2 predicted that racial group opinions would be farther apart on explicitly racial issues than they are on implicitly racial issues. This is generally the case. African American opinion and white opinion is farthest apart, by far, on affirmative action, and Latino and white opinion is farthest apart on affirmative action, and immigration-relevant issues such as fining businesses who hire illegal immigrants, granting legal status to illegal immigrants, increasing border patrols, and allowing the police to question anyone suspected of being here illegally.

There are two surprises here. One is, while ending automatic birthright citizenship and banning illegal immigrants from using the ER and public schools elicit very different responses in Latinos and whites, issues like CAFTA, the American Recovery and Reinvestment Act, the American Clean Energy and Security Act, the Affordable Care Act, climate change, Iraq withdrawal, housing assistance, financial reform, exempting companies from birth control, repealing the Affordable Care act, increasing gun control measures, and increasing the minimum wage elicit just as different a response from members of these groups. Another is that, though affirmative action is the biggest opinion divider between African Americans and whites by far, many immigration issues still cause greater differences in opinion between African Americans and whites than do issues like partial birth abortion, the bank bailout, a carbon tax, the Tax Hike Prevention Act, and the Middle Class Tax Cut Act. One would not necessarily expect African Americans to be more supportive of, for example, amnesty, than whites are, but this is the case. 
Overall, a wide variety of issues are racialized, but in differing degrees, and explicitly racial issues do tend to elicit the biggest differences in responses by Blacks, Latinos, and whites, suggesting that a racialization continuum is a useful concept.

\section{Income and Opinion}

Opinion hypothesis 3 predicted that opinions of low-income respondents, whether Black, Latino, or white, would be more likely to be closer together on implicitly than explicitly racial issues. Opinion hypothesis 4 predicted that opinions of low-income respondents, whether Black, Latino, or white, would be more likely to be closer to one another on implicitly racial issues than are opinions of high-income respondents, whether Black, Latino, or white, on implicitly racial issues. Table 2 supports both these hypotheses.

Table 2: Differences in Mean Opinion between Groups by Income Level

\begin{tabular}{|c|c|c|c|}
\hline & $\begin{array}{l}\text { Implicitly Racial } \\
\text { Issues }\end{array}$ & $\begin{array}{l}\text { Explicitly Racial } \\
\text { Issues } \\
\text { (Affirmative } \\
\text { Action) }\end{array}$ & $\begin{array}{l}\text { Explicitly Racial } \\
\text { Issues } \\
\text { (Immigration) }\end{array}$ \\
\hline $\begin{array}{l}\text { Low-Income African Americans } \\
\text { and Low-Income Whites } \\
\text { High-Income African }\end{array}$ & 1.41 & 6.75 & 2.91 \\
\hline $\begin{array}{l}\text { Americans and High-Income } \\
\text { Whites }\end{array}$ & 3.03 & 8.00 & 2.36 \\
\hline $\begin{array}{l}\text { Low-Income Latinos and Low- } \\
\text { Income Whites }\end{array}$ & 1.16 & 5.25 & 4.45 \\
\hline $\begin{array}{l}\text { High-Income Latinos and High- } \\
\text { Income Whites }\end{array}$ & 1.47 & 3.75 & 2.73 \\
\hline \multicolumn{4}{|c|}{$\begin{array}{l}\text { Note: Table shows the mean difference of opinion between groups, by income level, in different } \\
\text { policy areas, using Gilen's coding scheme for imputed preferences: } \\
\text { Between } 45 \% \text { and } 55 \%=0 \\
\text { Over } 55 \% \text { or under } 45 \%=+1 /-1 \\
\text { Over } 60 \% \text { or under } 40 \%=+/-2 \\
\text { Over } 65 \% \text { or under } 35 \%=+/-3 \\
\text { Over } 75 \% \text { or under } 25 \%=+/-4 \\
\text { Over } 85 \% \text { or under } 15 \%=+-5\end{array}$} \\
\hline
\end{tabular}


Again using Gilens's (2012) coding scheme for imputed preference percentages, and this time examining the average absolute values of differences, it's plain that lowincome African Americans and low-income whites are much closer to one another on implicitly racial issues than explicitly racial issues. The same is true for low-income Latinos and low-income whites. The finding holds not only for racial issues that are especially relevant for the racial group being examined, but also if one is examining explicitly racial issues related to immigration and low-income African American versus low-income white opinion, or affirmative action and low-income Latino versus lowincome white opinion.

In addition, low-income opinions are closer together on implicitly racial issues than are high-income opinions on implicitly racial issues, particularly when comparing the average difference between low-income whites and African Americans and the average difference between high-income whites and African Americans. The difference is less pronounced for low-income Latino/white opinion and high-income Latino/white opinion, but still there and in the expected direction. ${ }^{6}$

Opinion hypothesis 5 predicted that respondents across all income levels within racial categories would exhibit more unified opinions on explicitly racial issues than they do on implicitly racial issues. The findings here are more mixed, as shown in Tables 3 and 4, and Figures 3 and 4. Table 3 shows that for African Americans, there are few issues where income midpoint variables are significant. For African Americans, of the 48

${ }^{6}$ Obviously, averages mask heterogeneity in difference across issues in the dataset, and this table is not meant to suggest opinion differences will always conform to this trend on every single implicitly/explicitly racial issue comparison. As averages can be particularly blunt for comparing differences where outliers might be possible, Appendix $\mathrm{C}$ provides a comparison of medians. The findings in support of opinion hypotheses 3 and 4 hold. 
questions examined, there are just a handful of issues where income levels create a significant difference in opinion. And, as can be seen in Figure 3, using Gilens's coding scheme for imputed opinions, where significant differences exist, in African American opinion according to income level, they tend to be small in magnitude. The biggest areas of difference were support for a repeal of the Affordable Care Act, and support for the Middle Class Tax Cut Act. This level of agreement across all issues, implicit or no, was not expected. Moreover, African American opinion on explicitly racial issues, including affirmative action in two of the four datasets, demonstrated differences according to income in some cases, also counter to expectations.

As Table 4 shows, differences in opinion according to income level among Latinos were more common, and, as can be seen in Figure 4, they were more likely to be of a higher magnitude. That said, differences in opinion according to income level were far from universal on implicitly racial issues, and more importantly, differences in opinion according to income level happened repeatedly on explicitly racial issues. Latinos are divided on policies related to immigration based on their income level.

This is quite different from the patterns demonstrated in white opinion (see Appendix D). Income levels yield significant differences in opinion for all issues in the dataset except for the Tax Hike Prevention Act. Further, white opinion across income levels is indeed closer on explicitly racial issues than it is on implicitly racial issues.

Table 3: African American Opinion by Lowest and Highest Income Percentiles

\begin{tabular}{|r|l|c|c|c|}
\hline \multirow{2}{*}{ Year } & Policy & \multicolumn{2}{|c|}{ African American--Income } & $\begin{array}{c}\text { Difference } \\
\text { Highest- } \\
\text { Lowest }\end{array}$ \\
\hline 2006 & Minimum Wage1 & Lowest & Highest & 0 \\
\hline 2008 & Minimum Wage & 5 & 5 & 0 \\
\hline 2006 & Minimum Wage 2 & 5 & 5 & 0 \\
\hline
\end{tabular}




\begin{tabular}{|c|c|c|c|c|}
\hline 2006 & Climate Change & 4 & 4 & 0 \\
\hline 2010 & Climate Change & 3 & 4 & 1 \\
\hline 2012 & Climate change & 3 & 4 & 1 \\
\hline 2006 & PartialBirth & 1 & 0 & 1 \\
\hline 2012 & BirthControlEx & -4 & -4 & 0 \\
\hline 2006 & Social Security & -1 & -2 & 1 \\
\hline 2008 & Social Security & 0 & -1 & 1 \\
\hline 2006 & Iraq & 5 & 4 & 1 \\
\hline 2008 & Iraq & 5 & 5 & 1 \\
\hline 2006 & CAFTA** & -3 & -2 & 1 \\
\hline 2008 & CHIP & 5 & 5 & 0 \\
\hline 2010 & CHIP** & 5 & 5 & 0 \\
\hline 2008 & Housing* & 4 & 4 & 0 \\
\hline 2010 & BankBail & -1 & -1 & 0 \\
\hline 2010 & TARP & -1 & 0 & 1 \\
\hline 2010 & Financial Reform*** & 5 & 5 & 0 \\
\hline 2008 & $\begin{array}{l}\text { Comprehensive } \\
\text { Healthcare }\end{array}$ & 5 & 5 & 0 \\
\hline 2010 & $\begin{array}{l}\text { Comprehensive } \\
\text { Healthcare }\end{array}$ & 5 & 4 & 1 \\
\hline 2012 & ACA & 4 & 5 & 1 \\
\hline 2012 & ACARepeal** & -2 & -4 & 2 \\
\hline 2008 & CarbonTax & -2 & -3 & 1 \\
\hline 2010 & ACESA* & 4 & 4 & 0 \\
\hline 2010 & Gun Control & 3 & 3 & 0 \\
\hline 2012 & Gun Control & 4 & 4 & 0 \\
\hline 2010 & ARRA & 4 & 4 & 0 \\
\hline 2012 & RyanBill & -5 & -5 & 0 \\
\hline 2012 & SimpBowles & -2 & 0 & 2 \\
\hline 2012 & MidTax** & 0 & 2 & 2 \\
\hline 2012 & TaxHike* & -4 & -5 & 1 \\
\hline 2006 & AffrmAct & 5 & 5 & 0 \\
\hline 2008 & AffrmAct* & 4 & 5 & 1 \\
\hline 2010 & AffrmAct* & 4 & 4 & 0 \\
\hline 2012 & AffrmAct* & 4 & 5 & 1 \\
\hline 2006 & Immigration & 1 & 0 & 1 \\
\hline 2010 & FineBusinesses & 0 & 4 & 4 \\
\hline 2012 & FineBusinesses & -2 & 0 & 2 \\
\hline 2010 & GrantStatus & 0 & 1 & 1 \\
\hline 2012 & GrantStatus & 2 & 3 & 1 \\
\hline 2010 & BorderPatrols** & 0 & 0 & 0 \\
\hline 2012 & BorderPatrols & -1 & 0 & 1 \\
\hline
\end{tabular}




\begin{tabular}{|l|l|l|l|l|}
2010 & PoliceQuestion & -4 & -4 & 0 \\
\hline 2012 & PoliceQuestion & -4 & -5 & 1 \\
\hline 2012 & ER/Schools** & -5 & -4 & 1 \\
\hline 2012 & AutoCitizenship & -5 & -4 & 1 \\
\hline
\end{tabular}

Note:

Table shows differences in opinion among African Americans, using coding levels for imputed preferences devised by Gilens.:

Between $45 \%$ and $55 \%=0$

Over $55 \%$ or under $45 \%=+1 /-1$

Over $60 \%$ or under $40 \%=+/-2$

Over $65 \%$ or under $35 \%=+/-3$

Over $75 \%$ or under $25 \%=+/-4$

Over $85 \%$ or under $15 \%=+/-5$

P-values indicate where differences in opinion among African Americans, by income, are significant in logit regressions, where the dependent variable is support or opposition for a policy among African Americans, and income levels among African Americans are the predictors.

$* * *=\mathrm{p}<0.001$

$* *=\mathrm{p}<0.01$

$*=\mathrm{p}<0.05$ 
Figure 3: African American Opinion: Magnitude of Significant Differences

Absolute Value of Differences in Opinion:

African Americans at Highest and Lowest Income Levels

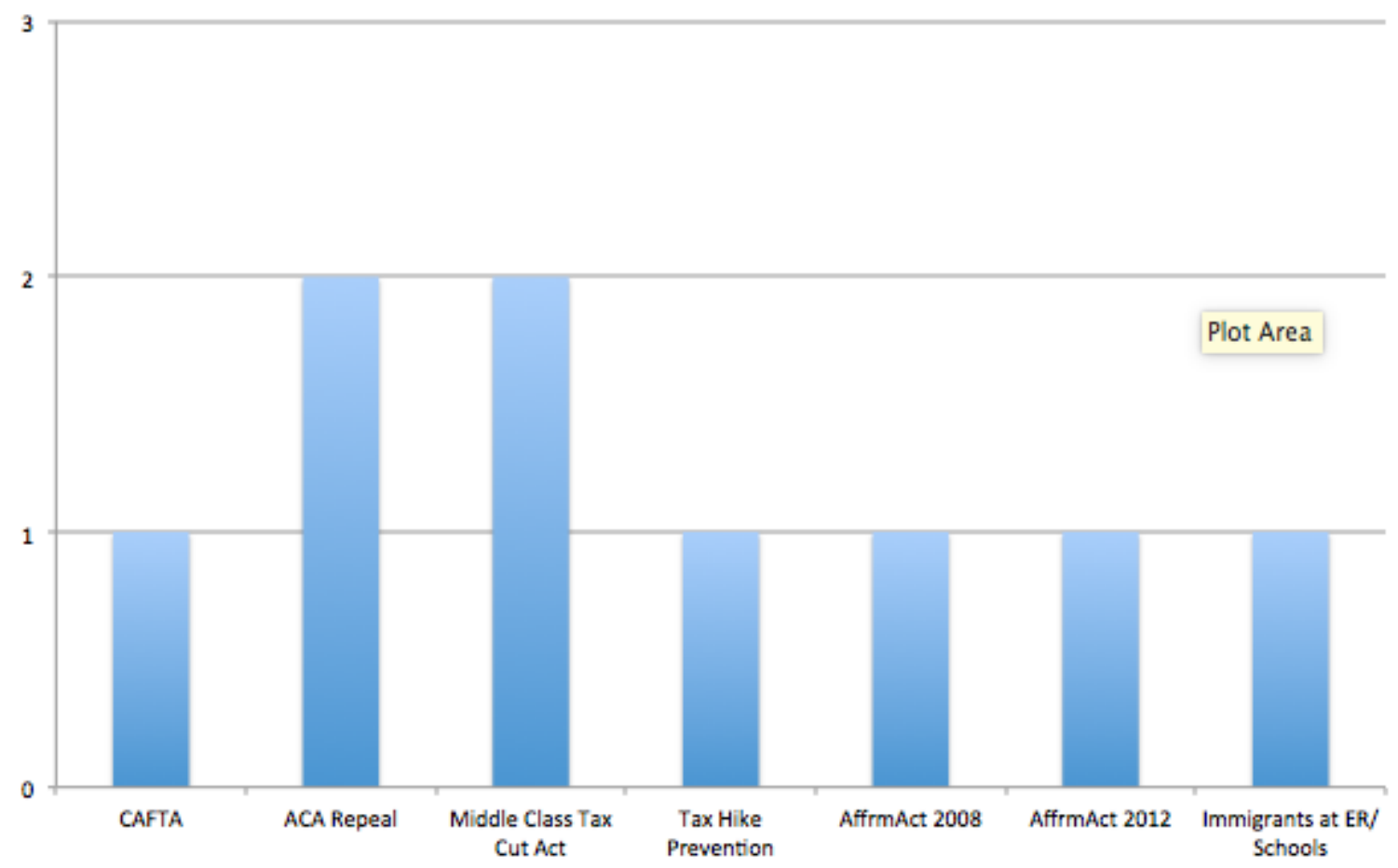

Note: Figure 3 displays the size of all significant differences in opinion between high-income and low-income African Americans. The values are derived from Gilens's coding scheme. 
Table 4: Latino Opinion by Lowest and Highest Income Percentiles

\begin{tabular}{|c|c|c|c|c|}
\hline \multirow[b]{2}{*}{ Year } & \multirow[b]{2}{*}{ Policy } & \multicolumn{2}{|c|}{$\begin{array}{l}\text { Latino--Income } \\
\text { Percentile }\end{array}$} & \multirow{2}{*}{$\begin{array}{c}\text { Difference } \\
\text { Highest- } \\
\text { Lowest }\end{array}$} \\
\hline & & Lowest & Highest & \\
\hline 2006 & Minimum Wage1** & 5 & 4 & 1 \\
\hline 2008 & Minimum Wage & 5 & 4 & 1 \\
\hline 2006 & Minimum Wage $2 *$ & 5 & 4 & 1 \\
\hline 2006 & Climate Change & 4 & 3 & 1 \\
\hline 2010 & Climate Change & 3 & 2 & 1 \\
\hline 2012 & Climate change & 3 & 3 & 0 \\
\hline 2006 & PartialBirth & 0 & -1 & 1 \\
\hline 2012 & BirthControlEx & -3 & -3 & 0 \\
\hline 2006 & Social Security & 0 & 0 & 0 \\
\hline 2008 & Social Security & 0 & 0 & 0 \\
\hline 2006 & Iraq & 4 & 2 & 2 \\
\hline 2008 & Iraq* & 4 & 1 & 3 \\
\hline 2006 & CAFTA* & -3 & -2 & 1 \\
\hline 2008 & CHIP* & 5 & 4 & 1 \\
\hline 2010 & CHIP & 5 & 5 & 0 \\
\hline 2008 & Housing & 4 & 0 & 4 \\
\hline 2008 & BankBail & -3 & -3 & 0 \\
\hline 2010 & TARP $* * *$ & 0 & -3 & 3 \\
\hline 2010 & Financial Reform & 4 & 3 & 1 \\
\hline 2008 & $\begin{array}{l}\text { Comprehensive } \\
\text { Healthcare }\end{array}$ & 3 & 1 & 2 \\
\hline 2010 & $\begin{array}{l}\text { Comprehensive } \\
\text { Healthcare* }\end{array}$ & 3 & 1 & 2 \\
\hline 2012 & ACA & 3 & 2 & 1 \\
\hline 2012 & ACARepeal & -2 & -2 & 0 \\
\hline 2008 & CarbonTax & -3 & -3 & 0 \\
\hline 2010 & ACESA & 4 & 2 & 2 \\
\hline 2010 & Gun Control & 3 & 2 & 1 \\
\hline 2012 & Gun Control & 3 & 3 & 0 \\
\hline 2010 & ARRA & 3 & 0 & 3 \\
\hline 2012 & RyanBill & -4 & -4 & 0 \\
\hline 2012 & SimpBowles & -1 & 1 & 2 \\
\hline 2012 & MidTax & 0 & 3 & 3 \\
\hline 2012 & TaxHike & -3 & -4 & 1 \\
\hline 2006 & AffrmAct & 2 & 1 & 1 \\
\hline 2008 & AffrmAct & 3 & 0 & 3 \\
\hline
\end{tabular}




\begin{tabular}{|c|l|c|c|c|}
\hline 2010 & AffrmAct & 3 & 0 & 3 \\
\hline 2012 & AffrmAct & 3 & 1 & 2 \\
\hline 2006 & Immigration*** & 4 & 3 & 1 \\
\hline 2010 & FineBusinesses & -3 & 1 & 4 \\
\hline 2012 & FineBusinesses & -3 & 0 & 3 \\
\hline 2010 & GrantStatus* & 3 & 1 & 2 \\
\hline 2012 & GrantStatus & 3 & 2 & 1 \\
\hline 2010 & BorderPatrols*** & -3 & 0 & 3 \\
\hline 2012 & BorderPatrols* & -3 & -1 & 2 \\
\hline 2010 & PoliceQuestion*** & -5 & -3 & 2 \\
\hline 2012 & PoliceQuestion & -5 & -4 & 1 \\
\hline 2012 & ER/Schools & -5 & -4 & 1 \\
\hline 2012 & AutoCitizenship & -5 & -4 & 1 \\
\hline
\end{tabular}

Note:

Table shows differences in opinion among Latinos, using coding levels for imputed preferences devised by Gilens.:

Between $45 \%$ and $55 \%=0$

Over $55 \%$ or under $45 \%=+1 /-1$

Over $60 \%$ or under $40 \%=+/-2$

Over $65 \%$ or under $35 \%=+/-3$

Over $75 \%$ or under $25 \%=+/-4$

Over $85 \%$ or under $15 \%=+/-5$

P-values indicate where differences in opinion among Latinos, by income, are significant in logit regressions, where the dependent variable is support or opposition for a policy among Latinos, and income levels among Latinos are the predictors.

$* * *=\mathrm{p}<0.001$

$* *=\mathrm{p}<0.01$

$*=\mathrm{p}<0.05$ 
Figure 4: Latino Opinion: Magnitude of Significant Differences

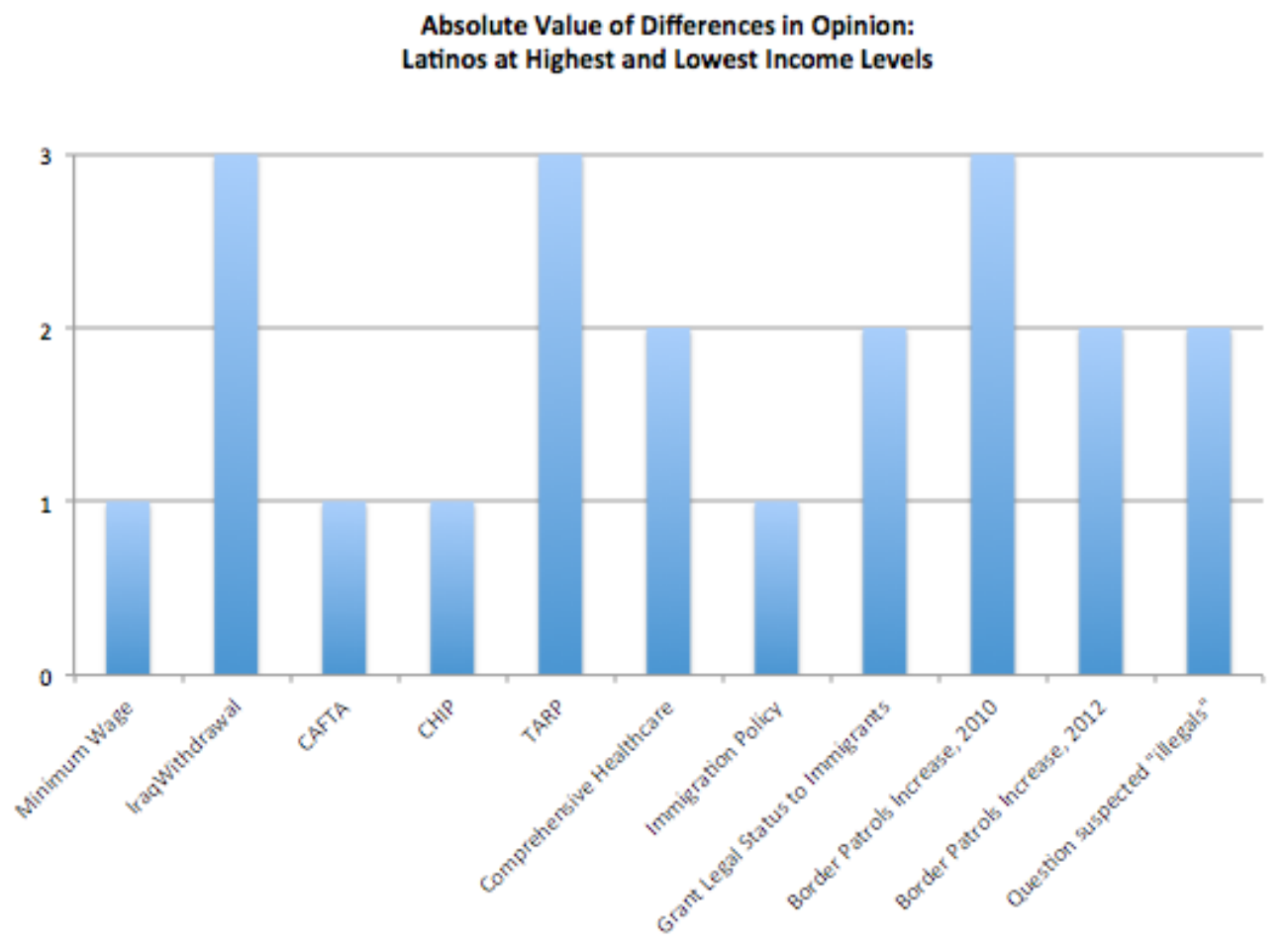

Note: Figure displays the size of all significant differences in opinion between high-income and low-income Latinos. The values are derived from Gilens's coding scheme.

\section{Representation and Racialized Issues}

Representation hypothesis 1 predicted that the relationships between Black and Latino group imputed preferences and government responsiveness would be significant for explicitly racial but not implicitly racial issues, and representation hypothesis 2 predicted that the relationships between combined racial and income imputed preferences and government responsiveness would be significant for explicitly racial but not implicitly racial issues. The findings do not support either of these conclusions, as seen in Tables 5 and 6. 


\begin{tabular}{|c|c|c|c|}
\hline $\begin{array}{c}\text { Income Percentile } \\
\text { Predictor }\end{array}$ & All Observations & Implicit Variables & Explicit Variables \\
\hline $\begin{array}{l}\text { Income, } \mathbf{1 0}^{\text {th }} \\
\text { Coefficient } \\
\text { (Standard Error) } \\
\text { P-Value }\end{array}$ & $\begin{array}{c}2.15 \\
(1.74) \\
0.11\end{array}$ & $\begin{array}{c}2.19 \\
(2.01) \\
0.14\end{array}$ & $\begin{array}{c}3.16 \\
(5.64) \\
0.29\end{array}$ \\
\hline $\begin{array}{l}\text { Income, } \mathbf{3 0}^{\text {th }} \\
\text { Coefficient } \\
\text { (standard error) } \\
\text { P-Value }\end{array}$ & $\begin{array}{c}2.44 \\
(2.01) \\
0.11\end{array}$ & $\begin{array}{c}2.06 \\
(2.31) \\
0.19\end{array}$ & $\begin{array}{c}4.40 \\
(4.94) \\
0.19\end{array}$ \\
\hline $\begin{array}{l}\text { Income, } \mathbf{7 0}^{\text {th }} \\
\text { Coefficient } \\
\text { (standard error) } \\
\text { P-Value }\end{array}$ & $\begin{array}{c}1.76 \\
(2.28) \\
0.22\end{array}$ & $\begin{array}{c}0.96 \\
(2.71) \\
0.36\end{array}$ & $\begin{array}{c}3.44 \\
(4.31) \\
0.21\end{array}$ \\
\hline $\begin{array}{l}\text { Income, 90 } \\
\text { Coefficient } \\
\text { (standard error) } \\
\text { P-Value }\end{array}$ & $\begin{array}{c}0.72 \\
(2.57) \\
0.39\end{array}$ & $\begin{array}{c}-0.17 \\
(3.16 \\
0.48\end{array}$ & $\begin{array}{c}2.28 \\
(4.57) \\
0.31\end{array}$ \\
\hline $\begin{array}{l}\text { African American, } \mathbf{1 0}^{\text {th }} \\
\text { Coefficient } \\
\text { (standard error) } \\
\text { P-Value }\end{array}$ & $\begin{array}{l}1.58 \\
(1.17) \\
0.089\end{array}$ & $\begin{array}{c}2.31 \\
(1.61) \\
0.08\end{array}$ & $\begin{array}{c}0.51 \\
(2.99) \\
0.43\end{array}$ \\
\hline
\end{tabular}




\begin{tabular}{|c|c|c|c|}
\hline $\begin{array}{l}\text { African American, } \mathbf{3 0}^{\text {th }} \\
\text { Coefficient } \\
\text { (standard error) } \\
\text { P-Value }\end{array}$ & $\begin{array}{c}1.66 \\
(1.15) \\
0.08\end{array}$ & $\begin{array}{c}2.37 \\
(1.60) \\
0.07\end{array}$ & $\begin{array}{c}0.8 \\
(3.00) \\
0.4\end{array}$ \\
\hline $\begin{array}{l}\text { African American, } \mathbf{7 0}^{\text {th }} \\
\text { Coefficient } \\
\text { (standard error) } \\
\text { P-Value }\end{array}$ & $\begin{array}{c}1.72 \\
(1.17) \\
0.07\end{array}$ & $\begin{array}{c}2.55 \\
(1.67) \\
0.07\end{array}$ & $\begin{array}{c}0.75 \\
(3.07) \\
0.40\end{array}$ \\
\hline $\begin{array}{l}\text { African American, } \mathbf{9 0}^{\text {th }} \\
\text { Coefficient } \\
\text { (standard error) } \\
\text { P-Value }\end{array}$ & $\begin{array}{c}0.27 \\
(1.40) \\
0.4\end{array}$ & $\begin{array}{c}1.35 \\
(2.07) \\
0.26\end{array}$ & $\begin{array}{c}-0.01 \\
(3.15) \\
0.5\end{array}$ \\
\hline $\begin{array}{l}\text { Latino, } \mathbf{1 0}^{\text {th }} \\
\text { Coefficient } \\
\text { (standard error) } \\
\text { P-Value }\end{array}$ & $\begin{array}{l}0.24 \\
(1.3) \\
0.43\end{array}$ & $\begin{array}{c}2.46 \\
(1.87) \\
0.09\end{array}$ & $\begin{array}{c}-7.86 \\
(5.53) \\
0.08\end{array}$ \\
\hline $\begin{array}{l}\text { Latino, } \mathbf{3 0}^{\text {th }} \\
\text { Coefficient } \\
\text { (standard error) } \\
\text { P-Value }\end{array}$ & $\begin{array}{l}0.31 \\
(1.5) \\
0.42\end{array}$ & $\begin{array}{c}2.24 \\
(2.09) \\
0.14\end{array}$ & $\begin{array}{c}-6.00 \\
(4.25) \\
0.08\end{array}$ \\
\hline $\begin{array}{l}\text { Latino, } \mathbf{7 0}^{\text {th }} \\
\text { Coefficient } \\
\text { (standard error) } \\
\text { P-Value }\end{array}$ & $\begin{array}{c}0.14 \\
(1.77) \\
0.47\end{array}$ & $\begin{array}{c}1.72 \\
(2.27) \\
0.22\end{array}$ & $\begin{array}{c}-5.67 \\
(4.307) \\
0.09\end{array}$ \\
\hline
\end{tabular}




\begin{tabular}{|c|c|c|c|}
\hline $\begin{array}{l}\text { Latino, } \mathbf{9 0}^{\text {th }} \\
\text { Coefficient } \\
\text { (standard error) } \\
\text { P-Value }\end{array}$ & $\begin{array}{c}-1.88 \\
(2.39) \\
0.22\end{array}$ & $\begin{array}{c}1.05 \\
(3.35) \\
0.38\end{array}$ & $\begin{array}{c}-6.08 \\
(4.6) \\
0.09\end{array}$ \\
\hline $\begin{array}{l}\text { White, } \mathbf{1 0}^{\text {th }} \\
\text { Coefficient } \\
\text { (standard error) } \\
\text { P-Value }\end{array}$ & $\begin{array}{c}2.27 \\
(1.82) \\
0.11\end{array}$ & $\begin{array}{c}1.79 \\
(2.07) \\
0.19\end{array}$ & $\begin{array}{c}4.12 \\
(4.16) \\
0.16\end{array}$ \\
\hline $\begin{array}{l}\text { White, } \mathbf{3 0}^{\text {th }} \\
\text { Coefficient } \\
\text { (standard error) } \\
\text { P-Value }\end{array}$ & $\begin{array}{c}2.02 \\
(1.98) \\
0.15\end{array}$ & $\begin{array}{c}1.27 \\
(2.41) \\
0.3\end{array}$ & $\begin{array}{c}3.39 \\
(3.45) \\
0.16\end{array}$ \\
\hline $\begin{array}{l}\text { White, } \mathbf{7 0}^{\text {th }} \\
\text { Coefficient } \\
\text { (standard error) } \\
\text { P-Value }\end{array}$ & $\begin{array}{c}1.34 \\
(2.15) \\
0.27\end{array}$ & $\begin{array}{c}0.16 \\
(2.83) \\
0.48\end{array}$ & $\begin{array}{c}2.87 \\
(3.33) \\
0.19\end{array}$ \\
\hline $\begin{array}{l}\text { White, } \mathbf{9 0}^{\text {th }} \\
\text { Coefficient } \\
\text { (standard error) } \\
\text { P-Value }\end{array}$ & $\begin{array}{c}0.51 \\
(2.46) \\
0.42\end{array}$ & $\begin{array}{c}-0.86 \\
(3.33) \\
0.4\end{array}$ & $\begin{array}{c}2.05 \\
(3.67) \\
0.29\end{array}$ \\
\hline
\end{tabular}

Note: The table displays coefficients, standard errors, and p-values for logistic regressions with government response $(0,1)$ as the dependent variable, where income and income*race variables are predictors. The first column displays regression results with all policies included, the second displays regression results with just implicit policies included, and the third displays regression results with just explicit policies included. 
Table 6: Responsiveness and Race

\begin{tabular}{|c|c|c|c|c|}
\hline Racialization Type & Opinion Predictor & $\begin{array}{c}\text { Implicit \& Explicit } \\
\text { Issues }\end{array}$ & Implicit Only & Explicit Only \\
\hline \multirow{2}{*}{$\begin{array}{l}\text { African American- } \\
\text { White }\end{array}$} & $\begin{array}{l}\text { African American } \\
\text { Coefficient } \\
\text { (Standard Error) } \\
\text { P-Value }\end{array}$ & $\begin{array}{c}1.67 \\
(1.26) \\
0.09\end{array}$ & $\begin{array}{c}3.49 \\
(2.39) \\
0.07\end{array}$ & $\begin{array}{c}0.74 \\
(3.10) \\
0.41\end{array}$ \\
\hline & $\begin{array}{l}\text { White } \\
\text { Coefficient } \\
\text { (Standard Error) } \\
\text { P-Value }\end{array}$ & $\begin{array}{c}1.70 \\
(2.59) \\
0.26\end{array}$ & $\begin{array}{c}-0.64 \\
(4.26) \\
0.44\end{array}$ & $\begin{array}{c}3.26 \\
(3.52) \\
0.18\end{array}$ \\
\hline \multirow[t]{2}{*}{ Latino-White } & $\begin{array}{l}\text { Latino } \\
\text { Coefficient } \\
\text { (Standard Error) } \\
\text { P-Value }\end{array}$ & $\begin{array}{c}-0.95 \\
(1.88) \\
0.31\end{array}$ & $\begin{array}{c}1.41 \\
(3.21) \\
0.33\end{array}$ & $\begin{array}{c}-6.63 \\
(4.52) \\
0.07\end{array}$ \\
\hline & $\begin{array}{l}\text { White } \\
\text { Coefficient } \\
\text { (Standard Error) } \\
\text { P-Value }\end{array}$ & $\begin{array}{c}0.925 \\
(2.64) \\
0.36 \\
\end{array}$ & $\begin{array}{c}-4.00 \\
(5.22) \\
0.22 \\
\end{array}$ & $\begin{array}{c}3.26 \\
(3.52) \\
0.18 \\
\end{array}$ \\
\hline
\end{tabular}

Note: The table displays coefficients, standard errors, and p-values for logistic regressions with government response $(0,1)$ as the dependent variable, where race variables are predictors. These tests were performed on policy areas that displayed different opinions by race, at least 2 or more apart in Figures 1 and 2 . Where African American and white opinion differed, I checked for a relationship between government outcomes and group opinion for both African Americans and whites. I then did the same for Latinos and whites. 
Despite running the representation analysis in a variety of ways ${ }^{7}$, in no case is racial group opinion or racial group*income level opinion significantly related to government outcomes on either implicitly or explicitly racial issues. Griffin and Newman (2008) found that Blacks and Latinos "win" on issues substantively important to them, which would include both implicitly and explicitly racial issues, but when opinion is measured by support or opposition for specific policies, rather than by preferred spending levels as Griffin and Newman do, there is no relationship between racial group opinion and the questions included in this dataset. Counter to what I expected, there is also no relationship between Black and Latino group opinion and government responsiveness on explicitly racial issues only. The same is true even when one isolates those issues with "significant" opinion differences by race (where white opinion vs. Black or Latino opinion differs by 2 or more using the Gilens coding scheme).

It's important to note that the maintenance of the status quo, rather than change, may sometimes reflect preferences. For example, African Americans and Latinos prefer keeping affirmative action to getting rid of it, and affirmative action remains policy despite threats to it. However, on other explicitly racial issues and implicitly racial issues where change is desired by Blacks and Latinos, no relationship between opinion and responsiveness is found within the studied timeframe.

This theme continues when examining opinion by income level. Whether one looks at the entire dataset, just implicitly racial issues, or just explicitly racial issues, there is no relationship between imputed preferences among Blacks and Latinos and government outcomes on racialized issues. Without differentiating by race, Gilens (2012)

\footnotetext{
${ }^{7}$ Including zero-inflated negative binomial models.
} 
found income level opinions mattered for a wide variety of issues. Differences in opinion according to income level within racial groups do not seem to have such force in government outcomes, at least not for racialized issues.

Another piece of news, though I made no predictions in this area, is that there also appears to be no relationship between white opinion or white income group opinions and government outcomes on racialized issues. I considered this possibility particularly because of the inclusion of affirmative action in the dataset. African Americans and Latinos prefer the status quo, and the status quo, despite threats and white opinion on the issue, has been maintained in the area of affirmative action. However, I still found no relationship between African American and Latino opinion on explicitly racial issues overall. Though whites prefer change in this policy area, change has not occurred, and white opinion and government output do not have a relationship. This continued throughout the dataset. Whatever drives government output on these issues, it is not racial group opinion or income. Not even majority opinion appears to matter.

\section{DISCUSSION AND CONCLUSION}

This examination must be considered the start of this discussion rather than the end of it, because the number of issues included in the dataset is small. Nevertheless, it is intriguing that variables that seem to exhibit surprising force in other studies (income differences in Gilens 2012, and racial group opinion in Griffin and Newman 2008) do not here. In addition, the findings on opinion differences confirm Black and Latino opinion behaves differently than white opinion. Income differences appear to matter much less for Latinos and Blacks than it does for whites, which is important to keep in mind while considering findings about income and government responsiveness. When government 
responds to high-income white opinion, these findings show, it is being particularly unresponsive to African Americans and Latinos of many income levels, not just lowincome whites. However, neither is Black or Latino opinion wholly unified by income, even on those issues where strong group consciousness would seem most indicated.

Four potential conclusions are of note. First, research to date tends to examine trends based on white opinion only. Income is a powerful force upon white opinion, but less so for Black and Latino opinion, at least within the area of racialized policy. Second, much research comes to conclusions about Black and Latino opinion with small sample sizes, with unknown variations in income, gender, age, or other possibly important components of identity. This examination indicates the danger of doing this. Lowincome Latinos and high-income Latinos, for example, view some issues very differently. Third, while African Americans and Latinos tend more liberal than whites, this is not always the case. Most interestingly, this is not always the case on issues where it would seem most indicated, such as immigration policy and high-income Latinos. Finally, we often expect that intensity of opinion can make up for disadvantage. For example, gun rights supporters win on debates over gun control, not because they hold the majority opinion, but because they are the most vocal. Pro-lifers retain a strong hold on abortion policy for the same reason. More relevant to this chapter, Griffin and Newman (2008) argue that Blacks and Latinos have unexpected representational wins on racially salient issues, even though their opinions do not represent the majority opinion. Though I expected this finding only on explicitly racial issues, I do not find it. The government does not seem predictably responsive to any group on racialized issues, not to whom 
those the issues would ostensibly seem to matter most, nor to the white majority. This is a perplexing finding indeed for a democracy.

In the next chapter, I will move to consider the behavior of individual legislators. Where income differences are indicated, do individual legislators exhibit different voting patterns based on the number of low-income Blacks and Latinos in their district? By race? What about sponsorship behavior? 


\section{$\underline{\text { INTRODUCTION }}$}

\section{CHAPTER THREE}

Focusing on "government" as a body, particularly when African Americans and Latinos remain underrepresented in government as a whole (Krogstad 2015), is very different from looking at the responsiveness of individual legislators to opinion. Certainly members of Congress wish to be reelected (Mayhew 1974), so constituent opinion matters to them. Whose opinions matter, though? On which issues? Miller and Stokes (1963) argued that the nature of the issue determines whether members of Congress act as majority-following delegates or more independent-minded trustees. The members of Congress Fenno (1978) studied focused on their electoral supporters over and above their entire districts. Similarly, Kingdon (1977) argued that legislators may or may not worry about constituent opinion, depending on how salient and/or contentious issues are within districts.

Scholars studying descriptive representation and its effects on substantive representation add another layer: members of Congress do a better job substantively representing those who share some of their characteristics, such as race or gender, than do those who are unlike their constituents (e.g., Grose 2011; Mansbridge 1999; Tate 2003). One might assume these individuals follow a slightly different decision-making calculus, and do a better job matching the desires of disadvantaged constituents. Whether this happens, though, is far from settled, with many arguing that majority-minority districts designed to improve descriptive representation lead to "perverse effects" in the substantive policy outcomes of Congress as a whole (e.g. Lublin 1999; Lublin and Voss 2003; Schickler et al 2010), and others arguing generally well-to-do African American and Latino members of Congress are no more like their constituents than are white 
Democrats (e.g., Swain 1995). Any exploration of representation at the level of the individual legislator ought to consider the role of descriptive representation. In addition, there should be a recognition that voting on bills is not the only way to represent one's constituency (e.g., Grose 2011).

In this chapter, I bring these ideas together, examining not only the role of descriptive representation, party, and district characteristics like race and income, but also the role of varying issue types: explicitly and implicitly racial issues. I examine what drives individual member of Congress voting behavior on two implicitly racial issues. My theory of "narrow representation" anticipates narrow, or limited, responsiveness on implicitly racial issues, and that African American and Latino members of Congress may not be different from other members in this respect. They may not do better representing their likely less politically active low-income constituents than Fenno (1978) would expect of the white legislators he studied. I examine this possibility by considering voting on implicitly racial issues where low-income African American and Latino opinion differs from the opinions of majorities of low-income whites, high-income whites, and high-income African Americans and Latinos. I also consider sponsorship on explicitly and implicitly racial issues. I find evidence that Latino and African American members are differently active on explicitly racial issue sponsorships, but that implicitly racial votes and sponsorships are largely driven by party and ideology rather than race. DESCRIPTIVE REPRESENTATION $\neq$ SUBSTANTIVE REPRESENTATION?

Members of Congress respond to their constituents if they want to stay in Congress (Mayhew 1974), or respond to their constituents on issues where it is absolutely necessary (Miller and Stokes 1963; Kingdon 1977), or respond on issues that are critical 
to their re-election constituencies (Fenno 1978). Some argue there is also a need to represent nonwhite and female constituents descriptively to do a better job representing them substantively. Electing legislators that look like the members of the public improves descriptive representation, which requires that citizens be represented by people who resemble them and presumably have shared many of their life experiences (e.g., Mansbridge 1999).

If your representative looks like you, there is an assumption that the representative will share many of your perspectives and will look out for your interests in his or her legislative actions. Thus, there is some presumption that better descriptive representation will lead to better substantive representation — or better policy outcomesfor disadvantaged interests. Whether this is actually the case is strongly debated.

This debate centers on the creation of majority-minority districts as the method for achieving better descriptive representation. A majority-minority district exists where the majority of the represented in a district are Blacks or Latinos. Prior to the 1990 census, majority-minority districts were happenstance to the extent they existed at all; large numbers of African Americans in a district could theoretically improve the chances of a African American candidate. Deliberate efforts to create majority-minority districts, however, began after the 1990 census (Reeves 1997). At that time, concerns turned to avoiding intentional efforts to dilute the African American vote while drawing congressional districts. For example, previously, gerrymanderers might "crack" a racial bloc into multiple districts to reduce its influence. To avoid such efforts, the 1990 redistricting created majority-minority districts, which deliberately drew districts to increase the influence of the majority vote in that district. Later, Supreme Court cases 
(Shaw v. Reno and Miller v. Johnson) placed limitations on how majority-minority districts should be drawn, but they still exist and undeniably have led to increased numbers of African Americans and Latinos holding political office, and thus increased descriptive representation.

There is concern, however, that descriptive representation does not ensure substantive representation. This is because there are signs that, in the aggregate, majority-minority districts may potentially reduce the number of Democrats elected, leading to fewer substantive governmental outcomes Blacks and Latinos desire (e.g., Lublin 1997; Lublin and Voss 2003). At the same time, as Swain (1995) points out, Black and Latino members of Congress may look like their constituents more than white Democrats do, but they are no more like them in reality than white Democrats are. This is because they tend to be much wealthier than their constituents and have had very different life and professional experiences.

Others point out that looking at only aggregate governmental outcomes or only roll call voting is a problem, because representation can include, for example, constituent services and project delivery (e.g., Grose 2011; Tate 2003), contact with representatives (Banducci et al 2004), or agenda setting (e.g., Minta and Sinclair-Chapman 2013; Tate 2003). Finally, Tate (2003) argues that wealth does not matter: the experience of life as an African American in the U.S. crosses wealth boundaries. Problematically, taking away majority-minority or influence districts (Lublin 1997) would be tantamount to taking away descriptive representation entirely, because African Americans and Latinos still struggle to be elected in majority-white districts (Bowler and Segura 2011). 
The question of whether the promise of descriptive representation is fulfilled substantively is far from answered, and not really addressed when it comes to the differences we know exist in white, Black, and Latino opinion on implicitly versus explicitly racial issues. This chapter aims to fill this gap, and further extend my examination of this overall question. Because of the differences between descriptive and substantive representation, the relevance of both kinds of representation, the possible tradeoff between the two when the method of delivery is majority-minority districts, and the struggles still faced by African American and Latino candidates, any examination of opinion and representation is incomplete without considering legislator race, constituency characteristics, and party influences. It is also essential to consider different modes of representation. In the previous chapter, I considered only government outputs in the aggregate, without attention to individual legislator race or behavior, or to district makeup. Furthermore, I considered only action as defined by passing laws or rules, rather than constituent service, sponsorship, or oversight as Grose (2011) recommends. Here, I consider the roles of constituency, legislator characteristics, and type of legislative representation. Do these things matter for representation on racially-salient issues?

\section{DATA AND METHOD}

\section{$\underline{\text { Legislator Voting Behavior }}$}

In this chapter, responsiveness is voting in a certain way; specifically, responsiveness is voting according to the majority opinion of low-income African Americans and Latinos. ${ }^{8}$ Measuring responsiveness in this way requires an issue to

\footnotetext{
8 In the 2010 dataset (TARP), "low-income" African Americans and Latinos are those making less than $\$ 25,000$. This is 23 percent of the sample of African Americans \& 18 percent of the sample of Latinos. In the 2012 dataset (Middle Class Tax Cut Act), "low-income" African Americans and Latinos are those making less than $\$ 20,000$. This is 21 percent of African Americans \& 16 percent of Latinos in the sample.
} 
come to a vote. Congress has not voted on the explicit issues in the CCES in the years for which the data is available. Thus, I will be examining roll call behavior on implicit issues only, and, critically, on the only two issues where Congress has taken an implicitly racial issue to a vote in the CCES dataset that elicits different responses from low-income and high-income Black and Latino respondents. While one might argue that not much information can be gained from examining two policies, this is the entire universe of implicitly racial policies in the dataset that allows me to examine individual-level voting behavior, where 1) low-income African American and Latino opinion are unique from other group majority opinions, as discussed below, and 2) Congress took action by voting on the implicitly racial issue in question.

A logit analysis is used, where the dependent variable is voting "yea" or "nay" on the votes in question. I include two votes that exhibit different characteristics in respondent opinion, for the purpose of comparison: The American Taxpayer Relief Act and the vote on the Troubled Asset Relief Program. As noted in the appendix of Chapter 2, though the Middle Class Tax Cut Act did not succeed, the American Taxpayer Relief Act, which also aimed to keep Bush-era tax cuts for middle-income families, did. On this issue, based on imputed opinions gathered in the last chapter, low-income African Americans and high-income African Americans disagreed. 64 percent of high income African Americans favored the Middle Class Tax Cut Act, while only 47 percent of lowincome African Americans favored it. In addition, low-income African American and low-income white opinion differed on this issue, with 56 percent of low-income whites in favor. High-income African Americans and whites exhibited much closer opinions, with 64 percent of high-income African Americans and 63 percent of high-income whites in 
favor of the Middle Class Tax Cut Act. 51 percent of low-income Latinos and 67 percent of high-income Latinos favored it, making low-income African Americans the only group without a majority in favor. Next, I examine the 2008 Emergency Economic Stabilization Act, which created the Troubled Asset Relief Program. The only group with a majority opinion in support of TARP in the CCES survey was low-income Latinos, with 51 percent support among these respondents. This isolation of low-income African American or Latino preferences aims to determine how the decision-making calculus does, or does not, differ for African American and Latino representatives relative to white representatives. We know representatives and activists do a poor job focusing on the desires of disadvantaged constituents who are also generally not politically active (e.g., Kingdon 1977; Fenno 1978; Verba, Schlozman, and Brady 1995; Strolovitch 2007). Do African American and Latino representatives do a better job, considering we assume their shared perspective will ensure better representation (e.g., Mansbridge 1999; Tate 2003)?

For the American Taxpayer Relief Act, there are 427 observations: 171 no and 256 aye. For TARP, there are 416 observations: 148 nay and 268 yea. Though I could include another category for non-voting and use a multinomial logit model, generally those who did not vote were those who passed away, were injured (e.g., Gabrielle Giffords), or left for some other reason during the session (e.g., Anthony Weiner). For those reasons, including a non-voting category is not especially meaningful. Those who did not vote are simply dropped from the analysis, leaving only two possible values for the dependent variable.

Independent Variables 
To provide measures of district characteristics, I use the U.S. Census's American Community Study, with data by congressional district for the $112^{\text {th }}$ (for the American Taxpayer Relief Act vote) and $110^{\text {th }}$ Congresses (for the TARP vote). I include the relevant district population and the median income of the relevant population in the district. I examine African American population and income for the American Taxpayer Relief Act vote, and Latino population and income for the TARP vote. In addition to including median income for African Americans and Latinos, I include white median income, because low-income areas are often low-income for everyone. This way, I do not miss what might be responsiveness to white constituents.

In addition, I include legislator party ( $1=$ Democrat; $0=$ Republican $)$ and legislator race. For the legislator race variables, which evaluate descriptive representation, I utilize an African American $=1$ and other $=0$ dummy for the American Taxpayer Relief Act analysis, and a Latino $=1$ and other $=0$ dummy for the TARP analysis. I also include both dimensions of Poole and Rosenthal's DW-NOMINATE scores from the VoteView database to measure ideology.

The dependent variable, legislator vote, is aligned with low-income opinion in the following ways. The direction of the vote, "yea" or "nay," determines whether or not the vote aligned with low-income opinion imputed in chapter 2 ("no" among low-income African Americans for the vote on the American Taxpayer Relief Act; "yes" among lowincome Latinos for the vote on TARP). Unfortunately, though the CCES does a better job than most datasets with including respondents, it does not sample enough Black and Latino respondents to allow examination of their opinions at the state or district level, especially when those demographic divides are further split by income. Due to these data 
limitations, I must assume that these national-level opinion tendencies among lowincome Latinos and African Americans, imputed in chapter 2 and key to the interpretation of these analyses, hold at the district level.

Such assumptions can be problematic. Undoubtedly, region is a potentially meaningful determinant for opinion differences. Whether or not an issue is salient to individuals in a district is key to the decisions representatives will make (e.g., Kingdon 1978). Still, the assumption I am making is weak for the following reasons. Bowler and Segura (2011) demonstrate that Black and Latino opinion is more bound together than is white opinion. This finding is especially true for African Americans. Among Latinos, though their opinions are not as aligned as those of African Americans, many of the stronger determinants for commonality in Latino opinion, such as English proficiency, citizenship status, and nativity (Sanchez 2006) align with a major factor I am accounting for-low-income status. Assuming similarity among all African Americans and all Latinos is a common research problem I am deliberately trying to avoid. I am, rather, assuming that there will be some meaningful similarity among low-income African Americans and low-income Latinos across districts. This is not unreasonable.

Moreover, scholars make similar assumptions in other meaningful research. Gilens (2012) did not account for race, or gender, or district, or state when he examined opinions of low-income, middle-income, and high-income Americans. His findings are still important and enlightening. As discussed below, I will provide some meaningful measures for district differences, such as district-level population size and population income. Finally, Mansbridge (2003) writes that "surrogate" descriptive representation exists when a black or female representative represents Blacks and women who live 
nowhere near their districts, because Blacks and women feel represented by them. Even if there is some variation among low-income African Americans and Latinos by district, one would hope that the national-level opinion of these groups would find, if nothing else, surrogate representation among some members of Congress. This is, in part, what descriptive representation expects. While imperfect, this is a good starting place for evaluating individual legislator responsiveness to opinion.

\section{$\underline{\text { Sponsorship Behavior }}$}

To include explicitly racial issues, and to move beyond roll call behavior, I examine legislative sponsorship activity. I use the Congressional Bills Project to gather data from the $110^{\text {th }}$ Congress and $112^{\text {th }}$ Congress related to certain explicitly and implicitly racial subjects in the CCES. I use Iraq withdrawal as an implicitly racial topic. 91 percent of low-income African Americans compared to 85 percent of high-income African Americans in 2008 favored withdrawing from Iraq that year. Though, clearly, a strong majority of both income groups favored withdrawal, low-income African Americans were especially strong on this issue. Similarly, 79 percent of Latinos at the lowest income level in 2008 supported Iraq withdrawal, compared to only 58 percent of Latinos in the highest income group that year. Thus, those lawmakers sponsoring bills for Iraq withdrawal in 2008 would be particularly responsive to their low-income constituents, both Latino and African American. 66 percent of low-income whites and just 43 percent of high-income whites favored withdrawal from Iraq that year.

I use immigration as the explicitly racial topic. Though granting legal status to illegal immigrants is more popular among all Latinos than it is among whites, in 2012, it was favored by 72 percent of low-income Latinos compared to 64 percent of high-income 
Latinos. Among African Americans at different income levels, opinions are close together, and in favor of granting legal status to illegal immigrants: 64 percent of lowincome African Americans favored this policy in 2012, and 66 percent of high income African Americans did. All of these preferences are significantly higher than support for this policy among whites. 44 percent of low-income whites and 46 percent of highincome whites were in favor of granting legal status. Those legislators sponsoring bills for granting legal status to illegal immigrants are representing their low-income constituents, particularly Latinos, over and above the opinions of most white constituents.

Due to the overall low rate of member sponsorship on these issues, I approach this analysis using t-tests and two-way tests of proportion to avoid small-sample bias of a maximum likelihood estimation model. I gather sponsorships by limiting the major topic codes from the Congressional Bills Project to defense for Iraq, and immigration and labor for immigration. For Iraq withdrawal, to capture relevant bills, I simply searched for "Iraq;" for immigration, I searched for the following terms: "amnesty," "illegal immigration," "immigration reform," "legal status," "citizenship," "alien," and "dream" (because of the DREAM Act). Sponsorship behavior in these areas is included if it aligns with dominant low-income Black and Latino group opinion on these subjects, using the bill description. Each legislator is coded for the number of times he or she sponsored a bill in line with low-income Black and Latino interests on these issues, as well as whether he or she sponsored any such bills or not. Independent variables, again, include district Black and Latino size, the groups' median income, legislator race, and legislator party.

For Iraq, I include bills that explicitly discuss withdrawal, decreasing troop time there or increasing troop leave, overturning authorizations for Iraq, or limiting funds for 
the effort. I also include bills that represent an effort by a legislator to exert congressional control over executive branch activities in Iraq (e.g., "To require the President to develop a plan containing dates certain for the commencement and completion of a phased redeployment of United States Armed Forces from Iraq, and for other purposes," "To enhance congressional oversight of Operation Iraqi Freedom by requiring the President to transmit periodically to Congress a consolidated, comprehensive report to detail the terms of completion for Operation Iraqi Freedom and by requiring the President to seek to enter into a multilateral agreement to help provide for the completion of Operation Iraqi Freedom.”).

For immigration, I used a coding scheme of "openness to immigration." Again, this includes more bills than just those providing amnesty. Bills included evince a desire to assist legal immigrants and illegal immigrants in some way (excluding those specifically targeting refugees from conflicts such as Iraq and Syria, which arguably occupy a different policy space). Examples include immigration reform bills with a path to citizenship; bills that permit immigration judges to allow noncitizen parents of citizen children to stay in the U.S.; bills that allow states to cancel removal of alien students who came to the U.S. as children; bills that grant special status to certain nonimmigrants for scientific or educational achievement, or because of their parents' status (for example, as 9/11 survivors or victims, or as veterans); bills that reject keeping services from immigrants or requiring additional paperwork from them (for example, bills against requiring new Permanent Resident Cards for lawful residents, or authorizing payment from Medicare for emergency services provided to undocumented aliens, or allowing access to public schools, or helping alien children access child welfare services). 
For the sake of comparison, I also include a "closed to immigration" category; these bills work against the desires of low-income Black and Latino respondents in the CCES. It is important to control for not only policy type but the direction of responsiveness. Bill descriptions in this category tend to be more blunt. Some examples include "ending the cycle of illegal immigration in the United States," "to require those applying for...SCHIP... benefits to present documentation proving citizenship...," "to deny certain Federal funds to any institution of higher education that admits as students aliens who are unlawfully present in the United States," "to amend the Immigration and Nationality Act to deny citizenship at birth to children born in the United States of parents who are not citizens...," bills that punish crimes more severely when committed by aliens or illegal immigrants, and bills authorizing the construction of a fence or wall. Given that those legislators with large immigrant populations might be particularly likely to act either for or against immigrant interests, including both sides helps disentangle the role of legislator race and district population characteristics.

Though this coding casts a wide net, I believe even a sponsored bill that seeks slightly less than outright withdrawal for Iraq or total amnesty for illegal immigrants provides a legislator the opportunity to tell constituents who believe in both of these things that he or she is working in line with their goals. It permits me to capture responsiveness that, while perhaps not extreme enough, may represent an effort to respond to certain constituencies. Certainly, there are few enough of these bills (over the two Congresses examined, 54 Iraq bills, 33 "openness to immigration" bills, and 50 "closed to immigration" bills), to suggest there is something unusual about those who sponsor them, something beyond party, and this examination provides a look at what that 
might be. All descriptions of bill sponsorships utilized in the analysis, captured from the Congressional Bills Project dataset, are included in Appendix E for review. Appendix F lists representatives sponsoring bills, and Appendix G contains maps highlighting what states sponsoring legislators hail from.

\section{$\underline{\text { HYPOTHESES }}$}

\section{Section 1: Roll call behavior on implicitly racial issues}

\section{$\underline{\text { Hypotheses } 1 \text { and } 2}$}

Authors urging caution about the promise of descriptive representation for substantively important outcomes for African Americans and Latinos believe that Democrats of any race, and liberals, will better represent these groups than Republicans and conservatives (e.g., Lublin 1999; Lublin and Voss 2003). Therefore, I predict Democrats will be more responsive to the desires of low-income Black and Latino CCES respondents than Republicans. That is, Democrats will be less likely to vote "yes" on the American Taxpayer Relief Act (aligning them with the majority opinion among lowincome African Americans) and more likely to vote "yes" on the Troubled Asset Relief Program (aligning them with the majority opinion among low-income Latinos). Correspondingly, I predict liberals will be less likely to vote "yes" on the American Taxpayer Relief Act, and more likely to vote "yes" on the Troubled Asset Relief Program.

\section{Hypothesis 3}

Other scholars note that descriptive representation is often important for effective representation (e.g., Grose 2011; Mansbridge 1999; Tate 2003). If this is the case here, one would expect that African American legislators will be less likely to vote "yes" on 
the American Taxpayer Relief Act, and Latino legislators will be more likely to vote "yes" on the Troubled Asset Relief Program.

\section{Hypothesis 4}

If members want to be re-elected, one would assume that they would vote as constituents in their districts desire (e.g., Mayhew 1974). If this is true across members of Congress, legislators with large low-income Black or Latino populations should show no significant differences in their responsiveness to the desires of these respondents. As the district African American population increases and African American median income decreases, voting "yes" on the American Taxpayer Relief Act will become less likely. As the district Latino population increases and Latino median income decreases, voting “yes" on TARP will become more likely.

Section 2: Sponsorship behavior on explicitly and implicitly racial issues

\section{Hypothesis 5}

If authors who find substantive support for the role of descriptive representation are correct (e.g., Grose 2011; Mansbridge 1999; Tate 2003), African American and Latino legislators will be more likely to sponsor explicitly racial bills (openness to immigration bills), and more likely than white legislators to sponsor implicitly racial bills (Iraq withdrawal).

\section{Hypothesis 6}

If representation is really just about party and ideology (e.g., Lublin 1999; Lublin and Voss 2003), legislators who are Democrats should be more likely to sponsor explicitly (openness to immigration bills) and implicitly racial bills (Iraq withdrawal) than legislators who are Republicans. 


\section{Hypotheses 7 and 8}

If representation is based on responding to who lives in one's district (e.g. Mayhew 1974), those with larger mean African American and Latino populations in their districts, and those with lower mean median incomes in their districts, should be more likely to sponsor explicitly and implicitly racial bills.

\section{$\underline{\text { RESULTS }}$}

\section{Voting Behavior}

Tables 1 and 2 display the results of logistic regressions for the American Taxpayer Relief Act Vote (Table 1) and the TARP vote (Table 2). The entries are log odds. Hypotheses 1 and 2 predicted that Democrats and liberals respond better to lowincome group opinion. As seen in Table 1, even after controlling for legislator race and district characteristics, it is clear that party and ideology are dominant explanations in the model for legislator vote. Democrats were significantly less likely to vote "yes" on the American Taxpayer Relief Act. In Model 3, for example, when party=Democrat/1, the log odds of voting "yes" (versus "no") correspond to a nearly 100 percent decrease in the likelihood of voting yes when an legislator is a Democrat. Model 4 shows the similarly strong impact for ideology, regardless of dimension: more conservative representatives are far more likely (99 percent more likely) to vote "yes" on the American Taxpayer Relief Act.

This finding regarding the relevance of party and ideology holds for the Troubled Asset Relief Program vote. Again, regardless of legislator race or district characteristics, the magnitude of the relationship is strong. In Model 3, when party=Democrat/1, the log 
odds of voting "yes" on TARP increase by 5.83. Correspondingly, the relationship with ideology is negative: as ideology becomes more conservative, the likelihood of voting "yes" on TARP drops to nearly 0 , regardless of dimension.

Hypothesis 3 predicted that African American and Latino legislators would be more responsive to low-income group opinion. In the American Taxpayer Relief Act vote, as shown in Model 2 and Model 4 in Table 1, legislator race is not significant after controlling for party or ideology, nor is the relationship in the expected direction. The same is true for the Troubled Asset Relief Program Vote, as shown in Table 2. Below, I discuss some possible reasons for this.

Hypothesis 4 predicted that legislators with more African Americans or more Latinos in their districts, and more low-income African Americans and more low-income Latinos in their districts, would behave differently than other legislators. Tacit in this prediction is the belief that effective substantive representation will not be based on legislator race, or at least not just on legislator race, but district composition. Legislators with larger African American populations, or larger low-income African American populations in their districts, showed no significant signs of being less likely to vote "yes" on the American Taxpayer Relief Act, after controlling for party. In the ideology model, the only relevant district variable is white median income (as it increases, likelihood of voting yes on a tax cut increases, which is not surprising). On this vote, it looks like party and ideology carried the day. 
Table 1: American Taxpayer Relief Act Vote

\begin{tabular}{|c|c|c|c|c|}
\hline Variable & Model 1 & Model 2 & Model 3 & Model 4 \\
\hline Party $($ Democrat=1) & $\begin{array}{c}-7.65 * * * \\
(1.03)\end{array}$ & $\begin{array}{l}-7.51 * * * \\
(1.03)\end{array}$ & $\begin{array}{c}-7.77 * * * \\
(1.09)\end{array}$ & ------- \\
\hline \multicolumn{5}{|l|}{ Ideology } \\
\hline DWNoml & & & & $\begin{array}{l}12.43 * * * \\
(2.15)\end{array}$ \\
\hline DWNom2 & & & & $\begin{array}{c}6.84 * * * \\
(1.50)\end{array}$ \\
\hline \multicolumn{2}{|l|}{ MC Race } & & & \\
\hline American & ------- & $\begin{array}{l}-1.51 \\
(1.01)\end{array}$ & $\begin{array}{l}-1.35 \\
(1.12)\end{array}$ & $\begin{array}{l}1.53 \\
(1.66)\end{array}$ \\
\hline \multicolumn{5}{|l|}{$\begin{array}{l}\text { District } \\
\text { Characteristics }\end{array}$} \\
\hline AA Population & -------- & -------- & $\begin{array}{l}-0.19 \\
(0.24)\end{array}$ & $\begin{array}{l}-0.34 \\
(0.41)\end{array}$ \\
\hline $\begin{array}{l}\text { AA Median } \\
\text { Income }\end{array}$ & & -------- & $\begin{array}{l}-0.015 \\
(0.03)\end{array}$ & $\begin{array}{l}0.01 \\
(0.04)\end{array}$ \\
\hline $\begin{array}{l}\text { White Median } \\
\text { Income }\end{array}$ & --- & & $\begin{array}{l}-0.04 \\
(0.02)\end{array}$ & $\begin{array}{l}0.06^{*} \\
(0.03)\end{array}$ \\
\hline Constant & $\begin{array}{l}5.46 * * * \\
(1.00)\end{array}$ & $\begin{array}{l}5.50 * * * \\
(1.00)\end{array}$ & $\begin{array}{c}11.07 * * \\
(3.20)\end{array}$ & $\begin{array}{l}-2.60 \\
(4.19)\end{array}$ \\
\hline
\end{tabular}

Note: $\mathrm{N}=426$. The dependent variables are legislator votes, where $1=$ yes and $0=$ no. Entries are log odds; standard errors are in parentheses. Population variables are log-transformed; income is scaled to thousands. There were 41 African Americans in the $112^{\text {th }}$ Congress.

$* * *=\mathrm{p}<0.001 * *=\mathrm{p}<0.01 *=\mathrm{p}<0.05$ 
Table 2: TARP Vote

\begin{tabular}{|c|c|c|c|c|}
\hline & Model 1 & Model 2 & Model 3 & Model 4 \\
\hline Party $($ Democrat $=1)$ & $\begin{array}{c}5.42 * * * \\
(0.61)\end{array}$ & $\begin{array}{c}5.39 * * * \\
(0.61)\end{array}$ & $\begin{array}{c}5.83^{* * * *} \\
(0.65)\end{array}$ & ------- \\
\hline \multicolumn{5}{|l|}{ Ideology } \\
\hline DWNoml & & & & $\begin{array}{c}-9.04 * * * * \\
(1.08)\end{array}$ \\
\hline DWNom 2 & & & & $\begin{array}{c}-4.24 * * * \\
(0.82)\end{array}$ \\
\hline \multicolumn{5}{|l|}{ MC RACE } \\
\hline Latino & & & & \\
\hline & ----- & $\begin{array}{l}1.24 \\
(0.98)\end{array}$ & $\begin{array}{l}2.70^{*} \\
(1.09)\end{array}$ & $\begin{array}{c}1.49 \\
(1.22)\end{array}$ \\
\hline \multicolumn{5}{|l|}{$\begin{array}{l}\text { District } \\
\text { Characteristics }\end{array}$} \\
\hline Latino Population & ------ & ------ & $\begin{array}{l}-0.85 * * * \\
(0.22)\end{array}$ & $\begin{array}{l}-0.55^{*} \\
(0.26)\end{array}$ \\
\hline $\begin{array}{l}\text { Latino Median } \\
\text { Income }\end{array}$ & --------- & ------ & $\begin{array}{l}-0.013 \\
(0.02)\end{array}$ & $\begin{array}{l}0.00 \\
(0.02)\end{array}$ \\
\hline $\begin{array}{l}\text { White Median } \\
\text { Income }\end{array}$ & ---.. & ---- & $\begin{array}{l}0.05^{* * *} \\
(0.01)\end{array}$ & $\begin{array}{l}0.02 \\
(0.02)\end{array}$ \\
\hline Constant & $\begin{array}{c}-1.13^{* * * *} \\
(0.168)\end{array}$ & $\begin{array}{c}-1.16^{* * * *} \\
(0.171)\end{array}$ & $\begin{array}{l}4.70^{*} \\
(2.13)\end{array}$ & $\begin{array}{l}8.99 * * * \\
(2.56)\end{array}$ \\
\hline
\end{tabular}

Note: $\mathrm{N}=415$. The dependent variables are legislator votes, where $1=$ yes and $0=$ no. Entries are log odds; standard errors are in parentheses. Population variables are log-transformed; income is scaled to thousands. There were 25 Latinos in the $110^{\text {th }}$ Congress. 
The findings for the Troubled Asset Relief Program vote are a bit different. While party remains a very strong predictor, legislator race (Latino compared to other legislators) becomes significant, as do district Latino population and white median income. The scatterplot in Figure 1 shows that Latinos are certainly not the only ones voting for TARP, but they have a higher likelihood of doing so than many non-Latinos. However, the Latino population variable and the white median income variable do not behave as expected: larger Latino populations reduce the likelihood of voting yes, while white median income has a positive relationship with legislator vote on TARP (strange since high-income whites were against TARP). What is happening here?

\section{Figure 1}

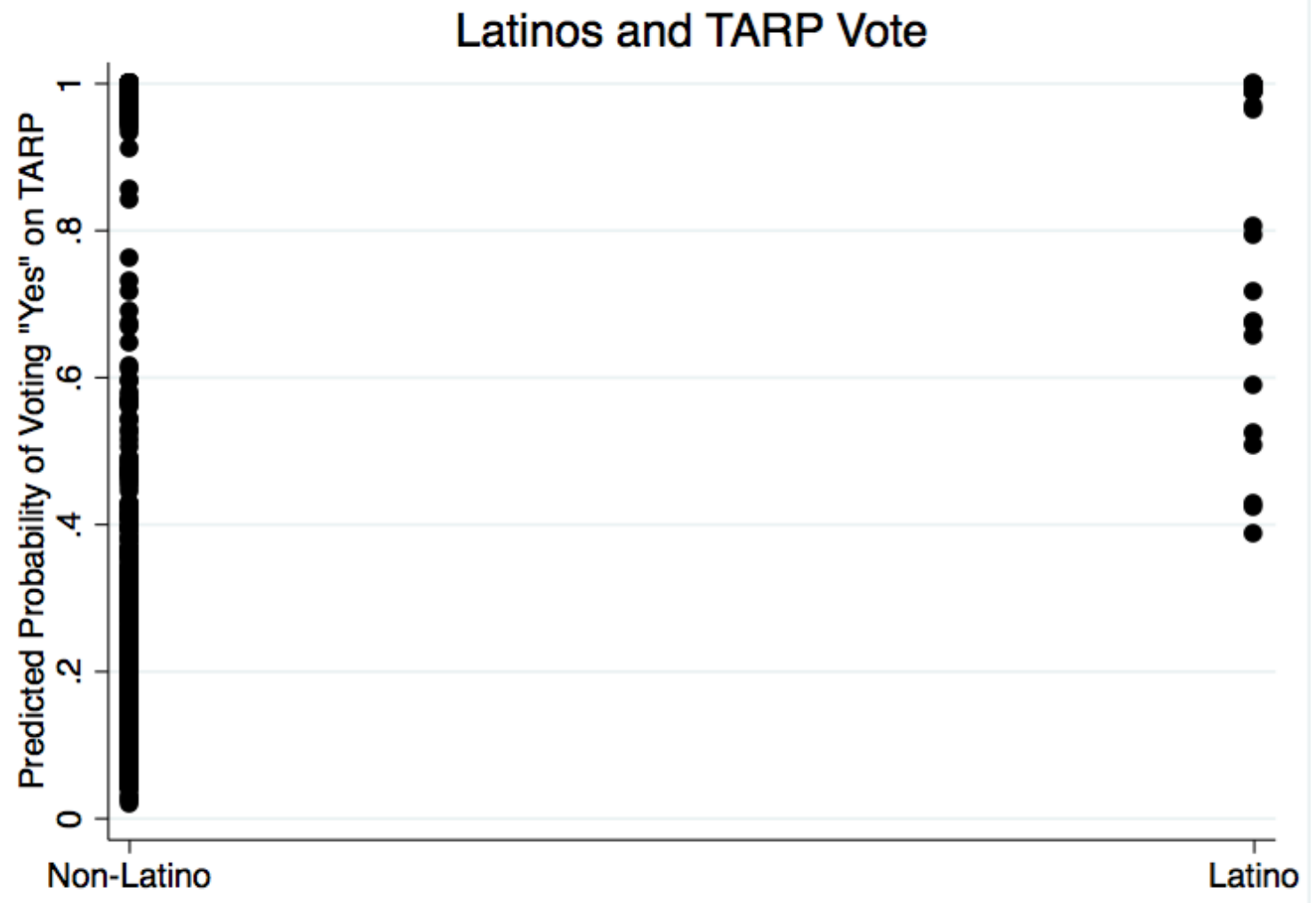


I believe Latino Republicans explain these perplexing findings. Based on Model 3, I simulated 1,000 votes for TARP. ${ }^{9}$ Holding Latino median income and white median income at their means, and holding Latino population first at its mean and then its maximum, while varying party and legislator race, provides some interesting illustrations. For TARP, where low-income Latino opinion is unique, one might expect Democrats who are Latino to be especially responsive, relative other Democrats. In these simulations, while Latinos are slightly more likely than other Democratic legislators to vote "yes" on TARP, the difference based on legislator race among Democrats is miniscule. Democrats are simply very likely to vote "yes," regardless of race (see Figure 2). As Figure 3 shows, however, Latino Republicans behave very differently from other Republicans in these simulations. In simulations holding Latino district population at its mean, Republicans who are Latino have a 74 percent probability of voting "yes" on TARP, while other Republicans have only a 20 percent probability of voting "yes" on TARP.

What about district characteristics? After all, the "Latino legislator" and "Latino population" variables are highly correlated, as majority-minority districts tend to be required to elect nonwhite legislators (Bowler and Segura 2011). Again, based on simulations, Figures 4 and 5 show the differing impact of large Latino populations among Latino Democrats and Republicans. Latino Democrats and other Democrats with large Latino populations do not behave substantially differently (Figure 4). Latino Republicans and other Republicans with large Latino populations do, however (Figure 5). Having a large Latino population far from ensured a Latino Republican vote of "yes" on TARP;

\footnotetext{
${ }^{9}$ Using Stata's Clarify program.
} 
only 36 percent of Latino Republicans with large Latino populations in these simulations did so. However, Latino Republicans were far more responsive to district characteristics than were other Republican legislators with large Latino populations, who have a less than five percent likelihood of voting "yes." The different impact of legislator race and district characteristics among Republicans may explain the perplexing findings seen in Table 2, Model 3.

Figure 2 Simulated Votes on TARP; Democrats

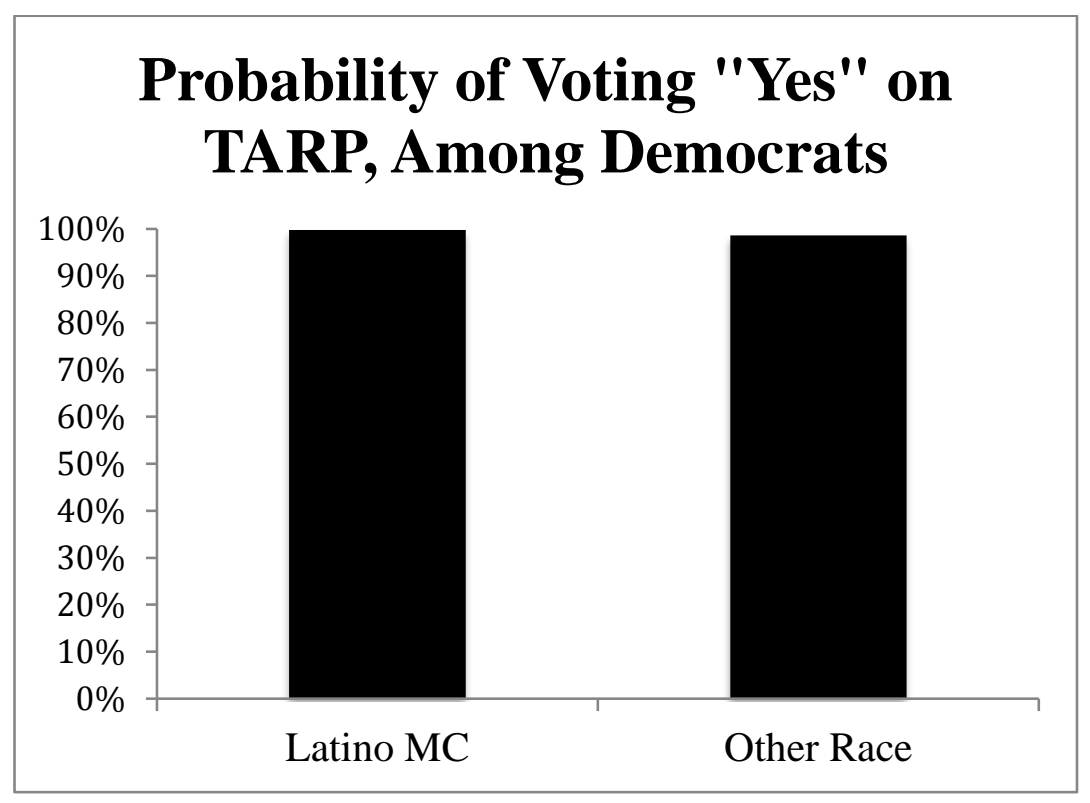


Figure 3 Simulated Votes on TARP; Republicans

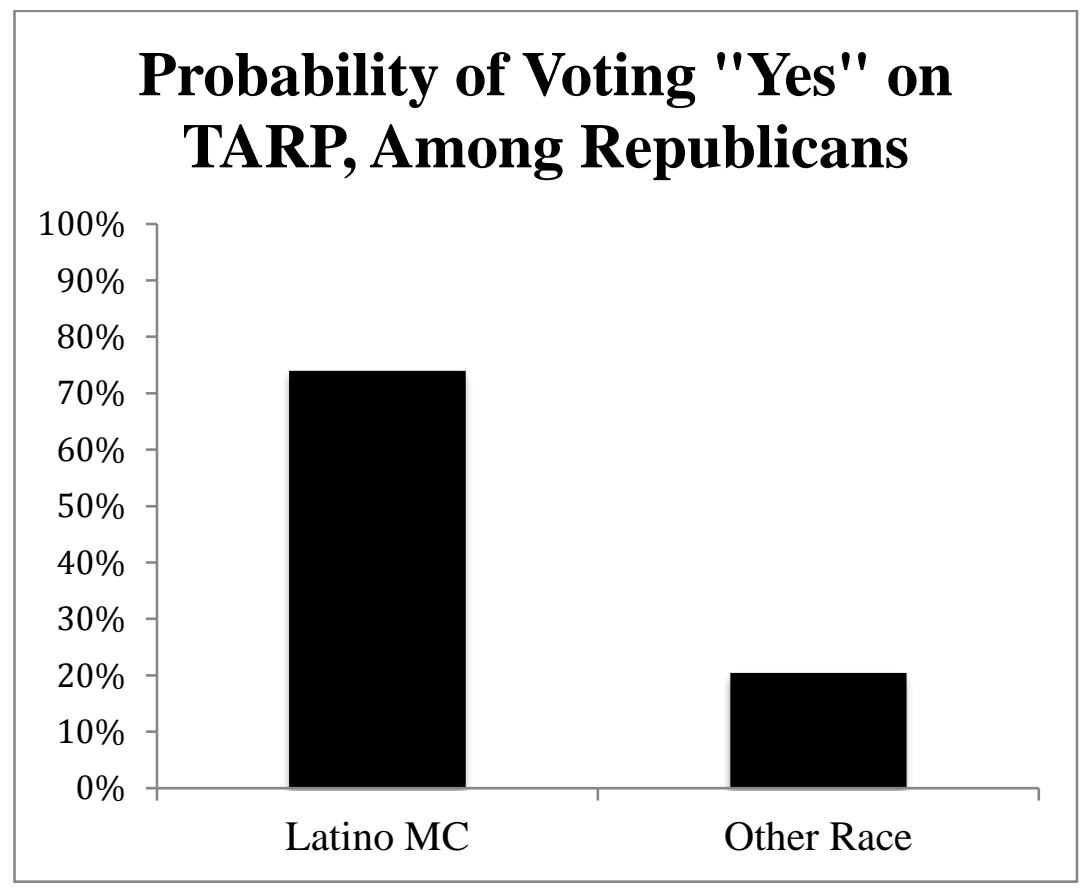

Figure 4 Simulated Votes on TARP; Democrats with Large Latino Populations

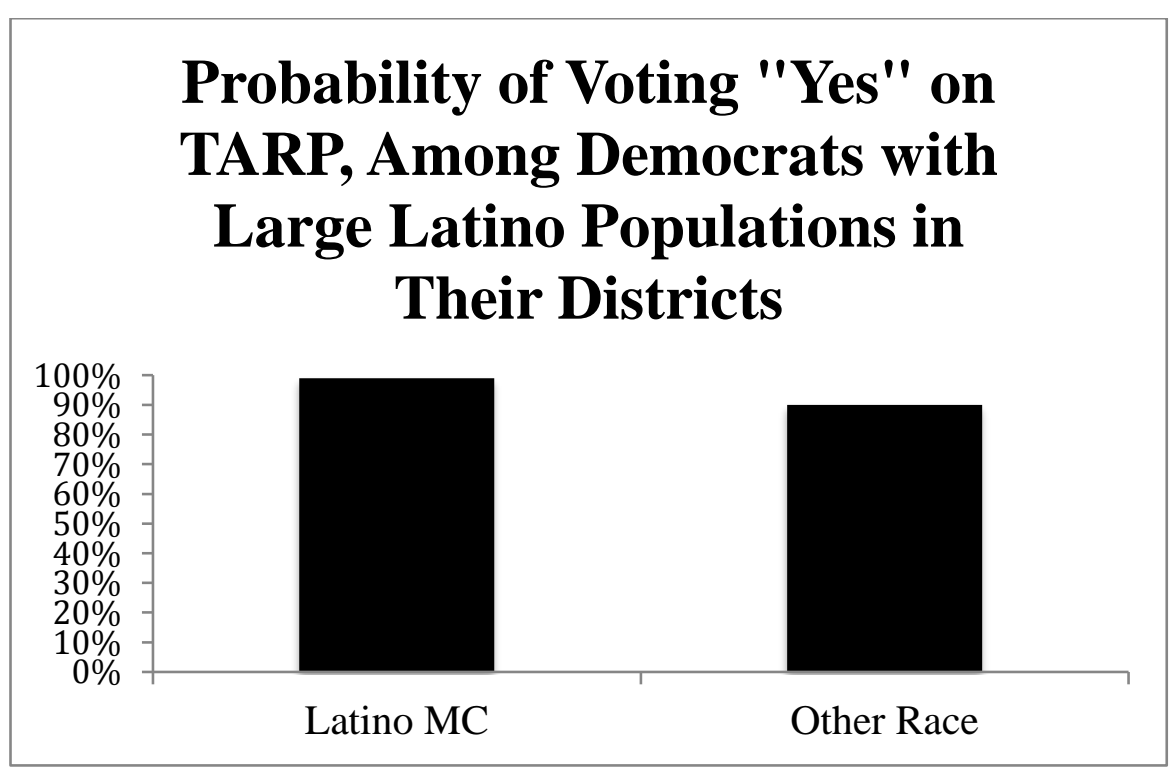




\section{Figure 5 Simulated Votes on TARP; Republicans with Large Latino Populations}

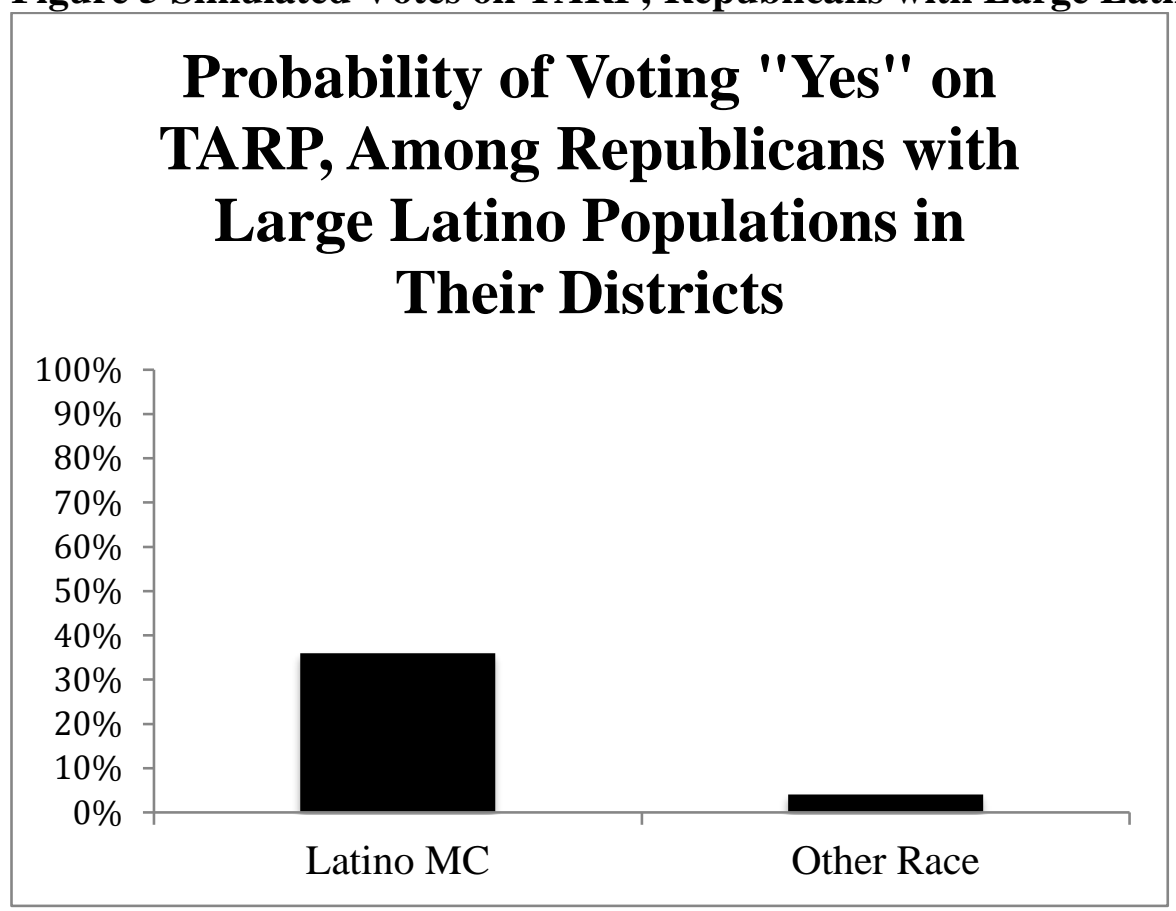

The overwhelming likelihood of voting yes among Democrats, and the fact that

Latino legislators are more likely to be Democrats ( 80 percent of Latinos in the $110^{\text {th }}$ Congress were Democrats), may explain why legislator race is not significant in Table 2, Model 2, when only those two variables are included. In Model 3, when district characteristics are included, the differential behavior among Republicans matters again. Party remains significant because Democrats are far more likely to vote "yes" on TARP, regardless of race or district characteristics. The influence of legislator race becomes clearer, though, because majority-Latino districts are likely to have a Latino legislator, and Latino Republicans are much more likely than other Republicans to vote "yes" when they have large Latino populations. Finally, the Latino population variable has a negative impact upon legislator vote, because after controlling for legislator race and party, the remaining high-volume Latino districts have Republican, non-Latino legislators, who are very unlikely to vote "yes" on TARP. 
These illustrations do not explain the direction of the relationship between white median income and legislator vote. As Figure 6 shows, the probability of voting "yes" on TARP is less then 0.5 at the lowest income levels, and increases to just under 1 at the highest income levels. We know from Gilens (2012) that high-income opinions receive a lot of responsiveness; however, high-income whites in the CCES were against TARP. In any case, it is clear that the low-income Black and Latino populations did not drive legislator behavior, which aligns with my theory.

In Model 4, it is evident that, unlike party, including both dimensions of Poole and Rosenthal's ideology scores wipes out the role of Latino legislator for TARP vote. Both the first dimension ideology score and the second dimension ideology score have strong relationships with vote choice ${ }^{10}$ : more conservative legislators are much less likely to vote yes. Latino population continues its negative relationship with a TARP "yes" vote, and district Latino median income remains insignificant. These findings might suggest it is ideology, not legislator race, determining vote choice, and that, rather, Latino legislators are just less conservative than other Republicans. If this is true, this is still an important finding for legislator race if Latino legislators are consistently more liberal. Simulations of the TARP vote again suggest that legislator race matters. Among the most conservative Republicans in the simulation (DW-NOM 1 and 2=1), the difference is not very stark. The likelihood of a "yes" vote among very conservative Latino Republicans is 3 percent, while the likelihood of a "yes" vote among very conservative white Republicans is 0.3 percent. Among mid-range conservatives, however (DW-NOM 1 and $2=0.5$ ), the vote choice simulation shows a bigger difference for Latino

\footnotetext{
${ }^{10}$ Log likelihoods and AIC/BIC tests confirm that the model performs best when both dimensions are included.
} 
conservatives versus white conservatives (see Figure 7). While Latino conservatives are more likely to vote "no" than "yes," they're far more likely to vote "yes" than other conservatives, to the tune of 40 percent versus 13 percent.

Figure 6: White Median Income and TARP Vote

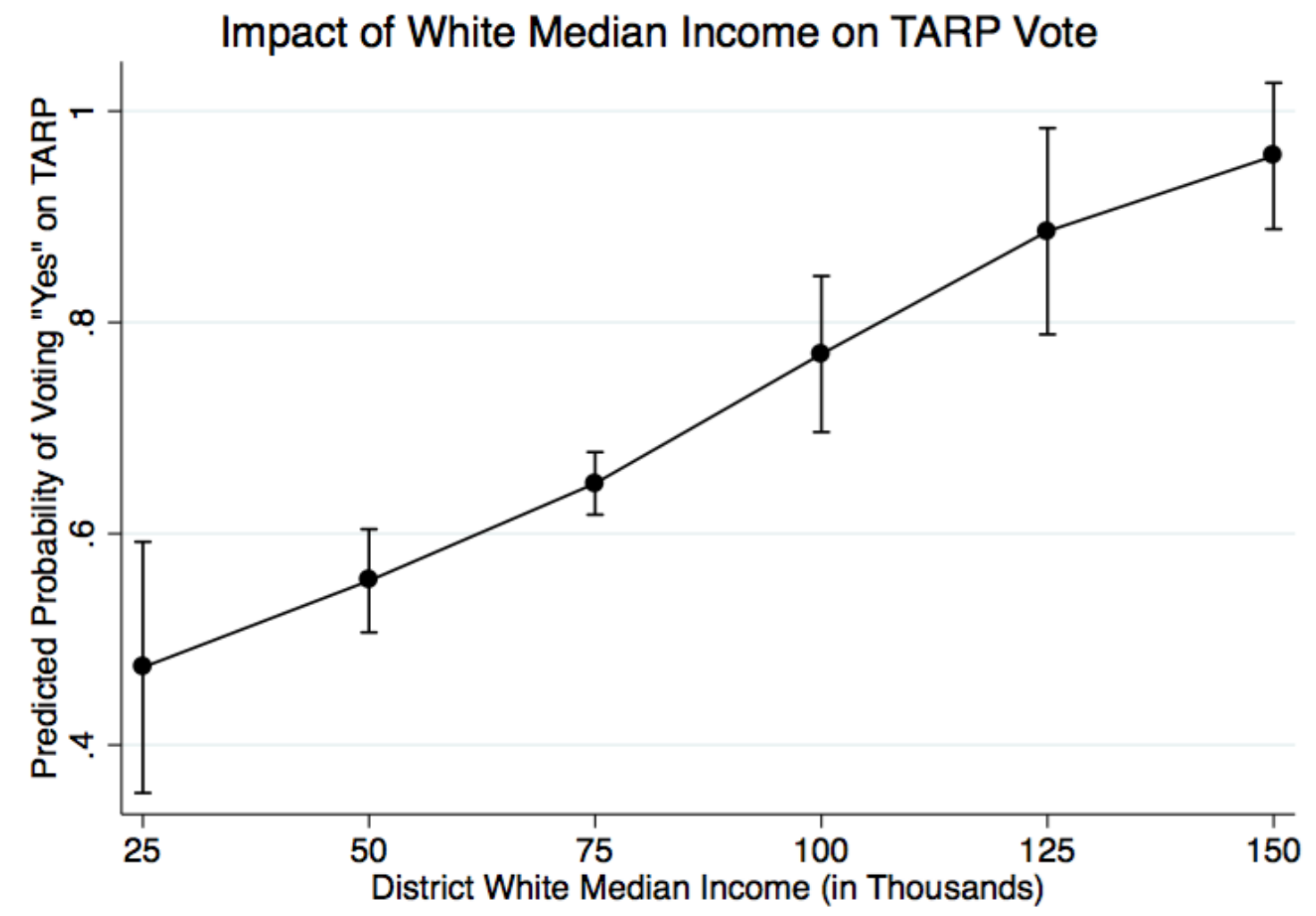

Figures 8 and 9 confirm that it is largely DW-NOM 1 scores driving this difference. When DW-NOM 2 scores are held at 0 in the simulation, and DW-NOM 1 scores held at 0.5 , the probability of voting yes on TARP among Latino mid-range conservatives is 78 percent (Figure 8). When DW-NOM 1 scores are held at 0 , and DWNOM 2 scores held at 0.5 , there is very little difference between Latino legislators and other legislators (Figure 9). Figures 10 and 11 confirm that, as with party, in the vote simulation, whether one examines both dimensions of ideology (Figure 10) or DW-NOM 1 only (Figure 11), conservative Latino legislators with large Latino populations behave 
differently than other Latino legislators. While conservative Latino legislators will probably not vote "yes" on TARP, they are more likely than other conservative legislators to vote "yes" in the simulation.

This finding is not strong enough to show up in Model 4, however. The likely reason is that there were not many Republican or conservative Latinos in the $110^{\text {th }}$ Congress, and the simulation strengthens their influence by essentially running more "votes." There were 25 Latinos in the $110^{\text {th }}$ Congress, and 84 percent of them were Democrats. This means there were only four Latino Republicans in the $110^{\text {th }}$ Congress. However, in $111^{\text {th }}$ Congress there were five Latino Republicans, and in the $112^{\text {th }}$ Congress, there were eight Latino Republicans. Their different approach will be felt more if this number continues to grow.

Further, there were just nine white Republicans with district Latino populations at least one standard deviation above the mean (greater than 240,000 Latinos; districts located in California, New Mexico, and Texas), and 22 white Republicans with district Latino populations at least 1 standard deviation above the mean. These smaller numbers make comparisons between Latino-populated districts with Republican or conservative Latino legislators versus Republican or conservative white legislators, who appear to behave very differently, more reasonable and meaningful, especially as these numbers seem to be growing as well. 
Figure 7 Simulated Probability of Voting "Yes" on TARP, Among Conservatives (ideology $=0.5$ )

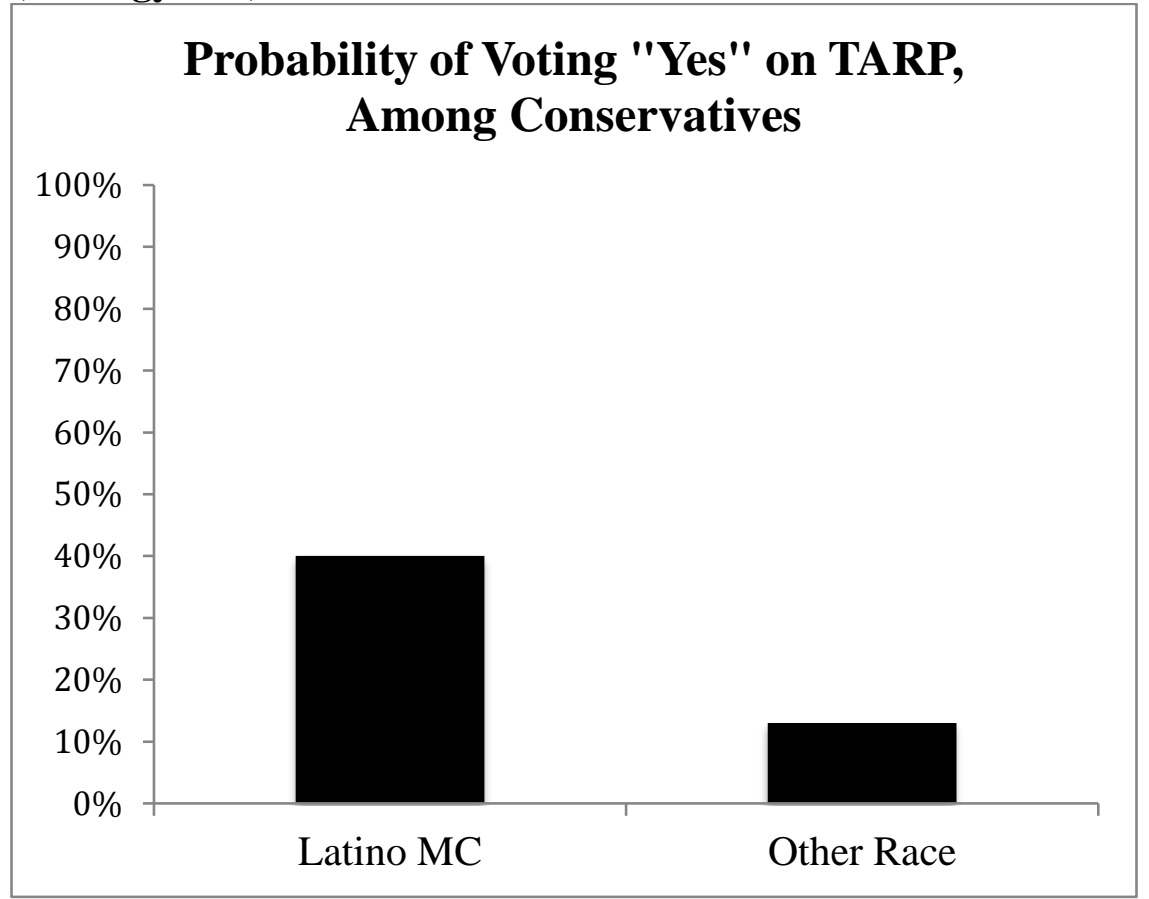

Figure 8 Simulated Probability of Voting "Yes" on TARP, Among Conservatives (DW-NOM 1=0.5)

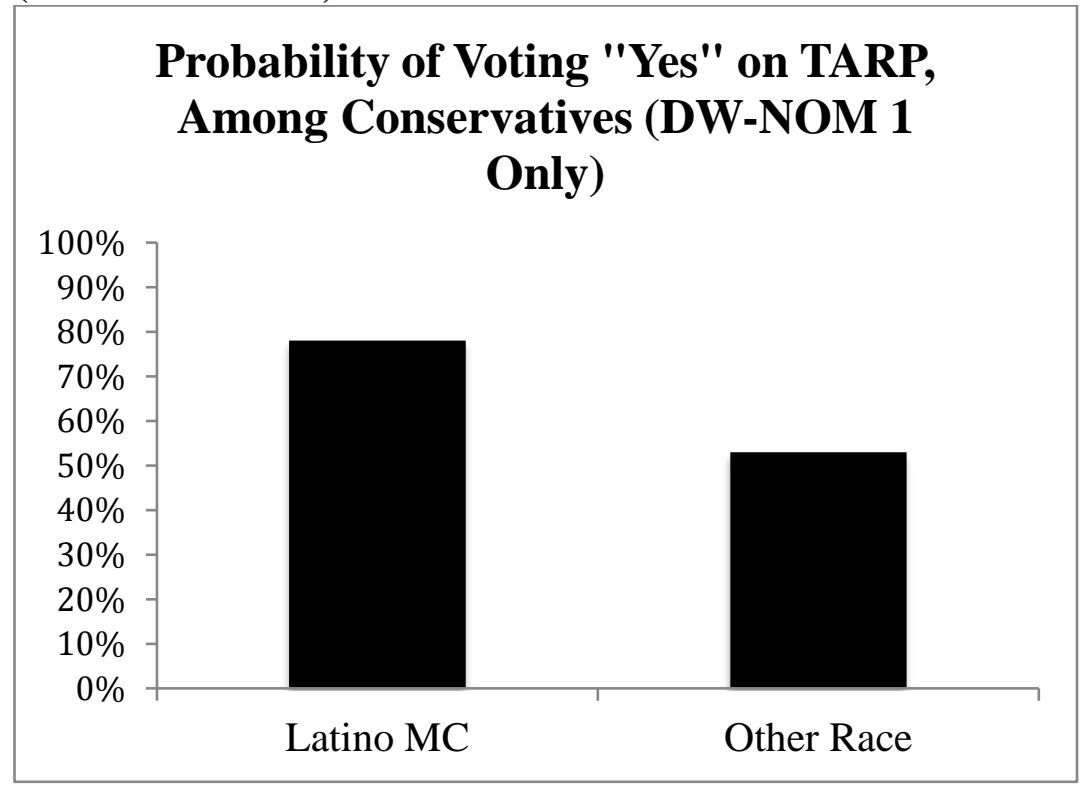


Figure 9 Simulated Probability of Voting "Yes" on TARP, Among Conservatives (DW-NOM 2=0.5)

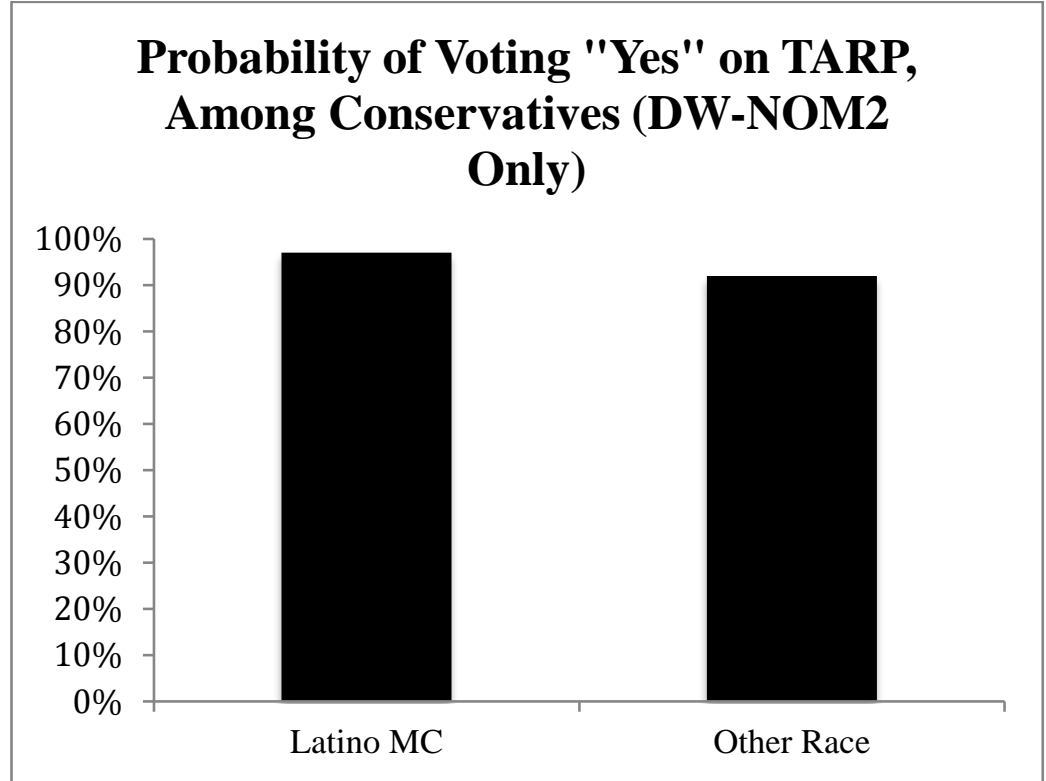

Figure 10 Simulated Probability of Voting Yes on TARP, Among Conservatives (ideology $=0.5$ )

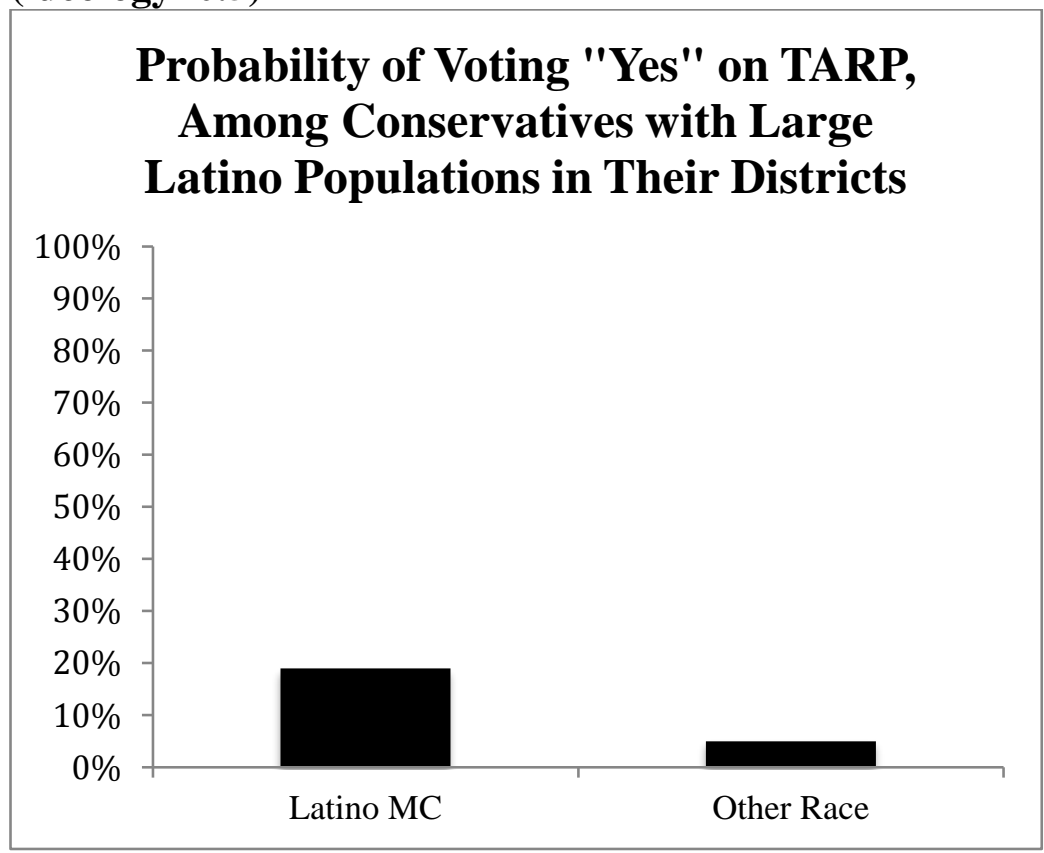


Figure 11 Simulated Probability of Voting Yes on TARP, Among Conservatives (DW-NOM 1=0.5)

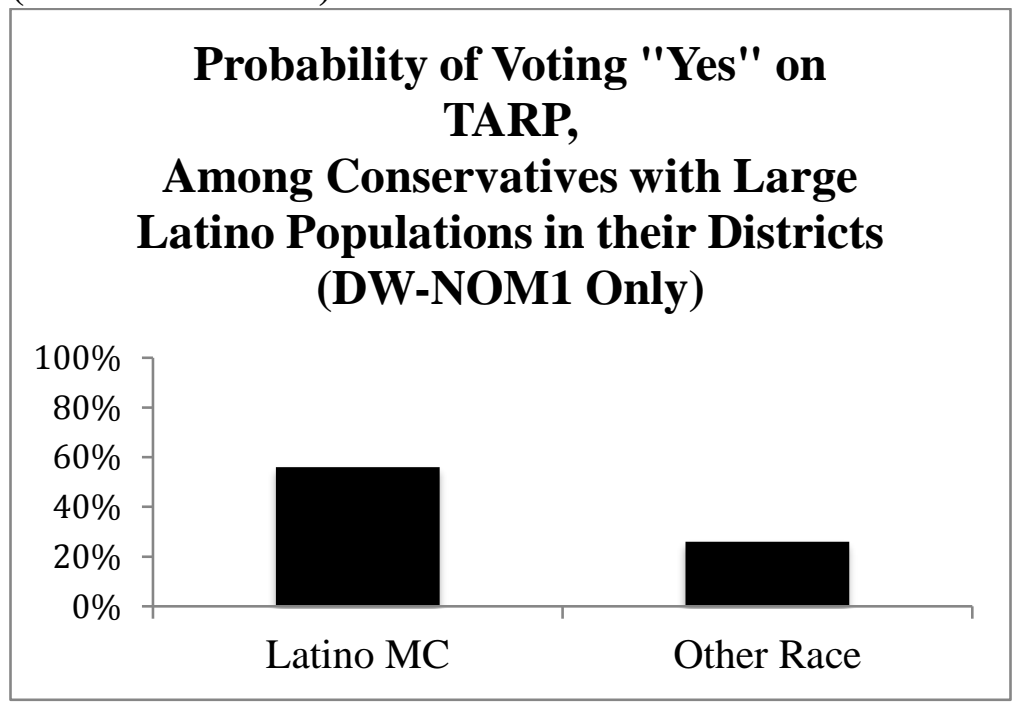

Therefore, I view the differential behavior among conservative Latinos in the simulations demonstrate to be interesting and potentially even more meaningful in the future. However, it is clear that the strongest relationships highlighted in the two vote choice models are not legislator race, or even district characteristics. My theory of narrow representation predicts that on implicitly racial issues, Blacks and Latinos, especially low-income Blacks and Latinos, are not heard as well as whites. Importantly, I do not argue the opinions of low-income individuals ordinarily determine the behaviors of members of Congress. We know political activity is decreased among low-income individuals (e.g., Bowler and Segura 2011), and that representatives pay attention to their "re-election constituency" the most (e.g., Fenno 1978). Still, even though Democrats sided with low-income Blacks and Latinos on these two issues - despite all other groups being against that position on these issues, including high-income Blacks and Latinos we might expect to be more politically active — district demography and median income did not factor in as having a significant relationship with vote. It is not clear that "re-election 
constituencies" (Fenno 1978), or at least high-income voters, drove Democrats' behavior, either.

\section{Sponsorships}

Hypotheses 5, 6, 7, and 8 dealt with legislator sponsorship behavior based on race and party. Two-way tests of proportion compare the behavior of Democratic and Republican legislators, and white, African American, and Latino legislators. As shown in Table 3, 18 of 265 Democrats (7 percent of Democrats), and 3 of 300 Republicans (1 percent of Republicans) sponsored Open Immigration legislation. This is a significant difference in sponsorship behavior by party $(\mathrm{p}=0.0002)$. Republicans sponsored significantly more Closed to Immigration bills ( $\mathrm{p}=0.0031)$ : 27 of 300 Republicans (9 percent) compared to 8 of 265 Democrats (3 percent). Finally, Democrats were also more active on the selected implicitly racial issue, Iraq withdrawal ( $p=0.000) .32$ of 265 Democrats (12 percent) and 7 of 300 Republicans (2 percent) sponsored Iraq withdrawal legislation (some of these sponsored multiple bills; see Appendix F). This conforms to the expectations in Hypothesis 6: Democrats are more active than Republicans on both, Iraq withdrawal sponsorships (implicit) and openness to immigration (explicit).

Table 3: Comparing Parties on Explicitly and Implicitly Racial Issues

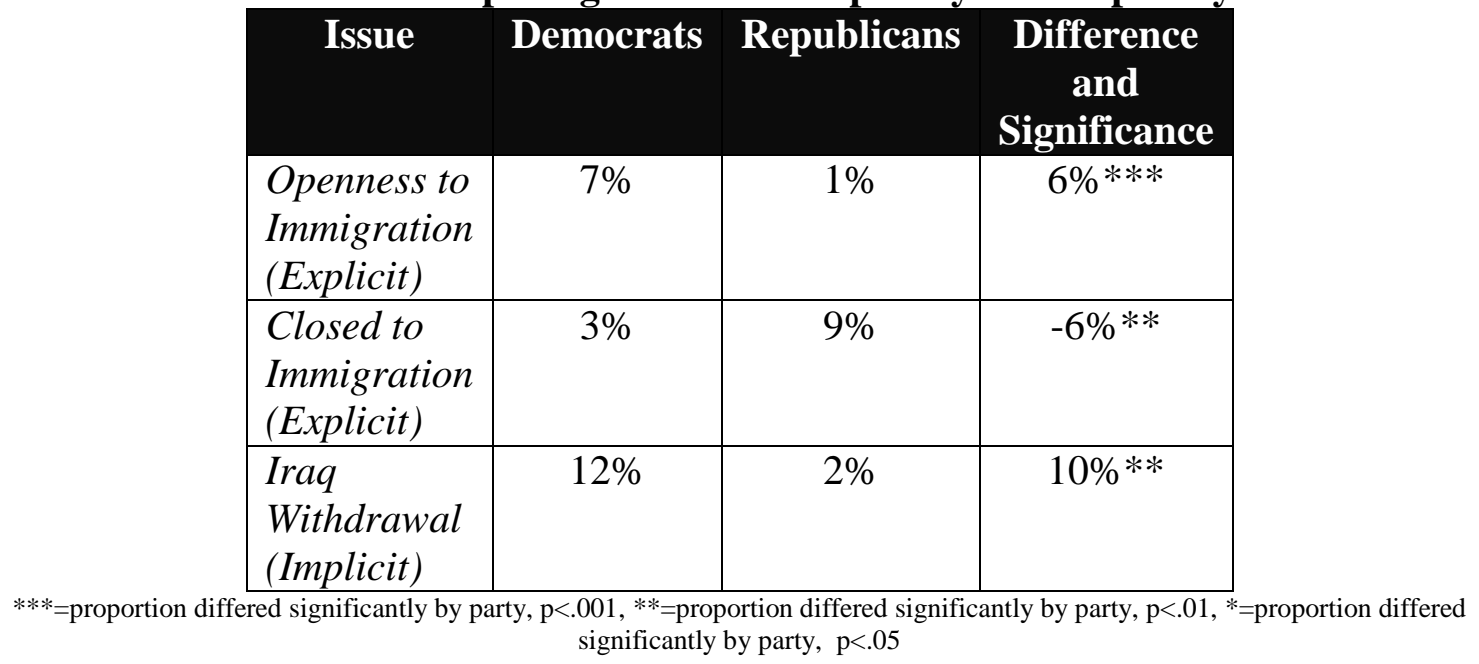


Hypothesis 5 predicts that African American and Latino legislators will be more active than white legislators on explicitly racial and implicitly racial bills. As Table 4 shows, however, it appears the theory of narrow representation largely holds up here. There is no significant difference in the proportion of white, Latino, and African American legislators sponsoring Iraq withdrawal bills $(p=0.1404$ for white-Latino, $\mathrm{p}=0.7915$ for white-African American, and $\mathrm{p}=0.1179$ for African American-Latino).

Despite the liberal opinions of African Americans on immigration, African American legislators are no more likely than white legislators to sponsor "openness to immigration" bills $(\mathrm{p}=0.6860)$. However, Latino legislators are much more active in sponsoring openness to immigration bills than are either white or African American legislators. 7 of 29 Latino legislators sponsored "openness to immigration" legislation, compared to 13 of 477 whites $(p=0.000)$ and 1 of 51 African Americans $(p=0.0016)$. On "closed to immigration" legislation, there is no significant difference in sponsorship behavior based on race $(p=0.1404$ for white-Latino, $p=0.1691$ for white-African American, and $p=0.4434$ for African American-Latino).

Table 4: Comparing Legislators by Race

\begin{tabular}{lcccccc}
\multicolumn{1}{c}{ Issue } & Whites & Latinos & $\begin{array}{c}\text { African } \\
\text { Americans }\end{array}$ & $\begin{array}{c}\text { Difference, } \\
\text { Whites vs. } \\
\text { Latinos }\end{array}$ & $\begin{array}{c}\text { Difference, } \\
\text { Whites vs. } \\
\text { African }\end{array} \begin{array}{c}\text { Difference, } \\
\text { Latinos vs. } \\
\text { African }\end{array}$ \\
$\begin{array}{l}\text { Apenness to } \\
\text { Immigration } \\
\text { (Explicit) }\end{array}$ & $3 \%$ & $24 \%$ & $2 \%$ & $-21 \% * * *$ & $1 \%$ & $22 \% * *$ \\
Americans
\end{tabular}


To extricate the role of party and race, I also compared just Democrats of all races, white Democrats to white Republicans, and Latino Democrats to Latino Republicans. Tables 5 and 6 display the results. Latino Democrats are more likely to sponsor open immigration legislation than white Democrats or African American Democrats. 6 of 20 Latino Democrats (30\%) sponsored such legislation, compared to 11 of 190 white Democrats $(6 \%, \mathrm{p}=0.0000)$, and 1 of 49 African American Democrats $(2 \%$, $\mathrm{p}=0.0005)$. White Democrats and African American Democrats show no significant difference in their sponsorship behavior here $(\mathrm{p}=0.2600)$. Interestingly, though white Democrats and white Republicans display very different sponsorship likelihoods on this issue ( $\mathrm{p}=0.0017)$, Latino Democrats and Republicans do not $(\mathrm{p}=0.2684)$. This conforms to the differential behavior of Latinos on an explicitly racial issue; for whites, party makes more of a difference.

White, Latino, and African American Democrats display no significant differences in their sponsorship behavior on closed to immigration bills. Democrats simply are not very active in this issue area. Neither Latino Democrats nor Latino Republicans sponsored closed immigration legislation, but there is a significant difference for white Democrats and white Republicans. 27 of 287 white Republicans sponsored closed to immigration legislation, while only 7 of 190 Democrats did ( $\mathrm{p}=0.0363)$. White Republicans, rather than Democrats of any race, are clearly more likely to be doing the work on this issue, and, as with the earlier analysis, Latino Republicans differ from other Republicans in their behavior here.

For Iraq withdrawal sponsorships, there is a strong role for party over race. There are no significant racial differences in sponsorship behavior among Democrats, but white 
Republicans and Democrats differ a great deal: 28 of 190 white Democrats sponsored such bills, while only 7 of 287 white Republicans did ( $\mathrm{p}=0.000)$. For this implicitly racial issue, party matters more than race.

Democrats are more active on implicitly and explicitly racial issues, but Latino Democrats are particularly strong on the "openness" dimension of an explicitly racial issue, immigration. Clearly, then, descriptive representation has some relevance for substantive representation on the explicitly racial issue examined here, but not for the implicitly racial issue, Iraq withdrawal. Party rather than race plays the dominant role on implicitly racial issues, despite much stronger Black and Latino opinion on Iraq withdrawal. Narrow representation also shows itself in African American legislators' lack of activity on this issue; despite African Americans' comparatively liberal take on immigration, African American legislators are not significantly more active on this issue than white legislators.

Table 5: Comparing Legislators at the Intersection of Race and Party: Democrats of Different Races

\begin{tabular}{|c|c|c|c|c|c|c|}
\hline Issue & $\begin{array}{c}\text { White } \\
\text { Democrats }\end{array}$ & $\begin{array}{c}\text { Latino } \\
\text { Democrats }\end{array}$ & $\begin{array}{c}\text { African } \\
\text { American } \\
\text { Democrats }\end{array}$ & $\begin{array}{c}\text { Difference, } \\
\text { White vs. } \\
\text { Latino } \\
\text { Dems }\end{array}$ & $\begin{array}{l}\text { Difference, } \\
\text { White vs. } \\
\text { African } \\
\text { American } \\
\text { Dems }\end{array}$ & $\begin{array}{l}\text { Difference, } \\
\text { African } \\
\text { American } \\
\text { vs. Latino } \\
\text { Dems }\end{array}$ \\
\hline $\begin{array}{l}\text { Openness to } \\
\text { Immigration } \\
\text { (Explicit) }\end{array}$ & $6 \%$ & $30 \%$ & $2 \%$ & $-24 \% * *$ & $4 \%$ & $28 \% * *$ \\
\hline $\begin{array}{l}\text { Closed to } \\
\text { Immigration } \\
\text { (Explicit) }\end{array}$ & $4 \%$ & $0 \%$ & $2 \%$ & $4 \%$ & $2 \%$ & $-2 \%$ \\
\hline $\begin{array}{l}\text { Iraq } \\
\text { Withdrawal } \\
\text { (Implicit) }\end{array}$ & $15 \%$ & $0 \%$ & $8 \%$ & $15 \%$ & $7 \%$ & $-8 \%$ \\
\hline
\end{tabular}


Table 6: Comparing Legislators at the Intersection of Race and Party:

Democrats and Republicans

\begin{tabular}{|c|c|c|c|c|c|c|}
\hline Issue & $\begin{array}{c}\text { White } \\
\text { Democrats }\end{array}$ & $\begin{array}{c}\text { White } \\
\text { Republicans }\end{array}$ & $\begin{array}{c}\text { Latino } \\
\text { Democrats }\end{array}$ & $\begin{array}{c}\text { Latino } \\
\text { Republicans }\end{array}$ & $\begin{array}{c}\text { Difference, } \\
\text { White } \\
\text { Democrats } \\
\text { vs. } \\
\text { Republicans }\end{array}$ & $\begin{array}{c}\text { Difference, } \\
\text { Latino } \\
\text { Democrats } \\
\text { vs. } \\
\text { Republicans }\end{array}$ \\
\hline $\begin{array}{l}\text { Openness to } \\
\text { Immigration } \\
\text { (Explicit) }\end{array}$ & $7 \%$ & $1 \%$ & $30 \%$ & $11 \%$ & $6 \% * *$ & $19 \%$ \\
\hline $\begin{array}{l}\text { Closed to } \\
\text { Immigration } \\
\text { (Explicit) }\end{array}$ & $4 \%$ & $9 \%$ & $0 \%$ & $0 \%$ & $-5 \% *$ & $0 \%$ \\
\hline $\begin{array}{l}\text { Iraq } \\
\text { Withdrawal } \\
\text { (Implicit) }\end{array}$ & $15 \%$ & $2 \%$ & $0 \%$ & $0 \%$ & $13 \% * * *$ & $0 \%$ \\
\hline
\end{tabular}

What about district characteristics? T-tests compare the mean district racial group populations and mean district median incomes for those legislators who did and did not sponsor open immigration bills, closed immigration bills, and Iraq withdrawal bills. Hypothesis 7 predicts that larger mean Black and Latino populations will be likely among those who sponsored openness to immigration bills. As Table 7 shows, those with larger mean Latino populations were more likely to sponsor open immigration legislation $(\mathrm{p}=0.000)$, and those with lower mean white populations were more likely to sponsor open immigration legislation $(\mathrm{p}=0.0001)$. There is no significant difference in mean African American population among those who did and did not sponsor openness to immigration legislation $(\mathrm{p}=0.6009)$. There was also no significant difference in mean African American $(\mathrm{p}=0.3137)$ or Latino population $(\mathrm{p}=0.7088)$ among those who did and did not sponsor closed to immigration legislation. However, the mean district white 
population was significantly higher among those who sponsored closed to immigration legislation ( $\mathrm{p}=0.0307$ ). For the implicitly racial issue, Iraq withdrawal sponsorship, there was no significant difference in mean district African American ( $\mathrm{p}=0.1933)$, Latino (0.2757) or white population size (0.6217) among those who did and did not sponsor such legislation. Appendix G displays which states had legislators who sponsored each type of legislation, and one can see that openness to immigration sponsorship behavior is more concentrated than sponsorships in the other two areas, particularly Iraq withdrawal, which fits with these findings. That is, this dimension of the explicitly racial issue is affected most by legislator race, and Latino legislators tend to be located in states with larger Latino populations.

The test of hypothesis 8 provides some surprises, though is not entirely surprising for the theory of narrow representation. Lower-income African Americans and Latinos were especially likely to support amnesty for illegal immigrants. Despite this, neither mean district African American median income $(\mathrm{p}=0.1992)$ nor Latino median income $(\mathrm{p}=0.5084)$ was significantly lower among those who sponsored openness to immigration legislation. However, there was a difference among those who did and did not sponsor closed to immigration legislation: those who did tended to be from districts with higher mean African American median incomes $(\mathrm{p}=0.0086)$ and Latino median incomes $(\mathrm{p}=0.03)$. The same issue arises for sponsorship on the implicitly racial issue, Iraq withdrawal. Those who sponsored such legislation were from districts with higher mean median incomes among whites $(\mathrm{p}=0.0302)$ and African Americans (0.0124), even though withdrawing from Iraq was more popular among low-income individuals. Narrow representation expects a lack of responsiveness to low-income interests on implicitly 
racial issues in particular. In keeping with the theory of narrow representation and with Gilens (2012), sponsorship activity on Iraq withdrawal did not appear to be influenced by low-income populations.

\section{DISCUSSION AND CONCLUSION}

For legislator vote on two implicitly racial issues, party and ideology largely carried the day. These analyses confirm that party and ideology were the dominant forces in determining vote choice on a substantively important issue to Blacks and Latinos. However, I show that this is also true for issues that are differently supported by Blacks and Latinos of different income levels. Democrats and liberals were far more likely than Republicans and conservatives to vote in the direction low-income groups

desired. Legislator race does not exhibit a significant role apart from party for Democrats and liberals, but for the small number of Latino Republicans voting on TARP, it did. Similarly, district characteristics did not determine Democrats' votes on TARP, but they did affect Latino Republicans differently than other Republicans.

Based on these findings, those who embrace the idea that party and ideology, not descriptive representation, determine substantive representation are partly correct when it comes to issues that elicit different responses among respondents at different income levels. However, this may be too blunt an assessment: Latino Republicans do seem to be more liberal than other Republicans on these two racialized issues. Therefore, the impact of legislator race and district may be more nuanced than an argument for simply electing Democrats conveys, and not entirely unimportant for implicitly racial 
Table 7: District Racial Population and Median Income and Bill Sponsorship

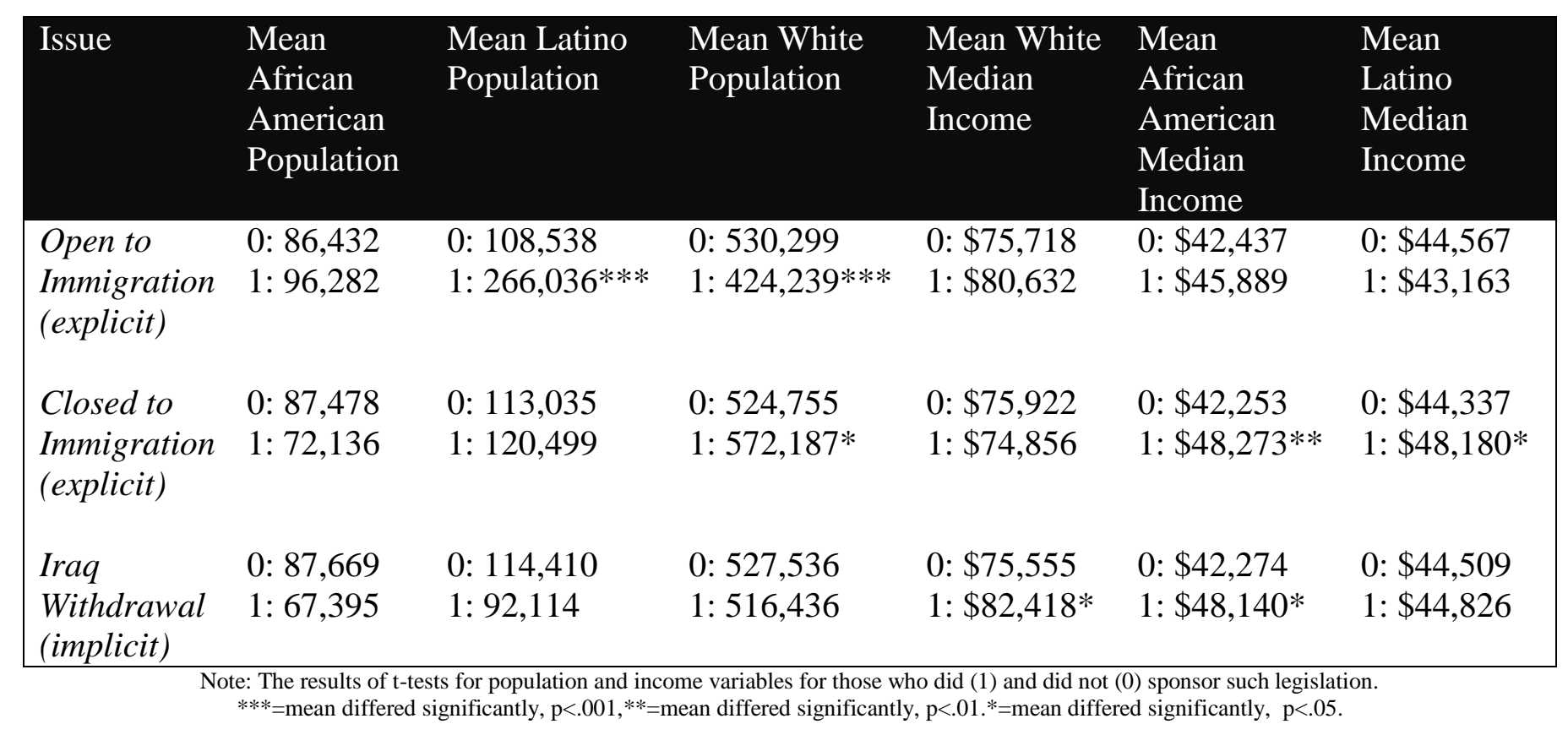


issues, though party is dominant. This impact may become more meaningful as the number of conservative Latinos in Congress grows.

The sponsorship behavior analysis examined both implicitly and explicitly racial issues and showed some differences. Party is a major determinant of sponsorship behavior on both explicitly and implicitly racial issues. However, Latino Democrats are especially active in sponsoring openness to immigration legislation, and unlike white Democrats and Republicans, Latino Democrats and Republicans did not differ significantly in their sponsorship behavior for closed to immigration legislation. Racial differences were not important for Iraq withdrawal legislation. District characteristics mattered: those who sponsored openness to immigration legislation had higher mean Latino populations and lower mean white populations than those who did not, and those who sponsored closed to immigration legislation had higher mean white populations than those who did not. District median income did not behave as a pure theory of responsiveness would predict. This may represent support of the idea that representation is narrow, based more on race and explicitly racial issues than income and implicitly racial issues. While this shows that Grose (2011) is right to urge looking at other forms of congressional behavior beyond voting, it suggests that once substantively important issues are examined by policy dimension, the promise of descriptive representation may not hold the same way for explicitly and implicitly racial issues. It seems that Latino legislators did a better job representing Latinos through sponsorship on explicitly racial issues alone, as the theory of narrow representation predicts.

Another important finding in this chapter is the importance of not only policy type, but direction. "Immigration" was the explicitly racial policy area examined here, 
but only openness to immigration goes in the direction African Americans and Latinos desire. In addition, legislators exhibit very different behavior depending on the direction, with white legislators much more active on closed to immigration policies and Latino legislators extremely important for openness to immigration policy sponsorship. Those who sponsored openness to immigration bills were from districts with more Latinos and fewer whites than those who did not, and those who sponsored closed to immigration bills were from districts with more whites than those who did not. This demonstrates further the importance of policy area, in addition to racialization.

That Democrats are so reliably aligned with Blacks and Latinos in these analyses aligns with the work of King and Smith $(2005 ; 2008)$. They argue that opposing racial “orders," made up of state institutions and other political actors clustered predictably along either "color blind" or "race-conscious" sides of policy debates (King and Smith 2008) explain much more of politics and history than most scholars anticipate. Indeed, they argue these racial orders explain much of the party polarization we see on a majority of political issues. My project represents an attempt to heed their warning that racial politics matters even where one would least expect it (King and Smith 2005). While they demonstrate the importance of racial orders for party politics on two explicitly racial issues, affirmative action and majority-minority districts (King and Smith 2008), the voting and sponsorship behavior analysis here indicates the polarization of these orders may be alive and well for implicitly racial issues too, and in a variety of representational forms.

There are some shortcomings in this analysis that can be improved upon. First, and most obviously, only two implicitly racial issues are examined here for legislator 
voting behavior. The lack of recent opinion data that provides large enough samples of racial populations to examine these group's opinions within income categories, and the lack of action in Congress on any issues, let alone implicitly racial ones, makes it hard to move beyond a few issues. Relatedly, there is no explicitly racial issue more obviously connected to African Americans examined here. To fully understand legislator behavior on implicitly and explicitly racial issues, a wider set of cases is needed. More votes also means more Congresses, and more African American and Latino members in each party, data that would also enable a more thorough interactive examination of party and race in the multivariate analyses.

Second, and also relatedly, there are undoubtedly other explanations beyond those examined here for legislator vote choice on these two bills. For example, the Emergency Economic Stabilization Act, which created TARP, has a complicated legislative history; the bank bailout was coupled with everything from genetics research (in the House) to mental health policy (in the Senate) to make the package more attractive, or perhaps give excuses to representatives worried about the opinions of their constituents (Arnold 1990). This is another reason why an examination of more votes is necessary, when data permit it. I also do not examine opinions at the district level, or low-income voting rates in districts, which are key factors for determining how salient constituent opinion is for a given member of Congress (e.g. Kingdon 1977; Fenno 1978). A simpler explanation may simply be that low-income constituents continue to be ignored - though my analyses suggest that is true not just for white legislators, but African American and Latino legislators as well, which may be interesting for supporters of ensuring descriptive representation. 
Despite these limitations and possible extensions, given the dearth of data that permits examination of low-income Black and Latino opinion, and the inactivity of Congress, this analysis represents a step forward. The consideration of income-group opinions within racial groups is unusual. Examining how members of Congress respond or do not respond to unique desires of the most disadvantaged members of racial groups is even more unusual. This research shows that even though majorities of white, African American, and Latino populations were for the American Taxpayer Relief Act, lowincome African Americans were not, and Democrats voted "no." Similarly, though majorities of white, African American, and Latino populations were against the Troubled Asset Relief Program, low-income Latinos were for it, and Democrats voted "yes." The impact of party was powerful even after considering legislator race and district characteristics, but the hope for descriptive representation may not be not altogether lost: Latino Republicans behaved differently than other Republicans. In addition, Latino Democrats and white Democrats behaved differently in their sponsorship activity on an explicitly racial issue. These are interesting findings that raise new questions for the literature. 


\section{CHAPTER FOUR}

\section{INTRODUCTION}

Descriptive representation seems to yield more concrete dividends when one looks beyond roll call voting (e.g., Grose 2011; Minta 2011; Ellis and Wilson 2013; Minta and Sinclair-Chapman 2013; Minta and Brown 2014). This is especially true for congressional oversight. The positive impact of descriptive representation for substantive oversight activity holds for all racially salient issues, both implicit and explicit (Minta 2011; Ellis and Wilson 2013; Minta and Sinclair-Chapman 2013; Minta and Brown 2014). Minta and Sinclair-Chapman (2013) show that larger numbers of nonwhite legislators in the House coincide with more oversight activity on racially salient issues. Minta (2011) and Ellis and Wilson (2013) turn their attention to committees. Minta (2011) finds that nonwhite committee members participate more actively in racially salient oversight than do white committee members, and Ellis and Wilson (2013) argue that African American and Latino chairs positively impact the volume of racially salient oversight.

However, the effect of the number of African American and Latino committee members upon committee oversight is unexamined. This chapter considers how congressional committee member demographics, and not just the race of committee chairs, may impact racially salient oversight. Kastellec (2013) shows that African American members on appellate benches impact rulings on explicitly racial issues; it stands to reason African American and Latino members on committees might affect oversight on racially salient issues. To explore this question, I create a variable for the count of African Americans and Latinos on standing committees from the $80^{\text {th }}$ through 
the $110^{\text {th }}$ Congresses, and using Policy Agendas Project data, examine how the composition of committees shapes oversight activity on explicitly and implicitly racial issues. I am interested in answering three questions. Do committees with more African American and Latino members engage in higher levels of implicitly and explicitly racial oversight? Are there differences when one differentiates between implicitly and explicitly racial issues? Importantly, how did the increase in majority-minority and the commensurate increase in African American and Latino legislators in the early 1990s affect the oversight behavior of committees? More African Americans and Latinos on committees and in the House might lead to increases in racially salient oversight by committees. Conversely, having fewer Black and Latino constituents might lead white legislators and committee chairs to focus less than before on racially salient issues.

I find that, prior to the $103^{\text {rd }}$ Congress, African American members on committees exerted influence only over whether or not committees held hearings on explicitly racial issues occurred, but not whether they held implicitly racial issues. However, after the $103^{\text {rd }}$ Congress, African Americans on committees greatly influenced the number of implicitly racial hearings committees held, even when only Democratically-led Houses are included. However, there was no concomitant change in the relationship between African American members on committees and committees' explicitly racial oversight. This may reflect changes in focus by mostly white chairs. In any case, approaches to racially salient oversight changed after redistricting. Further, the findings suggest that in the case of oversight, the expectations of narrow representation are swapped over time: African American committee members affected explicitly racial oversight occurrence in the past, but more recently influenced the volume of implicitly racial hearings. Given the 
lack of attention to committee members' races and their effect on oversight activity, this approach constitutes a needed step forward for the literature.

\section{LITERATURE REVIEW AND THEORY BUILDING}

An exploration of the influences of legislator race on congressional responsiveness to Blacks and Latinos is incomplete without an examination of activities beyond roll call voting (e.g., Grose 2011; Minta 2011; Minta and Sinclair-Chapman 2013; Minta and Brown 2014). Grose (2011) emphasizes the importance of constituency service and project delivery, along with roll call voting, as forms of substantive representation. Where members of Congress have more control over activity, descriptive representation will be more meaningful. African American members may not have much control over the roll call agenda, but they do have control over their constituency service, and as such the relevance of legislator race shows itself there, according to Grose. Minta and Sinclair-Chapman (2013) also step away from voting but focus on oversight, and find that increased racial diversity in the House as a whole, relative to the Senate, has increased the number of hearings on explicitly and implicitly racial issues over time.

Minta (2011) delves even further into the oversight arena, finding that nonwhite members of Congress contribute longer and more frequent comments at oversight hearings than white members of Congress on both explicitly racial and social welfare issues. In this work, Minta explores the content of a sample of 55 hearings supporting racially salient interests during the $103^{\text {rd }}, 104^{\text {th }}$, and $107^{\text {th }}$ Congresses. Ellis and Wilson (2013) cast a wider net for hearings addressing racially salient interests, examining 27,000 hearings over 30 years. They, like Minta and Sinclair-Chapman (2013), use the Policy Agendas Project, examining civil rights issues, social welfare issues, and housing 
issues. Their focus is on whether behavior by committees on these issues varies depending on the race of the committee chair, and they find that, indeed, committees with African American and Latino chairs are more active on civil, social welfare, and housing issues.

I approach oversight behavior differently. Specifically, I want to know whether the presence of African American and Latino members on congressional committees increases committee oversight of explicitly and implicitly racial issues. This approach dives into committee demography over a longer time span than previous studies.

Kastellec (2013) shows that the presence of African American justices on appellate courts affects those courts' rulings on affirmative action — an explicitly racial issue. I examine whether the same holds for congressional committee oversight, on not just explicitly racial but also implicitly racial issues. It is reasonable to expect committee membership demography to matter over and above demography of the entire Congress, and the race of the chair. Since 1970s reforms, more authority has been granted to committees and subcommittees, and chairs rely upon their members to continue their chairmanships (e.g., Smith and Deering 1984; Rohde 1991; Schickler, McGhee, and Sides 2003). More generally, Karpowitz, Mendelberg, and Shaker (2012) show that participation by women in group discussions - and their influence on outcomes devised by groups - is influenced not just by the number of women but by the decision rule the group has to follow. This suggests institutional contexts are important.

Secondly, I also attempt to isolate the influence of majority-minority districts on racially salient oversight. The African American and Latino coalitions were much smaller prior to redistricting plans to create more majority-minority districts following 
the 1990 census. This process was sparked by the 1982 amendments to the Voting Rights Act (Lublin 1997), which "require[d] the Department of Justice and the judiciary to examine the effect of electoral laws, including redistricting plans, on minority vote dilution" (Lublin 1997, 6). With the creation of "fifteen new black majority districts and ten new Latino majority districts between 1990 and 1992" (Lublin 1997, 7), the number of African American Members of Congress jumped from 27 in the $102^{\text {nd }}$ Congress to 40 in the $103^{\text {rd }}$ Congress (Lublin 1997, 24-25; Congressional Research Service 2013). The change for Latinos was less dramatic, from 15 Latino members in the $102^{\text {nd }}$ Congress to 20 in the $103^{\text {rd }}$ Congress, but it still represents a larger jump in membership than the steady increase that came in the years prior (Lublin 1999, 24-25; Wasniewski 2008).

The advent of more majority-minority districts constitutes a shock to Congress and its committee system that can be used to assess how the influx of larger numbers of African Americans and Latinos affected congressional oversight. This shock could lead to more racially salient oversight activity. Minta and Sinclair-Chapman (2013) show that more racially diverse membership in the House — without consideration for committee members - meant more racially salient oversight. However, the opposite outcome is also possible once one considers the role of committees rather than the entire House. The committee system, even now but certainly in the $103^{\text {rd }}$ Congress, was headed up by mostly white committee chairs who largely no longer relied upon Black and Latino voters. This could create insulation of white committee chairs from potential voter pressure.

These possible positive or negative effects lead me to differentiate between committee oversight activity before and after the $103^{\text {rd }}$ Congress. Does having more 
African Americans and/or Latinos on committees impact both types of racially salient oversight? Or does the effect of African American and Latino legislators on committees differ when the calculus of white legislators is altered after redistricting? Lublin (1997) worries majority-minority districts negatively impact congressional outputs. One cannot fully understand how redistricting affected congressional outputs without also examining committees. In total, my approach adds a new consideration for descriptive representation and oversight by considering the race of committee members, continues the focus on both explicitly and implicitly racial issues, and considers how committee oversight may have changed after redistricting.

\section{HYPOTHESES}

\section{Hypothesis 1}

Ellis and Wilson (2013) find that committees with Latino and African American chairs engage in more racially salient oversight. I predict this effect will remain even after controlling for the number of African Americans and Latinos on committees.

Chairs rely upon members for their seats (e.g., Smith and Deering 1984; Rohde 1991; Schickler, McGhee, and Sides 2003).

\section{Hypothesis 2}

Minta and Sinclair-Chapman (2013) find that higher percentages of minority membership in the House led to concomitant increases in racially salient oversight in the House. Therefore, higher percentages of Latinos and African Americans in Congress will mean more explicitly and implicitly racial oversight by committees.

\section{$\underline{\text { Hypothesis } 3}$}


Relatedly, I predict more African American and Latino individuals in Congress, due to increases in the number of majority-minority districts between the $102^{\text {nd }}$ and $103^{\text {rd }}$ Congress, will shift racially salient oversight activity. That is, I believe oversight activity will differ before and after the inauguration of the $103^{\text {rd }}$ Congress. This test will help confirm whether the change led to increased racially salient oversight (similar to Hypothesis 1's predictions), or decreased racially salient oversight due to reduced interest in racial issues on the part of white legislators. As Black and Latino voters were removed from white legislators' districts, they may have had less incentive to be responsive to racially salient interests.

\section{Hypothesis 4}

Finally, I predict that increased African American and Latino membership on committees will show a significant, positive relationship with the number of committee hearings held on explicitly and implicitly racial topics, and whether such oversight occurs at all. This is based on the scholarship that descriptive representation matters for substantive representation generally (e.g., Grose 2011; Minta 2011; Minta and SinclairChapman 2013; Minta and Brown 2014), and in oversight (e.g., Ellis and Wilson 2013; Minta and Sinclair-Chapman 2013). However, Hypothesis 4 applies this idea to the question of committee membership specifically.

DATA AND METHOD

Coding Race of Committee Members and Tabulating Racial Composition of Committees 
The key independent variable of interest is the number of African Americans and Latinos on committees. I added member race to a dataset ${ }^{11}$ created from Charles Stewart's Congressional Data Page, ${ }^{12}$ using the Congressional Research Service's “African American Members of the United States Congress: 1870-2008” (2008) and Wasniewski’s "Hispanic Americans in Congress 1822-2012” (2013). I looked up African American and Latino members in those documents, and then created African American and Latino dummy variables, using member identification numbers, to add to the dataset. Then, I captured which committee memberships African American and Latino legislators possessed, by creating indicator variables for each committee assignment held by African American and Latino members. Tabulating these variables by Congress told me which committees had African American and Latino members. From there, I was able to calculate and record the number of African Americans and Latinos, by committee, by Congress, for the $80^{\text {th }}-110^{\text {th }}$ Congresses. I stopped at the $110^{\text {th }}$ Congress only because that is where the authoritative Congressional Research Service document on African American members of Congress ended.

Up to the $102^{\text {nd }}$ Congress, the median number of African Americans on a committee was 2 , with a maximum of 7 , and the median number of Latinos on a committee was 1 , with a maximum of 6 . Including and after the $103^{\text {rd }}$ Congress, the median number of African Americans was 7, with a maximum of 11, and the median number of Latinos was just 2, with a maximum of 9. Figures 1 and 2 track the percentage

\footnotetext{
11 Jason MacDonald's committee member dataset takes congressional data from Charles Stewart's Congressional Data Page and adds committee number variables for members' first, second, third, etc. committee assignments, by member.

12 Garrison Nelson, Committees in the U.S. Congress, 1947-1992, [House/80-102]; Charles Stewart III and Jonathan Woon. Congressional Committee Assignments, 103rd to 114th Congresses, 1993--

2017: [House], [2/08/17]
} 
of committees with African American and Latino members over time. Figure 1 shows that 100 percent of committees had at least one African American member by the $108^{\text {th }}$ Congress, and over 90 percent of committees had at least one African American member by the $105^{\text {th }}$ Congress. Latino membership on committees lagged behind that progress a bit. Latinos were not on 100 percent of committees by the $110^{\text {th }}$ Congress as African Americans were, and did not reach membership on 90 percent of committees until the $108^{\text {th }}$ Congress. This followed a major jump; before then, the highest percentage of committees with Latino members was just over 80 percent in the $104^{\text {th }}$ Congress. This may affect the influence of Latinos on committees, relative African Americans.

\section{Figure 1}

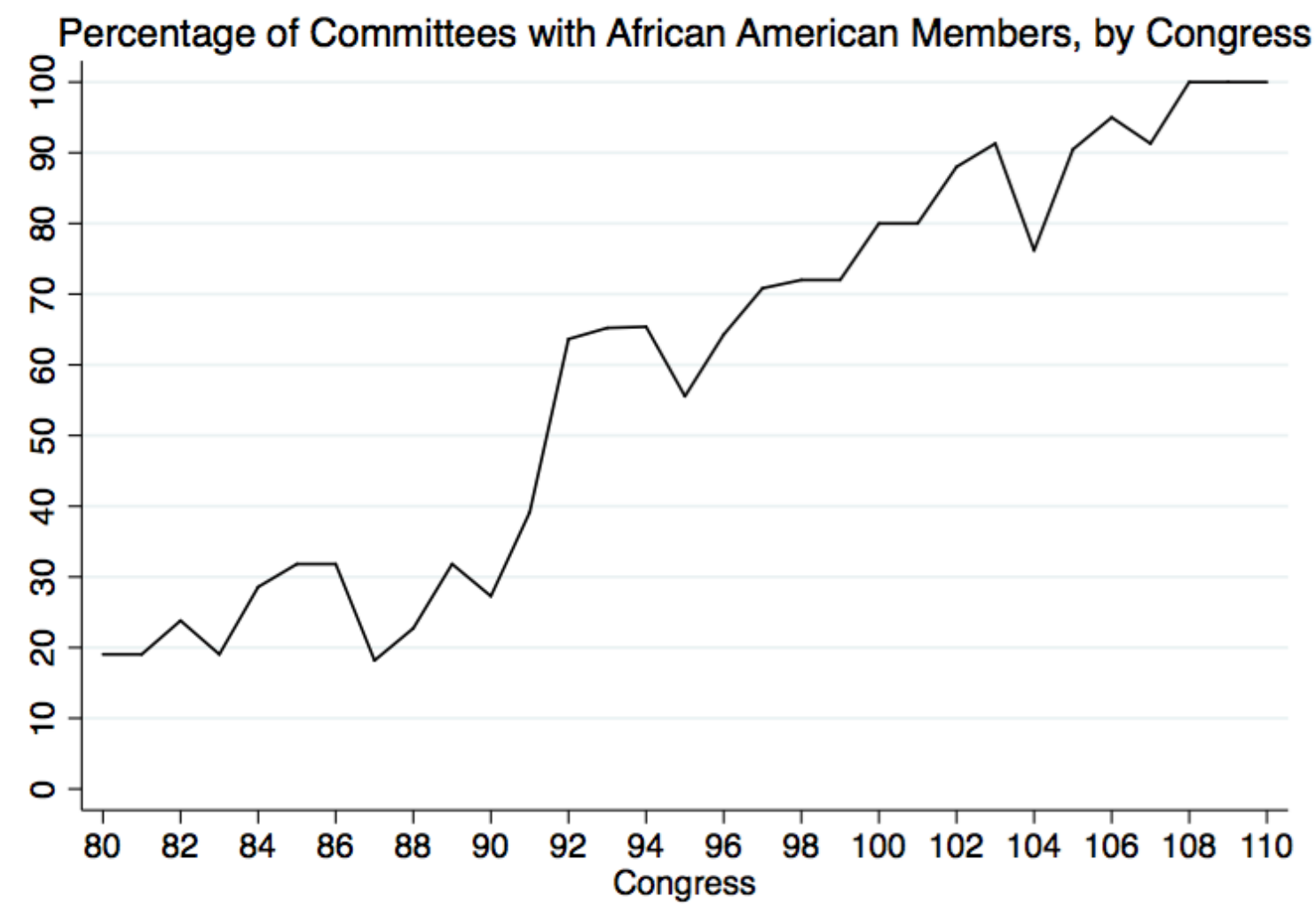

Unit of Analysis and Committees Included 
The unit of analysis is the congressional-committee pair (e.g. $80^{\text {th }}$ CongressAgriculture; $81^{\text {st }}$ Congress-Armed Services), and there are 707 total observations. I included standing committees, and select or special committees that later became standing committees, unless a committee not fitting those parameters was chaired by an African American or Latino. These additional committees beyond the list of standing committees included Hunger, Aging, Intelligence, Narcotics, Assassinations, and Ethics. I made this exception for committees chaired by African Americans and Latinos because

\section{Figure 2}

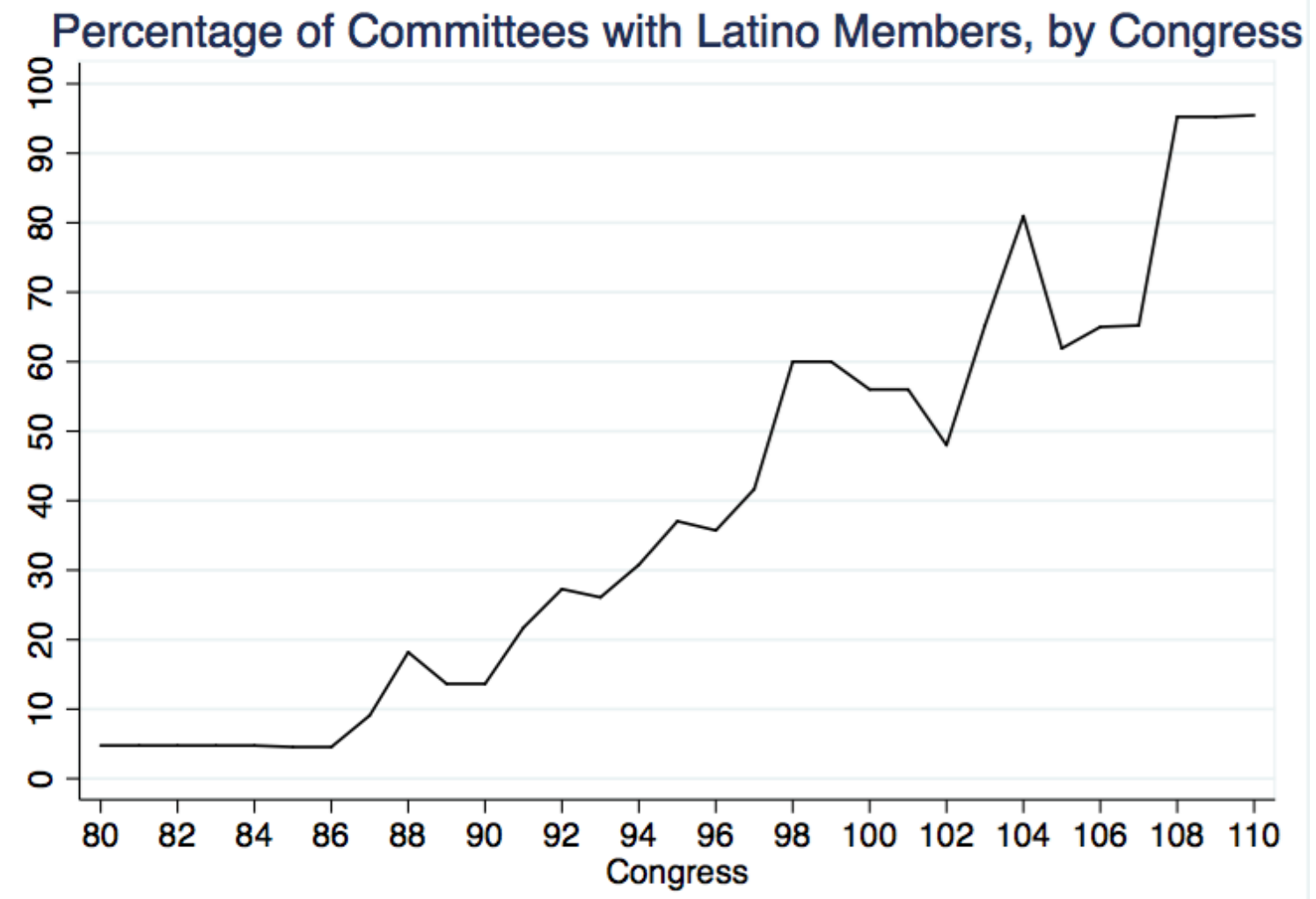

of Ellis and Wilson's (2013) findings. One of my key questions is whether the racial composition of the entire committee, rather than just the race of the chair, matters. By adding more committees chaired by African Americans and Latinos to the sample, I am giving the chair race variables a stronger chance to compete with committee membership. 
I did not code hearings by subcommittees or other committees. Table 1 lists the names of committees included in the analysis.

\section{Explicitly and Implicitly Racial Hearing Topics}

Separate regressions are run for hearings on implicitly racial topics and for hearings on explicitly racial topics. These topics and hearings were selected from the Policy Agendas Project. ${ }^{13}$ Explicitly racial issues include general civil rights, racial discrimination, voting rights, migrant policy, and immigration. Implicitly racial issues include unemployment, unemployment insurance, health reform, health insurance, children's health insurance, labor unions, minimum wage, education for the underprivileged, air pollution, indoor air pollution, infrastructure employment, prisons, general social welfare, low-income assistance, community development, urban development, rural housing, rural development, low-income housing, homelessness, mortgages, small business, and disaster relief. This process left me with 77 explicitly racial hearings and 460 implicitly racial hearings up through the $102^{\text {nd }}$ Congress, and 67 explicitly racial hearings and 428 implicitly racial hearings after the $103^{\text {rd }}$ Congress. The overall oversight activity on racially salient issues is quite small, only 10 percent of all oversight $(9,967$ hearings $)$ conducted by the included committees. Importantly, I code only for the topic area, to gather just the volume of such hearings. I do not code the details of a given hearing or its policy direction, though this is an important area for future research.

13 "The data used here were originally collected by Frank R. Baumgartner and Bryan D. Jones, with the support of National Science Foundation grant numbers SBR 9320922 and 0111611, and are distributed through the Department of Government at the University of Texas at Austin. Neither NSF nor the original collectors of the data bear any responsibility for the analysis reported here." 
Eighty-three Congress-committee pairs held hearings on explicitly racial issues, with the number of hearings by committee on such issues ranging from 1 to a maximum of 9. Two hundred and thirty-three Congress-committee pairs held hearings on implicitly racial issues, with the number of hearings by committee on such issues ranging from 1 to a maximum of 54.

Table 1: List of Committee Names Included in the Analysis

\begin{tabular}{|c|c|c|}
\hline Agriculture & $\begin{array}{l}\text { Government } \\
\text { Operations }\end{array}$ & Public Works \\
\hline Appropriations & Government Reform & $\begin{array}{l}\text { Public Works and } \\
\text { Transportation }\end{array}$ \\
\hline Armed Services & $\begin{array}{l}\text { Government Reform } \\
\text { and Oversight }\end{array}$ & Resources \\
\hline Assassinations & Homeland Security & Rules \\
\hline $\begin{array}{l}\text { Astronautics and } \\
\text { Space Exploration }\end{array}$ & House Administration & Science \\
\hline Banking and Currency & House Oversight & $\begin{array}{l}\text { Science and } \\
\text { Astronautics }\end{array}$ \\
\hline $\begin{array}{l}\text { Banking and Financial } \\
\text { Services }\end{array}$ & Hunger & $\begin{array}{l}\text { Science and } \\
\text { Technology }\end{array}$ \\
\hline $\begin{array}{l}\text { Banking, Finance, and } \\
\text { Urban Affairs }\end{array}$ & Insular Affairs & $\begin{array}{l}\text { Science, Space, and } \\
\text { Technology }\end{array}$ \\
\hline Budget & Intelligence & Small Business \\
\hline Commerce & $\begin{array}{l}\text { Interior and Insular } \\
\text { Affairs }\end{array}$ & $\begin{array}{l}\text { Standards of Official } \\
\text { Conduct }\end{array}$ \\
\hline $\begin{array}{l}\text { Congressional } \\
\text { Operations }\end{array}$ & Internal Security & $\begin{array}{l}\text { Transportation and } \\
\text { Infrastructure }\end{array}$ \\
\hline District of Columbia & $\begin{array}{l}\text { International } \\
\text { Relations }\end{array}$ & $\begin{array}{l}\text { Un-American } \\
\text { Activities }\end{array}$ \\
\hline
\end{tabular}




\begin{tabular}{|lll|}
\hline $\begin{array}{l}\text { Economic and } \\
\text { Educational } \\
\text { Opportunities }\end{array}$ & $\begin{array}{l}\text { Interstate and Foreign } \\
\text { Commerce }\end{array}$ & Veterans' Affairs \\
Education and Labor & Judiciary & Ways and Means \\
$\begin{array}{l}\text { Education and the } \\
\text { Workforce }\end{array}$ & $\begin{array}{l}\text { Merchant Marine and } \\
\text { Education and }\end{array}$ & Fisheries \\
Workforce & Narcotics Abuse and \\
Energy and & Control \\
Commerce & National Security \\
Ethics & \\
Expenditures in the & Oversight and \\
Executive & Government Reform \\
Departments & & \\
Financial Services & Post Office and Civil \\
Foreign Affairs & Service \\
& Public Lands \\
\hline
\end{tabular}

\section{Isolating Redistricting}

I run separate regressions for explicitly and implicitly racial oversight, and, importantly, within those issue areas, I run a full model for the $80^{\text {th }}$ through $110^{\text {th }}$ Congresses, as well as models for the $80^{\text {th }}$ through the $102^{\text {nd }}$ Congresses, and the $103^{\text {rd }}$ through the $110^{\text {th }}$ Congresses. This way, I can examine the influence of the predictors before and after widespread creation of majority-minority districts, which significantly increased numbers of African Americans and Latinos in Congress from the $103^{\text {rd }}$ Congress on. Chow tests confirm whether or not this separation is valid.

I run both logit and negative binomial analyses, to account for the impacts of variables on some versus no racially salient oversight activity, and then the cumulative 
amount of such activity. The negative binomial model is better than poisson due to overdispersion in the data, and Vuong tests indicated zero-inflated negative binomial models are not preferred over negative binomial models in these analyses.

\section{Other Independent Variables and Controls}

I include African American and Latino chairmanship, obtained from "African American Members of the United States Congress: 1870-2008" (Congressional Research Service 2008) and "Hispanic Americans in Congress 1822-2012" (Wasniewski 2013) to discover whether chairmanship or committee demographic composition is more influential. I also include the percentage of combined Latino and African American membership in the House. This variable is multiplied by 100. The largest number of Latinos in a Congress from the $80^{\text {th }}$ through $110^{\text {th }}$ Congresses is 27 , while the highest number of African Americans in the House at any point in the dataset is 42 . Because Democrats might be anticipated to be more responsive on racially salient issues, I include whether the House and presidency were controlled by Democrats, and also run the models for Democratically-led Houses only.

Finally, I include the mean chamber ideology for each Congress, from Poole and Rosenthal's VoteView database. This is a House-level variable, included in Minta and Sinclair-Chapman's (2013) analysis. There is a possibility the House became more liberal or conservative toward issues over time, which could affect oversight topics. Committee-level ideology is also highly relevant and will be included in future research.

\section{$\underline{\text { RESULTS }}$}

The results indicate that there are different factors at play for explicitly and implicitly racial oversight, and before and after the $103^{\text {rd }}$ Congress, especially for 
implicitly racial issues. Tables $1 \mathrm{a}$ and $1 \mathrm{~b}$ examine oversight of explicitly racial issues, while tables $2 \mathrm{a}$ and $2 \mathrm{~b}$ examine oversight of implicitly racial issues.

Consider explicitly racial oversight. Table 1a displays analyses for logit models where the dependent variable is 0 for no hearings by a committee, and 1 for one or more hearings. Column 2 considers the full models for each oversight type, while Columns 3 and 4 differentiate between the $80^{\text {th }}$ through $102^{\text {nd }}$ Congresses (Column 3 ) and the $103^{\text {rd }}$ through $110^{\text {th }}$ Congresses (Column 4), to examine the potential influence of new majority-minority districts after early 1990s redistricting. The full model shows that only the number of African Americans on a committee, the presence of a Latino chair on a committee, and a Democratically-controlled House are significant. As the second and third models show, this is true only up to the $102^{\text {nd }}$ Congress. Up to the $102^{\text {nd }}$ Congress, the addition of an African American member to a committee increases the log odds of a committee's engaging in explicitly racial oversight by 0.3152 . That means with each additional African American member on a committee, there is a 37 percent increase in the likelihood of engaging in some explicitly racial oversight versus none. The effect of having a Latino chair (but not an African American chair once African American members are accounted for) is strong, with the log odds of committees engaging in explicitly racial oversight increasing by 2.4787 when a chair is Latino.

However, this changes after the $103^{\text {rd }}$ Congress, when only the percent African American and Latino membership in the House is (marginally) significant, $\mathrm{p}=0.054$. When the transformation of the percentage African American and Latino membership variable is accounted for, the results show that each 1 percent increase in their 
membership in the House creates a 0.92 percent increase in the likelihood of committees engaging in explicitly racial oversight.

Table 1a: Oversight on Explicitly Racial Issues_-Logit Analysis

\begin{tabular}{|c|c|c|c|}
\hline Variables & $\begin{array}{l}\text { Full Model; } 80^{\text {th }}- \\
110^{\text {th }} \text { Congresses }\end{array}$ & $\begin{array}{l}80^{\text {th }}-102^{\text {nd }} \text { Congress } \\
\text { Model }\end{array}$ & $\begin{array}{l}103^{\text {rd }}-110^{\text {th }} \\
\text { Congress } \\
\text { Model }\end{array}$ \\
\hline $\begin{array}{c}\text { \# African } \\
\text { Americans on } \\
\text { Committee } \\
\end{array}$ & $\begin{array}{l}0.1407 * \\
(0.069)\end{array}$ & $\begin{array}{l}0.3152^{*} \\
(0.139)\end{array}$ & $\begin{array}{l}0.1034 \\
(0.085)\end{array}$ \\
\hline $\begin{array}{l}\text { \# Latinos on } \\
\text { Committee }\end{array}$ & $\begin{array}{l}0.0759 \\
(0.095)\end{array}$ & $\begin{array}{l}0.1484 \\
(0.172)\end{array}$ & $\begin{array}{l}0.0035 \\
(0.122)\end{array}$ \\
\hline $\begin{array}{c}\text { \% Minority } \\
\text { Members in } \\
\text { Congress }\end{array}$ & $\begin{array}{l}0.0317 \\
(0.032)\end{array}$ & $\begin{array}{l}0.0716 \\
(0.118)\end{array}$ & $\begin{array}{l}0.6529^{\wedge} \\
(0.338)\end{array}$ \\
\hline $\begin{array}{c}\text { African American } \\
\text { Chair }\end{array}$ & $\begin{array}{l}0.6456 \\
(0.395)\end{array}$ & $\begin{array}{l}0.3238 \\
(0.502)\end{array}$ & $\begin{array}{l}0.5095 \\
(0.898)\end{array}$ \\
\hline $\begin{array}{l}\text { Latino } \\
\text { Chair }\end{array}$ & $\begin{array}{c}1.8371 * * \\
(0.536)\end{array}$ & $\begin{array}{c}2.4787 * * * * \\
(0.672)\end{array}$ & $\begin{array}{l}0.1153 \\
(1.262)\end{array}$ \\
\hline Democratic House & $\begin{array}{c}-0.6076^{*} \\
(0.269)\end{array}$ & $\begin{array}{c}-1.3715^{*} \\
(0.624)\end{array}$ & $\begin{array}{l}-0.1173 \\
(0.5256)\end{array}$ \\
\hline $\begin{array}{c}\text { Democratic } \\
\text { President }\end{array}$ & $\begin{array}{l}-0.3332 \\
(0.264)\end{array}$ & $\begin{array}{l}0.0548 \\
(0.391)\end{array}$ & $\begin{array}{c}0.2270 \\
(0.6538)\end{array}$ \\
\hline Constant & $\begin{array}{l}-2.30^{* * *} \\
(0.3)\end{array}$ & $\begin{array}{c}-2.37 * * * \\
(0.370)\end{array}$ & $\begin{array}{l}-11.37^{*} \\
(5.119)\end{array}$ \\
\hline $\begin{array}{l}\text { Number of } \\
\text { observations }\end{array}$ & 707 & 535 & 172 \\
\hline Log-Likelihood & $-236.77 * * *$ & $-149.93 * *$ & -80.08 \\
\hline
\end{tabular}

Note: The dependent variables are explicit hearings by committees (unit of analysis is the committee-Congress pair), where $0=$ no hearings and $1=1$ or more hearings. Entries are $\log$ odds; standard errors are in parentheses.

$* * *=\mathrm{p}<0.001{ }^{* *}=\mathrm{p}<0.01 *=\mathrm{p}<0.05^{\wedge}=\mathrm{p}<0.054$ 
Table 1b: Oversight on Explicitly Racial Issues_-Negative Binomial Analysis

\begin{tabular}{|c|c|c|c|}
\hline Variables & $\begin{array}{l}\text { Full Model; } 80^{\text {th }}- \\
110^{\text {th }} \text { Congresses }\end{array}$ & $\begin{array}{l}80^{\text {th }}-102^{\text {nd }} \text { Congress } \\
\text { Model }\end{array}$ & $\begin{array}{l}103^{\text {rd }}-110^{\text {th }} \\
\text { Congress } \\
\text { Model }\end{array}$ \\
\hline $\begin{array}{c}\text { \# African } \\
\text { Americans on } \\
\text { Committee }\end{array}$ & $\begin{array}{l}0.1185 \\
(0.079)\end{array}$ & $\begin{array}{l}0.2599 \\
(0.159)\end{array}$ & $\begin{array}{r}0.1207 \\
(0.088)\end{array}$ \\
\hline $\begin{array}{l}\text { \# Latinos on } \\
\text { Committee }\end{array}$ & $\begin{array}{l}0.0027 \\
(0.108)\end{array}$ & $\begin{array}{l}0.0656 \\
(0.220)\end{array}$ & $\begin{array}{l}-0.0924 \\
(0.117)\end{array}$ \\
\hline $\begin{array}{c}\text { \% Minority } \\
\text { Members in } \\
\text { Congress }\end{array}$ & $\begin{array}{l}0.0507 \\
(0.032)\end{array}$ & $\begin{array}{l}-0.0476 \\
(0.121)\end{array}$ & $\begin{array}{c}0.9972 * * \\
(0.339)\end{array}$ \\
\hline $\begin{array}{c}\text { African American } \\
\text { Chair }\end{array}$ & $\begin{array}{l}0.7221 \\
(0.425)\end{array}$ & $\begin{array}{l}0.5338 \\
(0.563)\end{array}$ & $\begin{array}{l}0.3669 \\
(0.871)\end{array}$ \\
\hline $\begin{array}{c}\text { Latino } \\
\text { Chair }\end{array}$ & $\begin{array}{l}1.3875^{*} \\
(0.693)\end{array}$ & $\begin{array}{l}2.2421^{* *} \\
(0.868)\end{array}$ & $\begin{array}{l}-0.7709 \\
(1.444)\end{array}$ \\
\hline Democratic House & $\begin{array}{l}-0.6067 \\
(0.274)\end{array}$ & $\begin{array}{c}-0.4648 \\
(0.561)\end{array}$ & $\begin{array}{l}-0.1945 \\
(0.531)\end{array}$ \\
\hline $\begin{array}{c}\text { Democratic } \\
\text { President }\end{array}$ & $\begin{array}{l}0.0126 \\
(0.285)\end{array}$ & $\begin{array}{l}0.4577 \\
(0.424)\end{array}$ & $\begin{array}{l}0.4387 \\
(0.673)\end{array}$ \\
\hline Constant & $\begin{array}{l}-2.08 * * * \\
(0.317)\end{array}$ & $\begin{array}{l}-2.15 * * * \\
(0.416)\end{array}$ & $\begin{array}{c}-16.05 * * \\
(5.19)\end{array}$ \\
\hline $\begin{array}{l}\text { Number of } \\
\text { observations }\end{array}$ & 707 & 535 & 172 \\
\hline Log-Likelihood & $-339.37 * *$ & -206.60 & $-121.88 * *$ \\
\hline
\end{tabular}

Note: The dependent variables are explicit hearing counts by committees (unit of analysis is the committee-Congress pair). Entries are logs of expected counts; standard errors are in parentheses.

$* * *=\mathrm{p}<0.001 * *=\mathrm{p}<0.01 *=\mathrm{p}<0.05$

However, as Figure 3 demonstrates, the relationship between African American committee members and explicitly racial oversight before redistricting is not very noticeably different from that relationship after. A Chow test comparing the effect of the number of African Americans on a committee upon the likelihood of explicitly racial oversight for the two samples, before and after redistricting, has a p-value of 0.6997. 
Correspondingly, a difference of slope test for the effects of the variable in the two sets of regressions, before and after redistricting, is 1.3 , which is not significant for 703 degrees of freedom $(\mathrm{p}=0.9030)$. This indicates there is no significant difference in the way the number of African Americans on the committee affected explicitly racial oversight before and after the $103^{\text {rd }}$ Congress. The lack of significance of the log likelihood in the third model also suggests the model for explicitly racial oversight after redistricting may be missing other key influences upon explicitly racial oversight.

As a precaution, Appendix $\mathrm{H}$ examines whether having at least one African American on a committee is what matters for explicitly racial oversight, rather than increasing numbers of African Americans on committees. In no case, though, was a dummy variable for the presence of an African American on a committee (or a dummy variable for the presence of a Latino on a committee), rather than a count variable, significant for whether committees held explicitly racial hearings.

\section{Figure 3}
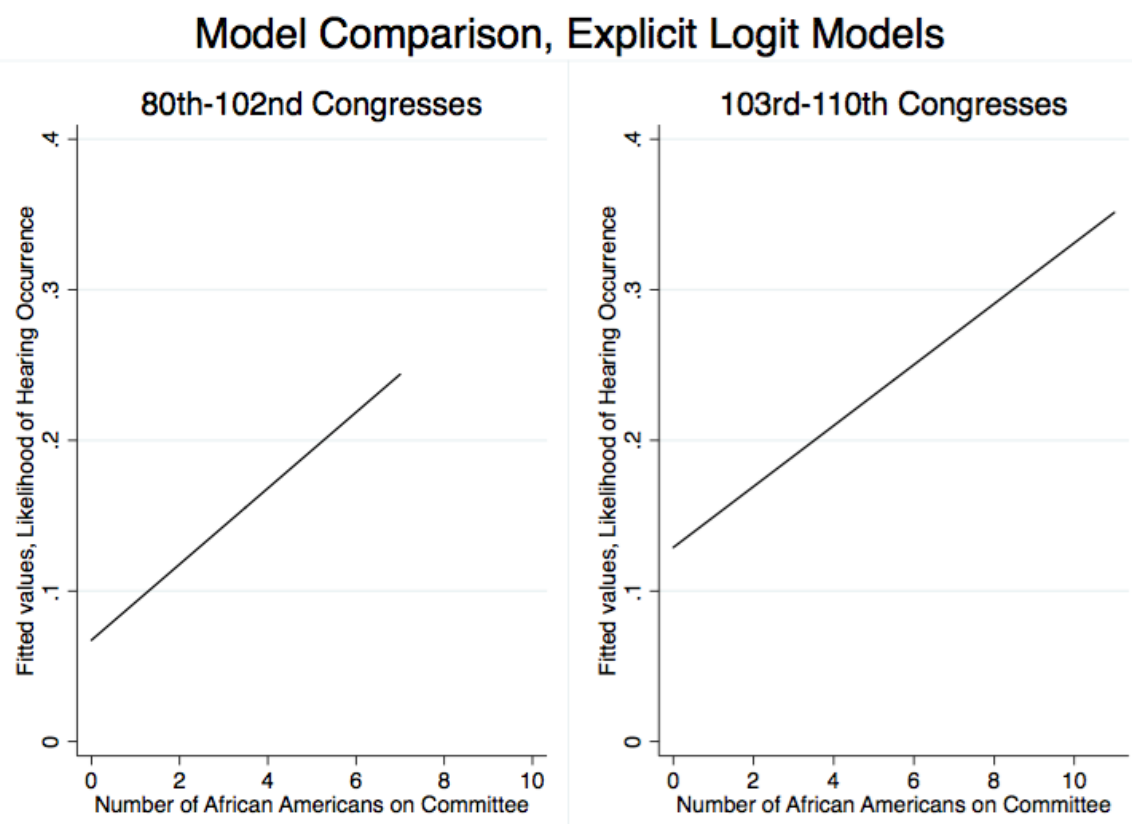
Another possible consideration for explicitly racial oversight occurrence is that Republicans controlled Congress for much of the time after the $103^{\text {rd }}$ Congress (all but two sessions). Perhaps that explains the lack of influence by African American committee members upon explicitly racial oversight after the $103^{\text {rd }}$ Congress. Table $3 \mathrm{a}$ shows that considering only Democratically-controlled Houses does not dramatically change the findings for explicitly racial oversight, however. In addition, a difference of slope test for the influence of African American committee members upon the occurrence of explicitly racial oversight is 0.54 , which is not significant at 534 degrees of freedom $(p=0.7053)$. Again, the log-likelihood suffers in the third model in table $3 a$, as does the number of observations; a larger sample of Democratic Houses after redistricting is needed to fully explore this question. In any case, while there is a relationship between the number of African Americans on committees and the occurrence of explicitly racial oversight in the pooled model, there is no significant difference in the influence of that variable before and after the $103^{\text {rd }}$ Congress.

Table $1 \mathrm{~b}$, containing negative binomial coefficients, shows that when considering the count of explicitly racial oversight hearings, rather than whether or not some versus no oversight happened, the findings are different: up through the $102^{\text {nd }}$ Congress, only Latino chairmanship, and not the number of African Americans on committees, has an impact this time. After the $103^{\text {rd }}$ Congress, the percentage African American and Latino membership in the House remains influential and no longer marginal. With each 1 percent increase in the percentage African American and Latino membership in the House, the expected number of explicitly racial hearings engaged in by committees goes up 1.71 percent. After controlling for the number of African Americans on committees, 
African American chairmanship is still not significant, nor is the number of Latinos on the committee, or whether the House and presidency are in Democratic control. It is important to note, however, that the log-likelihood in the second model misses significance. Clearly, there is still much to discover about what drives explicitly racial oversight by committees; it is likely more committee-level variables are needed. The difference between the binary logit and negative binomial findings may also be partially due to the low count of explicitly racial hearings discussed earlier: the highest number of explicitly racial hearings held by committees, by Congress, is just 9 for the whole dataset.

As for why an influx of new African American and Latino committee members does not seem to have a large impact upon explicitly racial oversight, it is possible that organization and focus on explicitly racial issues moved to a more chamber-wide perspective, rather than committee-based. This may explain the influence of the percent African American and Latino membership variable after redistricting. Moreover, it may also be the case that committee chairs—-still mostly white even now in the $115^{\text {th }}$ Congress - felt no reason to give explicitly racial issues special concern after their district compositions changed. The lack of impact for Latino members on committees, meanwhile, and continued influence of Latino chairs rather than African American chairs, may be due to their lower numbers on committees, relative African Americans, throughout the dataset (see Figures 1 and 2). Larger numbers of African Americans and Latinos on committees may coincide with African American and Latino chairmanship. Correspondingly, given the smaller numbers of Latinos, this may mean the influence of African American members reduces the significance of African American chairs for 
racially salient oversight, but that there are not yet enough Latinos to reduce the significance of Latino chairs.

What about implicitly racial oversight? First, consider the logit models in Table 2a. Here, there is a major difference after the $103^{\text {rd }}$ Congress. Up to the $102^{\text {nd }}$ Congress, unlike explicitly racial oversight in the logit model, there is no impact for either the number of African Americans or Latinos on committees - only Latino chairmanship has an effect. However, after the $103^{\text {rd }}$ Congress, in direct contrast to what happened with the explicit model, there is now an impact for the number of African Americans on committees and whether committees engage in implicitly racial oversight: as the number of African Americans on committees increases, the likelihood of a committee engaging in implicitly racial oversight increases by 48 percent.

The negative binomial model in Table $2 \mathrm{~b}$ is more meaningful for implicitly than explicitly racial hearings, because the highest count for implicitly racial oversight hearings by a committee in the dataset is 54 (rather than 9 for explicitly racial oversight). When hearing count is considered in Table $2 b$, there is still only an influence for the number of African Americans on committees including and after the $103^{\text {rd }}$ Congress. This difference is much more striking than the difference redistricting causes for explicitly racial issues (Chow test $\mathrm{p}<0.001$; difference of slope test $\mathrm{p}=0.0036$ ). Figures 4 and 5 show the dramatic difference the number of African American committee members had upon the amount of implicitly racial hearings by committees before and after 1990s redistricting. For the model that examines the $80^{\text {th }}-102^{\text {nd }}$ Congresses, increasing the number of African American committee members has a very flat effect upon the number of implicitly racial oversight hearings. For the $103^{\text {rd }}$ through $110^{\text {th }}$ Congresses, the effect 
of adding African American committee members increases the amount of implicitly racial oversight by committees drastically. In addition, in table $2 b$, the log likelihood is significant for all three models.

Table 2a: Oversight on Implicitly Racial Issues-Logit Analysis

\begin{tabular}{|c|c|c|c|}
\hline Variables & $\begin{array}{c}\text { Full Model; } 80^{\text {th }}- \\
110^{\text {th }} \text { Congresses }\end{array}$ & $\begin{array}{l}80^{\text {th }}-102^{\text {nd }} \text { Congress } \\
\text { Model }\end{array}$ & $\begin{array}{l}103^{\text {rd }}-110^{\text {th }} \\
\text { Congress } \\
\text { Model }\end{array}$ \\
\hline $\begin{array}{c}\text { \# African } \\
\text { Americans on }\end{array}$ & $0.2353^{* * *}$ & 0.0871 & $0.3941^{* * *}$ \\
Committee & $(0.056)$ & $(0.092)$ & $0.087)$ \\
\hline \# Latinos on & -0.0411 & -0.2037 & $(0.104)$ \\
Committee & $(0.076)$ & $(0.134)$ & 0.3147 \\
\hline \% Minority & -0.0235 & -0.0329 & $(0.281)$ \\
Members in & $(0.023)$ & $(0.064)$ & -0.7094 \\
Congress & 0.1501 & 0.380 & $(0.931)$ \\
\hline African American & $(0.296)$ & $(0.329)$ & 0.8114 \\
Chair & $1.191 *$ & $1.2038^{*}$ & $(1.265)$ \\
\hline Latino Chair & $(0.503)$ & $(0.585)$ & 0.2131 \\
& -0.2334 & -0.0289 & $(0.462)$ \\
\hline Democratic House & $(0.172)$ & $(0.316)$ & -0.4772 \\
& -0.096 & 0.0133 & $(0.511)$ \\
\hline Democratic & $(0.172)$ & $(0.228)$ & -6.15 \\
President & $-0.78^{* * *}$ & $-0.75 * *$ & $(4.3)$ \\
\hline Constant & $(0.193)$ & $(0.228)$ & 172 \\
\hline Number of & 707 & 535 & $-97.95^{* * *}$ \\
\hline Lbservations & $-433.38^{* *}$ & -324.36 & \\
\hline
\end{tabular}

Note: The dependent variables are implicit hearings by committees (unit of analysis is the committee-Congress pair), where $0=$ no hearings and $1=1$ or more hearings. Entries are $\log$ odds; standard errors are in parentheses. $*^{* *}=\mathrm{p}<0.001 * *=\mathrm{p}<0.01 *=\mathrm{p}<0.05^{\wedge}=\mathrm{p}<0.054$ 
Table 2b: Oversight on Implicitly Racial Issues-Negative Binomial Analysis

\begin{tabular}{|c|c|c|c|}
\hline Variables & $\begin{array}{l}\text { Full Model; } 80^{\text {th }}- \\
110^{\text {th }} \text { Congresses }\end{array}$ & $\begin{array}{l}80^{\text {th }}-102^{\text {nd }} \text { Congress } \\
\text { Model }\end{array}$ & $\begin{array}{l}103^{\text {rd }}-110^{\text {th }} \\
\text { Congress } \\
\text { Model }\end{array}$ \\
\hline $\begin{array}{c}\text { \# African } \\
\text { Americans on } \\
\text { Committee }\end{array}$ & $\begin{array}{c}0.2498^{* * *} \\
(0.059)\end{array}$ & $\begin{array}{l}0.0825 \\
(0.103)\end{array}$ & $\begin{array}{c}0.4443 * * * \\
(0.086)\end{array}$ \\
\hline $\begin{array}{l}\text { \# Latinos on } \\
\text { Committee }\end{array}$ & $\begin{array}{l}0.0634 \\
(0.089)\end{array}$ & $\begin{array}{l}-0.0326 \\
(0.159)\end{array}$ & $\begin{array}{l}0.1215 \\
(0.114)\end{array}$ \\
\hline $\begin{array}{c}\text { \% Minority } \\
\text { Members in } \\
\text { Congress }\end{array}$ & $\begin{array}{l}-0.0144 \\
(0.025)\end{array}$ & $\begin{array}{l}-0.0152 \\
(0.062)\end{array}$ & $\begin{array}{l}-0.0179 \\
(0.244)\end{array}$ \\
\hline $\begin{array}{c}\text { African American } \\
\text { Chair }\end{array}$ & $\begin{array}{c}-0.0378 \\
(0.312)\end{array}$ & $\begin{array}{l}0.2104 \\
(0.348)\end{array}$ & $\begin{array}{l}-1.222 \\
(0.855)\end{array}$ \\
\hline Latino Chair & $\begin{array}{l}1.692 * * \\
(0.506)\end{array}$ & $\begin{array}{c}1.5757^{* *} \\
(0.601)\end{array}$ & $\begin{array}{l}0.9466 \\
(1.011)\end{array}$ \\
\hline Democratic House & $\begin{array}{l}-0.1711 \\
(0.182)\end{array}$ & $\begin{array}{l}0.0139 \\
(0.318)\end{array}$ & $\begin{array}{l}0.0468 \\
(0.415)\end{array}$ \\
\hline $\begin{array}{l}\text { Democratic } \\
\text { President }\end{array}$ & $\begin{array}{l}-0.2899 \\
(0.189)\end{array}$ & $\begin{array}{l}-0.2577 \\
(0.252)\end{array}$ & $\begin{array}{l}-0.8736 \\
(0.481)\end{array}$ \\
\hline Constant & $\begin{array}{c}-0.20 \\
(0.214)\end{array}$ & $\begin{array}{c}-0.19 \\
(0.255)\end{array}$ & $\begin{array}{l}-0.72 \\
(3.65)\end{array}$ \\
\hline $\begin{array}{l}\text { Number of } \\
\text { observations }\end{array}$ & 706 & 535 & 171 \\
\hline Log-Likelihood & $-892.30 * * *$ & $-611.59 *$ & $-271.46 * * *$ \\
\hline
\end{tabular}

Note: The dependent variables are implicit hearing counts by committees (unit of analysis is the committee-Congress pair). Entries are logs of expected counts; standard errors are in parentheses.

$* * *=p<0.001 * *=p<0.01 *=p<0.05$ 
Figure 4

Model Comparison, Implicit Negative Binomial Models
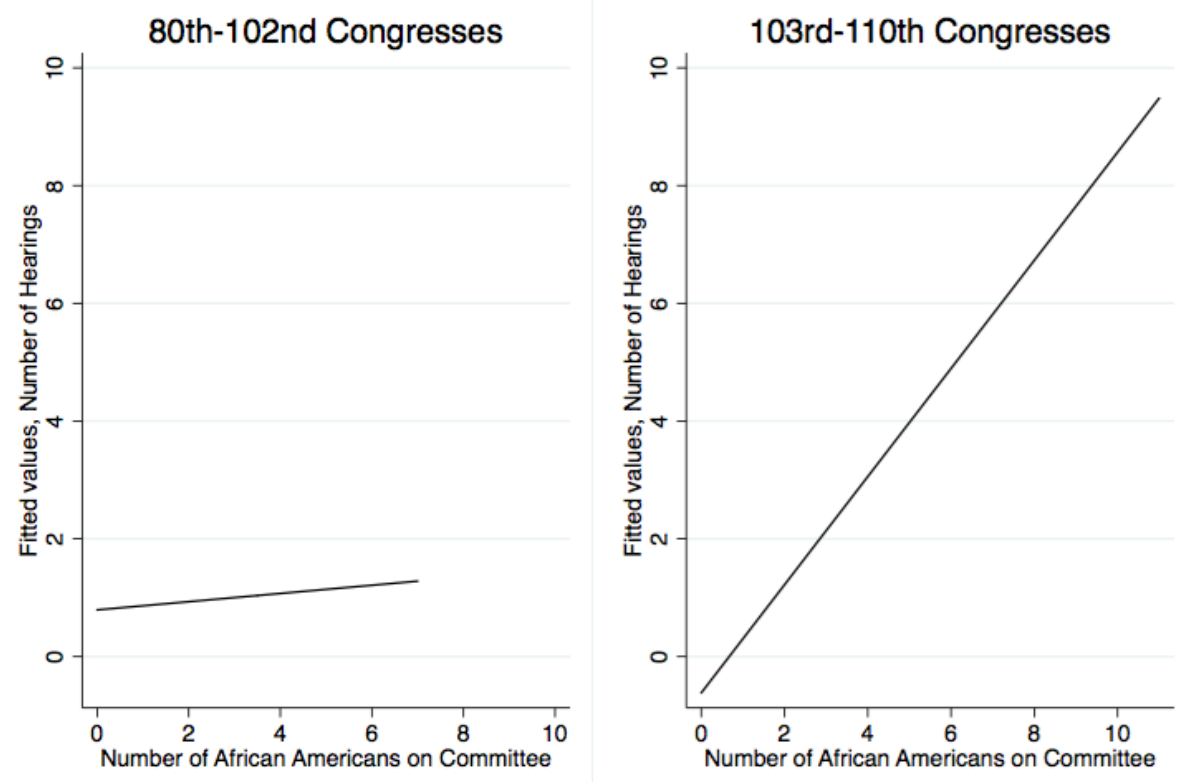

Figure 5

African American Committee Members and Implicit Oversight
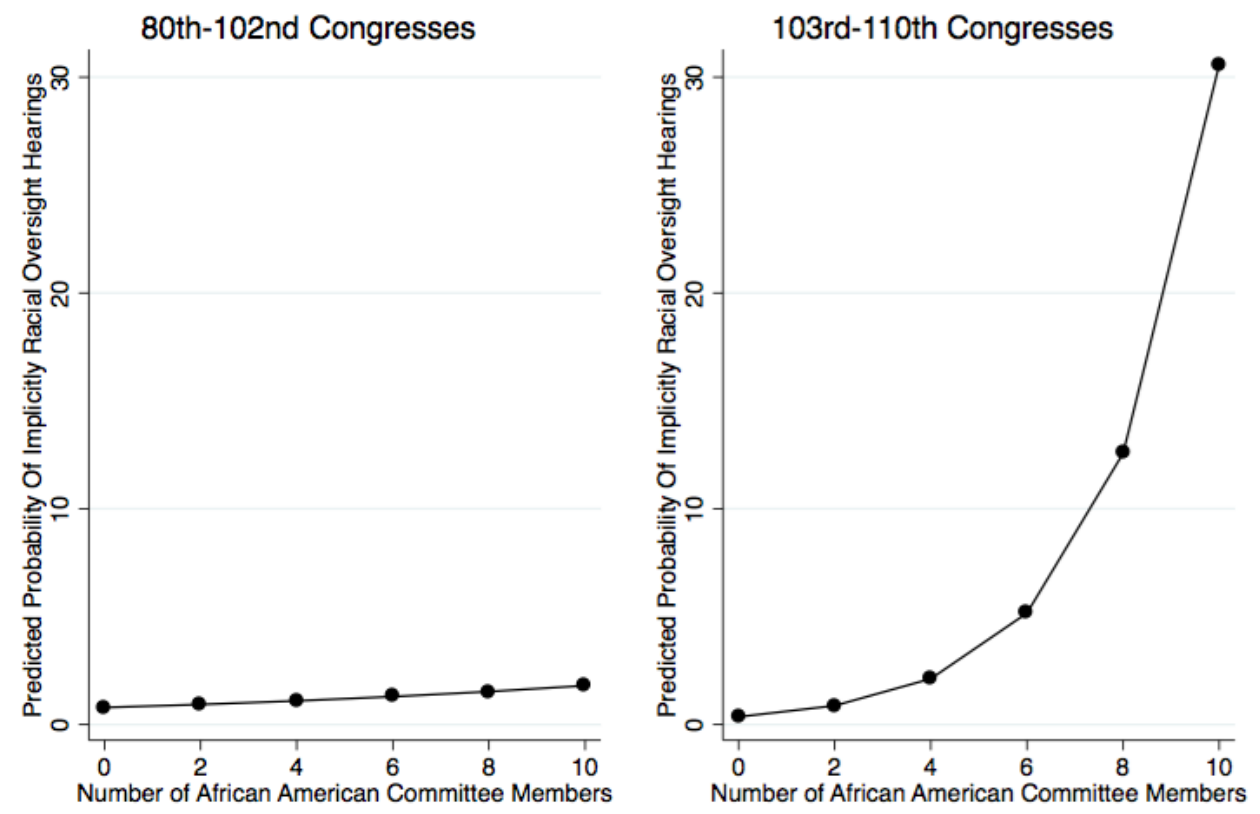
Undoubtedly, however, there are other drivers of committee oversight. Appendix I considers one possible such factor, chamber ideology, and shows that while there is a role for ideology, its inclusion in the model does not change the previous findings. It is important to note that ideology does not go in the negative direction one might expect where it is significant (just as having a Democratic House did not go in the positive direction one might expect in the earlier models). This might be due to other controls, or the lack of coding on hearing topics as opposed to volume — conservatives can engage in racial oversight, too, just in ways liberals might find problematic. Perhaps conservativedominated Houses after redistricting held a lot of implicitly racial oversight to tear down liberal programs, and this just happened to coincide with larger numbers of African Americans on committees. Table 3b, however, shows that the influence of African Americans on committees on the volume of implicitly racial oversight remains even when only Democratic Houses are included in the analysis - the relationship is not just there because only volume, rather than substance, was considered. All this said, committee-level variables need to be considered in future research. Because members aim for committee placements based on the work committees do, other models should isolate the role of committee type, with clustered standard errors, and with committeelevel ideology. 
Table 3a. Democratic Majorities Only: Oversight on Explicitly Racial Issues—Logit Analysis

\begin{tabular}{|c|c|c|c|}
\hline Variables & $\begin{array}{l}\text { Full Model; } 80^{\text {th }}- \\
110^{\text {th }} \text { Congresses }\end{array}$ & $\begin{array}{l}80^{\text {th }}-102^{\text {nd }} \text { Congress } \\
\text { Model }\end{array}$ & $\begin{array}{l}103^{\text {rd }}-110^{\text {th }} \\
\text { Congress } \\
\text { Model }\end{array}$ \\
\hline $\begin{array}{c}\text { \# African } \\
\begin{array}{c}\text { Americans on } \\
\text { Committee }\end{array}\end{array}$ & $\begin{array}{l}0.1787^{\wedge} \\
(0.092)\end{array}$ & $\begin{array}{l}0.2713^{\wedge} \\
(0.139)\end{array}$ & 0.1667 \\
\hline $\begin{array}{c}\text { \# Latinos on } \\
\text { Committee }\end{array}$ & 0.2066 & $0.134)$ \\
\hline $\begin{array}{c}\text { \% Minority } \\
\text { Members in } \\
\text { Congress }\end{array}$ & $(0.133)$ & $(0.169)$ & 0.2131 \\
\hline $\begin{array}{c}\text { African American } \\
\text { Chair }\end{array}$ & 0.0239 & -0.0358 & $0.247)$ \\
\hline Latino Chair & $(0.050)$ & $(0.079)$ & $(0.346)$ \\
\hline Constant & -0.6136 & 0.4924 & 0.6744 \\
& $(0.416)$ & $(0.503)$ & $(0.931)$ \\
\hline $\begin{array}{c}\text { Number of } \\
\text { observations }\end{array}$ & $(0.559)$ & $2.5046^{* * *}$ & -0.0467 \\
\hline Log-Likelihood & $-154.30^{* * *}$ & $-2.92^{* * *}$ & $(1.282)$ \\
\hline
\end{tabular}

Note: The dependent variables are explicit and implicit hearings by committees (unit of analysis is the committee-Congress pair), where $0=$ no hearings and $1=1$ or more hearings. Entries are log odds; standard errors are in parentheses.

$* * *=p<0.001 * *=p<0.01 *=p<0.05^{\wedge}=p<0.054$ 
Table 3b. Democratic Majorities Only: Oversight on Implicitly Racial Issues-Negative Binomial Analysis

\begin{tabular}{|c|c|c|c|}
\hline Variables & $\begin{array}{c}\text { Full Model; } 80^{\text {th }}- \\
110^{\text {th }} \text { Congresses }\end{array}$ & $\begin{array}{l}80^{\text {th }}-102^{\text {nd }} \text { Congress } \\
\text { Model }\end{array}$ & $\begin{array}{l}103^{\text {rd }}-110^{\text {th }} \\
\text { Congress } \\
\text { Model }\end{array}$ \\
\hline $\begin{array}{c}\text { \# African } \\
\begin{array}{c}\text { Cmericans on } \\
\text { Committee }\end{array}\end{array}$ & $\begin{array}{l}0.1345^{\wedge} \\
(0.070)\end{array}$ & $\begin{array}{c}-0.0006 \\
(0.102)\end{array}$ & $\begin{array}{c}0.3964^{* *} \\
(0.118)\end{array}$ \\
\hline $\begin{array}{c}\text { \# Latinos on } \\
\text { Committee }\end{array}$ & -0.0017 & 0.0315 & 0.0703 \\
\hline \% Minority & $(0.125)$ & $(0.159)$ & $(0.209)$ \\
Members in & 0.0472 & 0.0552 & $0.5086^{\wedge \wedge}$ \\
Congress & $(0.034)$ & $(0.044)$ & $(0.279)$ \\
\hline $\begin{array}{c}\text { African American } \\
\text { Chair }\end{array}$ & 0.0617 & 0.2876 & -1.2699 \\
\hline Latino Chair & $1.307)$ & $(0.345)$ & $(0.792)$ \\
\hline Constant & $-0.61^{* *}$ & $1.444^{*}$ & 0.9491 \\
& $(0.507)$ & $(0.595)$ & $-0.905)$ \\
\hline Number of & 538 & $-0.64^{* *}$ & $(4.156)$ \\
\hline observations & & $(0.198)$ & 45 \\
\hline Log-Likelihood & $-632.72^{* * *}$ & 493 & $-80.52^{*}$ \\
\hline
\end{tabular}

Note: The dependent variables are explicit and implicit hearing counts by committees (unit of analysis is the committee-Congress pair). Entries are logs of expected counts; standard errors are in parentheses.

$* * *=p<0.001 * *=p<0.01 *=p<0.05^{\wedge}=p<0.06^{\wedge \wedge}=p<0.07$

Certainly, these findings complicate things for the theory of narrow

representation. The theory appears to hold as described up to the $103^{\text {rd }}$ Congress only.

African American membership on committees did not affect implicitly racial oversight up

to that point. However, with the growth of African American and Latino members in

Congress as a whole after the $103^{\text {rd }}$ Congress, increasing numbers of African Americans

on committees greatly influenced implicitly racial oversight. African American

committee membership has no such striking change in influence on explicitly racial 
oversight after the $103^{\text {rd }}$ Congress, but overall African American and Latino membership in the House does become significant for explicitly racial oversight after redistricting. As Karpowitz, Mendelberg, and Shaker (2012) argue is true for women, institutional context and rules matter for the way African American participation affects outcomes. There is evidence here that the influx of African Americans at the committee level benefitted the volume of committee-level oversight for implicitly racial issues much more than it did for explicitly racial oversight.

\section{DISCUSSION AND CONCLUSION}

The following statements about oversight are bolstered by the findings above: committee membership, not just chairmanship, matters. Committee composition, not just House composition, matters. Whether issues are implicitly or explicitly racial matters. Increased numbers of African Americans on committees and African Americans and Latinos in the House mattered differently after the $103^{\text {rd }}$ Congress, meaning redistricting mattered. At least for oversight, there seems to remain some role for descriptive representation, but its influence and impact varies.

Future research can further isolate the impact of redistricting. First, the influence of redistricting also requires an examination of Senate oversight. Senate redistricting obviously did not occur, and even now the Senate is much more white than the House. As such, an examination of whether or not Senate oversight and its drivers changed before and after the $103^{\text {rd }}$ Congress may provide insight. Second, the approach taken here ought to be taken with subcommittee oversight as well, as a great deal of oversight occurs outside standing committees. Third, I do not consider the effect of committee type. Given legislators deliberately choose committees based on their legislative goals 
(Fenno 1973), it is plain some committees will engage in more racially salient oversight than others, and that prospective committee members know this going in and request certain committee assignments accordingly. Therefore, this is a key factor this analysis ignores. Finally, while this chapter focuses on the volume of explicitly and implicitly racial oversight, content of these hearings should be coded as well, in future projects.

However, this chapter has moved beyond the impact of African Americans and Latinos in the House and serving as chairs for oversight, to consider the impact of committee composition. Increased numbers of African Americans on committees appeared to be advantageous for whether or not committees conducted explicitly racial oversight, particularly up to the $103^{\text {rd }}$ Congress. After the $103^{\text {rd }}$ Congress, increased numbers of African Americans on committees dramatically increased the amount of implicitly racial oversight that committees conducted. There was no concomitant increase in the effect of the numbers of African Americans on committees for the occurrence of explicitly racial oversight, however. African Americans and Latinos working within House leadership structures can make a difference. What that difference looks like will vary over time, and the change may be limited by changing goals of other members, but is still important for racially salient oversight. 


\section{CHAPTER FIVE-CONCLUSION}

This project explored representation from many angles, with the goal of better understanding the dynamics of Black and Latino disadvantage in representation. If representational disadvantage is uneven, worse in some areas than in others, it is important to identify this problem so that it can be better understood and resolved. Is representation "narrow?" Does the government better match Black and Latino interests on explicitly over implicitly racial issues? The findings here suggest the answer to this question is not a simple "yes" or "no," at least not in every possible representational context. However, there are signs that the level of racialization is very important for representation.

Chapter 3 indicated narrowness in legislator voting and sponsorship, and Chapter 4 suggested its possible relevance for committee oversight, especially before the $103^{\text {rd }}$ Congress. Chapter 2 showed government stasis when Blacks and Latinos desired change on implicitly racial issues, and when whites desired change on explicitly racial issues. Stasis in government is no big surprise (e.g., Baumgartner and Jones 1993). However, considering Gilens's (2012) findings for the driving role of high-income opinion for government responsiveness on a wide variety issues, and Griffin and Newman's (2008) findings for the similar role of race for responsiveness on racially salient issues, it is somewhat surprising that neither of these seems to matter when the type of racialized representation is brought into better focus. Moreover, one of the underlying concerns here is that narrowness might help lead to particularly poor representation of low-income Blacks and Latinos, and the opinion research presented here indicates this may be the 
case. Income may matter less as an opinion driver among Latinos and especially Blacks compared to whites, but it still matters.

This project explored opinion by race and income, multiple policy dimensions, and four kinds of representation - aggregate government outputs, legislator voting, legislator sponsorship, and committee oversight. This broadness gives the findings implications in multiple subfields. What follows is a summary of the contributions and limitations of each chapter, and potential next steps. "Narrow representation" is far from settled, but there is ample evidence the question is relevant and worth more exploration.

\section{CHAPTER 2}

Contributions to the Literature-Approach and Findings

In Chapter 2, my approach contributes to the racial and ethnic politics and representation literatures in two main ways. First, I investigated the intersectional contributions of racial identity and income level and their impacts upon opinions on implicitly versus explicitly racial issues. Though opinion differences due to race (e.g. Dawson 1995), race and issue nature (e.g. Bobo and Kluegel 1993; Kinder and Winter 2001; Sanchez 2006; Valentino, Hutchings, and White 2007; White 2007), and income (e.g., Gilens) are well-documented, sample size issues plague attempts to examine Black and Latino opinion at the intersection of income, despite recognition that intersectional identity is important (e.g., Strolovitch 2007).

Second, I examined how well government responds to opinions of Blacks and Latinos at different income levels, as evidenced by its implicitly and explicitly racial outputs. Though Griffin and Newman (2008) studied how well government responds to Blacks and Latinos, they do not differentiate opinion by income, or between different 
types of racially salient issues. Finally, their approach to measuring opinion and responsiveness focuses on desired spending levels in existing policy areas, while I examine opinion and responsiveness on policy action or inaction.

The findings in Chapter 2 contribute to the literature as well, both in terms of opinion and representation. When it comes to opinion, as I argued, racialization of opinion - the opinion differences between African Americans and whites, and Latinos and whites - can be conceived as falling along a continuum, from nonracial to slightly racialized on implicitly racial issues to highly racialized on certain explicitly racial issues. Opinion among Blacks and Latinos, and among whites, is nuanced and varied, even when all issues are arguably racially salient. While generally explicitly racial issues cause the biggest differences, as expected, there are some cases where opinion differences by race on implicitly racial issues are just as large as those on explicitly racial issues. For example, while Latinos and whites see the idea of ending automatic birthright citizenship very differently, they are just as split on keeping or repealing the Affordable Care Act. In addition, the splits between Latinos and whites tend to be different than those among African Americans and whites, with more issues having little to no difference between Latinos and whites than for African Americans compared to whites.

When it comes to income, low-income individuals of any race tended to view implicitly racial issues more similarly than they did explicitly racial issues, which aligns with what a reader of Gilens (2012) would expect, and to be closer to one another on implicitly racial issues than high-income individuals of different races were, which aligns with what a reader of Dawson (1995) would expect. Further, as Dawson (1995) argued, income matters less among African Americans and Latinos than it does among whites. 
For whites, on implicitly racial issues, income causes significant differences in opinion among low-income and high-income individuals on almost every issue examined. For African Americans and Latinos, there are many fewer significant differences by income.

However, and this is important, there actually are significant opinion differences by income among both African Americans and Latinos, and unlike opinions among whites, they are less predictable by level of racial salience. Whites tend to be united in race, over income, on explicitly racial issues, and united by income, over race, on implicitly racial issues. Income differences among African Americans, on the other hand, caused opinion splits on implicitly racial issues like trade policy, health care policy, and tax policy, but also explicitly racial issues like affirmative action and permitting undocumented immigrants in the U.S. to use public schools and emergency rooms. Latinos exhibited still more differences by income compared to African Americans (though still less than whites), on implicitly racial issues (minimum wage, Iraq withdrawal, CAFTA, CHIP, TARP), but also explicitly racial issues (amnesty, border patrols, and permitting police to question anyone they suspect of being in the U.S. illegally).

These findings underline the importance of more in-depth surveys and studies on racial group opinion to better investigate and understand these nuances. Much of what we know about income and its relationship to opinion applies largely to white opinion. For example, when Gilens (2012) finds dramatic difference by income, he finds those differences among whites. With this, and my findings, it follows that when he finds that government responds better to high-income citizens, it means that government responds better to high-income white citizens, not all high-income citizens. 
The lack of significant findings in the representation analysis does not support my theory, but it goes against other findings in the literature. "Narrow representation" expected more similarity between Black and Latino opinion and government outputs on explicitly versus implicitly racial issues. While the representation results in chapter 2 do not conform to the expectations of narrow representation, neither do they conform to the expectations of Gilens (2012) or Griffin and Newman (2008). On racially salient issues, opinions of high-income individuals did not seem to drive government outputs, as they did for many issues examined by Gilens (2012). Further, opinions of Black and Latino individuals did not drive government outputs on any racially salient issues in the dataset, counter to what Griffin and Newman (2008) found. That said, white opinion also did not have a relationship with government outputs. Theories of representation might rightly expect some form of majoritarianism or pluralism, but neither seemed to be on display in these policy areas.

The maintenance of the status quo may be the real story here. While Blacks and Latinos desired change more on implicitly racial issues than whites did, and whites desired change more on explicitly racial issues than Blacks and Latinos did, desires for change were rarely met with action. Congress has not been very active on any issues during the timeline examined here. However, even where desired change did occur, on health care, for example, or TARP, the relationship with racial group preferences or racial group/income preferences was not strong enough to emerge significant. Is representation on racially salient issues due to something else? Is it happenstance?

\section{Limitations/Avenues for Future Research}


The findings in the representation section, in particular, are heavily limited by the timeframe. Opinions are examined only from 2006 (when the CCES dataset became available) through 2012 (to allow time for government response), while responses are examined only from 2006 to 2016. Datasets do not permit an exploration before 2006, but future CCES datasets, as well as others that provide large enough samples by race to examine intersectional identities, can provide material for studying government responsiveness beyond 2016. In addition, and relatedly, the examination of racially salient issues is highly limited, to only 48 total in the dataset. Again, this is unavoidable at this time due to the availability of data, but it means any findings cannot be taken as sweeping or wholly conclusive. A survey with many more racially salient issues over longer periods would be particularly helpful for investigating these questions more thoroughly.

In addition, when examining opinions, this chapter considers only African Americans and Latinos, and only income as a second form of potential opinion difference beyond race. Other racial groups ought to be considered, though examining them is still further limited by the availability of data. Other intersectional identities, however, could be examined with the data used in this chapter. For example, are there differences between African American men and women? High-income and low-income men? How does the level of education among Latinos complicate the influence of income? What about the type of job? Marital status? The same approach used to impute opinion by income and race descended from Gilens (2012) and used here can also be applied to these very interesting questions. Lastly, the chapter focused mainly on congressional behavior. 
Deeper focus on executive branch outputs and court opinions, and qualitative work in the manner of Kingdon (1973) are other promising areas for exploration with this lens.

\section{CHAPTER 3}

Contributions to the Literature-Approach and Findings

Chapter 2 considers aggregate government outputs. Chapter 3 moves on to explore what drives individual legislator behavior on explicitly and implicitly racial issues, considering both roll call voting and sponsorship. In addition, it attempts to apply the debate over the either positive (e.g. Tate 2003; Banducci et al 2004; Grose 2011; Minta and Sinclair Chapman 2013) or "perverse" (e.g. Swain 1995; Lublin 1997; Lublin and Voss 2003) effects of ensured descriptive representation for substantive representation on implicitly and explicitly racial issues.

In the past, in studying this question, scholars have tended to focus on racially salient (e.g., Minta and Sinclair Chapman 2013) or simply liberal-leaning issues as a whole (e.g., Lublin 1997), rather than looking for any differentiation between explicitly and implicitly racial issues. In addition, they have not focused on low-income African Americans and Latinos, though one of Swain's (1995) central concerns is that even African American and Latino members of Congress represent the economically affluent more than the economically disadvantaged. Therefore, broaching these questions in not just one but two ways, roll call voting and sponsorship, constitutes a step forward.

Beyond the question asked in the chapter, the findings also contribute to the literature. I examined the only two implicitly racial issues in the dataset where 1) the majority of low-income African Americans' and Latinos' opinions differed from other majority opinions and 2) Congress took the issue all the way to a vote. Overwhelmingly, 
the explanation for legislator vote was not legislator race, or the number of African Americans and Latinos in a district, or the median income of African Americans and Latinos in a district. Instead, the strongest significant relationships were legislator ideology and party. Democrats and liberals were much more likely to support both lowincome African Americans' and Latinos' views than were Republicans and conservatives. This certainly supports the narrow representation idea that legislator race may not be as meaningful an explanation for behavior on implicitly racial issues.

Interestingly, there was some evidence that the exception to the rule might be conservative/Republican Latinos. Republican Latinos were much more likely to support TARP, a policy favored by low-income Latinos, than white Republicans. Republican Latinos were a tiny subset of the $108^{\text {th }}$ Congress, but as their numbers continue to grow, the possible differential activation of race for conservative members of Congress on implicitly racial issues may be important to look for.

Narrow representation also held in the sponsorship analysis. Party, not legislator race, determined whether members of Congress were differently active in sponsoring Iraq withdrawal legislation, the implicitly racial issue. However, on the explicitly racial issue, immigration, though party still mattered, race played an important role in determining whether members sponsored legislation. Latino Democrats were more active in sponsoring “openness to immigration" legislation than other Democrats, and Latino Republicans were less active in sponsoring "closed to immigration" legislation than white Republicans. Interestingly, though amnesty was favored at much higher rates among African Americans than whites, African American Democrats did not exhibit differently active behavior in sponsorship on "openness to immigration" legislation than white 
Democrats. This set of findings supports the idea that representation may be narrow even among African American and Latino members of Congress, focused on explicitly racial issues that affect their groups, more than explicitly racial issues that affect other groups, and more than implicitly racial issues.

Just as district African American and Latino median income did not seem to impact legislator vote in the first analysis, district median income did not seem to impact legislator sponsorship. In fact, legislators active on both of these issues came from more, not less, affluent districts. While this certainly holds with the idea of narrow representation, and that low-income African Americans and Latinos are particularly disadvantaged, even where representation is intended (e.g., Strolovitch 2007), the explanation for this finding may lie in the symbolic politics literature (e.g., Sears et al 1979).

In total, the findings in this chapter do not mean majority-minority districts or descriptive representation are unimportant for substantive representation. On the contrary, the sponsorship analysis shows that for explicitly racial issues, at least, the race of the member of Congress may be powerful for determining substantive representation. In addition, there is some evidence that conservative Latinos may behave differently than other Republicans, both in how they voted and their lack of behavior in sponsorship of certain legislation, compared to other Republicans. However, there are indications that legislator race matters differently for explicitly and implicitly racial issues, and voting and sponsorship behavior. This suggests scholars are right to hunt for positive impacts of descriptive representation beyond voting (e.g. Grose 2011) but that the natures of potentially substantive issues deserve exploration as well. 


\section{Limitations/Avenues for Future Research}

Chapter 3 has a number of limitations. First, it assumes Black and Latino opinions at the national level hold at the district level. This may or may not be true. Data limitations required this assumption, and it is weak in the ways discussed in chapter 3. However, a dataset that sampled enough Blacks and Latinos at the state and/or district level to impute opinions by race and income would constitute a significant improvement for measuring opinion.

Second, chapter 3 examines only two implicitly racial issues in the voting analysis (and no explicitly racial issues in the voting analysis), and just one implicitly racial and one explicitly racial issue in the sponsorship analysis. Again, this was partly due to data limitations, and partly due to congressional inactivity. Using the CCES was necessary, and on the CCES there were truly only two implicitly racial issues where low-income African American and low-income Latino opinion met a majority threshold where other opinions did not, and where Congress took a vote. Given the uniqueness of these two votes, I believe it is fair to say they may tell us more about representation of low-income Blacks and Latinos than first glance suggests. However, I do not believe that voting "yes" on TARP is the best or only way to support low-income Latinos, or that those two votes tell us everything we need to know about responsiveness to low-income opinion. Also problematically, the CCES did not provide a "don't know" option to respondents on these two roll call vote issues, and thus responses may not tell us much about what lowincome Blacks and Latinos really desired.

Similarly, a complete exploration of descriptive representation's impacts on implicitly and explicitly racial issues would require comparing more than sponsorship 
behavior on Iraq withdrawal and immigration. These were weighty and important issues for the time frame examined, and particularly supported by low-income individuals compared to other issues in the dataset. However, they could not possibly tell us everything we need to know about sponsorship behavior as it applies to racially salient issues.

These limitations, however, also suggest how to move forward. To better investigate the possibility of narrow representation, a survey that permits imputation of Black, Latino, and low-income opinion at the district and state level is required. More votes and more issues need to be examined. Longer term, much of this requires new data, but in the shorter term, sponsorship behavior at least seems rife for more in depth exploration across a number of issues.

\section{CHAPTER 4}

\section{Contributions to the Literature-Approach and Findings}

Chapter 4 moves to another form of representation, committee oversight. The consideration of oversight further extends the work's response to scholars like Grose (2011) who recommend examining more than roll call votes to understand the influence of descriptive representation upon substantive representation. I examine the impact of committee members' race upon committee racially salient oversight. Importantly, this has not been done. Minta and Sinclair-Chapman (2013) consider the influence of overall nonwhite membership in the House. Minta (2011) examined participation frequency of nonwhite committee members and length of nonwhite committee members' comments at hearings, for a sample of hearings during three Congresses. Ellis and Wilson (2013) study the impact of African American and Latino committee chairs upon racially salient 
oversight. The findings for all three of these works suggest a positive relationship between nonwhite members and racially salient oversight. However, they do not consider diversity of committee membership. Given Kastellac's (2013) finding-that African American justice membership on appellate benches influences rulings on affirmative action - it seems plausible that the race of committee members, not just the race of the chair, may be important. Chairs depend upon other members to keep their positions (e.g., Smith and Deering 1984; Rohde 1991; Schickler, McGhee, and Sides 2003). To my knowledge, no other dataset is available that tracks the number of African Americans and Latinos on committees, by committee. My work makes this information available for standing committees from the $80^{\text {th }}$ through $110^{\text {th }}$ Congresses.

In addition, while other scholars consider different types of racial salience (Minta 2011; Ellis and Wilson 2013; Minta and Sinclair Chapman 2013), both implicit and explicit, this potential distinction is not a central focus. Relatedly, while Minta and Sinclair-Chapman (2013) examine the influence of increased House diversity over time, they and the other antecedents to my work do not focus upon changes that may have occurred after the members of the $103^{\text {rd }}$ Congress were sworn in. The $103^{\text {rd }}$ Congress was more diverse than the $102^{\text {nd }}$, thanks to the advent of many more majority-minority districts (e.g., Lublin 1997). My approach also contributes to the literature in these ways.

When it comes to findings in Chapter 4, there is much left to consider. However, it appears committee membership—not just chairmanships or House diversity—impact racially salient oversight. In addition, the advent of majority-minority districts impacted how these factors affected racially salient oversight. Before the $103^{\text {rd }}$ Congress, narrow representation held: increasing African American membership on committees affected 
whether committees engaged in explicitly racial oversight, but not implicitly racial oversight. After the $103^{\text {rd }}$ Congress, however, increased numbers of African Americans on committees greatly increased committees' volume of implicitly racial oversight, and no such increase followed for explicitly racial oversight. The implicit/explicit distinction remains important in the oversight arena, though not exactly as expected.

\section{Limitations/Avenues for Future Research}

Committee composition beyond the $110^{\text {th }}$ Congress must be considered. I relied upon Congressional Research Service and historical reports to note member race, and these concluded at the $110^{\text {th }}$ Congress. While noting member race beyond that information might be more time-consuming, it is certainly needed and doable to examine this question more fully. Another reason investigating beyond the $110^{\text {th }}$ Congress is crucial is because the presence of an African American president might have affected racially salient committee oversight in positive or negative ways (Tesler 2010).

I also considered only full committees, and much oversight is conducted at the subcommittee level. Studying this question beyond full committees would, again, mean a significant amount of work with data to note racial membership by subcommittee, but it is necessary. Similarly, I looked only for the volume of racially salient oversight, not the content of hearings. Diving into the nature of each hearing would, again, take much more work, but Chapter 3's sponsorship analysis shows the importance of considering what kind of racially salient representation is happening, not just whether it occurs at all. This approach might explain the odd finding that the likelihood of racially salient oversight's occurrence and volume tended to decrease when the House was Democratic/liberal. Relatedly, we know members of Congress pursue committee assignments based in part 
on their policy goals (Fenno 1973). Undoubtedly, then, African American and Latino members select committees they believe are likely to pursue racially salient oversight. I do not consider the influence of committee type, but more work to do so is sorely needed.

Finally, to better ascertain the influence of majority-minority districts, diversity in lawmaking bodies, and how both or either may have affected the behavior of mostly white committee chairs, this same approach should be taken with the Senate. If, for example, explicitly racial oversight increased at the committee level past the $102^{\text {nd }}$ Congress in the Senate, it suggests that majority-minority districts were actually not helpful for this type of oversight in the House. Therefore, to better understand the positive negative impacts of majority-minority districts and their application to oversight, the Senate requires examination.

\section{CONCLUSION}

This project considers representational disadvantage through the lenses of implicitly and explicitly racial issues and intersectional identity. In doing so, it improves upon findings in the inequality, racial and ethnic politics, public policy, and representation literatures. I considered the simultaneous influence of intersectional identities such as income and race upon opinion, the levels of racialization for racially salient issues, opinion racialization and its influence upon government outputs, the role of low-income opinion for legislator voting and sponsorship, racialization and oversight, and redistricting and oversight. My findings demonstrate the importance of intersectional identity and racialization for representation and policy outcomes.

Better data is required to cross many hurdles central to a full answer to the question of narrow representation. However, there are several steps possible in the short 
term-imputing opinion by other intersectional identities, considering other racial groups' opinions and how they differ by income (or not), examining more sponsorship on implicitly and explicitly racial issues, and comparing Senate oversight on racially salient issues to House oversight. Longer term, with additional surveys of larger samples of all racial groups, and qualitative work with staff and representatives to understand their perspective on these issues, the research possibilities are even more promising.

Beyond its promise for future research, this project stands on its own as a contribution to multiple literatures. It demonstrates that opinions among our most disadvantaged citizens differ from others' opinions, and provides evidence of reduced government representation on implicitly and explicitly racial issues in multiple contexts. Representational disadvantage is not new, but deriving some of its underlying causes in a systematic way has the potential to bring us to a better understanding of it, and how we can change it. 


\section{$\underline{\text { APPENDIX A }}$}

These policy areas were included as candidates for implicitly racial issues. This section explains why these policy areas are substantively important for Blacks and Latinos and, as such, were included in the dataset.

Gun control-African Americans are at increased risk of gun deaths compared to whites. ${ }^{14}$

Climate change and related bills-Studies show a link between climate change and increased air pollution, which affects respiratory issues like asthma. African Americans have the highest rates of asthma among racial and ethnic groups. ${ }^{15}$

Abortion - Abortion rates are higher among Black and Latino women, so threats to abortion access are potentially substantively important. ${ }^{16}$

Ryan Bill-cuts to Medicare/Medicaid-The Ryan Bill included cuts to Medicare and Medicaid. Medicare is available to all members of the population at age 65 regardless of race; however, as access to insurance and health care generally continues to be reduced for Blacks and Latinos, Medicare is particularly important for nonwhite Americans 65 and older. ${ }^{17}$ As for Medicaid, 1 in 4 minorities use Medicaid, and fewer than 1 in 8 whites do. ${ }^{18}$

Simpson Bowles Budget Plan-cuts to Social Security-The Simpson Bowles budget plan included cuts to Social Security. Although Americans of all races receive Social Security at retirement age, nonwhite retirees are more likely to have Social Security as their only source of retirement income. ${ }^{19}$

\footnotetext{
14 http://www.brookings.edu/blogs/social-mobility-memos/posts/2015/12/15-guns-racedifferent-worlds-reeves; https://www.washingtonpost.com/news/wonk/wp/2014/09/19/the-racial-divide-inamericas-gun-deaths/

15 http://www.cdc.gov/VitalSigns/Asthma/index.html

16 https://www.guttmacher.org/pubs/gpr/11/3/gpr110302.html

$17 \mathrm{http}: / /$ content.healthaffairs.org/content/24/2/365.full

$18 \mathrm{http} / / / \mathrm{khn}$.org/news/minorities-would-be-hard-hit-by-medicaid-cuts-study-warns/

$19 \mathrm{http}$ ://www.aarp.org/work/social-security/info-11-2012/social-security-a-keyretirement-income-source-for-older-minorities-AARP-ppi-econ-sec.html
} 
Birth control insurance exemptions - Black and Latino women lack access to birth control at higher rates than whites. ${ }^{20}$ Therefore, providing exemptions to companies that do not wish to cover birth control can impact Black and Latino women.

ACA, comprehensive health care-The ACA aims to improve access to health insurance. ${ }^{21}$ Attempts to repeal it, then, are potentially substantively important to Blacks and Latinos.

American Recovery and Reinvestment Act-While this legislation attempted to alleviate a variety of economic problems, some provisions were potentially particularly important to Blacks and Latinos These include job training programs and business loans. ${ }^{22}$

Renewal of CHIP - CHIP provides health coverage for more than half of Latino and African American children, compared to one quarter of white children. ${ }^{23}$

Troubled Asset Relief Program/federal assistance for housing crisis/financial reformthe subprime mortgage crisis which triggered TARP had special concern for African Americans and Latinos. Banks may see them as a bad risk, meaning that these individuals are more likely to have high cost loans as their only option. ${ }^{24}$

Privatization of Social Security - privatization of Social Security could be seen as endangering the most important source of income for Black and Latino elderly. ${ }^{25}$

Minimum wage-Blacks and Latinos are overrepresented at lowest wage levels. ${ }^{26}$

Central American Free Trade Agreement-Unions tend to oppose free trade agreements, and Blacks and Latinos are disproportionately represented in unions. ${ }^{27}$

Tax policy - Tax breaks and cuts do not tend to benefit Blacks and Latinos to the degree that they do whites. ${ }^{28}$ However, the two tax cut laws presented here differ dramatically in

\footnotetext{
20 http://www.ncbi.nlm.nih.gov/pmc/articles/PMC2835625/

$21 \mathrm{http}: / /$ ldihealtheconomist.com/he0000107.shtml

$22 \mathrm{http}$ ///www.cbcfinc.org/old-site/images/pdf/CBCF-ARRA_report09-PDF2.pdf

$23 \mathrm{http} / / / \mathrm{kff}$.org/report-section/the-impact-of-the-childrens-health-insurance-programchip-issue-brief/

${ }^{24}$ http://www.citylab.com/housing/2013/08/blacks-really-were-targeted-bogus-loansduring-housing-boom/6559/

25 http://www.aarp.org/work/social-security/info-11-2012/social-security-a-keyretirement-income-source-for-older-minorities-AARP-ppi-econ-sec.html

$26 \mathrm{http} / / / \mathrm{www} . n y t i m e s . c o m / 2014 / 06 / 10 /$ upshot/minimum-wage.html

$27 \mathrm{http} / / / \mathrm{www}$. bls.gov/news.release/union2.nr0.htm; http://www.nytimes.com/2013/09/04/nyregion/new-york-citys-unionized-workers-aremostly-minorities-a-study-shows.html

$28 \mathrm{https} / /$ www.washingtonpost.com/news/monkey-cage/wp/2016/04/18/how-the-u-s-taxsystem-disadvantages-racial-minorities/
} 
that the Tax Hike Prevention Act prevents tax hikes for the very wealthy and the Middle Class Tax Cut Act preserves tax cuts for, obviously, the middle class. These distinctions could cause dramatic differences in opinion, but tax policy is highly relevant.

Iraq withdrawal - Rep. Charles Rangel argued the Iraq War was a "death tax" on African Americans and the poor. Though there is evidence against there being higher proportions of Blacks and Latinos than whites dying in Iraq or serving on the front lines, the raising of this issue and its truth in other wars, such as Vietnam, means this issue may continue to be of importance to Blacks and Latinos. 


\section{APPENDIX B}

The sample of CCES questions included the following questions below (Ansolabehere).

Following Gilens (2012), generally, if policy change occurred within 4 years, outcome $=1$, and if not, outcome $=0$. However, if the question specified a tighter timeline than four years, I noted this, and if the change did not occur within that timeframe, outcome $=0$.

I also adopted Gilens's use of "switcher" variables (quote from Representational Inequality Data Coding sheet available on the Russell Sage Foundation website):

For most survey questions, "support" or "favor" means support for a proposed change in the status quo. For these questions, switcher $=0$. But if the question asks about support (or "favor") for current policy or support for a change that has already occurred, switcher $=1$.

The critical thing is that the survey answer of "favor" or support must mean favor a change if switcher $=0$ and must mean favor the status quo if switcher $=1$.

This coding scheme was helpful for use with questions about policies that had already been passed, and differentiating between not just support and opposition but rather policy change and the status quo.

\section{$\underline{\text { Implicitly racial }}$}

\section{Minimum wage 1:}

"As you may know, the federal minimum wage is currently $\$ 5.15$ an hour. Do you favor or oppose raising the minimum wage to $\$ 7.25$ an hour over the next two years, or not?" (2006)

Respondents indicated whether they favored or opposed raising the minimum wage from $\$ 5.15$ an hour to $\$ 7.25$ an hour, with no timeline indicated (2008).

\section{Minimum wage 2:}

"Congress considered a proposal to increase the federal minimum wage from $\$ 5.15$ to $\$ 6.25$ within the next year and a half. Some politicians argue that the wage should be increased because it hasn't changed since 1997 and many workers still live in poverty. Other politicians argue that raising the wage might force small businesses to cut jobs and would hurt the economy. What do you think? If you were faced with this decision, would you vote for or against increasing the minimum wage?" (2006). 
Government response: The federal minimum wage was increased to $\$ 6.55$ in 2008, and \$7.25 in 2009 ("Minimum Wage," US Department of Labor). This is within the fouryear timespan Gilens uses for both 2006 and 2008; however, in 2006 respondents were asked, first, if they would like an increase to $\$ 7.25$ within the next two years, and then if they would like an increase to $\$ 6.25$ within the next year and a half. These thresholds are not quite met, as the increase to $\$ 6.55$ was within two years (rather than a year and a half), and the increase to $\$ 7.25$ was within three years (rather than two). However, there is no timeline set for the question in 2008, so "responsiveness" equals 1 in that case.

\section{Climate change:}

"From what you know about global climate change or global warming, which one of the following statements comes closest to your opinion? 1) Global climate change has been established as a serious problem, and immediate action is necessary. 2) There is enough evidence that climate change is taking place and some action should be taken. 3) We don't know enough about global climate change, and more research is necessary before we take any actions. 4) Concern about global climate change is unwarranted." (2006, 2010,2012 ) I grouped the first and second options into "favoring" action on climate change and the latter two into "opposing" action on climate change.

Government response: Though Democrats in the $110^{\text {th }}$ Congress attempted to pass "a comprehensive national policy" focused on global warming, the Lieberman-Warner Climate Security Act of 2008, Senate Republicans prevented the legislation from coming up for a vote ("Senate Republicans Sink Climate Bill” 2008).

\section{Partial Birth Abortion:}

"First, we'd like to ask you about a proposal in Congress to ban a type of late-term abortion sometimes called "partial-birth abortion." Some argue that late-term abortion is a barbaric procedure and should be banned. Others argue that late-term abortions are extremely uncommon and used only in exceptional circumstances best determined by a doctor, not the Congress. The proposed legislation could also be the opening to a broader ban on abortion. How about you? If you were faced with this decision, would you vote for or against banning late-term abortion?" (2006)

Government response: The Partial-Birth Abortion Ban Act was passed in 2003 (PartialBirth Abortion Ban Act of 2003), and remains in place. Thus, those who are for the ban were, in fact, in favor of the status quo in 2006. This variable is coded as a "switcher" variable for that reason, with "switcher" equal to 1 , and since "change" would be removing the ban, and the ban is still in place, the responsiveness variable is 0 .

\section{Birth control exemption:}

"Birth control exemption. A bill to let employers and insurers refuse to cover birth control and other health services that violate their religious beliefs." (2012) Support for such policy is coded as 1 .

Government response:

Rule-making undertaken for the Affordable Care Act allows "religious employers" 
exemption from covering contraceptives in their health insurance plans. Other rules exempt for-profits with "religious objections" to contraceptives. The latter rules were created in response to Burwell v. Hobby Lobby Stores, Inc. ("Fact Sheet: Women's Preventive Services Coverage, Non-Profit Religious Organizations, and Closely-Held For-Profit Entities" 2015). As the rules were created from 2012-2015, this is not a switcher variable, and government responsiveness is 1 .

\section{Social Security:}

"A proposal has been made that would allow people to put a portion of their Social Security payroll taxes into personal retirement accounts that would be invested in private stocks and bonds. Do you favor or oppose this idea?" $(2006,2008)$

Government response: President George W. Bush's Social Security privatization plan, and Congress's lack of action on the plan, is well-documented ("Budget Calls for Domestic Increase” 2008; “Bush's Budget: Opening Salvo in Yearlong Struggle Over Spending" 2007; "Politics and Elections: Political Power Shift Dominates 2006" 2006).

\section{Iraq Withdrawal:}

Congress has also debated a proposal that the president begin phased redeployment of U.S. troops from Iraq starting this year and submit to Congress by the end of 2006 a plan with estimated dates for continued phased withdrawal. Some politicians argue that setting out a plan to withdraw would make Iraqis take responsibility for their country and become more independent of the U.S. Others argue that it is too early to start withdrawing and that doing so would make terrorists grow bolder. What do you think? If you were faced with this decision, would you vote for or against a plan to start withdrawing troops this year? (2006).

"Congress considered many important bills over the past two years. For each of the following tell us whether you support or oppose the legislation in principle. Withdraw troops from Iraq within 180 days." (2008).

Government response: Neither of these time-specific thresholds were met; troops were in Iraq as late as December 2011. Though the language of the question in 2006 is a little vague in terms of whether respondents were indicating they were in favor of a plan passed this year that sets a timetable to remove them in the future, or a plan that is passed this year that sets a timetable to remove them this year. Regardless, the plan was not passed that year and the troops were not removed within the year. Neither were troops removed within 180 days of 2008's survey. Given the time-specific nature of these questions, responsiveness is 0 .

For context, President George W. Bush and the Iraqi Prime Minister signed the "Declaration of Principles for a Long-Term Relationship of Cooperation and Friendship Between the Republic of Iraq and the United States of America" in July 2008. This paved the way for the "Strategic Framework Agreement for A Relationship of Friendship and Cooperation Between the United States and the Republic of Iraq" and the "Agreement Between the United States of America and Republic of Iraq on the Withdrawal of United States Forces from Iraq and the Organization of Their Activities 
During Their Temporary Presence in Iraq," which followed in November. Combat forces, according to these agreements, were to be withdrawn by June 30, 2009, and all forces by December 31, 2011 (Karon 2011; U.S. Congressional Research Service 2009). This agreement held.

Though troops have since returned due to the concerns about ISIL, the respondents queried in 2006 and 2008 would not have ben thinking about Iraq in the context of ISIL.

CAFTA:

This year Congress also debated a new free trade agreement that reduces barriers to trade between the U.S. and countries in Central America. Some politicians argue that the agreement allows America to better compete in the global economy and would create more stable democracies in Central America. Other politicians argue that it helps businesses to move jobs abroad where labor is cheaper and does not protect American producers. What do you think? If you were faced with this decision, would you vote for or against the trade agreement? (2006).

Government response: CAFTA passed in 2005, so the respondents here are being asked their opinion one year later ("Central American Trade Accord Just Squeaks Through" 2005). Thus, this is a switcher variable, and taking action would mean overturning the agreement since 2005, which did not occur. Responsiveness, therefore, equals 0.

Children's Health Insurance Program (CHIP):

"Congress considered many important bills over the past two years. For each of the following tell us whether you support or oppose the legislation in principle. Fund a $\$ 20$ billion program to provide health insurance for children in families earning less than $\$ 43,000 . ”(2008)$

"State Children's Health Insurance Program insures children in low income households. Act would renew the program through 2014 and include 4 million additional children." (2010)

Government Response: CHIP was set to expire in 2007. A temporary authorization saved the program through 2009, but did not increase funding or numbers of children assisted by the program. The Children's Health Insurance Program Reauthorization Act finally passed in 2009, expanding funding to $\$ 33$ billion and coverage to 4.1 million children ("The Kaiser Commission on Medicaid and the Uninsured" 2009). Thus, those supporting the expansion in 2008 had their desires met, and responsiveness equals 1 . The 2010 question followed up on support for the specific version of the bill passed in 2009. Since posed in 2010, this is a switcher variable, meaning "action" would be overturning CHIP, which did not occur (and responsiveness there is equal to 0 ).

Federal Assistance for Housing:

"Congress considered many important bills over the past two years. For each of the following tell us whether you support or oppose the legislation in principle. Federal 
assistance for homeowners facing foreclosure and large lending institutions at risk." (2008)

Government response: The Housing and Economic Recovery Act of 2008 gave the government the ability to assist lending institutions (for example, Frannie Mae and Freddie Mac); created the Affordable Housing Fund to help low-income families pursue homeownership; and created a program to assist those struggling to make their mortgage payments, Hope for Homeowners ("Details of Mortgage Finance Bill" 2008). In a follow up, the 2009 Preventing Mortgage Foreclosures and Enhancing Mortgage Credit Act attempted to make the process of refinancing mortgages under the Hope for Homeowners Program created in 2008 easier, as few people by 2009 had taken advantage of the new program ("Mortgage Assistance Bill Signed" 2009).

\section{Bank bailout:}

"Congress considered many important bills over the past two years. For each of the following tell us whether you support or oppose the legislation in principle. U.S.

Government's \$700 Billion bank bailout plan.” (2008)

Interviewers asked specifically whether respondents favored the Troubled Asset Relief Program, or TARP, which provided $\$ 700$ billion to stabilize the financial industry (2010).

Government response: Though the $\$ 700$ billion package in TARP passed in 2008 ("Congress Clears $\$ 700$ Billion Bailout of Financial Services Industry" 2008), the DoddFrank Wall Street Reform and Consumer Protection Act lowered the authorization to just \$475 billion ("Historic Financial Overhaul Creates Bureau, Expands Oversight of Banks" 2010). Later, the Congressional Budget Office estimated the amount spent would actually be $\$ 431$ billion (Congressional Budget Office 2012). For 2008, passing this act represents change, and it was passed. Therefore, "switcher" is equal to 0 , and responsiveness to 1 . By 2010, wanting "change" regarding TARP would mean overturning it, so the 2010 TARP variable is a "switcher" variable. Government responsiveness is 0 , however, because though funding for TARP was reduced, it remained extremely high.

Financial Reform:

"Financial Reform Bill protects consumers against abusive lending. Regulates high risk investments known as derivatives. Allows government to shut down failing financial institutions." (2010)

Government response:

The Dodd-Frank Wall Street Reform and Consumer Protection Act became law in 2010. The law liquidated failing institutions and created a Financial Stability Oversight Council, which can vote to break up companies that threaten the financial system. It also set new standards for home loans ("Historic Financial Overhaul Creates Bureau, Expands Oversight of Banks" 2010).

Comprehensive health care: 
"Do you favor or oppose the U.S. government guaranteeing health insurance for all citizens, even if it means raising taxes?" (2008)

"Comprehensive Health Reform Act requires all Americans to obtain health insurance. Allows people to keep current provider. Sets up health insurance option for those without coverage. Increase taxes on those making more than $\$ 280,000$ a year.” (2010)

"Affordable Care Act of 2010. Requires all Americans to obtain health insurance. Allows people to keep current provider. Sets up health insurance option for those without coverage. Increases taxes on those making more than $\$ 280,000$ a year." (2012)

"Repeal Affordable Care Act. Would repeal the Affordable Care Act.” (2012)

Government response: The Affordable Care Act, passed in 2010, remains in place, despite numerous attempts to repeal or defang it (U.S. Congressional Research Service 2016, "Legislative Actions to Repeal, Defund, or Delay the Affordable Care Act"). The "switcher" variable is equal to 1 only in 2012, because respondents who favored the act by that time were now in favor of the status quo. Responsiveness to a desire for comprehensive health care is equal to 1 in 2008 and 2010. Those in favor of a change in 2012 were against the ACA, so responsiveness there equals 0. For the ACA repeal variable, responsiveness is also 0 , because the ACA has not been overturned.

\section{Carbon tax:}

"What do you think of a fuel tax to reduce greenhouse gas emissions? A gasoline tax of 25 cents per gallon and an electricity tax of $\$ 25$ per month would reduce greenhouse gas emissions by approximately 40 percent over the next 10 years. Would you support or oppose such a tax?” (2008)

Government response: Despite some efforts ("Options and Considerations for a Federal Carbon Tax" 2013), nothing has changed on the carbon tax front for many years (Gale 2016). The current gas tax remains at 18.4 cents per gallon (Plumer 2013).

American Clean Energy and Security Act:

"American Clean Energy and Security Act imposes a cap on carbon emissions and allows companies to trade allowances for carbon emissions. Funds research on renewable energy." (2010)

Government response: The American Clean Energy and Security Act, with its cap and trade system for reducing emissions (U.S. Environmental Protection Agency Office of Atmospheric Programs 2009) passed the House in 2009 but did not survive the Senate. Proposed in 2014, the Clean Power Plan, to be undertaken by the EPA (U.S. Environmental Protection Agency 2016) under the authority of the Clean Air Act (U.S. Environmental Protection Agency 2015) has elements of the cap and trade system (Oremus 2015). However, it is currently halted in its implementation, awaiting judicial review (U.S. Environmental Protection Agency 2016). Therefore, responsiveness equals 0 . 
Gun control

"In general, do you feel that the laws covering the esale of firearms should be made more strict, less strict, or kept as they are?" $(2010,2012)$ I dealt only with those who felt the laws should be more strict, placing those who wanted "less strict" laws and those who wanted laws "kept the same" in the same "0" category.

Government response: Gun control efforts undertaken in Congress after the Sandy Hook shooting were unsuccessful (Liebelson 2013). Though President Obama's executive plan, announced in 2016, aims to remove background check loopholes, hire additional FBI examiners to complete background checks, and research "smart gun" technology (Lederman 2016) it is unclear yet what the impact of these ideas will be on the sale of firearms, though it's predicted to be "relatively small" (Lederman 2016 (2)). Responsiveness, therefore, equals 0.

American Recovery and Reinvestment Act

"American Recovery and Reinvestment Act. Authorizes $\$ 787$ billion in federal spending to stimulate economic growth in the U.S." (2010)

Government response: The American Recovery and Reinvestment Act became law in 2009. As this question was posed in 2010, those who favored change on this are against the American Recovery and Reinvestment Act, making it a "switcher" variable. The American Recovery and Reinvestment Act survived, so response to a desired change to this policy from 2010 forward is 0 .

\section{Ryan Bill}

2011 House Budget Plan. The Budget plan would cut Medicare and Medicaid by $42 \%$. Would reduce debt by $16 \%$ by $2020 . "$ (2012)

Government response: Though Ryan's plan made it through the House ("House Adopts GOP Budget Plan” 2011), that's as far as it got.

\section{Simpson-Bowles Budget Plan}

"Simpson-Bowles Budget Plan. Plan would make 15\% cuts across the board in Social Security, Medicare, Medicaid, and Defense, as well as other programs. Eliminate many tax breaks for individuals and corporations. Would reduce debt by 215 by 2020." (2012)

Government response: This plan, the brainchild of President Obama's executive-ordered (Executive Order 13531) bipartisan debt commission, did not make headway in Congress ("Debt Plan Fails to Reach Hill" 2010).

Middle Class Tax Cut

The Middle Class Tax Cut Act would extend Bush era tax cuts for incomes below $\$ 200,000$. Would increase the budget deficit by an estimated $\$ 250$ billion." (2012) 
Government Response: Though the original Middle Class Tax Cut Act did not survive the House, in 2013, the American Taxpayer Relief Act passed, and preserved the Bushera tax cuts for those individuals with incomes below \$400,000 (Klein 2013).

\section{Tax Hike Prevention Act}

"The Tax Hike Prevention Act. Would extend Bush-era tax cuts for all individuals, regardless of income. Would increase the budget deficit by an estimated \$405 billion." (2012)

Government Response: As noted above, the American Taxpayer Relief Act ended the Bush-era tax cuts for those making more than $\$ 400,000$ (Klein 2013). Therefore, responsiveness equals 0 .

\section{$\underline{\text { Explicitly racial }}$}

\section{Affirmative Action:}

"Some people think that if a company has a history of discriminating against blacks when making hiring decisions, then they should be required to have an affirmative action program that gives blacks preference in hiring. What do you think? Should companies that have discriminated against blacks have to have an affirmative action program?" (2006).

"Affirmative action programs give preference to racial minorities and to women in employment and college admissions in order to correct for past discrimination. Do you support or oppose affirmative action?" $(2008,2010,2012)$

Government response:

The status quo is that affirmative action still exists. The Supreme Court has tinkered with it from time to time, but in its latest session reaffirmed its use (Fisher v. University of Texas). Congress has been content to leave the issue alone since the mid-1990s ("Affirmative Action" 2015), but given its continued controversial nature, that alone is significant. Responsiveness to change in this area is equal to 0.

\section{Immigration:}

"Another issue is illegal immigration. One plan considered by the Senate would offer illegal immigrants who already live in the U.S. more opportunities to become legal citizens. Some politicians argue that people who have worked hard in jobs that the economy depends on should be offered the chance to live here legally. Other politicians argue that the plan is an amnesty that rewards people who have broken the law. What do you think? If you were faced with this decision, would you vote for or against this proposal?" (2006)

Respondents indicated their support or opposition for the following: -Fining businesses that hire illegal immigrants $(2010,2012)$ 
-Granting legal status to illegal immigrants who have paid taxes and held jobs for three years and who have no felony convictions $(2010,2012)$

-Increasing border patrols on the U.S.-Mexico border (2010, 2012)

-Allowing the police to question anyone they suspect may be in the U.S. illegally (2010, 2012)

-Prohibiting illegal immigrants from using emergency care and public schools (2012)

-Denying citizenship to American-born children of illegal immigrants (2012).

Government response:

The Senate passed immigration reform in 2013 (Kim 2013), but it stalled after that. The bill dealt with many of the issues CCES respondents were queried about, including providing a "pathway to citizenship," a "workplace verification system for employers," increased border security, and a new visa program (Kim 2013). Similarly, versions of the DREAM Act, which would provide citizenship to undocumented immigrants who arrived in the U.S. as children and went to school here, provided they met certain qualifications (The DREAM Act"), were debated in both the House and the Senate but have not been successful. President Obama utilized executive orders to create Deferred Action for Childhood Arrivals, or DACA, which would defer deportation for families of U.S. citizens, provided they had committed no felonies, can pass a background check, and pay taxes. However, progress on this front is stalled, as the action is under injunction (United States Citizenship and Immigration Services), and the Supreme Court tied on the issue this term (United States v. Texas). Responsiveness to the amnesty and "granting citizenship" questions is thus equal to 0 .

In addition, here are efforts on issues raised in specific questions:

Border patrol levels and funding have steadily increased (U.S. Congressional Research Service 2016). Responsiveness to this desire equals 1.

There are fines for businesses who knowingly hire illegal immigrants (Meyers 2016), but not much has changed on this front since 1986 ("Employer Sanctions" 2016). Therefore, this is a switcher variable, where change would indicate ending this policy, and responsiveness is 0 .

Arizona famously passed SB 1070 in 2010, which permitted police to check individuals' immigration status if they suspected individuals they stopped or arrested were in the U.S. illegally. Other states created similar laws, though the federal government did not, and in fact the Obama administration sued Arizona as a result of SB 1070, stating that the law preempted federal laws on the issue. In Arizona v. U.S. (2012), the Supreme Court struck down much of SB 1070 but retained the "reasonable suspicion" component. However, they suggested that further legal challenges regarding the clause may occur (Winograd 2012). Responsiveness as of 2016 equals 1 . 
Undocumented immigrants may receive emergency care (Gusmano 2012), and undocumented children can attend K-12 Public Schools (Olivas 2010; Plyler v. Doe 1982). Responsiveness to changing this status quo is 0 .

The current interpretation of the $14^{\text {th }}$ Amendment is that it guarantees birthright citizenship, though this interpretation continues to be hotly debated (Peralta 2015). Responsiveness to changing this interpretation equals 0.

\section{Appendix C:}

\section{Differences in Median Opinion between Groups by Income Level}

\begin{tabular}{lccc}
\hline & $\begin{array}{l}\text { Implicitly Racial } \\
\text { Issues }\end{array}$ & $\begin{array}{l}\text { Explicitly Racial } \\
\text { Issues } \\
\text { (Affirmative } \\
\text { Action) }\end{array}$ & $\begin{array}{l}\text { Explicitly Racial } \\
\text { Issues } \\
\text { (Immigration) }\end{array}$ \\
\hline $\begin{array}{l}\text { Low-Income African Americans } \\
\text { and Low-Income Whites }\end{array}$ & 1 & 7 & 3 \\
$\begin{array}{l}\text { High-Income African } \\
\text { Americans and High-Income }\end{array}$ & 3 & 8 & 3 \\
$\begin{array}{l}\text { Whites } \\
\text { Low-Income Latinos and Low- } \\
\text { Income Whites }\end{array}$ & 1 & 5.5 & 5 \\
$\begin{array}{l}\text { High-Income Latinos and High- } \\
\text { Income Whites }\end{array}$ & 2 & 3.5 & 3
\end{tabular}


Appendix D: White Opinion by Income

\begin{tabular}{|c|c|c|c|c|}
\hline \multirow{2}{*}{ Year } & \multirow{2}{*}{ Policy } & \multicolumn{2}{|c|}{ Income Percentile } & \multirow{2}{*}{$\begin{array}{c}\text { Difference } \\
\text { Highest- } \\
\text { Lowest }\end{array}$} \\
\hline & & Lowest & Highest & \\
\hline 2006 & Minimum Wage1*** & 4 & 2 & 2 \\
\hline 2008 & Minimum Wage*** & 5 & 3 & 2 \\
\hline 2006 & Minimum Wage $2 * * *$ & 5 & 3 & 2 \\
\hline 2006 & Climate Change*** & 3 & 1 & 2 \\
\hline 2010 & Climate Change*** & 1 & 0 & 1 \\
\hline 2012 & Climate change*** & 2 & 1 & 1 \\
\hline 2006 & PartialBirth*** & 1 & 1 & 0 \\
\hline 2012 & BirthControlEx*** & -3 & -1 & 2 \\
\hline 2006 & Social Security*** & -1 & 2 & 3 \\
\hline 2008 & Social Security*** & 0 & 1 & 1 \\
\hline 2006 & Iraq*** & 3 & 0 & 3 \\
\hline 2008 & $\operatorname{Iraq} * * *$ & 3 & -1 & 4 \\
\hline 2006 & CAFTA*** & -3 & 0 & 3 \\
\hline 2008 & CHIP*** & 5 & 1 & 4 \\
\hline 2010 & CHIP*** & 4 & 2 & 2 \\
\hline 2008 & Housing*** & 2 & -2 & 4 \\
\hline 2010 & BankBail** & -4 & -3 & 1 \\
\hline 2010 & TARP* & -3 & -3 & 0 \\
\hline 2010 & Financial Reform*** & 3 & 1 & 2 \\
\hline 2008 & $\begin{array}{l}\text { Comprehensive } \\
\text { Healthcare**** }\end{array}$ & 3 & 0 & 3 \\
\hline 2010 & $\begin{array}{l}\text { Comprehensive } \\
\text { Healthcare*** }\end{array}$ & 0 & -1 & 1 \\
\hline 2012 & $\mathrm{ACA} * * *$ & 1 & 0 & 1 \\
\hline 2012 & ACARepeal*** & -1 & 0 & 1 \\
\hline 2008 & CarbonTax*** & -4 & -3 & 1 \\
\hline
\end{tabular}




\begin{tabular}{|c|l|c|c|c|}
\hline 2010 & ACESA*** & 2 & 0 & 2 \\
\hline 2010 & Gun Control*** & 1 & 2 & 1 \\
\hline 2012 & Gun Control*** & 1 & 2 & 1 \\
\hline 2010 & ARRA*** & 0 & -1 & 1 \\
\hline 2012 & RyanBill*** & -5 & -3 & 2 \\
\hline 2012 & SimpBowles*** & -2 & 1 & 3 \\
\hline 2012 & MidTax*** & 1 & 2 & 1 \\
\hline 2012 & TaxHike & -4 & -3 & 1 \\
\hline 2006 & AffrmAct*** & -3 & -4 & 1 \\
\hline 2008 & AffrmAct*** & -1 & -3 & 2 \\
\hline 2010 & AffrmAct*** & -3 & -3 & 0 \\
\hline 2012 & AffrmAct*** & -3 & -3 & 0 \\
\hline 2006 & Immigration $* * *$ & -2 & -2 & 0 \\
\hline 2010 & FineBusinesses & 3 & 4 & 1 \\
\hline 2012 & FineBusinesses*** & 2 & 3 & 1 \\
\hline 2010 & GrantStatus*** & -2 & -2 & 0 \\
\hline 2012 & GrantStatus*** & -1 & 0 & 1 \\
\hline 2010 & BorderPatrols*** & 2 & 2 & 0 \\
\hline 2012 & BorderPatrols*** & 1 & 1 & 0 \\
\hline 2010 & PoliceQuestion*** & -1 & -3 & 0 \\
\hline 2012 & PoliceQuestion*** & -2 & -1 & 0 \\
\hline 2012 & ER/Schools*** & & & 0 \\
\hline 2012 & AutoCitizenship*** & -3 & 1 \\
\hline & & -3 & \\
\hline
\end{tabular}

Note:

Table shows differences in opinion among whites, using coding levels for imputed preferences devised by Gilens.:

Between $45 \%$ and $55 \%=0$

Over $55 \%$ or under $45 \%=+1 /-1$

Over $60 \%$ or under $40 \%=+/-2$

Over $65 \%$ or under $35 \%=+/-3$

Over $75 \%$ or under $25 \%=+/-4$

Over $85 \%$ or under $15 \%=+/-5$

P-values indicate where differences in opinion among whites, by income, are significant in logit regressions, where the dependent variable is support or opposition for a policy among whites, and income levels among whites are the predictors.

$* * *=\mathrm{p}<0.001$

$* *=\mathrm{p}<0.01$

$*=\mathrm{p}<0.05$ 


\section{$\underline{\text { APPENDIX E }}$}

Bills included in sponsorship analysis, divided by section.

Iraq

-To provide for the withdrawal of United States Armed Forces from Iraq, to authorize assistance for Iraq, and for other purposes.

-To provide for a timetable for the redeployment of the United States Armed Forces from Iraq and to seek political and diplomatic solutions for the security and stability of the Republic of Iraq.

-To require United States military disengagement from Iraq, to provide United States assistance for reconstruction and reconciliation in Iraq, and for other purposes.

-To limit the length of deployment of members of the Armed Forces for Operation Iraqi Freedom.

-To limit the use of funds to establish any military installation or base for the purpose of providing for the permanent stationing of United States Armed Forces in Iraq or to exercise United States economic control of the oil resources of Iraq.

-To limit the use of funds to establish any military installation or base for the purpose of providing for the permanent stationing of United States Armed Forces in Iraq or to exercise United States economic control of the oil resources of Iraq.

-To redeploy United States Armed Forces from the non-Kurdish areas of Iraq if certain security, political, and economic benchmarks relating to Iraq are not met, and for other purposes. 
-To safely redeploy United States troops from Iraq.

-To repeal the Authorization for Use of Military Force Against Iraq Resolution of 2002 (Public Law 107-243).

-To provide for the redeployment of United States Armed Forces and defense contractors from Iraq.

-To repeal the Authorization for Use of Military Force Against Iraq Resolution of 2002

(Public Law 107-243) and to require the withdrawal of United States Armed Forces from Iraq.

-To redeploy United States Armed Forces from Iraq and to establish a new direction for United States policy toward Iraq.

-To set forth limitations on the United States military presence in Iraq and on United States aid to Iraq for security and reconstruction, and for other purposes.

-To require the President to develop a plan containing dates certain for the commencement and completion of a phased redeployment of United States Armed Forces from Iraq, and for other purposes.

-To end the United States occupation of Iraq immediately.

-To enhance the national security interests of the United States both at home and abroad by setting a deliberate timetable for the redeployment of United States Armed Forces from Iraq by December 31, 2007, and for other purposes.

-To establish a sunset for the Authorization for Use of Military Force Against Iraq Resolution of 2002 (Public Law 107-243).

-To prohibit the use of funds for an escalation of United States forces in Iraq above the numbers existing as of January 9, 2007. 
-To mandate minimum periods of rest and recuperation for units and members of the regular and reserve components of the Armed Forces between deployments for Operation Iraqi Freedom or Operation Enduring Freedom.

-A bill to terminate the authority of the President to waive, with regard to Iraq, certain provisions under the National Defense Authorization Act for Fiscal Year 2008 unless certain conditions are met.

- To ensure that any agreement with Iraq containing a security commitment or arrangement is concluded as a treaty or is approved by Congress.

- A bill to require the Secretary of Defense to submit to Congress reports on the status of planning for the redeployment of the Armed Forces from Iraq and to require the Secretary of Defense, the Chairman of the Joint Chiefs of Staff, and appropriate senior officials of the Department of Defense to meet with Congress to brief Congress on the matters contained in the reports.

- To require the safe, complete, and fully-funded redeployment of United States Armed Forces and contractor security forces from Iraq and to prohibit the establishment of any enduring or permanent United States military bases in Iraq, and for other purposes. - To provide for the protection of members of the United States Armed Forces and for their withdrawal from Iraq by December 31, 2007.

- To require the immediate redeployment of United States Armed Forces from Iraq.

- To amend the reporting requirements in the Department of Defense Appropriations Act, 2007 relating to military and political stability in Iraq to require additional information on the number of combatants and non-combatants killed, and for other purposes. 
- To repeal the Authorization for Use of Military Force Against Iraq Resolution of 2002 (Public Law 107-243) and to require the withdrawal of the United States Armed Forces in Iraq.

- To reassert the constitutional role of Congress in making long-term security commitments, to defer significant long-term security commitments to Iraq to the next Administration and Congress, and to maintain international legal authority and immunity for United States Armed Forces in Iraq by promoting the extension of the United Nations mandate.

- To require the Secretary of Defense to commence the reduction of the number of United States Armed Forces in Iraq to a limited presence by April 1, 2008, and for other purposes.

- To provide for the safe and orderly withdrawal of United States military forces and Department of Defense contractors from Iraq, and for other purposes.

- To prohibit an escalation in the number of members of the United States Armed Forces deployed in Iraq.

-To provide for the redeployment of United States Armed Forces and defense contractors from Iraq.

- To repeal the Authorization for Use of Military Force Against Iraq Resolution of 2002 (Public Law 107-243), and for other purposes.

- Expressing the sense of Congress that Iraq should vote to approve or disapprove the continued deployment of United States Armed Forces to Iraq and, unless Iraq votes to approve such continued deployment, the President of the United States should commence 
the phased redeployment of United States Armed Forces from Iraq within 60 days of the Iraqi vote.

- Disagreeing with the plan announced by the President on January 10, 2007, to increase by more than 20,000 the number of United States combat troops in Iraq, and urging the President instead to consider options and alternatives for achieving success in Iraq. - Urging the United States Government to initiate a diplomatic surge to foster security and stability in the Middle East by engaging international stakeholders and governments throughout the region to curtail destabilizing influences, help prevent the spread of violence, address humanitarian concerns, and enhance prospects for security, political, and economic progress in Iraq.

- Expressing the need for a more comprehensive diplomatic initiative led by the United States, Republic of Iraq, and international community.

- Expressing the sense of Congress that the Government of Iraq should schedule a referendum to determine whether or not the people of Iraq want the Armed Forces of the United States to be withdrawn from Iraq or to remain in Iraq until order is restored to the country.

- Declaring that it is the policy of the United States not to establish any military installation or base for the purpose of providing for the permanent stationing of United States Armed Forces in Iraq and not to exercise United States control of the oil resources of Iraq.

- Expressing the sense of Congress that the Government of Iraq should schedule a referendum to determine whether or not the people of Iraq want the Armed Forces of the 
United States to be withdrawn from Iraq or to remain in Iraq until order is restored to the country.

- Disapproving of the decision of the President announced on January 10, 2007, to deploy more than 20,000 additional United States combat troops to Iraq.

- Recognizing March 19, 2008, as the fifth anniversary of the Iraq war and urging President George W. Bush to begin an immediate and safe redeployment of United States Armed Forces from Iraq.

- Expressing the sense of Congress that the Government of the United States should submit to the Government of Iraq a draft bilateral status-of-forces agreement by not later than September 1, 2007.

- Expressing the sense of Congress that the President should not order an escalation in the total number of members of the United States Armed Forces serving in Iraq.

- To redeploy U.S. forces from Iraq.

- Expressing the sense of the House of Representatives that an increase in number of members of the United States Forces deployed in Iraq is the wrong course of action and that a drastic shift in the political and diplomatic strategy of the United States is needed to help secure and stabilize Iraq.

- Expressing the sense of the House that the United States should increase United States forces in Afghanistan and responsibly redeploy forces from Iraq.

- Providing for consideration of the concurrent resolution (H. Con. Res. 63) disapproving of the decision of the President announced on January 10, 2007, to deploy more than 20,000 additional United States combat troops to Iraq. 
- Providing for consideration of the bill (H.R. 2956) to require the Secretary of Defense to commence the reduction of the number of United States Armed Forces in Iraq to a limited presence by April 1, 2008, and for other purposes.

- Calling on the President of the United States not to commit the United States to any status of forces agreement or any other bilateral agreement with the Republic of Iraq that involves the continued presence of the United States Armed Forces in Iraq unless the agreement includes a provision under which the Republic of Iraq agrees to reimburse the United States for all costs incurred by the United States related to the presence of United States Armed Forces in Iraq after the effective date of the agreement.

- Expressing the sense of the House of Representatives that the United States should accept the Iraqi Governments stated goal of setting a timetable for withdrawal of United States Armed Forces from Iraq.

- Providing for consideration of the bill (H.R. 2237) to provide for the redeployment of United States Armed Forces and defense contractors from Iraq, providing for consideration of the bill (H.R. 2206) making emergency supplemental appropriations for the fiscal year ending September 30, 2007, and for other purposes, and providing for consideration of the bill (H.R. 2207) making supplemental appropriations for agricultural and other emergency assistance for the fiscal year ending September 30, 2007, and for other purposes.

- Providing for consideration of the bill (H.R. 3159) to mandate minimum periods of rest and recuperation for units and members of the regular and reserve components of the Armed Forces between deployments for Operation Iraqi Freedom or Operation Enduring Freedom. 
- To prohibit the use of funds to maintain United States Armed Forces and military contractors in Iraq after December 31, 2011, and for other purposes.

- Expressing the sense of the House of Representatives that the United States should leave no member of the Armed Forces unaccounted for in the withdrawal of forces from Iraq and Afghanistan.

\section{Openness to immigration}

-To authorize any alien who has been issued a valid machine-readable biometric border crossing identification card to be temporarily admitted into the United States upon successfully completing a background check.

- To amend the Immigration and Nationality Act to permit the admission to the United States of nonimmigrant students and visitors who are the spouses and children of United States permanent resident aliens, and for other purposes.

- To provide discretionary authority to an immigration judge to determine that an alien parent of a United States citizen child should not be ordered removed from the United States.

-To establish the Comprehensive Immigration Reform Commission.

-To amend the Immigration and Nationality Act with respect to temporary admission of nonimmigrant aliens to the United States for the purpose of receiving medical treatment, and for other purposes.

-To provide for comprehensive immigration reform, and for other purposes.

-To provide discretionary authority to an immigration judge to determine that an alien parent of a United States citizen child should not be ordered removed, deported, or excluded from the United States. 
-To amend the Illegal Immigration Reform and Immigrant Responsibility Act of 1996 to permit States to determine State residency for higher education purposes and to authorize the cancellation of removal and adjustment of status of certain alien students who are long-term United States residents and who entered the United States as children, and for other purposes.

-To exempt from numerical limitations any alien who has received a Ph.D. from an institution of higher education within the 3-year period preceding such aliens petition for special immigrant status.

- To amend part E of title IV of the Social Security Act to require States to help alien children in the child welfare system apply for all available forms of immigration relief, and for other purposes.

-To provide the nonimmigrant spouses and children of nonimmigrant aliens who perished in the September 11 terrorist attacks an opportunity to adjust their status to that of an alien lawfully admitted for permanent residence, and for other purposes.

-To amend the Medicare Prescription Drug, Improvement, and Modernization Act of 2003 to extend Federal reimbursement of emergency health services furnished to undocumented aliens, and for other purposes.

- To authorize Federal payment to emergency ambulance and medical services providers for the cost of uncompensated care of aliens aided by the border patrol or other Federal immigration officials.

-Disapproving the rule submitted to the Congress by U.S. Citizenship and Immigration Services requiring certain lawful permanent residents to apply for a new Permanent Resident Card. 
- To amend the Immigration and Nationality Act to provide authority for immigration judges to terminate proceedings or appoint counsel when necessary for aliens with mental disabilities, and for other purposes.

-To authorize the cancellation of removal and adjustment of status of certain alien students who are long-term United States residents and who entered the United States as children, and for other purposes.

-To provide for enhanced protections for vulnerable unaccompanied alien children and female detainees.

-To authorize the cancellation of removal and adjustment of status of certain aliens who are long-term United States residents and who entered the United States as children, and for other purposes.

- To amend part E of title IV of the Social Security Act to require States to help alien children in the child welfare system apply for all available forms of immigration relief, and for other purposes.

-To provide the spouses and children of aliens who perished in the September 11 terrorist attacks an opportunity to adjust their status to that of an alien lawfully admitted for permanent residence.

-To amend the Immigration and Nationality Act to provide for nonimmigrant status for an alien who is the parent or legal guardian of a United States citizen child if the child was born abroad and is the child of a deceased member of the Armed Forces of the United States. 
-To provide discretionary authority to an immigration judge to determine that an alien parent of a United States citizen child should not be ordered removed, deported, or excluded from the United States.

-To amend section 1011 of the Medicare Prescription Drug, Improvement, and Modernization Act of 2003 (Public Law 108-173) to make permanent the program of Federal reimbursement of emergency health services furnished to undocumented aliens. -To permit aliens who lawfully enter the United States on valid visas as nonimmigrant elementary and secondary school students to attend public schools in the United States for longer than 1 year if such aliens reimburse the local educational agency that administers the school for the full, unsubsidized per capita cost of providing education at such school for the period of the aliens attendance.

-To amend section 402(a)(2)(M) of the Personal Responsibility and Work Opportunity Reconciliation Act of 1996 to extend by two years the special rule relating to eligibility for benefits under the supplemental security income program for certain aliens and victims of trafficking.

-To amend the Immigration and Nationality Act with respect to temporary admission of nonimmigrant aliens to the United States for the purpose of receiving medical treatment, and for other purposes.

-To authorize the cancellation of removal and adjustment of status of certain aliens who are long-term United States residents and who entered the United States as children, and for other purposes.

-To assist aliens who have been lawfully admitted in becoming citizens of the United States, and for other purposes. 
-To amend the Immigration and Nationality Act to authorize certain aliens who have earned a Ph.D. degree from a United States institution of higher education in a field of science, technology, engineering, or mathematics to be admitted for permanent residence and to be exempted from the numerical limitations on H-1B nonimmigrants.

-Disapproving the rule submitted to the Congress by U.S. Citizenship and Immigration Services on June 6, 2007, relating to adjustment of the Immigration and Naturalization Benefit Application and Petition Fee Schedule.

-To amend the Immigration and Nationality Act to restore certain provisions relating to the definition of aggravated felony and other provisions as they were before the enactment of the Illegal Immigration Reform and Immigrant Responsibility Act of 1996. -To amend the Immigration and Nationality Act to restore certain provisions relating to the definition of aggravated felony and other provisions as they were before the enactment of the Illegal Immigration Reform and Immigrant Responsibility Act of 1996.

-To amend the Immigration and Nationality Act to waive inadmissibility based on a misrepresentation in the case of an immediate relative of an active duty or reserve member of the Armed Forces and to extend the $\mathrm{V}$ nonimmigrant visa program for spouses and children of such a member.

\section{Closed to immigration}

-To end the cycle of illegal immigration in the United States.

-To require those applying for, and renewing, SCHIP, TAA, and ATAA benefits to present documentation proving both citizenship and identity in order to receive those benefits. 
- To impose a mandatory minimum sentence on a deportable alien who fails to depart or fails to attend a removal proceeding.

-To provide for enhanced Federal, State, and local assistance in the enforcement of the immigration laws, to amend the Immigration and Nationality Act, to authorize appropriations to carry out the State Criminal Alien Assistance Program, and for other purposes.

-To deny certain Federal funds to any institution of higher education that admits as students aliens who are unlawfully present in the United States.

-To amend title XIX of the Social Security Act with respect to meeting the citizenship documentation requirement for children born in the United States.

-To assist the Secretary of Homeland Security in carrying out surveillance activities conducted at or near the international land borders of the United States to prevent illegal immigration, and for other purposes.

-To amend the Immigration and Nationality Act to deny visas and admission to aliens who have been unlawfully present in the United States for more than 6 months. -To strengthen procedures regarding detention and removal of aliens. -To amend the Illegal Immigration Reform and Immigrant Responsibility Act of 1996 to provide for two-layered, 14-foot reinforced fencing along the southwest border, and for other purposes.

-To enhance national security by restricting access of illegal aliens to drivers licenses and State-issued identification documents. 
-To amend section 274 of the Immigration and Nationality Act to increase penalties for unlawfully bringing in and harboring aliens with prior felony convictions under Federal law.

-To amend various laws imposing criminal penalties to double the maximum penalty for illegal aliens who commit those crimes, and for other purposes.

-To amend the Immigration and Nationality Act to include in the definition of the term aggravated felony a criminal violation committed by an alien who unlawfully entered the United States.

-To amend the Immigration and Nationality Act to deny citizenship at birth to children born in the United States of parents who are not citizens or permanent resident aliens. -To suspend certain nonessential visas, in order to provide temporary workload relief critical to the successful reorganization of the immigration and naturalization functions of the Department of Homeland Security, to ensure that the screening and monitoring of arriving immigrants and nonimmigrants, and the deterrence of entry and settlement by illegal or unauthorized aliens, is sufficient to maintain the integrity of the sovereign borders of the United States, and for other purposes.

-To remove the incentives and loopholes that encourage illegal aliens to come to the United States to live and work, provide additional resources to local law enforcement and Federal border and immigration officers, and for other purposes.

-To amend the Immigration and Nationality Act and title 18, United States Code, to combat the crime of alien smuggling and related activities, and for other purposes. 
-To impose a criminal penalty on an alien who fails voluntarily to depart the United States after securing permission to do so, or who unlawfully returns to the United States after voluntarily departing.

-To amend the Illegal Immigration Reform and Immigrant Responsibility Act of 1996 to clarify requirements relating to the construction of a physical fence along the southwest border, and for other purposes.

-To prohibit the Secretary of Homeland Security from paroling into the United States an alien who falls ill while seeking admission at a port of entry or seeks emergency medical assistance by approaching an agent or official of the Department of Homeland Security at or near a border.

-To amend section 276 of the Immigration and Nationality Act to impose mandatory sentencing ranges with respect to aliens who reenter the United States after having been removed, and for other purposes.

-To authorize appropriations for the Coast Guard for fiscal year 2008, to amend the Immigration and Nationality Act and title 18, United States Code, to combat the crime of alien smuggling and related activities, and for other purposes.

-To amend title 18, United States Code, to provide mandatory imprisonment for certain kidnapings by illegal aliens.

-To amend the Immigration and Nationality Act to increase criminal penalties for certain removed aliens who illegally reenter the United States.

-To deter alien smuggling criminal enterprises. 
-To amend title XIX of the Social Security Act to permit States, at their option, to require certain individuals to present satisfactory documentary evidence of proof of citizenship or nationality for purposes of eligibility for Medicaid, and for other purposes.

-Expressing the sense of the Congress that the President should immediately and unequivocally call for the enforcement of existing immigration laws in order to reduce the threat of a terrorist attack and to reduce the massive influx of illegal aliens into the United States.

-Expressing the sense of the Congress that State and local governments should be supported for taking actions to discourage illegal immigration and that legislation should be enacted to ease the burden on State and local governments for taking such actions. -Expressing the sense of the House of Representatives regarding the issuance of State drivers licenses or other government-issued photo identification to illegal aliens. -Expressing the sense of the House of Representatives that the Administration should rigorously enforce the laws of the United States to substantially reduce illegal immigration and greatly improve border security.

-Commending Federal and local law enforcement for their efforts to crack down on illegal immigration in the Chicagoland suburbs and calling on the Governor of the State of Illinois to immediately implement employee verification technology to curb rising trends in illegal immigration in the State of Illinois.

-To deny certain Federal funds to any institution of higher education that admits as students aliens who are unlawfully present in the United States. 
-To amend the Internal Revenue Code of 1986 to require certain nonresident aliens to provide valid immigration documents to claim the refundable portion of the child tax credit.

-To provide that States and local governments may pass laws that identify illegal aliens, deter illegal aliens from entering the United States, apprehend illegal aliens, or encourage or otherwise cause illegal aliens to leave the United States, and for other purposes.

-To amend the Illegal Immigration Reform and Immigrant Responsibility Act of 1996 to authorize the Secretary of Homeland Security to construct not less than 350 miles of reinforced fencing along the United States-Mexico border and to gain operational control over such border.

-To provide for enhanced Federal, State, and local assistance in the enforcement of the immigration laws, to amend the Immigration and Nationality Act, to authorize appropriations to carry out the State Criminal Alien Assistance Program, and for other purposes.

-To amend the Immigration and Nationality Act to provide for extensions of detention of certain aliens ordered removed, and for other purposes.

-To amend the Immigration and Nationality Act with respect to detention of unlawfully present aliens who are apprehended for driving while intoxicated, and for other purposes. -To prohibit appropriated funds from being used in contravention of section 642(a) of the Illegal Immigration Reform and Immigrant Responsibility Act of 1996.

-To amend section 276 of the Immigration and Nationality Act to impose mandatory sentencing ranges with respect to aliens who reenter the United States after having been removed, and for other purposes. 
-To amend title I of the Patient Protection and Affordable Care Act to provide for appropriate procedures under such title for verification of citizenship status.

-To provide for expedited removal of certain aliens, and for other purposes.

-Expressing the sense of the Congress that State and local governments should be supported for taking actions to discourage illegal immigration and that legislation should be enacted to ease the burden on State and local governments for taking such actions. -To support the goals and ideals of the National Day of Remembrance of Victims of Illegal Aliens.

-Proposing an amendment to the Constitution of the United States to deny United States citizenship to individuals born in the United States to parents who are neither United States citizens nor persons who owe permanent allegiance to the United States. -To amend section 404 of the Illegal Immigration Reform and Immigrant Responsibility Act of 1996 to allow public institutions of higher education to use the employment eligibility confirmation system established under that section to verify immigration status for purposes of determining eligibility for in-State tuition.

-To provide immigration reform by securing Americas borders, clarifying and enforcing existing laws, and enabling a practical employer verification program.

-To provide immigration reform by securing Americas borders, clarifying and enforcing existing laws, and enabling a practical employer verification program.

-To amend the Immigration and Nationality Act with respect to detention of unlawfully present aliens who are apprehended for driving while intoxicated, to improve State and local enforcement of immigration laws, and for other purposes. 
Not included in these categories: those relating to terrorism, genocide. 


\section{APPENDIX F}

Openness to Immigration Bill Sponsors

\begin{tabular}{|c|c|c|c|c|}
\hline Name & Party & Race & $\begin{array}{l}\text { State, } \\
\text { District }\end{array}$ & Total Sponsored \\
\hline Jeff Flake & $\mathrm{R}$ & White & $\mathrm{AZ}, 6^{\text {th }}$ & 1 \\
\hline Pete Stark & $\mathrm{D}$ & White & $\mathrm{CA}, 13^{\text {th }}$ & 3 \\
\hline Howard Berman & $\mathrm{D}$ & White & $\mathrm{CA}, 28^{\text {th }}$ & 2 \\
\hline $\begin{array}{l}\text { Lucille Roybal- } \\
\text { Allard }\end{array}$ & $\mathrm{D}$ & Latina & $\mathrm{CA}, 34^{\text {th }}$ & 1 \\
\hline Darrell Issa & $\mathrm{R}$ & White & $\mathrm{CA}, 49^{\text {th }}$ & 1 \\
\hline Bob Filner & $\mathrm{D}$ & White & $\mathrm{CA}, 51^{\mathrm{st}}$ & 4 \\
\hline David Rivera & $\mathrm{R}$ & Latino & $\mathrm{FL}, 25^{\text {th }}$ & 2 \\
\hline Carolyn Maloney & $\mathrm{D}$ & White & $\mathrm{NY}, 14^{\text {th }}$ & 2 \\
\hline Jose Serrano & $\mathrm{D}$ & Latino & $\mathrm{NY}, 16^{\text {th }}$ & 3 \\
\hline William Owens & $\mathrm{D}$ & White & $\mathrm{NY}, 23^{\mathrm{rd}}$ & 1 \\
\hline Steve Cohen & $\mathrm{D}$ & White & $\mathrm{TN}, 9^{\text {th }}$ & 2 \\
\hline Jim McDermott & $\mathrm{D}$ & White & $\mathrm{WA}, 7^{\text {th }}$ & 1 \\
\hline $\begin{array}{l}\text { Gabrielle } \\
\text { Giffords }\end{array}$ & $\mathrm{D}$ & White & $\mathrm{AZ}, 8^{\text {th }}$ & 1 \\
\hline Zoe Lofgren & $\mathrm{D}$ & White & $\mathrm{CA}, 16^{\text {th }}$ & 1 \\
\hline Joe Baca & $\mathrm{D}$ & Latino & $\mathrm{CA}, 43^{\text {rd }}$ & 1 \\
\hline Luis Gutierrez & $\mathrm{D}$ & Latino & $\mathrm{IL}, 4^{\text {th }}$ & 2 \\
\hline Frank Pallone & $\mathrm{D}$ & White & $\mathrm{NJ}, 6^{\mathrm{th}}$ & 1 \\
\hline Ed Towns & $\mathrm{D}$ & African & $\mathrm{NY}, 10^{\text {th }}$ & 1 \\
\hline
\end{tabular}




\begin{tabular}{|c|c|c|c|c|}
\hline & & American & & \\
\hline Patrick Kennedy & $\mathrm{D}$ & White & $\mathrm{RI}, 1^{\mathrm{st}}$ & 1 \\
\hline Solomon Ortiz & $\mathrm{D}$ & Latino & $\mathrm{TX}, 27^{\text {th }}$ & 1 \\
\hline Henry Cuellar & $\mathrm{D}$ & Latino & $\mathrm{TX}, 28^{\text {th }}$ & 1 \\
\hline
\end{tabular}

Closed to Immigration Bill Sponsors

\begin{tabular}{|c|c|c|c|c|}
\hline Name & Party & Race & State & Total Sponsored \\
\hline Mo Brooks & $\mathrm{R}$ & White & $\mathrm{AL}, 5^{\text {th }}$ & 1 \\
\hline Paul Gosar & $\mathrm{R}$ & White & $\mathrm{AZ}, 1^{\mathrm{st}}$ & 1 \\
\hline Dana Rohrabacher & $\mathrm{R}$ & White & $\mathrm{CA}, 46^{\text {th }}$ & 1 \\
\hline Duncan Hunter & $\mathrm{R}$ & White & $\mathrm{CA}, 52^{\text {nd }}$ & 3 \\
\hline Steve King & $\mathrm{R}$ & White & $\mathrm{IA}, 5^{\text {th }}$ & 1 \\
\hline Charles Boustany & $\mathrm{R}$ & White & $\mathrm{LA}, 7^{\text {th }}$ & 1 \\
\hline Sue Myrick & $\mathrm{R}$ & White & $\mathrm{NC}, 9^{\text {th }}$ & 4 \\
\hline Heath Shuler & $\mathrm{D}$ & White & $\mathrm{NC}, 11^{\text {th }}$ & 2 \\
\hline Marsha Blackburn & $\mathrm{R}$ & White & $\mathrm{TN}, 7^{\text {th }}$ & 2 \\
\hline Ted Poe & $\mathrm{R}$ & White & $\mathrm{TX}, 2^{\text {nd }}$ & 2 \\
\hline Lamar Smith & $\mathrm{R}$ & White & $\mathrm{TX}, 21^{\mathrm{st}}$ & 2 \\
\hline John Shadegg & $\mathrm{R}$ & White & $\mathrm{AZ}, 3^{\text {rd }}$ & 1 \\
\hline Elton Gallegly & $\mathrm{R}$ & White & CA, $24^{\text {th }}$ & 4 \\
\hline Gary Miller & $\mathrm{R}$ & White & $\mathrm{CA}, 42^{\text {nd }}$ & 1 \\
\hline Darrell Issa & $\mathrm{R}$ & White & $\mathrm{CA}, 49^{\text {th }}$ & 2 \\
\hline Corrine Brown & $\mathrm{D}$ & African & FL, $3^{\text {rd }}$ & 1 \\
\hline
\end{tabular}




\begin{tabular}{|c|c|c|c|c|}
\hline & & American & & \\
\hline $\begin{array}{l}\text { Ginny Brown- } \\
\text { Waite }\end{array}$ & $\mathrm{R}$ & White & FL, $5^{\text {th }}$ & 1 \\
\hline Vern Buchanan & $\mathrm{R}$ & White & $\mathrm{FL}, 13^{\text {th }}$ & 1 \\
\hline Tim Mahoney & $\mathrm{D}$ & White & FL, $16^{\text {th }}$ & 1 \\
\hline Peter Roskam & $\mathrm{R}$ & White & $\mathrm{IL}, 6^{\text {th }}$ & 1 \\
\hline Mark Souder & $\mathrm{R}$ & White & $\mathrm{IN}, 3^{\text {rd }}$ & 1 \\
\hline Dan Burton & $\mathrm{R}$ & White & $\mathrm{IN}, 5^{\text {th }}$ & 1 \\
\hline Baron Hill & $\mathrm{D}$ & White & IN, $9^{\text {th }}$ & 1 \\
\hline Tom Latham & $\mathrm{R}$ & White & IA, $4^{\text {th }}$ & 1 \\
\hline $\begin{array}{l}\text { A. Dutch } \\
\text { Ruppersberger }\end{array}$ & $\mathrm{D}$ & White & $\mathrm{MD}, 2^{\text {nd }}$ & 1 \\
\hline James Oberstar & $\mathrm{D}$ & White & $\mathrm{MN}, 8^{\text {th }}$ & 1 \\
\hline Sam Graves & $\mathrm{R}$ & White & $\mathrm{MO}, 6^{\text {th }}$ & 2 \\
\hline Steve Pearce & $\mathrm{R}$ & White & $\mathrm{NM}, 2^{\text {nd }}$ & 1 \\
\hline Pete King & $\mathrm{R}$ & White & $\mathrm{NY}, 3^{\text {rd }}$ & 1 \\
\hline Nick Lampson & $\mathrm{D}$ & White & $T X, 22^{\text {nd }}$ & 1 \\
\hline Gene Green & D & White & $\mathrm{TX}, 29^{\text {th }}$ & 1 \\
\hline John Carter & $\mathrm{R}$ & White & $\mathrm{TX}, 31^{\mathrm{st}}$ & 1 \\
\hline Thelma Drake & $\mathrm{R}$ & White & $\mathrm{VA}, 2^{\text {nd }}$ & 1 \\
\hline Virgil Goode & $\mathrm{R}$ & White & $\mathrm{VA}, 5^{\text {th }}$ & 2 \\
\hline Ron Paul & $\mathrm{R}$ & White & $\mathrm{TX}, 14^{\text {th }}$ & 1 \\
\hline
\end{tabular}


Iraq Withdrawal Bill Sponsors

\begin{tabular}{|c|c|c|c|c|}
\hline Name & Party & Race & State & Total Sponsored \\
\hline Barbara Lee & $\mathrm{D}$ & $\begin{array}{l}\text { African } \\
\text { American }\end{array}$ & $\mathrm{CA}, 9^{\text {th }}$ & 4 \\
\hline Richard Nugent & $\mathrm{R}$ & White & $\mathrm{FL}, 5^{\text {th }}$ & 1 \\
\hline Mike Thompson & $\mathrm{D}$ & White & $\mathrm{CA}, 1^{\mathrm{st}}$ & 1 \\
\hline Lynn Woolsey & $\mathrm{D}$ & White & $\mathrm{CA}, 6^{\text {th }}$ & 2 \\
\hline Ellen Tauscher & $\mathrm{D}$ & White & $\mathrm{CA}, 10^{\text {th }}$ & 2 \\
\hline Sam Farr & $\mathrm{D}$ & White & $\mathrm{CA}, 7^{\text {th }}$ & 1 \\
\hline Howard Berman & $\mathrm{D}$ & White & $\mathrm{CA}, 28^{\text {th }}$ & 1 \\
\hline Maxine Waters & $\mathrm{D}$ & $\begin{array}{l}\text { African } \\
\text { American }\end{array}$ & $\mathrm{CA}, 35^{\text {th }}$ & 1 \\
\hline $\begin{array}{l}\text { Dana } \\
\text { Rohrabacher }\end{array}$ & $\mathrm{R}$ & White & $\mathrm{CA}, 46^{\text {th }}$ & 3 \\
\hline John Larson & $\mathrm{D}$ & White & $\mathrm{CT}, 1^{\mathrm{st}}$ & 1 \\
\hline Christopher Shays & $\mathrm{R}$ & White & $\mathrm{CT}, 4^{\text {th }}$ & 3 \\
\hline Robert Wexler & $\mathrm{D}$ & White & FL, $19^{\text {th }}$ & 1 \\
\hline Jesse Jackson & $\mathrm{D}$ & $\begin{array}{l}\text { African } \\
\text { American }\end{array}$ & $\mathrm{IL}, 2^{\text {nd }}$ & 1 \\
\hline Bruce Braley & $\mathrm{D}$ & White & IA, $1^{\text {st }}$ & 1 \\
\hline Wayne Gilchrest & $\mathrm{R}$ & White & $\mathrm{MD}, 1^{\mathrm{st}}$ & 1 \\
\hline Jim McGovern & $\mathrm{D}$ & White & $\mathrm{MA}, 3^{\text {rd }}$ & 2 \\
\hline Niki Tsongas & $\mathrm{D}$ & White & MA, $5^{\text {th }}$ & 1 \\
\hline
\end{tabular}




\begin{tabular}{|c|c|c|c|c|}
\hline Martin Meehan & $\mathrm{D}$ & White & $\mathrm{MA}, 5^{\text {th }}$ & 1 \\
\hline Ed Markey & $\mathrm{D}$ & White & MA, $7^{\text {th }}$ & 1 \\
\hline Bill Delahunt & $\mathrm{D}$ & White & $\mathrm{MA}, 10^{\text {th }}$ & 1 \\
\hline Mike Rogers & $\mathrm{R}$ & White & MI, $8^{\text {th }}$ & 1 \\
\hline John Dingell & $\mathrm{D}$ & White & MI, $15^{\text {th }}$ & 1 \\
\hline Keith Ellison & $\mathrm{D}$ & $\begin{array}{l}\text { African } \\
\text { American }\end{array}$ & $\mathrm{MN}, 5^{\text {th }}$ & 1 \\
\hline Ike Skelton & $\mathrm{D}$ & White & $\mathrm{MO}, 4^{\text {th }}$ & 2 \\
\hline Jeff Fortenberry & $\mathrm{R}$ & White & $\mathrm{NE}, 1^{\text {st }}$ & 1 \\
\hline Steve Israel & $\mathrm{D}$ & White & $\mathrm{NY}, 2^{\text {nd }}$ & 1 \\
\hline Jerrold Nadler & $\mathrm{D}$ & White & $\mathrm{NY}, 8^{\text {th }}$ & 1 \\
\hline Louise Slaughter & $\mathrm{D}$ & White & $\mathrm{NY}, 28^{\text {th }}$ & 4 \\
\hline David Price & $\mathrm{D}$ & White & $\mathrm{NC}, 4^{\text {th }}$ & 1 \\
\hline Dennis Kucinich & $\mathrm{D}$ & White & $\mathrm{OH}, 10^{\text {th }}$ & 2 \\
\hline Earl Blumenauer & $\mathrm{D}$ & White & $\mathrm{OR}, 3^{\text {rd }}$ & 1 \\
\hline Peter DeFazio & $\mathrm{D}$ & White & $\mathrm{OR}, 4^{\text {th }}$ & 1 \\
\hline Joe Sestak & $\mathrm{D}$ & White & PA, $7^{\text {th }}$ & 1 \\
\hline John Murtha & $\mathrm{D}$ & White & $\mathrm{PA}, 12^{\text {th }}$ & 1 \\
\hline Jim Langevin & $\mathrm{D}$ & White & RI, $2^{\text {nd }}$ & 1 \\
\hline John Tanner & $\mathrm{D}$ & White & $\mathrm{TN}, 8^{\text {th }}$ & 1 \\
\hline Ron Paul & $\mathrm{R}$ & White & $\mathrm{TX}, 14^{\text {th }}$ & 1 \\
\hline Adam Smith & $\mathrm{D}$ & White & WA, $9^{\text {th }}$ & 1 \\
\hline David Obey & $\mathrm{D}$ & White & WI, $7^{\text {th }}$ & 1 \\
\hline
\end{tabular}


APPENDIX G

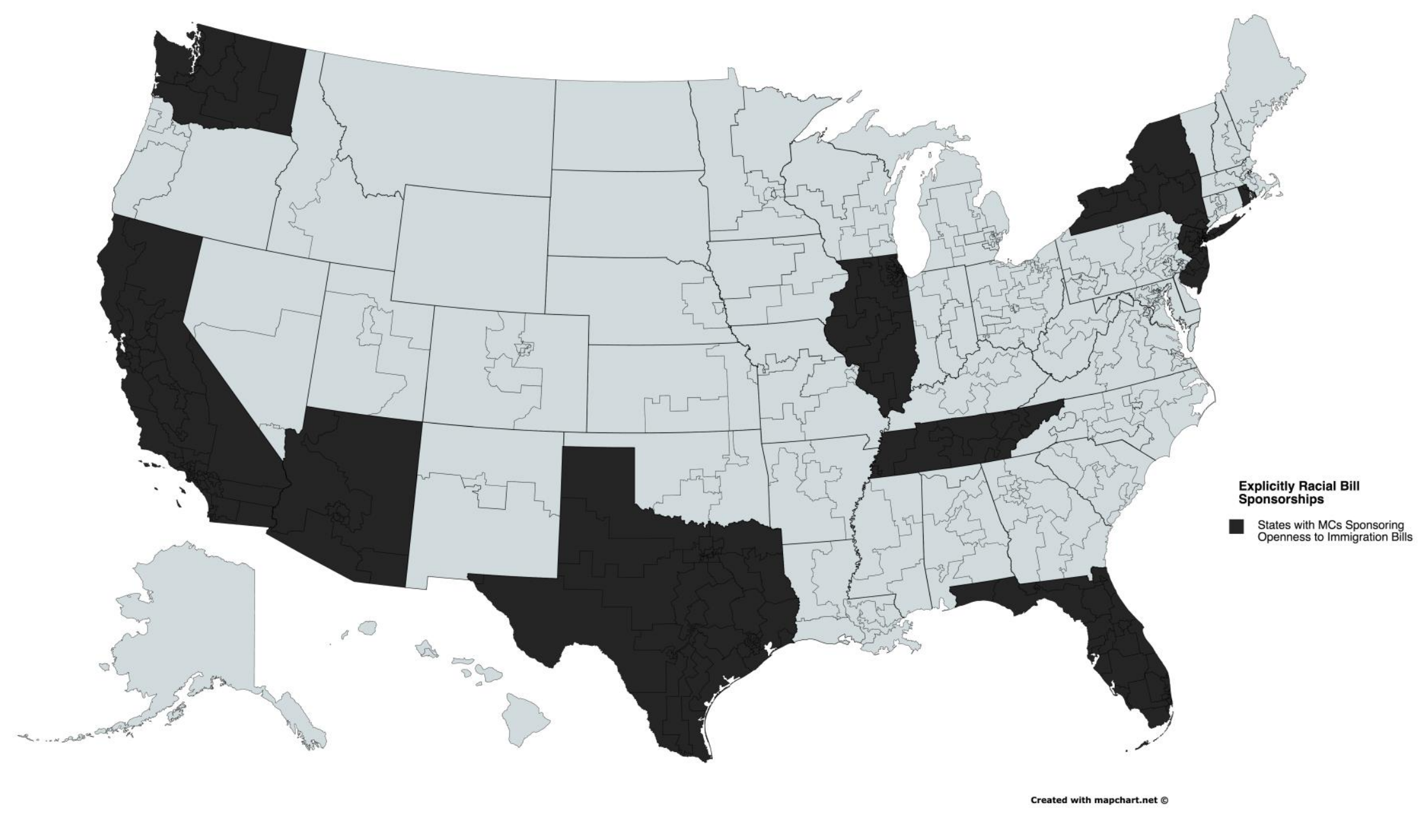




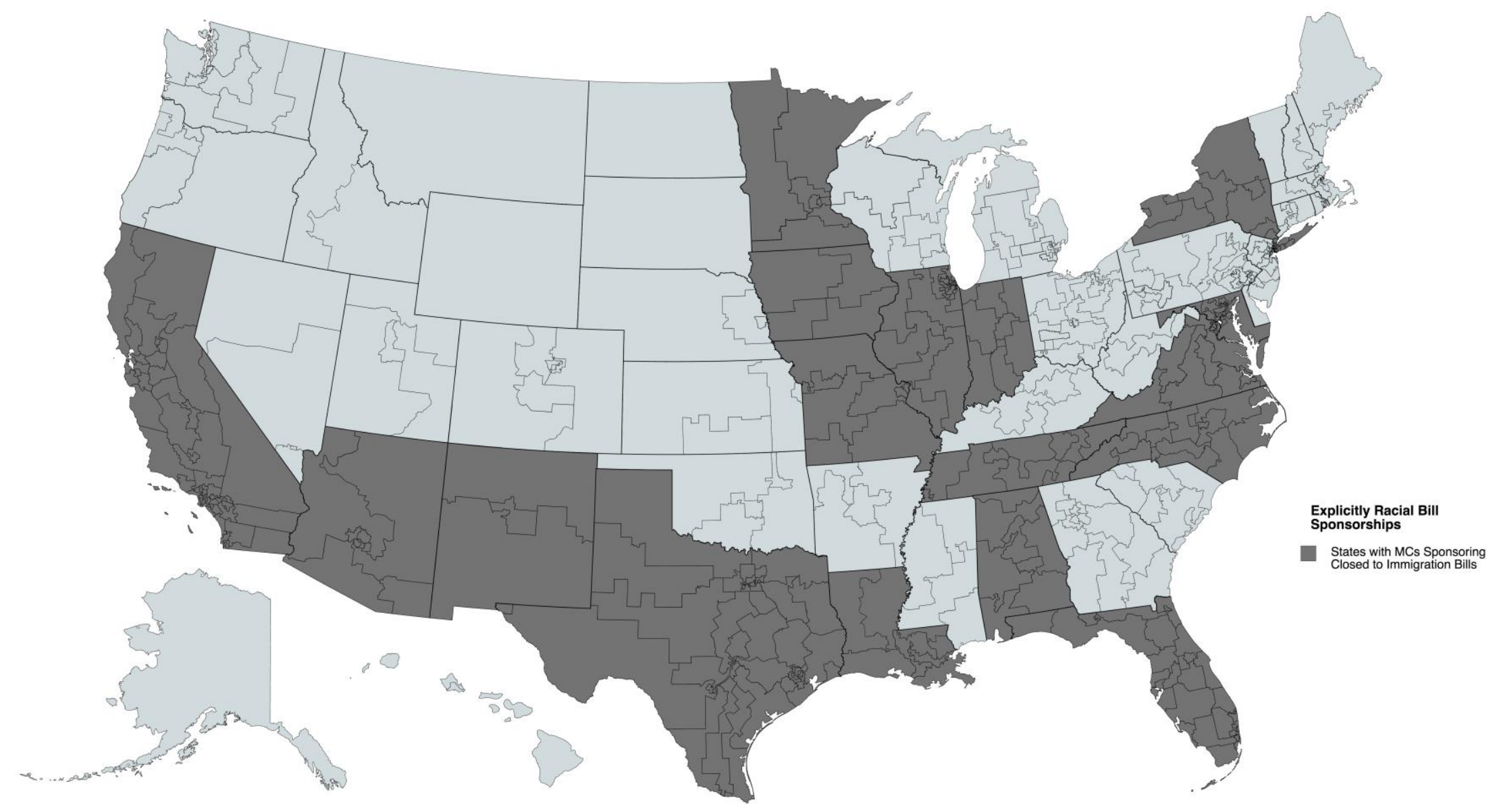




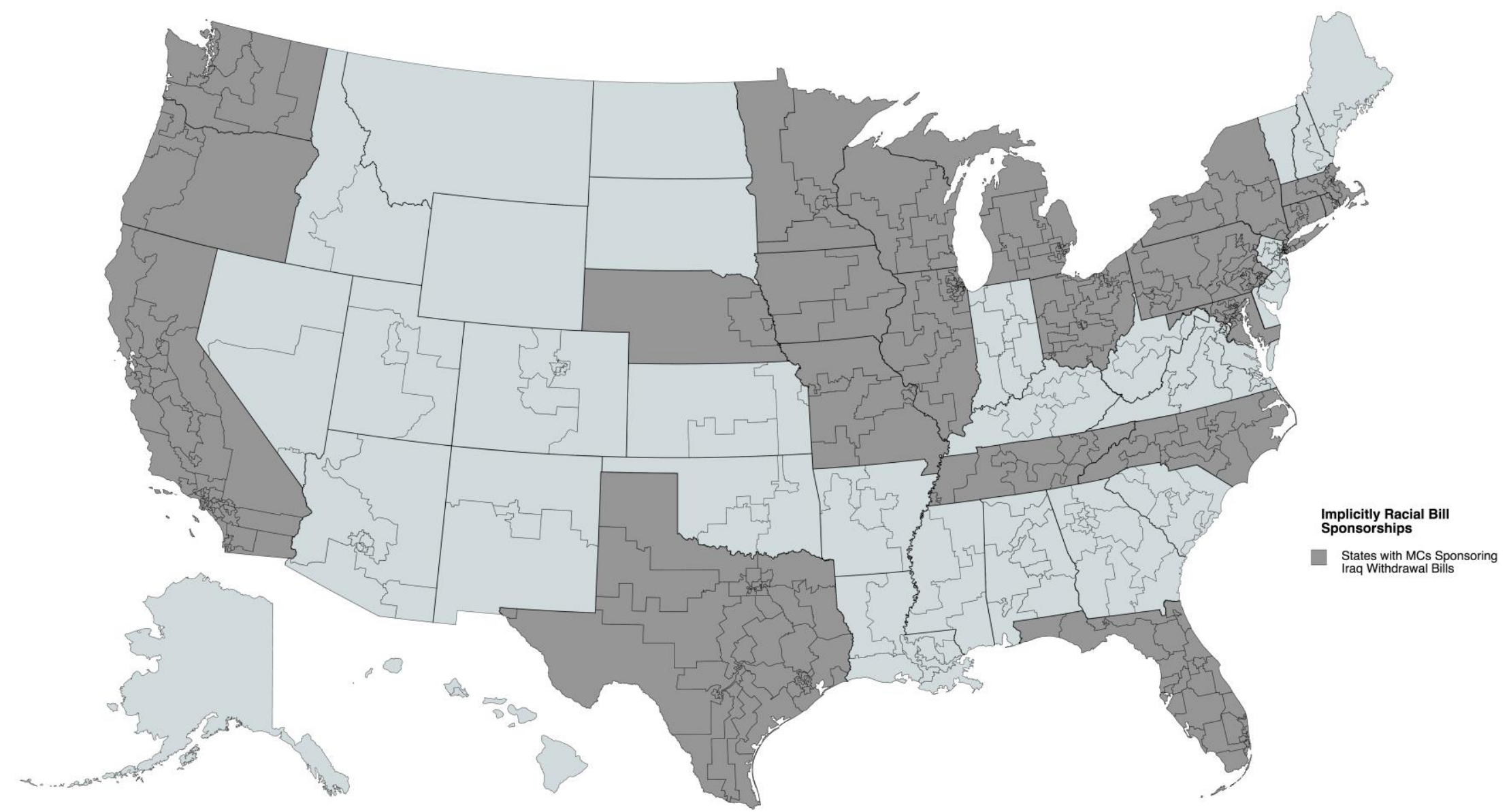




\section{APPENDIX H}

Impact of at Least One African American or Latino Member on Committees for Explicitly Racial Oversight, Logit Analysis

\begin{tabular}{|c|c|c|c|}
\hline Variables & $\begin{array}{l}\text { Full Model; } 80^{\text {th }}- \\
110^{\text {th }} \text { Congresses }\end{array}$ & $\begin{array}{l}80^{\text {th }}-102^{\text {nd }} \text { Congress } \\
\text { Model }\end{array}$ & $\begin{array}{l}103^{\text {rd }}-110^{\text {th }} \\
\text { Congress } \\
\text { Model }\end{array}$ \\
\hline $\begin{array}{c}\text { At least } 1 \text { African } \\
\text { American on } \\
\text { Committee }\end{array}$ & $\begin{array}{l}-0.6047 \\
(0.368)\end{array}$ & $\begin{array}{c}-0.4351 \\
(0.387)\end{array}$ & $\begin{array}{l}-1.731 \\
(1.612)\end{array}$ \\
\hline $\begin{array}{c}\text { At least } 1 \text { Latino on } \\
\text { Committee }\end{array}$ & $\begin{array}{c}0.312 \\
(0.363)\end{array}$ & $\begin{array}{l}0.2288 \\
(0.398)\end{array}$ & $\begin{array}{l}0.684 \\
(1.257)\end{array}$ \\
\hline $\begin{array}{c}\text { \% Minority } \\
\text { Members in } \\
\text { Congress }\end{array}$ & $\begin{array}{c}0.1262 * * \\
(0.045)\end{array}$ & $\begin{array}{l}0.0889 \\
(0.073)\end{array}$ & $\begin{array}{l}0.3301 \\
(0.373)\end{array}$ \\
\hline $\begin{array}{c}\text { African American } \\
\text { Chair }\end{array}$ & $\begin{array}{l}0.819 * \\
(0.406)\end{array}$ & $\begin{array}{l}0.8176 \\
(0.472)\end{array}$ & $\begin{array}{l}0.8578 \\
(0.895)\end{array}$ \\
\hline $\begin{array}{c}\text { Latino } \\
\text { Chair }\end{array}$ & $\begin{array}{c}1.3198 * * \\
(0.537)\end{array}$ & $\begin{array}{l}1.877 * * \\
(0.629)\end{array}$ & $\begin{array}{l}0.2166 \\
(1.270)\end{array}$ \\
\hline Constant & $\begin{array}{c}-3.04 * * * \\
(0.298)\end{array}$ & $\begin{array}{c}-2.94 * * * \\
(0.360)\end{array}$ & $\begin{array}{l}-5.16 \\
(4.909)\end{array}$ \\
\hline $\begin{array}{l}\text { Number of } \\
\text { observations }\end{array}$ & 538 & 493 & 45 \\
\hline Log-Likelihood & $-156.40 * * *$ & $-131.76^{* *}$ & -23.18 \\
\hline
\end{tabular}

Note: Democratically-led Houses only. The dependent variables are explicit and implicit hearings by committees (unit of analysis is the committee-Congress pair), where $0=$ no hearings and $1=1$ or more hearings. Entries are log odds; standard errors are in parentheses.

$* * *=\mathrm{p}<0.001 * *=\mathrm{p}<0.01 *=\mathrm{p}<0.05$ 


\section{APPENDIX I}

Racially Salient Oversight and Ideology, Logit Analysis

\begin{tabular}{|c|c|c|c|c|}
\hline Oversight Type & Variables & $\begin{array}{l}\text { Full Model; } \\
80^{\text {th }}-110^{\text {th }} \\
\text { Congresses }\end{array}$ & $\begin{array}{l}80^{\text {th }}-102^{\text {nd }} \\
\text { Congress } \\
\text { Model }\end{array}$ & $\begin{array}{l}103^{\text {rd }}-110^{\text {th }} \\
\text { Congress } \\
\text { Model }\end{array}$ \\
\hline \multirow[t]{7}{*}{ Explicit } & $\begin{array}{c}\text { \# African } \\
\text { Americans on } \\
\text { Committee }\end{array}$ & $\begin{array}{c}0.1460 * \\
(0.070)\end{array}$ & $\begin{array}{c}0.3088^{*} \\
(0.139)\end{array}$ & $\begin{array}{l}0.1019 \\
(0.084)\end{array}$ \\
\hline & $\begin{array}{c}\text { \# Latinos on } \\
\text { Committee }\end{array}$ & $\begin{array}{l}0.0610 \\
(0.097)\end{array}$ & $\begin{array}{l}0.1216 \\
(0.173)\end{array}$ & $\begin{array}{l}0.0037 \\
(0.122)\end{array}$ \\
\hline & $\begin{array}{l}\% \text { Minority } \\
\text { Members in } \\
\text { Congress }\end{array}$ & $\begin{array}{c}-0.05 \\
(0.038)\end{array}$ & $\begin{array}{l}0.0181 \\
(0.085)\end{array}$ & $\begin{array}{l}0.6380^{\wedge} \\
(0.338)\end{array}$ \\
\hline & $\begin{array}{l}\text { African } \\
\text { American } \\
\text { Chair }\end{array}$ & $\begin{array}{l}0.7729^{\wedge} \\
(0.398)\end{array}$ & $\begin{array}{c}0.3709 \\
(0.5104)\end{array}$ & $\begin{array}{l}0.4098 \\
(0.873)\end{array}$ \\
\hline & $\begin{array}{l}\text { Latino } \\
\text { Chair }\end{array}$ & $\begin{array}{c}2.0503 * * * \\
(0.545)\end{array}$ & $\begin{array}{c}2.4113 * * * \\
(0.673)\end{array}$ & $\begin{array}{l}0.0106 \\
(1.249)\end{array}$ \\
\hline & Ideology & $\begin{array}{c}7.8918^{* * * *} \\
(2.076) \\
\end{array}$ & $\begin{array}{c}15.3127 * * * \\
(3.867) \\
\end{array}$ & $\begin{array}{l}-0.384 \\
(6.083) \\
\end{array}$ \\
\hline & $\begin{array}{c}\text { Democratic } \\
\text { President }\end{array}$ & $\begin{array}{l}-0.2684 \\
(0.264)\end{array}$ & $\begin{array}{l}0.0091 \\
(0.411)\end{array}$ & $\begin{array}{l}0.1809 \\
(0.710)\end{array}$ \\
\hline \multirow[t]{7}{*}{ Implicit } & $\begin{array}{c}\text { \# African } \\
\text { Americans on } \\
\text { Committee }\end{array}$ & $\begin{array}{c}0.2388^{* * * *} \\
(0.057)\end{array}$ & $\begin{array}{l}0.0877 \\
(0.092)\end{array}$ & $\begin{array}{c}0.3932 * * * \\
(0.087)\end{array}$ \\
\hline & $\begin{array}{c}\text { \# Latinos on } \\
\text { Committee }\end{array}$ & $\begin{array}{l}-0.054 \\
(0.077)\end{array}$ & $\begin{array}{l}-0.2224 \\
(0.134)\end{array}$ & $\begin{array}{l}0.0192 \\
(0.104)\end{array}$ \\
\hline & $\begin{array}{c}\% \text { Minority } \\
\text { Members in } \\
\text { Congress }\end{array}$ & $\begin{array}{c}-0.063 * * \\
(0.027)\end{array}$ & $\begin{array}{l}0.0031 \\
(0.049)\end{array}$ & $\begin{array}{l}0.3824 \\
(0.285)\end{array}$ \\
\hline & $\begin{array}{l}\text { African } \\
\text { American } \\
\text { Chair }\end{array}$ & $\begin{array}{l}0.2256 \\
(0.296)\end{array}$ & $\begin{array}{l}0.3368 \\
(0.329)\end{array}$ & $\begin{array}{l}-0.6695 \\
(0.907)\end{array}$ \\
\hline & Latino Chair & $\begin{array}{c}1.3056^{* *} \\
(0.503)\end{array}$ & $\begin{array}{l}1.107^{\wedge} \\
(0.583)\end{array}$ & $\begin{array}{l}0.8382 \\
(1.258)\end{array}$ \\
\hline & Ideology & $\begin{array}{l}4.122 * * \\
(1.304)\end{array}$ & $\begin{array}{l}4.1725 \\
(2.239) \\
\end{array}$ & $\begin{array}{c}-2.1347 \\
5.042\end{array}$ \\
\hline & $\begin{array}{c}\text { Democratic } \\
\text { President }\end{array}$ & $\begin{array}{l}-0.099 \\
(0.172) \\
\end{array}$ & $\begin{array}{l}0.0989 \\
(0.225) \\
\end{array}$ & $\begin{array}{l}-0.5307 \\
(0.557) \\
\end{array}$ \\
\hline
\end{tabular}

Note: The dependent variables are explicit and implicit hearings by committees (unit of analysis is the committee-Congress pair), where $0=$ no hearings and $1=1$ or more hearings. Entries are log odds; standard errors are in parentheses. $* * *=p<0.001 * *=p<0.01 *=p<0.05^{\wedge}=p<0.06$ 
Racially Salient Oversight and Ideology, Negative Binomial Analysis

\begin{tabular}{|c|c|c|c|c|}
\hline Oversight Type & Variables & $\begin{array}{l}\text { Full Model; } \\
80^{\text {th }}-110^{\text {th }} \\
\text { Congresses }\end{array}$ & $\begin{array}{l}80^{\text {th }}-102^{\text {nd }} \\
\text { Congress } \\
\text { Model }\end{array}$ & $\begin{array}{l}103^{\text {rd }}-110^{\text {th }} \\
\text { Congress } \\
\text { Model }\end{array}$ \\
\hline \multirow[t]{7}{*}{ Explicit } & $\begin{array}{c}\text { \# African } \\
\text { Americans on } \\
\text { Committee }\end{array}$ & $\begin{array}{r}0.1412 \\
(0.078)\end{array}$ & $\begin{array}{c}0.2205 \\
(0.151)\end{array}$ & $\begin{array}{l}0.1131 \\
(0.088)\end{array}$ \\
\hline & $\begin{array}{c}\text { \# Latinos on } \\
\text { Committee }\end{array}$ & $\begin{array}{l}-0.0043 \\
(0.106)\end{array}$ & $\begin{array}{l}0.0466 \\
(0.209)\end{array}$ & $\begin{array}{l}-0.0947 \\
(0.117)\end{array}$ \\
\hline & $\begin{array}{l}\% \text { Minority } \\
\text { Members in } \\
\text { Congress }\end{array}$ & $\begin{array}{c}-0.0362 \\
(0.039)\end{array}$ & $\begin{array}{c}-0.0025 \\
(0.089)\end{array}$ & $\begin{array}{c}0.9985 * * \\
(0.356)\end{array}$ \\
\hline & $\begin{array}{c}\text { African } \\
\text { American } \\
\text { Chair } \\
\end{array}$ & $\begin{array}{c}0.8113 \\
(0.4108)\end{array}$ & $\begin{array}{c}0.5276 \\
(0.5266)\end{array}$ & $\begin{array}{l}0.1709 \\
(0.816)\end{array}$ \\
\hline & $\begin{array}{c}\text { Latino } \\
\text { Chair }\end{array}$ & $\begin{array}{l}1.6765^{*} \\
(0.669)\end{array}$ & $\begin{array}{l}2.040 * * \\
(0.812)\end{array}$ & $\begin{array}{l}-0.9626 \\
(1.421)\end{array}$ \\
\hline & Ideology & $\begin{array}{c}8.2041 * * * \\
(1.958)\end{array}$ & $\begin{array}{l}9.897 * * \\
(3.579)\end{array}$ & $\begin{array}{l}-0.9333 \\
(5.862)\end{array}$ \\
\hline & $\begin{array}{c}\text { Democratic } \\
\text { President }\end{array}$ & $\begin{array}{l}0.0138 \\
(0.278)\end{array}$ & $\begin{array}{l}0.5281 \\
(0.401)\end{array}$ & $\begin{array}{l}0.3443 \\
(0.731)\end{array}$ \\
\hline \multirow[t]{7}{*}{ Implicit } & $\begin{array}{c}\text { \# African } \\
\text { Americans on } \\
\text { Committee } \\
\end{array}$ & $\begin{array}{c}0.2486 * * * \\
(0.058)\end{array}$ & $\begin{array}{l}0.0578 \\
(0.099)\end{array}$ & $\begin{array}{c}0.4445 * * * \\
(0.086)\end{array}$ \\
\hline & $\begin{array}{c}\text { \# Latinos on } \\
\text { Committee }\end{array}$ & $\begin{array}{l}0.0365 \\
(0.088)\end{array}$ & $\begin{array}{l}-0.0408 \\
(0.156)\end{array}$ & $\begin{array}{l}0.1202 \\
(0.114)\end{array}$ \\
\hline & $\begin{array}{l}\% \text { Minority } \\
\text { Members in } \\
\text { Congress }\end{array}$ & $\begin{array}{l}-0.0449 \\
(0.028)\end{array}$ & $\begin{array}{l}0.0381 \\
(0.051)\end{array}$ & $\begin{array}{l}-0.019 \\
(0.246)\end{array}$ \\
\hline & $\begin{array}{c}\text { African } \\
\text { American } \\
\text { Chair }\end{array}$ & $\begin{array}{l}0.0482 \\
(0.308)\end{array}$ & $\begin{array}{l}0.1796 \\
(0.344)\end{array}$ & $\begin{array}{c}-1.1674 \\
(0.828)\end{array}$ \\
\hline & Latino Chair & $\begin{array}{c}1.7644 * * * \\
(0.498) \\
\end{array}$ & $\begin{array}{c}1.4124 * \\
(0.593)\end{array}$ & $\begin{array}{l}1.0005 \\
(0.985) \\
\end{array}$ \\
\hline & Ideology & $\begin{array}{c}3.6878 * * \\
(1.347) \\
\end{array}$ & $\begin{array}{c}5.4999 * \\
(2.243)\end{array}$ & $\begin{array}{l}0.5206 \\
(4.498)\end{array}$ \\
\hline & $\begin{array}{c}\text { Democratic } \\
\text { President }\end{array}$ & $\begin{array}{l}-0.2986 \\
(0.186)\end{array}$ & $\begin{array}{c}-0.141 \\
(0.247) \\
\end{array}$ & $\begin{array}{l}-0.8383 \\
(0.519)\end{array}$ \\
\hline
\end{tabular}

Note: The dependent variables are explicit and implicit hearing counts by committees (unit of analysis is the committee-Congress pair). Entries are logs of expected counts; standard errors are in parentheses.

$* * *=\mathrm{p}<0.001 * *=\mathrm{p}<0.01 *=\mathrm{p}<0.05$ 


\section{REFERENCES}

Adarand Constructors v. Pena. 1995. 515 U.S. 200.

"Affirmative Action." 2015. The Leadership Conference on Civil and Human Rights. http://www.civilrights.org. Accessed June 26, 2016.

Ansolabehere, Stephen, COOPERATIVE CONGRESSIONAL ELECTION STUDY, 2006--2012: COMMON CONTENT. [Computer file] Cambridge, MA: Harvard University [producer] http://cces.gov.harvard.edu.

Arizona v. U.S. 2012. 567 U.S.

Arnold, R. Douglas. 1990. The Logic of American Politics. New Haven: Yale University Press.

Banducci, Donovan, and J.A. Karp. 2004. "Minority Representation, Empowerment,and Participation." Journal of Politics 66(2): 534-556.

Barreto, Matt A., Gary M. Segura, and Nathan D. Woods. 2004. "The Mobilizing Effect of Majority-Minority Districts on Latino Turnout." American Review of Political Science 98(1): 65-75.

Baumgartner, Frank R., \& Jones, Bryan. D. 2010. Agendas and instability in American politics. University of Chicago Press.

Bobo, Lawrence, and Franklin D. Gilliam, Jr. 1990. "Race, Sociopolitical Participation, and Black Empowerment.” American Political Science Review 84(2): 377-393.

Bobo, Lawrence, and James R. Kluegel. 1993. "Opposition to Race-Targeting: Self Interest, Stratification Ideology, or Racial Attitudes?” American Sociological Review 58(4): 43-464. 
Bowleg, L. 2008. When Black+ lesbian+ woman $\neq$ Black lesbian woman: The methodological challenges of qualitative and quantitative intersectionality research. Sex roles, 59(5-6), 312-325.

Bowler, Shaun and Gary M. Segura. 2011. The Future is Ours: Minority Politics, Political Behavior, and the Multiracial Era of American Politics. Washington, DC: CQ Press.

“Budget Calls for Domestic Increase.” In CQ Almanac 2008, 64 ${ }^{\text {th }}$ ed., edited by Jan Austin, 4-7-4-10. Washington, D.C: Congressional Quarterly, 2009. http://library.cqpress.com/cqalmanac/cqual08-1090-52023-2174809.

Burwell v. Hobby Lobby Stores Inc. 2014. 573 U.S.

"Bush's Budget: Opening Salvo in Yearlong Struggle Over Spending." In CQ Almanac 2007, 63 ${ }^{\text {rd }}$ ed., edited by Jan Austin, 4-3-4-6. Washington D.C.: Congressional Quarterly, 2008.

http://library.cqpress.com/cqalmanac/cqual07-1006-449132047978.

“Central American Trade Accord Just Squeaks Through.” In CQ Almanac 2005, 61 ${ }^{\text {st }}$ ed., 17-3-17-5. Washington, D.C.:Congressional Quarterly, 2006. http://library.cqpress.com/cqalmanac/cqual05-766-20102-1042215.

City of Richmond v. Croson. 1989. 488 U.S. 469.

Cole, E. R. 2009. Intersectionality and research in psychology. American psychologist, 64(3), 170.

Congressional Budget Office. Report on the Troubled Asset Relief Program-October 2012. October 11, 2012. 
“Congress Clears $\$ 700$ Billion Bailout of Financial Services Industry."” In CQ Almanac 2008, 64 $4^{\text {th }}$ ed., edited by Jan Austin, 7-3-7-6. Washington, DC: Congressional Quarterly, 2009. http://library.cqpress.com/cqalmanac/cqual08-1090-52026 2174903.

Crano, William. 1997. "Vested Interest, Symbolic Politics, and Attitude-Behavior Consistency." Journal of Personality and Social Psychology 72(3): 485-491.

Dawson, Michael C. 1995. Behind the Mule: Race and Class in African-American Politics. Princeton, NJ: Princeton University Press.

"Debt Panel Report Fails to Reach Hill." In CQ Almanac 2010, 66 ${ }^{\text {th }}$ ed, edited by Jan Austin, 4-11-4-12. Washington, DC: CQ-RollCall Group, 2011. http://library.cqpress.com/cqalmanac/cqual10-1278-70358-2371567.

Denniston, Lyle. 2015. "New rules for ACA birth-control mandate." SCOTUSblog July 14 2015. http://www.scotusblog.com. Accessed June 27, 2016.

"Details of Mortgage Finance Bill." In CQ Almanac 2008, 64 $4^{\text {th }}$ ed., edited by Jan Austin, 7-13-7-17. Washington, D.C: Congressional Quarterly, 2009. http://library.cqpress.com/cqalmanac/cqual08-1090-52026-2174930.

Ellis, William Curtis, and Walter Clark Wilson. 2013. "Minority Chairs and Congressional Attention to Minority Issues: The Effect of Descriptive Representation in Positions of Institutional Power.” Social Science Quarterly 94.5 (December): 1207-1221.

“Employer Sanctions.” 2016. Federation for American Immigration Reform http://www.fairus.org/issue/employer-sanctions. Accessed July 3, 2016. 
Executive Order 13531. 2010. National Commission on Fiscal Responsibility and Reform. 75 FR 7927.

“Fact Sheet: Women's Preventive Services Coverage, Non-Profit Religious Organizations, and Closely-Held For-Profit Entities.” 2015. The Center for Consumer Information and Insurance Oversight, Centers for Medicare \& Medicaid Services. https://www.cms.gov/cciio/resources/fact-sheets-and-faqs/. Accessed June 27, 2016.

Fenno, Richard F. 1973. Congressmen in Committees. Boston: Little, Brown.

-. 1978. Home Style: House Members in Their Districts. Boston: Little, Brown.

Fisher v. University of Texas. 2013. 570 U.S.

Gale, William. 2016. “A Tax Even Conservatives Can Love.” U.S. News and World Report February 22, 2016.

Gay, Claudine. 2001. “The Effect of Black Congressional Representation on Political Participation." American Political Science Review 95(3): 589-602.

-. 2007. "Legislating Without Constraints: The Impact of Constituency Preferences on Policy Representation in Majority-Minority Districts.” Journal of Politics 69(2): 442-456.

Gilens, Martin. 2005. “Inequality and Democratic Responsiveness.” Public Opinion Quarterly 69.5:778-796

-. 2012. Affluence and influence: Economic inequality and political power in America. Princeton University Press. 
Griffin, John D., and Patrick Flavin. 2007. "Racial Differences in Information, Expectations, and Accountability." Journal of Politics 69(1): 220-236.

Griffin, John D., and B. Newman. 2007. “The Unequal Representation of Latinos and Whites." Journal of Politics 69(4): 1032-1046.

-. 2008. Minority report: Evaluating political equality in America. University of Chicago Press.

Grose, Christian R. 2011. Congress in Black and White: Race and Representation in Washington and at Home. New York: Cambridge University Press.

Gusmano, Michael. 2012. "Undocumented Immigrants in the United States: U.S. Health Policy and Access to Care," Undocumented Patients web site (Garrison, NY: The Hastings Center). http://www.undocumentedpatients.org/issuebrief/health-policy-and-access-to care/.

Hancock, A. M. 2007. When multiplication doesn't equal quick addition: Examining intersectionality as a research paradigm. Perspectives on politics, 5(01), 63-79.

Hawkesworth, M. 2006. Intersectionality. her Feminist Inquiry: From Political Conviction to Methodological Innovation, 207-248.

"Historical Financial Overhaul Creates Bureau, Expands Oversight of Banks." In $C Q$ Almanac 2010, 66 ${ }^{\text {th }}$ ed., edited by Jan Austin, 3-3-3-9. Washington, DC: CQ-Roll Call Group, 2011. http://library.cqpress.com/cqalmanac/cqual10-1278-70357 2371504. 
“House Adopts GOP Budget Plan.” In CQ Almanac 2011, 67"th ed., edited by Jan Austin, 3-9-3-10. Washington, DC: CQ-Roll Call Group, 2012. http://library.cqpress.com/cqalmanac/cqual-1390-77513-2462126.

Hopwood v. Texas. 1996. 518 U.S. 1016.

Jones, Bryan D. 1994. Reconceiving decision-making in democratic politics: Attention, choice, and public policy. University of Chicago Press.

-. 2001. Politics and the architecture of choice: Bounded rationality and governance. University of Chicago Press.

Jones, Jeffrey M. 2013. "In US, Most Reject Considering Race in College Admissions." http://www.gallup.com/poll/163655/reject-considering-race-college admissions.aspx. Accessed October 12, 2016.

"Kaiser Commission on Medicaid and the Uninsured." 2009. The Henry J. Kaiser Family Foundation Publication \#7743-02, www.kff.org.

Karon, Tony. 2011. “Iraq’s Government, Not Obama, Called Time on the U.S. Troop Presence.” Time Magazine, October 21, 2011. http://world.time.com/2011/10/21/iraq-not-obama-called-time-on-the-u-s-troop presence/. Accessed June 26, 2016.

Karpowitz, Christopher F.; Tali Mendelberg, and Lee Shaker. 2012. “Gender Inequality in Deliberative Participation.” American Political Science Review 106(3): 533 547.

Kastellec, Jonathan. 2013. Racial diversity and judicial influence on appellate courts. American Journal of Political Science, 57(1), 167-183.

Kaplan, Rebecca. 2015. “Is It Possible to End Birthright Citizenship?” CBS News. 
http://www.cbsnews.com/news/ending-birthright-citizenship. Accessed July 3, 2016.

Kim, Seung Min. 2013. “Senate Passes Immigration Bill.” Politico June 27, 2013.

Kinder, Donald R., and D. Roderick Kiewiet. 1979. "Economic Discontent and Political Behavior: The Role of Personal Grievances and Collective Economic Judgments in Congressional Voting.” American Journal of Political Science 23(3): 495-527.

Kinder, Donald R., and David O. Sears. 1981. "Prejudice and Politics: Symbolic Racism Versus Racial Threats to the Good Life." Journal of Personality and Social Psychology 40(3): 414-431.

Kinder, Donald R. and Nicholas Winter. 2001. "Exploring the Racial Divide: Blacks, Whites, and Opinion on National Policy." American Journal of Political Science 45(2): 439-456.

King, Desmond S., and Rogers M. Smith. 2005. "Racial Orders in American Political Development.” American Political Science Review 99(1): 75-92.

—. 2008. "Strange Bedfellows? Polarized Politics? The Quest for Racial Equity in Contemporary America." Political Research Quarterly 61(4): 686-703.

Kingdon, John W. 1977. "Models of Legislative Voting." The Journal of Politics 39(3): 565-595.

—. 1984. Agendas, Alternatives and Public Policies. Boston: Little, Brown.

Klein, Ezra. 2013. "Wonkbook: Everything You Need to Know about the Fiscal Cliff Deal.” The Washington Post, January 1, 2013.

Krogstad, Jens Manuel. 2015. “ $114^{\text {th }}$ Congress is Most Diverse Ever.” Pew Research Center, Washington D.C. 
Lau, Richard R., and Caroline Heldman. 2009. "Self-Interest, Symbolic Attitudes, and Support for Public Policy: A Multilevel Analysis.” Political Psychology 30(4): $513-537$.

Lederman, Josh. 2016. “Here is Obama’s Presidential Plan to Cut Gun Violence." PBS Newshour January 4, 2016.

Lederman, Josh. 2016 (2). "What You Need to Know About Obama’s Executive Actions on Gun Control.” PBS Newshour January 6, 2016.

Leighley, Jan E. and Arnold Vedlitz. 1999. "Race, Ethnicity, and Political Participation: Competing Models and Contrasting Explanations.” Journal of Politics 61(4): 1092-1114.

Liebelson, Dana. 2013. "Meet the 45 Senators Who Blocked Background Checks." Mother Jones April 17, 2013.

Lublin, David. 1997. The Paradox of Representation: Racial Gerrymandering and Minority Interests in Congress. Princeton, NJ: Princeton University Press.

Lublin, David and Stephen Voss. 2003. "The Missing Middle: Why Median-Voter Theory Can't Save Democrats from Singing the Boll-Weevil Blues.” Journal of Politics 65(1): 227-237.

Mansbridge, Jane. 1999. "Should Blacks Represent Blacks and Women Represent Women? A Conditional 'Yes.'” Journal of Politics 61(3): 628-657.

—. 2003. "Rethinking Representation." American Political Science Review 97(4): 515-528.

Mayhew, David. 1974. Congress: The electoral connection. Yale University Press. McClain, Paula D.; Carew, Jessica D. Johnson; Walton Jr., Eugene; and Candis S. Watts. 
2009. “Group Membership, Group Identity, and Group Consciousness: Measures of Racial Identity in American Politics?” Annual Review of Political Science 12(2009): 471-485.

Mendelberg, Tali. 2001. The Race Card: Campaign Strategy, Implicit Messages, and the Norm of Equality. Princeton University Press.

Meyers, Jordan. 2016. "Penalties for Hiring Illegal Workers." Small Business

Chronicle http://smallbusiness.chron.com/.

Miller v. Johnson. 515 US 900 (1995).

Miller, W. E., \& Stokes, D. E. 1963. Constituency influence in Congress. American political science review, 57(01), 45-56.

“Minimum Wage.” U.S. Department of Labor. https://www.dol.gov/general/topic/wages/minimumwage. Accessed October 26, 2016.

Minta, Michael. 2011. Oversight: Representing the interests of Blacks and Latinos in congress. Princeton University Press.

Minta, Michael and Valeria Sinclair-Chapman. 2013. Diversity in political institutions and congressional responsiveness to minority interests. Political Research Quarterly (66): 127.

Minta, Michael D., and Nadia E. Brown. 2014. "Intersecting Interests: Gender, Race, and Congressional Attention to Women's Issues.” Du Bois Review 11.2(2014): 253-272. 
"Mortgage Assistance Bill Signed." In CQ Almanac 2009, 65 $5^{\text {th }}$ ed., edited by Jan Austin, 3-9-3-10. Washington, DC: CQ-Roll Call Group, 2010. http://library.cqpress.com/cqalmanac/cqual09-1183-59534-2251213.

Murphy, Jan. 2014. "Poll Finds Support for More Money for Public Schools Despite Underestimating What is Already Spent.” PennLive August 26, 2014.

O’Connor, Linda, and Daniel Marans. 2016. “Here are 13 Examples of Donald Trump Being Racist.” Huffington Post. http://www.huffingtonpost.com/entry/donaldhttp://www.huffingtonpost.com/entry/donaldtrump-racist examples_us_56d47177e4b03260bf777e83. Accessed May 2, 2017.

Olivas, Michael A. 2010. "Plyler v. Doe: Still Guaranteeing Unauthorized Immigrant Children's Right to Attend U.S. Public Schools.” Migration Information Source migrationpolicy.org.

"On Views of Race and Inequality, Blacks and Whites Are Worlds Apart." 2016.

Pew Research Center, Washington D.C. (June 27, 2016).

"Options and Considerations for a Federal Carbon Tax." 2013. Center for Climate and Energy Solutions. http://www.c2es.org/publications. Accessed June 26, 2016.

Oremus, Will. 2015. “Obama's Climate Plan is Basically Cap and Trade.” Slate August 4, 2015.

Orey, B. D. A., Craemer, T., \& Price, M. 2013. Implicit Racial Attitude Measures in Black Samples: IAT,Subliminal Priming, and Implicit Black Identification. PS: Political Science \& Politics, 46(03), 550-552.

Partial-Birth Abortion Ban Act of 2003, Public Law 108-105, U.S. Statutes at Large 
117 Stat. 1201.

Peralta, Eyder. 2015. "3 Things You Should Know About Birthright Citizenship.” NPR August 18, 2015.

Plumer, Brad. 2013. "The U.S. Has Some of the Lowest Energy Taxes in the Developed World." The Washington Post January 31, 2013.

Plyler v. Doe. 1982. 457 U.S. 202.

"Politics and Elections Political Power Shift Dominates 2006, No Ordinary Election Year.” In CQ Almanac 2006, 62nd ed., edited by Jan Austin, 17-3-17-6. Washington, D.C.: Congressional Quarterly 2007. http://library.cqpress.com/cqalmanac/cqual06-1421295.

Rabinowitz, Joshua L., David O. Sears, Jim Sidanius, and Jon A. Kroznick. 2009. “Why Do White Americans oppose Race-Targeted Policies? Clarifying the Impact of Symbolic Racism.” Political Psychology, 30(5): 805-828.

Reeves, Keith. 1997. Voting Hopes or Fears?: White Voters, Black Candidates and Racial Politics in America. Oxford University Press.

Rohde, David W. 1991. Parties and Leaders in the Postreform House. Chicago: University of Chicago Press.

Russell Sage Foundation. "Economic Inequality and Political Representation." http://www.russellsage.org/research/data/economic-inequality-and-political representation. Accessed August 19, 2016.

Sanchez, Gabriel R. 2006. “The Role of Group Consciousness in Latino Public Opinion.” Political Research Quarterly 59(3): 435-446. 
Schickler, Eric; McGhee, Eric; and John Sides. 2003. "Remaking the House and Senate: Personal Power, Ideology, and the 1970s Reforms.” Legislative Studies Quarterly 28(3): 297-331.

Schickler, Eric, Kathryn Pearson and Brian D. Feinstein. 2010. “Congressional Parties and Civil Rights Politics from 1933 to 1972." Journal of Politics 72(3): 672-689.

Scott, Dylan. 2012. "Biggest Problem for Public Education? Lack of Funding, Poll Says." Governing August 23, 2012.

Sears, David O.; Hensler, Carl P.; and Leslie K. Speer. 1979. “Whites' Oppositiong to 'Busing:' Self-Interest or Symbolic Politics?” The American Political Science Review 73(2): 369-384.

Sears, David O.; Lau, Richard R.; Tyler, Tom R.; and Harris M. Allen. 1980. “Self Interest vs. Symbolic Politics in Policy Attitudes and Presidential Voting." The American Political Science Review 74(3): 670-684.

Sears, David, and Carolyn L. Funk. 1991. "The Role of Self-Interest in Social and Political Attitudes." In Advances in Experimental Social Psychology, Mark P. Zanna, Ed. Cambridge, Massachusetts: Academic Press.

“Senate Republicans Sink Climate Bill.” 2008. In CQ Almanac 2008, 64 ${ }^{\text {th }}$ ed., edited by Jan Austin, 8-6. Washington, D.C.: Congressional Quarterly, 2009. http://library.cqpress.com/cqalmanac/cqual08-1090-52027-2174968. Accessed June 26, 2016.

Shapiro, Ari. 2013. “Obama Warms to Speaking Personally About Race.” NPR. http://www.npr.org/sections/codeswitch/2013/08/03/208358153/has-obama changed-his-stance-on-speaking-about-race. Accessed May 1, 2017. 
Shaw v. Reno. 509 US 630 (1993).

Smith, Steven S., and Christopher J. Deering. 1984. Committees in Congress.Washington, D.C.: CQ Press.

Sobel, Laurie, Beamesderfer, Adara, and Alina Salganicoff. 2015. "Private Insurance Coverage of Contraception.” Kaiser Family Foundation July 9, 2015. http://kff.org. Accessed July 4, 2016.

Strolovitch, Dara Z. 2007. Affirmative Advocacy: Race, Class and Gender in Interest Group Politics.

Swain, Carol. 1995. Black faces, black interests: The representation of African Americans in Congress. Harvard University Press.

Tate, Katherine. 2003. Black Faces in the Mirror: African Americans and Their Representatives in the U.S. Congress. Princeton, NJ: Princeton University Press.

Tesler, Michael. 2010. Obama's Race: The 2008 Election and the Dream of a Post Racial America. Chicago: University of Chicago Press.

“The Dream Act.” 2010. White House Fact Sheet. https://www.whitehouse.gov/sites/default/files/DREAM-Act-WhiteHouse FactSheet.pdf. Accessed July 3, 2016.

United States v. Texas. 2016. 579 U.S.

U.S. Citizenship and Immigration Services. 2016. "Executive Actions on Immigration." https://www.uscis.gov/immigrationaction. Accessed July 3, 2016.

U.S. Congressional Research Service. "African American Members of the United States Congress: 1870-2008.” July 23, 2008. By Mildred L. Amer. 
U.S. Congressional Research Service. "Border Security: Immigration Enforcement Between Ports of Entry.” (R42138; April 19, 2016), by Carla N. Argueta.

U.S. Congressional Research Service. "Legislative Actions to Repeal, Defund, or Delay the Affordable Care Act.” (R43289; February 5, 2016), by C. Stephen Redhead and Janet Kinzer.

U.S. Congressional Research Service. "U.S.-Iraq Withdrawal Status of Forces Agreement: Issues for Congressional Oversight.” (R40011; July 13, 2009), by R. Chuck Mason.

U.S. Department of Health and Human Services. 2014. "Exemption and accommodations in connection with coverage of preventive health services," 45 CFR 147.131.

U.S. Environmental Protection Agency. 2015. "Carbon Pollution Emissions Guidelines for Existing Stationary Sources: Electric Utility Generating Units; Final Rule.” 40 CFR Part 60.

U.S. Environmental Protection Agency. 2016. "Clean Power Plan for Existing Power Plants.” https://www.epa.gov/cleanpowerplan. Accessed July 2, 2016.

U.S. Environmental Protection Agency Office of Atmospheric Programs. 2009. "EPA Analysis of the American Clean Energy and Security Act of 2009 H.R. 2454 in the $111^{\text {th }}$ Congress." www.epa.gov/climatechange/economics/economicanalyses.html.

Valentino, N. A., Hutchings, V. L., \& White, I. K. 2002. Cues that matter: How political ads prime racial attitudes during campaigns. American Political Science Review, 96(01), 75-90. 
Verba, Sidney; Kay Lehman Schlozman; and Henry E. Brady. 1995. Voice and Equality: Civic Voluntarism in American Politics. Cambridge, Mass: Harvard University Press.

Wadsworth, N. D. 2011. Intersectionality in California's same-sex marriage battles: A complex proposition. Political Research Quarterly, 64(1), 200-216.

Wasniewski, Matthew A., ed. 2013. "Hispanic Americans in Congress 1822-2012." Prepared Under the Direction of the Committee on House Administration of the U.S. House of Representatives, Daniel E. Lungren, chairman, Robert A. Brady, ranking minority member, by the Office of the Historian and Office of the Clerk, U.S. House of Representatives.

Weldon, S. Laurel. 2006. The structure of intersectionality: A comparative politics of gender. Politics \& Gender, 2(02), 235-248.

Wheaton College v. Burwell. 2015.

White, Ismail K. 2007. “When Race Matters and When It Doesn't: Racial Group Differences in Response to Racial Cues." American Political Science Review 101(2): 339-354.

Wilson, William Julius. 2012. The Declining Significance of Race: Blacks and Changing American Institutions. $3^{\text {rd }}$ ed. Chicago: University of Chicago Press. Winograd, Ben. 2012. “Q\&A Guide to Arizona v. United States.” Immigration Policy Center, American Immigration Council. https://americanimmigrationcouncil.org. Wolpert, Robin M., and James M. Gimpel. 1998. "Self-Interest, Symbolic Politics, and Public Attitudes Toward Gun Control." Political Behavior 20(3): 241-262. 
